VILNIAUS GEDIMINO TECHNIKOS UNIVERSITETAS

Vytautas PALEVIČIUS

\title{
LENGVŲJŲ AUTOMOBILIŲ STOVĖJIMO AIKŠTELIUৃ MIESTE VERTINIMAS DAUGIATIKSLIAIS METODAIS
}

DAKTARO DISERTACIJA

TECHNOLOGIJOS MOKSLAI, STATYBOS INŽINERIJA (02T) 
Disertacija rengta 2010-2014 metais Vilniaus Gedimino technikos universitete.

\section{Mokslinis vadovas}

prof. dr. Marija BURINSKIENÉ (Vilniaus Gedimino technikos universitetas, statybos inžinerija - 02T).

Vilniaus Gedimino technikos universiteto Statybos inžinerijos mokslo krypties disertacijos gynimo taryba:

\section{Pirmininkas}

prof. dr. Donatas ČYGAS (Vilniaus Gedimino technikos universitetas, statybos inžinerija - 02T).

\section{Nariai:}

dr. Raimondas BLIŪDŽIUS (Kauno technologijos universitetas, statybos inžinerija - 02T),

prof. habil. dr. Henrikas SIVILEVIČIUS (Vilniaus Gedimino technikos universitetas, transporto inžinerija - 03T),

prof. dr. Juris SMIRNOVS (Rygos technikos universitetas, statybos inžinerija $-02 \mathrm{~T})$,

prof. habil. dr. Leonas USTINOVIČIUS (Vilniaus Gedimino technikos universitetas, statybos inžinerija - 02T).

Disertacija bus ginama viešame Statybos inžinerijos mokslo krypties disertacijos gynimo tarybos posėdyje 2014 m. gruodžio 11 d. 10 val. Vilniaus Gedimino technikos universiteto senato posėdžių salèje.

Adresas: Saulètekio al. 11, LT-10223 Vilnius, Lietuva. Tel. (8 5) 274 4956; faks. (8 5) 270 0112; el. paštas doktor@vgtu.lt

Pranešimai apie numatomą ginti disertaciją išsiųsti $2014 \mathrm{~m}$. lapkričio $10 \mathrm{~d}$.

Disertaciją galima peržiūrèti interneto svetainèje http://dspace.vgtu.lt ir Vilniaus Gedimino technikos universiteto bibliotekoje (Saulètekio al. 14, LT-10223 Vilnius, Lietuva).

VGTU leidyklos TECHNIKA 2269-M mokslo literatūros knyga ISBN 978-609-457-725-3

(C) VGTU leidykla TECHNIKA, 2014

(C) Vytautas Palevičius, 2014

vytautas.palevicius@vgtu.lt 
VILNIUS GEDIMINAS TECHNICAL UNIVERSITY

Vytautas PALEVIČIUS

\section{EVALUATION OF CAR PARKING LOTS IN CITIES BY MULTICRITERIA METHODS}

DOCTORAL DISSERTATION

TECHNOLOGICAL SCIENCES,

CIVIL ENGINEERING (02T) 
Doctoral dissertation was prepared at Vilnius Gediminas Technical University in 2010-2014.

\section{Scientific Supervisor}

Prof Dr Marija BURINSKIENE (Vilnius Gediminas Technical University, Civil Engineering - 02T).

The Dissertation Defense Council of Scientific Field of Civil Engineering of Vilnius Gediminas Technical University:

\section{Chairman}

Prof Dr Donatas ČYGAS (Vilnius Gediminas Technical University, Civil Engineering - 02T).

\section{Members:}

Dr Raimondas BLIŪDŽIUS (Kaunas University of technology, Civil Engineering - 02T),

Prof Dr Habil Henrikas SIVILEVIČIUS (Vilnius Gediminas Technical University, Transport Engineering - 03T),

Prof Dr Juris SMIRNOVS (Riga Technical University, Civil Engineering 02T),

Prof Dr Habil Leonas USTINOVIČIUS (Vilnius Gediminas Technical University, Civil Engineering - 02T).

The dissertation will be defended at the public meeting of the Dissertation Defense Council of Civil Engineering in the Senate Hall of Vilnius Gediminas Technical University at 10 a. m. on 11 December 2014.

Address: Saulètekio al. 11, LT-10223 Vilnius, Lithuania.

Tel.: +370 5274 4956; fax: +370 5270 0112; e-mail: doktor@vgtu.lt

A notification on the intend defending of the dissertation was send on 10 November 2014.

A copy of the doctoral dissertation is available for review at the internet website http://dspace.vgtu.lt and at the Library of Vilnius Gediminas Technical University (Saulètekio al. 14, LT-10223 Vilnius, Lithuania). 


\section{Reziumè}

Disertacijoje atliekama automobilių stovejjimo vietų poreikio mieste analizè. Pagrindinis darbo objektas - asmeninių kelionių automobilių stovejjimo vietu didmiestyje pasiskirstymo sistema. Ekspertiniu metodu sudaryta automobiliu stovejjimo vietų mieste kriterijų sistema. Taikant daugiatikslius metodus kriterijams suteikti rangai ir apskaičiuoti jų svorių koeficientai, kurie leido nustatyti kriterijų prioritetus ir parinkti racionaliausias automobilių stovejjimo aikštelių išdėstymo vietas miesto teritorijoje. Pagrindinis darbo tikslas pasiūlyti automobiliu stovejjimo vietų mieste plètros vertinimo modelị ir pateikti originalius automobilių stovèjimo aikštelių plètros koncepcinius sprendinius.

Disertaciją sudaro įvadas, 3 skyriai, bendrosios išvados, literatūros sąrašas, publikacijų sąrašas.

Ivade trumpai aptariama tiriamoji problema, darbo aktualumas, aprašomas tyrimo objektas, formuluojamas darbo tikslas ir uždaviniai, aprašoma mokslinis darbo naujumas, ginamieji teiginiai. İvado pabaigoje pristatomos autoriaus paskelbtos publikacijos, pranešimai konferencijose, nurodomas dalyvavimas tarptautiniuose seminaruose ir pateikiama disertacijos struktūra.

Pirmame skyriuje pateikiama mokslinès literatūros ir kitų atliktų darbų analizè nagrinejama tematika. Taip pat atlikta Lietuvos Respublikos, Europos Sajungos ir kitų pasaulio šalių norminių dokumentų, reglamentuojančių lengvųjų automobilių stovejimą skirtingose miesto teritorijose, analizè.

Antrajame skyriuje atliekamas automobilių stovejjimo vietų tyrimas daugiabučiu namų gyvenamuosiuose rajonuose ir prekybos centrų automobiliu stovèjimo aikštelèse. Nustatyta automobilių stovëjimo vietų mieste kriteriju sistema ir suskaičiuoti jų svoriai. Pasiūlytos statyk ir važiuok sistemos koncepcijos ir teorinis modelis.

Trečiajame skyriuje, taikant daugiatikslius metodus, sukurta prekybos centrų automobilių stovėjimo aikštelių vertinimo sistema, pasiūlyta statyk ir važiuok sistemos automobilių stovėjimo aikštelių mieste sisteminės atrankos strategija ir sudaryti trys originalūs automobilių stovèjimo aikštelių koncepciniai modeliai, kurie pritaikyti realiai didmiesčio erdvei.

Disertacijos tema paskelbta penkios mokslinès publikacijos, iš kurių dvi referuojamos duomenų bazès Thomson Reuters Web of Knowledge (ISI Web of Science) recenzuojamuose mokslo žurnaluose, dvi publikacijos pristatytos recenzuojamose tarptautinèse mokslo konferencijose ir viena publikacija kitame recenzuojamame mokslo žurnale. 


\section{Abstract}

This dissertation examines the shortage of motor vehicle parking spaces in the city area. The object of this research is the allocation of passenger car parking spaces in cities. A criteria system for car parking spaces in cities was formed using the expert estimate method. By using multi-criteria methods, the criteria were grouped and their factor value was calculated, which helped to establish the priorities of the criteria and to determine the most rational places for parking lots in the city area. This research aims to suggest a model for developing an infrastructure of car parking spaces in the city and to present original conceptual solutions for the expansion of parking lots.

The dissertation comprises an introduction, three chapters, general conclusions, a list of literature, and a list of publications.

The introduction specifies the problem, describes the relevance of the paper, names the research object, the aim and objectives, its scientific novelty, and the defended statements. Finally, it lists publications and conference presentations of the author, describes the author's participation in international seminars and presents the structure of the dissertation.

Chapter one introduces the literature overview of the subject analysis and discusses the study of the scientific research carried out in this field. It also presents the examination of the normative documents in Lithuania, the European Union and in other countries, which regulate motor car parking in different areas of the town.

Chapter two discusses the investigation of car parking spaces in residential areas and in shopping center parking lots. The criteria system for car parking spaces in the city is established and its value is counted. Moreover, the concept and the theoretical model of the park and ride system are suggested.

Chapter three examines the evaluation system of shopping mall parking lots by incorporating multi-criteria methods; the strategy for systematical selection of park and ride car parking system in the city is suggested; three original conceptual parking lot models, which are applicable to the real city area, are created.

Five scientific publications are announced on the topic of this dissertation out of which: two are referred by the Thomson Reuters Web of Knowledge (ISI Web of Science) database and reviewed in scientific journals; two publications are presented in international conferences and one publication appears in another peer reviewed scientific journal. 


\section{Žymèjimai}

\section{Simboliai}

$p_{i j}$ - kriterijų nežinomųjų svorių santykiai;

$m$ - lyginamų kriterijų skaičius;

$S_{I}$ - suderinamumo indeksas;

$S$ - suderinamumo santykis;

$S_{A}$ - sugeneruotos (pagal skalę 1-3-5-7-9) suderinamumo indeksas;

$P$ - porinio lyginimo matrica;

$\lambda_{\max }-$ matricos tikrinè reikšmé;

$r$ - ekspertų skaičius;

$\omega_{i}-i$-jo rodiklio $k$-jo eksperto suskaičiuoti svoriai;

$W$ - konkordacijos koeficientas;

$\chi^{2}$ - konkordancijos koeficiento reikšmingumas;

$v$ - laisvès laipsnis;

$\alpha$ - reikšmingumo lygmuo;

$\bar{e}$ - bendras rangų vidurkis;

$\chi_{k r}^{2}$ - konkordancijos koeficiento kritinè reikšmè;

$p_{s t}$ - stovinčių aikštelèje automobiliu skaičius;

$a$ - esamas automobiliu stovèjimo vietu skaičius;

$l$ - laisvų automobilių stovèjimo vietų skaičius;

$n$-neleistinai stovinčių automobilių skaičius;

$k$ - automobilių stovejimo aikštelès užpildymo (užimtumo) koeficientas; 
$c_{i k}$ - tiesiogiai procentais ịvertino kiekvieno kriterijaus reikšmingumas;

$r_{i j}-i$-jo kriterijaus reikšmé $j$-jo sprendimo alternatyvos variantu;

$n$ - lyginamujų variantų skaičius;

$S_{-j}$ - minimizuojančių ịvertintų normalizuotų kriterijų suma;

$S_{+j}$ - maksimizuojančių ịvertintų normalizuotų kriterijų suma;

$Q_{j}$ - santykinis reikšmingumas;

$N_{j}$ - naudingumo laipsnis;

$m_{i j}-i$-ojo kriterijaus vieta $j$-jam objektui;

$V_{j}$ - vietų sumos kriterijaus reikšmé;

$\widetilde{r}_{i j}-i$-ojo kriterijaus normalizuota reikšmè $j$-jam objektui;

$S_{j}$ - SAW metodo pasvertujų kriterijų reikšmių suma;

$I_{1}$ - maksimizuojamujų rodiklių indeksų aibé;

$I_{2}$ - minimizuojamujjų rodiklių indeksų aibė;

$D_{j}^{*}$ - TOPSIS metodu skaičiuojamas kiekvieno lyginamo varianto bendras atstumas iki geriausių sprendinių;

$D_{j}^{-}$- TOPSIS metodu skaičiuojamas kiekvieno lyginamo varianto bendras atstumas iki blogiausių sprendinių;

$C_{j}^{*}$ - TOPSIS metodu skaičiuojamas kriterijus;

$\pi\left(A_{j}, A_{k}\right)$ - skaičiuojamas rangavimo santykis;

$p_{t}(d)-t$-ja prioritetų funkcija, pasirinktoji i-jam kriterijui;

$F_{j}^{+}-j$-os alternatyvos visų ,išeinančių“ santykių suma;

$F_{j}^{-}-j$-os alternatyvos visų , ,einančių“" santykių suma;

$F_{j}-j$-os alternatyvos visų santykių skirtumų suma;

$P C_{p}$ - prekybos centro plotas;

$P C_{v}$ - prekybos centro automobilių stovejjimo aikštelèje vietų skaičius;

$U I$ - užstatymo intensyvumas;

$D G_{s}$ - dirbančiujų gyventojų skaičius;

$B_{s}$ - butų skaičius;

$P C_{k}$ - automobilių stovèjimo aikštelių užpildymo koeficientas;

$P C_{r}$ - automobilių stovejjimo vietos, vienam butui, mažinimo procentas.

$K_{j}$ - LTC kokybès indeksas;

$J$ - LTC skaičius mieste $(j=1,2, \ldots, J)$;

$I$ - ASA skaičius j-ame maršrute, t. y. LTC $(i=1,2, \ldots, I)$; 
$K$ - ASA skaičius mieste, t. y. visuose LTC $(k=1,2, \ldots, K), K=\sum_{j=1}^{J} I_{j}$;

$R$ - ASA rangas, nustaytas ekspertų daugiatiksliais metodais (visų ASA rangų skaičius

$K$, o visų ASA rangų suma $\left.R_{i j}=R_{1}+R_{2}+\ldots+R_{K}\right)$;

$R_{i j}-i$-ojo LTC $i$-osios ASA rangas $(i=1,2, \ldots, I ; j=1,2, \ldots, J)$;

$A_{i j}-$ ASA plotas;

$L_{i j}-j$-ojo LTC $i$-ojo ruožo (magistralinès ịvažiavimo ì miestą gatvès) ilgis nuo ASA sankirtos su LTC iki miesto centro;

$l_{i j}$ - atstumas nuo ASA iki LTC;

$P_{1}$ - vietų skaičius nemotorizuoto TP stovejjimo zonoje;

$D_{e}$ ir $D_{p}$ - esamas ir prognozuojamas dviračių skaičius piko avalandą ties ASA;

$\beta$-skaičiuojamas dviračių skaičius pirmaisiais metais.

\section{Santrumpos}

AHP - analitinio hierarchinio proceso metodas;

ASA - automobilių stovejjimo aikštele;

ASV - automobilių stovèjimo vieta;

$\mathrm{BP}$ - bendrasis planas;

COPRAS - daugiakriterinio kompleksinio proporcingumo metodas (angl. Complex

Proportional Assessment of Alternatives);

EK - Europos komisija;

ES - Europos Sajunga;

ESV - elektromobilių stovejjimo vieta;

GIS - geografinès informacinès sistemos;

JT - Jungtinès Tautos;

KASKO - sausumos transporto priemonių, išskyrus geležinkelių transporto priemones, draudimas;

KET - kelių eismo taisyklès;

KTKS - kombinuota transporto kelionių sistema;

LA - (lengvasis) automobilis;

LR - Lietuvos Respublika;

LTC - linijinis traukos objektas;

$\mathrm{PC}$ - prekybos centras;

PROMETHEE - prioritetiškumo funkcijų taikymas (angl. Preference Ranking

Organisation Method for Enrichment Evaluation); 
$\mathrm{R}$ - spindulys (300 metrų spindulys nuo prekybos centro automobilių stovèjimo aikštelès, kurio ribose atliekami tyrimai);

SAW - paprastojo svorių sudèjimo metodas (angl. Simple Additive Weighting);

SI - savivaldybès įmoné;

$\mathrm{SP}$ - specialusis planas;

SS - susisiekimo sistema;

STR - statybos techninis reglamentas;

SV - Statyk ir važiuok sistema;

TOPSIS - artumo idealiam taškui metodas (angl. Technique for Order Preference by Similiarity to Ideal Solution);

UAB - uždara akcinè bendrové;

VGTU - Vilniaus Gedimino technikos universitetas;

$\mathrm{VI}$ - viešoji įstaiga;

VS - vietų sumą;

VT - viešasis transportas.

\section{Terminai ir apibrèžimai}

Automatizuota požeminė automobilių stovèjimo aikštelė - patalpa arba pastatas transporto priemonèms laikyti po žeme, kurioje automobiliai pastatomi ị stovejjimo vietą ir valdomi programine ịranga.

Automobilių stovẻjimo aikštelė - trumpalaikiams ar ilgalaikiams automobilių stovèjimui pritaikyta teritorija, pažymèta atitinkamais kelio ženklais ar ženklinimu. Stovejjimo aikštelès gali būti mokamos arba nemokamos, privačios arba priklausančios savivaldybèms.

Automobilių stovẻjimo vieta - trumpalaikiams ar ilgalaikiams automobilių stovejimui pritaikyta vieta, kurios matmenys 2,5 x 5,0 metrų. Stovejjimo vietos dažniausiai įrengtos automobilių stovèjimo aikštelèje, tačiau jos gali būti ịrengtos gatvèje ar specialioje irrengtoje stovèjimo juostoje.

Automobilių stovèjimo vietos funkcionavimo kokybė - vienos automobilio stovėjimo vietos maksimalus automobilių skaičiaus panaudojimas per tam tikrą laiko vienetą.

Biotransporto priemonè - transporto priemonè, kuri beveik neteršia aplinkos ir atitinka aplinkos apsaugai keliamus reikalavimus.

Centrinė miesto zona - miesto dalis, esanti miesto centre.

Daugiaaukštẻ automobilių stovèjimo aikštelè - dviejų ir daugiau aukštų patalpa arba pastatas transporto priemonèms laikyti.

Dominuojanti originali viešojo transporto keleivių susisiekimo sistema - pagrindinès miesto transporto priemonès, galinčios pervežti didelį kiekị žmonių per trumpą laiką.

Efektyvumas - rezultato ir panaudotų išteklių santykis. 
Ekspertas - mokslo, meno ar kitų sričiu specialistas, kviečiamas atsakyti ị klausimus, reikalaujančius specialių žinių.

Ilgalaikis automobilio stovẻjimo vieta - automobilio stovèjimas nuolatinèje jam skirtoje vietoje nakčiai, žiemos sezonui ar kai sugenda.

Trumpalaikis automobilio stovèjimo vieta - laikina automobilio stovèjimo vieta atvykus ị darbovietę, lankantis ịvairiose viešose vietose, buities ar kultūininès paskirties ịstaigose, atvykus ị svečius.

Keleivių išlaipinimo ir ịlaipinimo zona - Statyk ir važiuok automobilių stovèjimo aikštelëje išskirta sustojimo vieta, kurioje automobilio vairuotojas per trumpą laiką išlaipina arba ịlaipina keleivị.

Kombinuota transporto kelioniụ sistema - integruota kelionių visuma, pervežant keleivius ne mažiau kaip dvejomis transporto rūšimis.

Liftinė automobilių stovẻjimo aikštelè - dviejų ir daugiau aukštų liftinės konstrukcijos statinys transporto priemonèms laikyti.

Modulinių konstrukcijų automobilių stovẻjimo aikštelè - sukonstruota automobilių stovejimo aikštelè, kuri surinkta iš modulinių konstrukcijų.

Požeminė automobiliụ stovẻjimo aikštelė - patalpa arba pastatas transporto priemonèms laikyti po žeme.

Priemiestinè miesto zona - miesto teritorijos, labiausiai nutolusios nuo miesto centro.

Rangas - hierarchijos lygmuo hierarchinèje sistemoje, kurios elementus galima sudèti vienus su kitais ir dauginti iš skaičių: tarpusavyje tiesiškai nepriklausomų elementų skaičiaus.

Respondentas - asmuo, atsakinėjantis ị socialinių tyrimų anketas arba tyrëjo žodžiu užduodamus klausimus.

Sistema - tam tikra tvarka sujungtų komponentų visuma.

Statyk ir važiuok autobusas - autobusas, kuris perveža keleivius iš statyk ir važiuok automobilių stovejjimo aikštelès iki tam tikros miesto teritorijos.

Statyk ir važiuok sistema - susisiekimo sistema, kai asmeninè transporto priemonè yra paliekama specialioje automobilių stovejjimo aikšstelëje miesto prieigose ir tolimesné kelionè tęsiama viešuoju transportu arba specialiu autobusu.

Užstatymo intensyvumas - visų pastatų antžeminès dalies patalpų bendrojo ploto sumos santykis su žemès sklypo plotu.

Vidurinė miesto zona - miesto dalis, esanti tarp miesto centro ir priemiestinès zonos.

Viešojo transporto stotelė - tai speciali įrengta vieta keleiviams išlipti iš viešojo transporto ir ilipti i jij. 



\section{Turinys}

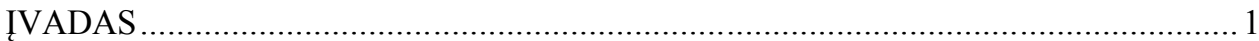

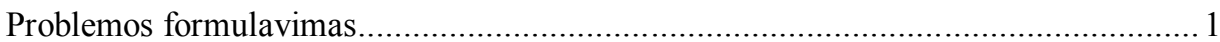

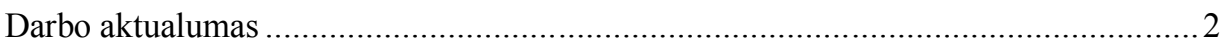

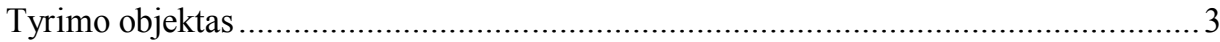

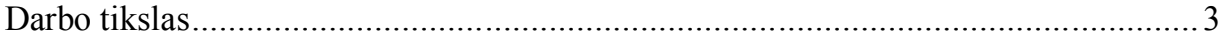

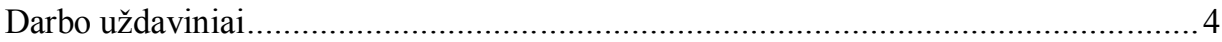

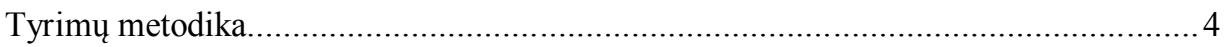

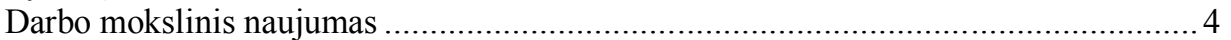

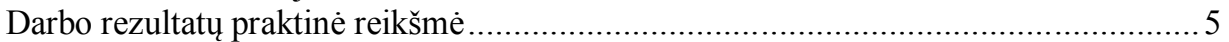

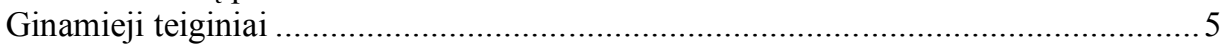

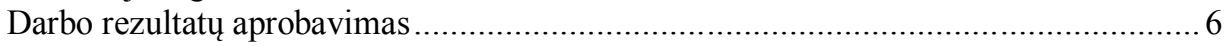

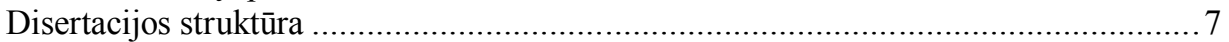

1. MOKSLO DARBŲ, SKIRTŲ AUTOMOBILIŲ STOVĖJIMO VIETŲ MIESTUOSE

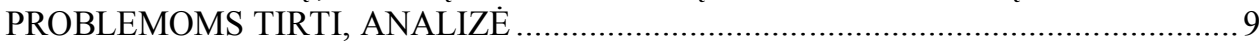

1.1. Automobilių stovejjimo problemos kilmè ir jos atsiradimo priežastys ...................9

1.2. Automobilių stovejjimo vietų išsidèstymo sistema mieste.................................. 12

1.2.1. Automobilių stovejjimo vietų poreikis ir galimybės centrinèse miestų zonose: senamiestyje ir miesto centre .................................................. 13

1.2.2. Automobilių stovéjimo vietos vidurinèse miestų zonose........................... 19

1.2.3. Automobilių stovèjimo vietos priemiestinèse miestų zonose .......................25

1.3. Kiti automobilių panaudojimo ir stovèjimo vietų mažinimo būdai ....................... 30 
1.4. Inovatyvūs ir modernūs technologiniai automobilių stovèjimo statiniai.............. 32

1.5. Automobilizacijos lygio raida Lietuvos miestuose..................................... 34

1.6. Norminių aktų, reglamentuojančių automobilių statymą, apžvalga..................... 36

1.7. Pirmojo skyriaus išvados ir disertacijos uždavinių formulavimas ...................... 40

2. AUTOMOBILIŲ STOVE்JIMO VIETŲ TEORINIAI TYRIMAI IR ANALIZE் ........ 43

2.1. Automobilių stovèjimo vietų tyrimo planas ir metodika................................ 43

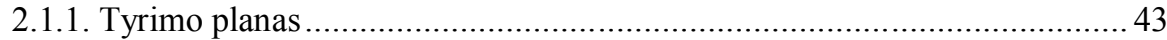

2.1.2. Stovinčių automobilių kiekio tyrimo metodai...................................... 45

2.2. Automobilių stovejjimo vietų tyrimų seka ir rezultatai.................................. 47

2.2.1. Automobilių stovejjimo tyrimų rezultatai daugiabučių namų gyvenamuosiuose rajonuose .................................................... 48

2.2.2. Gyvenamųjų rajonų automobilių stovejjimo aikštelių kiekybinių kriterijų svarbos tyrimas AHP metodu ....................................................... 49

2.2.3. Automobilių stovejjimo tyrimų rezultatai prekybos centrų automobilių stovèjimo aikštelèse ............................................................... 55

2.2.4. Prekybos centrų automobilių stovėjimo aikštelių parametrų svarbos tyrimas AHP metodu.................................................................. 59

2.2.5. Statyk ir važiuok aikštelių plètros strategija Vilniaus mieste..................... 63

2.2.6. Statyk ir važiuok sistemos automobilių stovėjimo aikštelių rodiklių

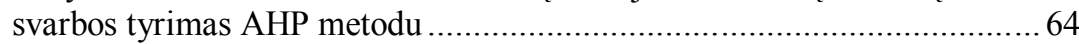

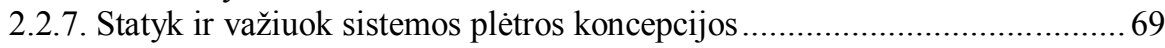

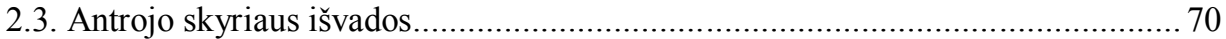

\section{MIESTO AUTOMOBILIŲ STOVĖJIMO VIETŲ EFEKTYVUMO}

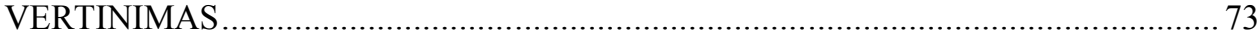

3.1. Sprendimo prièmimo duomenys automobilių stovejjimo vietų gyvenamuosiuose rajonuose daugiatiksliam vertinimui........................................................ 73

3.2. Daugiatikslis vertinimas COPRAS, SAW, TOPSIS ir rezultatų apibendrinimas

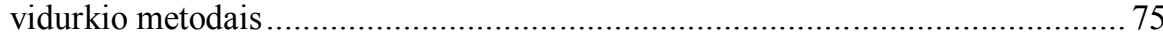

3.3. Sprendimo priėmimo duomenys, automobilių stovèjimo vietų prekybos centruose, daugiatiksliam vertinimui .................................................. 80

3.3.1. Daugiatikslis vertinimas, SAW, TOPSIS ir PROMETHEE metodais........ 82

3.3.2. Prekybos centrų automobilių stovėjimo aikštelių plètros pasiūlymai urbanizuotose (daugiabučių namų) teritorijose ................................... 87

3.4. Statyk ir važiuok automobilių stovèjimo aikštelių vietos parinkimo atranka ....... 92

3.4.1. Statyk ir važiuok sistemos daugiatikslis vertinimas, COPRAS, SAW ir

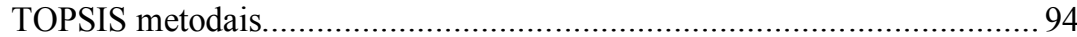

3.4.2. Statyk ir važiuok automobilių stovėjimo aikštelių GIS planavimo bazė ..... 96

3.4.3. Statyk ir važiuok automobilių stovejjimo aikštelių sisteminė atranka ......... 97

3.4.4. Statyk ir važiuok automobilių stovejjimo aikštelių koncepciniai

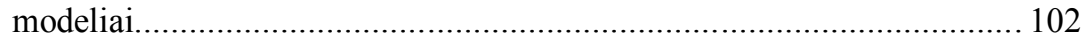

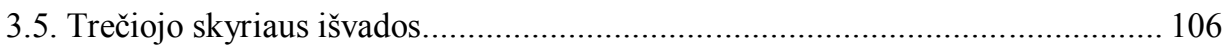

BENDROSIOS IŠVADOS ...................................................................... 109 


\section{AUTORIAUS MOKSLINIŲ PUBLIKACIJŲ DISERTACIJOS TEMA}

SĄRAŠAS

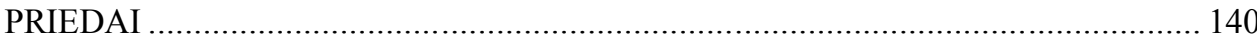

A priedas. Sprendimo prièmimo duomenys, automobilių stovėjimo vietų prekybos centruose, daugiatiksliam vertinimui

B priedas. Bendraautorių sutikimai teikti publikacijoje skelbtą medžiagą mokslo daktaro disertacijoje 145

$\mathrm{C}$ priedas. Autoriaus mokslinių publikacijų disertacijos tema kopijos 156 



\section{Contents}

INTRODUCTION

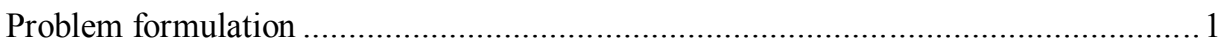

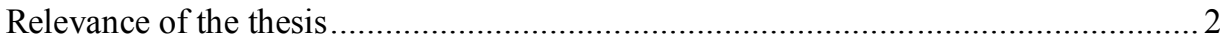

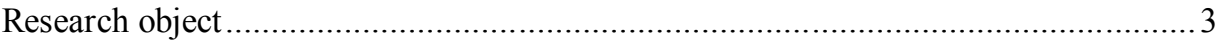

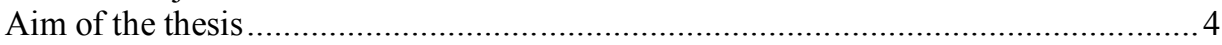

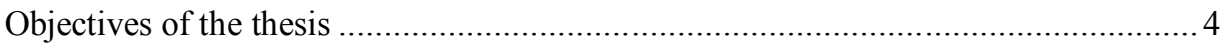

Research methodology ………....................................................................... 4

Scientific novelty of the thesis......................................................................... 4

Practical value of research findings ...................................................................... 5

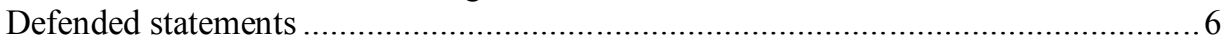

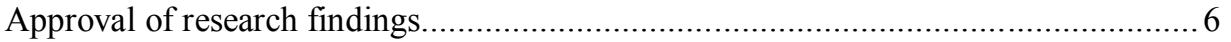

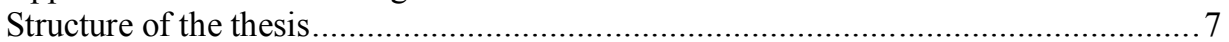

1. THE ANALYSIS OF THE SCIENTIFIC WORKS DEDICATED TO THE PROBLEMS OF CAR PARKING SPACES IN CITIES ……................................. 9

1.1. The origin and the causes of the problem of car parking .................................... 9

1.2. Optimal allocation of parking lots in the city center......................................... 12

1.2.1. The demand and the possibilities for parking spaces in central city areas: old town and city center......................................................... 13

1.2.2. Parking spaces in central city areas ........................................................ 19

1.2.3. Parking spaces in downtown city areas ..................................................... 25

1.3. Other uses of vehicles and the methods for reducing the amount of

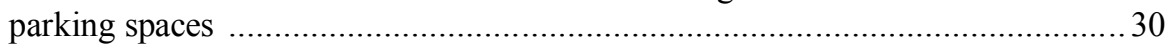


1.4. Innovative and technologically modern parking buildings ..................................32

1.5. The evolution of automobilization in Lithuanian cities .......................................34

1.6. The review of the normative documents which regulate car parking .................. 36

1.7. Conclusions of Chapter One and formulation of thesis objectives ....................... 40

\section{THE THEORETICAL INVESTIGATION AND ANALYSIS OF THE}

SPACES FOR CAR PARKING 43

2.1. The plan and the methodology of the investigation of car parking spaces............ 43

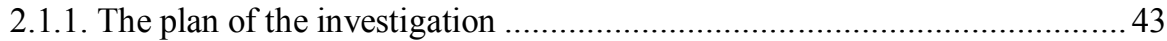

2.1.2. The methods determining the quantity of parked cars............................... 45

2.2. The following stages and the results of the investigation of car parking ...............47

2.2.1. The results of car parking investigation in residential areas ....................... 48

2.2.2. The significance of the quantitative criteria analysis of parking lots in residential districts by the AHP method .................................................... 49

2.2.3. The results of the investigation of car parking in the parking lots of

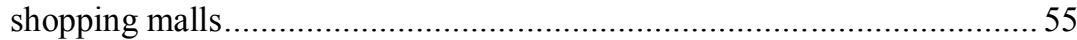

2.2.4. The analysis of the significance of shopping mall parking lot parameters by the AHP method ................................................................5

2.2.5. The principles of the park and ride parking lot development strategy in Vilnius.

2.2.6. The analysis of the significance of the car parking lot indicators of

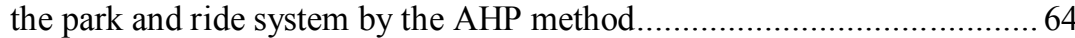

2.2.7. The developmental concepts of the park and ride system.............................. 69

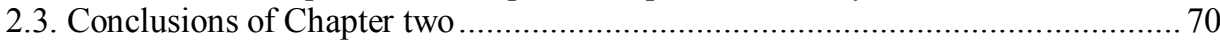

3. THE ASSESSMENT OF THE EFFECTIVENESS OF THE PARKING LOTS

IN CITY 73

3.1. The data-informed decision making for the multi-criteria assessment of

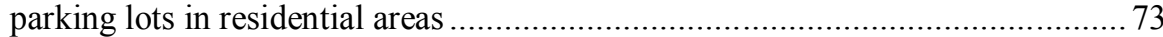

3.2. Multi-criteria assessment and the conclusion of the results by COPRAS,

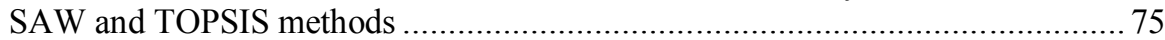

3.3. The data-informed decision making for the multi-criteria assessment of parking lots in shopping malls 80

3.3.1. Multi-criteria assessment by SAW, TOPSIS and PROMETHEE methods

3.3.2. The suggestions for the development of parking lots in shopping malls of urban residential areas 87

3.4. The selection of the places for the park and ride parking lots ............................ 92

3.4.1. The multi-criteria assessment of the park and ride system by COPRAS, SAW and TOPSIS methods 94

3.4.2. The GIS planning database of the park and ride parking lots ...................... 96

3.4.3. The systematical selection of the park and ride parking lots ....................... 97

3.4.4. The conceptual models for the park and ride parking lots ........................ 102

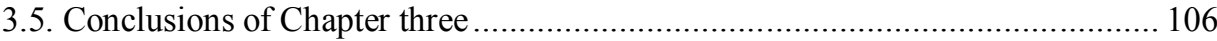


LIST OF SCIENTIFIC PUBLICATIONS BY THE AUTHOR ON THE TOPIC OF THE THESIS

ANNEXES

Annex A. The data-informed decision making for the multi-criteria assesment of parking lots in residential areas

Annex B. Agreements of co-authors to provide published materials in the thesis

Annex C. Author's scientific publications on the topic of the thesis 156 



\section{Ivadas}

\section{Problemos formulavimas}

Viena aktualiausių problemų, su kuria susiduria Lietuvos didžiųjų miestų gyventojai, yra automobilių stovèjimo vietų trūkumas miesto teritorijose: senamiestyje, miesto centre, daugiabučių namų kiemuose, prie gydymo ịstaigų ir prie kitų svarbių traukos objektų. Automobilių stovèjimo vietų trūkumą Lietuvos miestuose lèmé susisiekimo sistemos neprognozuojamos raidos procesai, kurie pradèjo vykti maždaug prieš du dešimtmečius - atgavus nepriklausomybę iš vakarų Europos valstybių buvo masiškai įvežami seni panaudoti lengvieji automobiliai, sparčiai didejantis automobilizacijos lygis, auganti šalies ekonomika ir didejantis visuomenès gyvenimo lygis sutrikdè susisiekimo sistemos infrastruktūros vystymąsi. Šio scenarijaus pasekmè - miesto gyventojų priklausomybė nuo lengvojo automobilio.

Lietuvos didmiesčių gyvenamuosiuose rajonuose susiformavo dviejų tipų automobilių stovejjimo vietų problemos. Pirma problema - sovietmečiu statytuose daugiabučių namų gyvenamuosiuose rajonuose. Antra - naujuose daugiabučiu namų gyvenamuosiuose rajonuose. Sovietmečiu įrengtos automobilių stovẻjimo vietos prie daugiabučių namų šiuo metu neatitinka galiojančių minimalių normatyvinių reikalavimų, vietų trūkumo problemas gyventojai išsprendžia automobilị laikydami gatvėse, ant pėsčiujų ir dviračių 
takų, želdinių teritorijose, vaikų žaidimų aikštelèse ir kitose bendro naudojimo teritorijose. Naujų daugiabučių namų automobilių stovèjimo vietos projektuojamos pagal galiojančius minimalius normatyvinius reikalavimus. Tačiau didejantis gyventojų mobilumas, darbo kelionių atstumas ir kelionès trukmè verčia šeimoje turèti daugiau nei vieną lengvaji automobilị ir numatytų automobilių stovejimo vietų nepakanka norint pastatyti visus automobilius.

Siekiant sumažinti automobilio panaudojimą mieste, būtina vystyti konkurencingą viešaji transportą ir gerinti keleivių pervežimo proceso kokybę. Tam, kad viešasis transportas mieste sėkmingai konkuruotų su automobiliu, būtina skatinti kombinuotojo transporto kelionių sistemas: statyk ir važiuok (angl. „Park and ride“), Palik dviratị ir važiuok viešuoju transportu (angl. „Bike and ride"), Sustok ir išleisk/paimk, ir važiuok (angl. „Kiss and ride“) ir kitas.

Turimais duomenimis, statyk ir važiuok sistemos naudojimo apimtys pasaulyje didèja. Remiantis užsienio šalių patirtimi, sẻkminga statyk ir važiuok sistemos veikla priklauso nuo daugybès veiksnių: nuo miesto fizinès struktūros, žemès ịsisavinimo galimybès, miesto viešojo transporto skatinimo ir valdymo politikos ir kita. Tačiau pagrindinis infrastruktūros objektas, nuo kurio priklauso visa statyk ir važiuok sistemos veikla - automobilių stovèjimo aikštelè. Lietuvoje automobilių stovèjimo aikštelių, kurios būtų oficialiai kombinuojamos su tradicinio miesto viešojo transporto sistema, nèra. Todèl galime daryti išvadą, kad miestuose ši sistema deramai netyrinèta ir šių aikšteliu ịrengimui nèra parengtos metodikos. Tam, kad statyk ir važiuok sistema Lietuvos didmiesčiuose sékmingai konkuruotų su kitomis miesto viešojo transporto sistemomis, būtina ịvertinti automobilių stovèjimo vietų plètrą mieste.

\section{Darbo aktualumas}

Augantis automobilizacijos lygis tiesiogiai susijęs su automobilių stovèjimo vietų poreikiu mieste, kuris turi įtakos miestų plètrai ir blogina žmonių gyvenimo kokybę (Hongbing ir Zhaokang 2011). Dèl istoriškai susiklosčiusio ịvairios paskirties pastatų išsidèstymo, automobilių stovèjimo vietų poreikis miestuose yra skirtingas. Todèl planuojant automobilių stovejjimo aikštelę svarbiausias kriterijus yra vienos stovejimo vietos funkcionavimo pobūdis, o ne aikštelès plotas (Burinskienè et al. 2011).

Mokslininkų nustatyta, kad didmiesčiuose automobiliui stovèti mieste reikia 5-6 vietų (namai-darbas-prekybos centras-namai), tai yra kiekvienam lengvajam automobiliui reikia išskirti mažiausiai apie $100 \mathrm{~m}^{2}$ teritorijos. Urbanistai teigia, kad milijoniniuose didmiesčiuose susisiekimo sistemos reikmèms tenka apie 40 \% (kai kur daugiau nei $60 \%$, pavyzdžiui, Los Andželas, JAV) bendro miesto 
ploto, kituose didmiesčiuose 20-25\%, o mažesniuose miestuose apie $10 \%$ (Juškevičius et al. 2013).

Lietuvoje ir pasaulyje automobilių stovejjimo vietų reguliavimo procesą lemia politiniai sprendimai, todèl jam reguliuoti, ypač miesto centruose, reikalingi teisiniai, organizaciniai ir finansiniai mechanizmai (Juškevičius et al. 2006). Tačiau šiandien Lietuvos miestai, kaip ir dauguma kitų šalių miestų, automobilių stovèjimo vietų reguliavimo procesą normuoja tradicinio sąrašo forma (liet. STR, rus. СНиП, vok. DIN, šveic. SN, est. RTL ir kt.). Automobiliu stovėjimo vietų normatyvų skaičiavimo principai yra pasenę, netenkina esamų poreikių, todèl juos būtina keisti (Willson 2013).

Rengiamo darbo aktualumą galima patvirtinti ir Europos Komisijos dokumentais, kuriuose nurodoma kuo greičiau spręsti automobilizacijos lygio, grūsčių ir oro taršos klausimus Europos miestuose.

Europos Komisijos dokumentuose - 2009 m. vasario mèn. Žaliosios knygos veiksmų plane (EC 2007) ir $2011 \mathrm{~m}$. Baltojoje knygoje (EC 2011) nurodyta Europos miestuose diegti kombintuotų kelionių skatinimo sistemų koncepcijas, kuriu pagrindu bus pasiektas bendros Europos transporto erdvès kūrimo planuose numatytas siekis: iki $2030 \mathrm{~m}$. Europos Sajungos šalyse dvigubai sumažinti ịprastiniu kuru varomų automobilių naudojimą miestuose, o iki 2050 m. pasiekti, kad miestuose jų nebeliktų. Taip pat, Lietuvos didmiesčiams (Vilnius, Kaunas, Klaipèda, Šiauliai ir Panevėžys) numatyta Europos Sajungos parama 2014-2020 m. laikotarpiui statyk ir važiuok sistemos automobilių stovèjimo aikštelių plètrai. Ši parama skirta pagal miestų plètros antraji prioritetą „Darnios miestų transporto sistemos kūrimas ir judumo gerinimas“, pagal 2.1 uždavinị „Didinti viešojo transporto konkurencingumą" ir 2.1.2 priemonę „Viešojo ir privataus transporto sąveikos sistemų nutolusiose nuo miestų centrų ir miesto prieigos kūrimas (statyk ir važiuok automobilių stovejjimo aikštelių plètra)“".

\section{Tyrimo objektas}

Darbo tyrimo objektas - asmeninių kelionių automobilių stovejjimo vietų didmiestyje pasiskirstymo sistema.

\section{Darbo tikslas}

Darbo tikslas - pasiūlyti automobilių stovėjimo vietu mieste plètros vertinimo modelị ir pateikti originalius automobilių stovèjimo aikštelių plètros koncepcinius sprendinius. 


\section{Darbo uždaviniai}

1. Atlikti mokslinès literatūros, susijusios su automobilių stovèjimo vietų trūkumu, analizę.

2. Atlikti automobilių stovejjimo vietų Vilniaus miesto daugiabučių namų ir prekybos centrų automobilių stovejimo aikštelèse tyrimus.

3. Nustatyti daugiabučių namų gyventojų poreikị naudotis prekybos centrų automobilių stovejjimo aikštelèmis ne apsipirkimo tikslais.

4. Sukurti prekybos centrų automobilių stovejjimo aikštelių vertinimo sistemą, kuri iš dalies išspręstų automobilių stovèjimo vietų trūkumą daugiabučių namų aikštelèse.

5. Pasiūlyti statyk ir važiuok sistemos automobilių stovèjimo aikštelių mieste sisteminès atrankos strategiją ir pateikti reikalavimus susisiekimo sistemos infrastruktūrai planuoti.

\section{Tyrimų metodika}

Darbe panaudoti šie tyrimo metodai: mokslinès teorinès analizès, ekspertinis, daugiatikslis ir natūrinių tyrimų.

Naudojant mokslinès teorinès analizès metodą atlikta šiuolaikinès mokslinès literatūros, Europos Komisijos leidinių ir kitų teisinių šaltinių apžvalga.

Naudojant natūrinių tyrimų metodą nustatytas daugiabučių namų teritorijose ir prekybos centrų automobilių stovejjimo aikštelèse stovinčių automobilių skaičius, nustatytos lengvujų automobilių laikymo sąlygos, lengvujjų automobilių stovejjimo aikštelių užpildymo koeficientai, automobilių stovejjimo vietu poreikis ir taip toliau.

Naudojant ekspertinius metodus nustatyti automobilių stovèjimo vietų kriterijai ir suskaičiuoti jų svoriai. Vèliau darbe taikomi ịvairūs daugiatiksliai metodai: TOPSIS, SAW, COPRAS, PROMETHEE, kurių pagrindu įvertinta automobiliu stovejjimo vietų ir aikšteliu prioritetinè eilè. Nustatyta nuo kokių kriterijų priklauso prekybos centrų automobilių stovèjimo aikštelių užpildymo koeficientai, pasiūlyta statyk ir važiuok sistemos automobilių stovejjimo aikštelių mieste sisteminès atrankos strategija.

\section{Darbo mokslinis naujumas}

Rengiant disertaciją buvo gauti šie statybos inžinerijos mokslui nauji rezultatai: 
1. Sukurta prekybos centrų automobilių stovèjimo aikštelių plètros kriterijų sistema, kurią galima naudoti miesto kompleksinio planavimo etape.

2. Taikant analitinị hierarchijos proceso (AHP) metodą gauti kriterijų svorių skaitiniai įverčiai, kurie leido sudaryti statyk ir važiuok sistemos automobilių stovejjimo aikštelių prioritetinę eilę ir pagal ją pasiūlyti inovatyvią automobilių stovèjimo aikštelių sistemą Vilniaus mieste.

3. Sudaryti trys originalūs statyk ir važiuok sistemos automobilių stovejimo aikštelių koncepciniai modeliai, kurie pritaikyti realiai didmiesčio erdvei.

\section{Darbo rezultatų praktinè reikšmè}

Disertacijoje nustatyta prekybos centrų automobilių stovèjimo aikštelių kriterijų sistema, kuri gali būti praktiškai taikoma kompleksinio planavimo etape. Tai yra priemoné, leidžianti teritoriju planavimo specialistams matematiškai apskaičiuoti automobilių stovejjimo vietų skaičių gyvenamuosiuose rajonuose, ivertinant prekybos centrų automobilių stovèjimo aikštelių plètros variantus. Sukurta kriterijų sistema tinkama Lietuvos didmiesčiams ir kitiems panašaus dydžio užsienio šalių miestams.

Atsižvelgiant ị Europos Sajungos 2014-2020 m. laikotarpio paramą, pagal kurią Lietuvos penkiems miestams numatytas finansavimas statyk ir važiuok sistemos automobilių stovejjimo aikštelių plètrai, pasiūlytas metodas leidžiantis nustatyti racionaliausias statyk ir važiuok sistemos automobilių stovejjimo aikštelių dislokacijos vietas. Papildomai detalizuoti trys statyk ir važiuok sistemos automobilių stovejjimo aikštelių koncepciniai modeliai ir jie pritaikyti bei vizualizuoti realioje miesto erdvejje.

\section{Ginamieji teiginiai}

1. Urbanizuotose daugiabučių namų gyvenamujų rajonų teritorijose irengtas prekybos centrų automobilių stovèjimo aikšteles galima efektyviau išnaudoti automobiliams statyti.

2. Urbanizuojamose teritorijose, kompleksiškai planuojant daugiabučių namų gyvenamuosius kvartalus ir prekybos centrų automobilių stovèjimo aikšteles, tam tikrą dali daugiabučių namų gyventojų 
automobilių stovèti galima nukreipti ì prekybos centro automobilių stovejjimo aikšteles.

3. Kuriamos ir plètojamos statyk ir važiuok sistemos didmiestyje kriterijų svarbą ir itaką jos veiksmingumui planuojamaisiais eksperimentais tyrimais nustatyti dažniausiai neịmanoma, todèl šiam tikslui geriausiai tinka taikyti daugiatikslius sprendimų prièmimo metodus.

\section{Darbo rezultatụ aprobavimas}

Disertacijos tema yra publikuoti penki moksliniai straipsniai: du - mokslo žurnaluose, itrauktuose $i$ Thomson Reuters Web of Knowledge (ISI Web of Science) sąrašą (Pirmas mokslinis straipsnis paskelbtas užsienio žurnale, neturinčiame citavimo rodiklio (Maliene et al. 2011), antrasis - turinčiame citavimo rodikli (Palevičius et al. 2013). Vienas - kitų tarptautinių duomenų bazių leidinyje (Palevičius and Lazauskaitè 2014); vienas - konferencijos ISI Proceedings medžiagoje (Zagorskas and Palevičius 2011); vienas recenzuojamoje tarptautinių konferecijų medžiagoje (Burinskienè et al. 2014).

Rengiant disertaciją atliktų tyrimų rezultatai buvo paskelbti penkiose mokslinèse konferencijose Lietuvoje ir užsienyje:

- 14-ojoje Lietuvos jaunujų mokslininkų konferencijoje „Civiliné inžinerija ir geodezija " $2011 \mathrm{~m}$. Vilniuje;

- 8-ojoje tarptautinèje konferencijoje „Environmental engineering“ 2011 m. Vilniuje (Zagorskas and Palevičius 2011);

- Tarptautineje VISBY projekto konferencijoje „Capacity building in sustainable urban planning and development in Lithuania, Russia, Sweden and Ukraine" 2013 m. Nidoje;

- Tarptautineje konferencijoje „III Postgraduate workshop of the ESPON/ENECON procect" $2014 \mathrm{~m}$. Olburgo mieste, Danijoje (Galland 2014);

- 9-ojoje tarptautinejje konferencijoje „Environmental engineering“ 2014 m. Vilniuje (Burinskiene et al. 2014). 


\section{Disertacijos struktūra}

Disertaciją sudaro ịvadas, 3 skyriai, bendrosios išvados, literatūros sąrašas, publikacijų sąrašas.

Darbo apimtis yra 140 puslapių, darbe - 36 lentelès ir 31 paveikslas. Rašant disertaciją vadovautasi 135 mokslinès literatūros ir kitais šaltiniais. 



\section{1}

\section{Mokslo darbų, skirtų automobilių stovèjimo vietų miestuose problemoms tirti, analizè}

Skyriuje pateikiama automobilių stovejjimo vietų (toliau - ASV) problemos kilme ir jos atsiradimo priežastys. Apžvelgiama pasaulio miestuose ASV išsidèstymo sistema. Atlikta, Europos Sajungos (toliau - ES) ir kitų pasaulio šalių norminių dokumentų, reglamentuojančių lengvujų automobilių (toliau LA) stovèjimą skirtingose miesto teritorijose, analizè.

Skyriaus tematika paskelbti du autoriaus straipsniai (Zagorskas and Palevičius 2011; Palevičius and Lazauskaitė 2014).

\subsection{Automobilių stovėjimo problemos kilmè ir jos atsiradimo priežastys}

ASV problemos reikšmė pirmą kartą nustatyta 1928 m. Čikagoje (JAV). Tada pirmą kartą pasaulio istorijoje pradèta taikyti draudimas transporto priemonèms (toliau - TP) stovèti centrinëje miesto dalyje (Burinskiené et al. 2011). Teigiama, kad tai automobilių statymo (toliau - AS) politikos pradžia, kuria 
buvo siekiama sumažinti pasiūlos ir paklausos disproporcijas. AS siauraja prasme suprantamas kaip elementarūs veiksmai siekiant pastatyti ir laikyti TP specialiai jai skirtoje ar laisvai pasirinktoje vietoje. Plačiaja prasme AS suprantamas kaip vienas iš miesto sistemos ir jos struktūros planavimo bei funkcionavimo procesų. Šis procesas šiuolaikiniame mieste neišvengiamas, tačiau vertinamas kaip esminių problemų šaltinis, nes apie 90 \% laiko LA stovi (Juškevičius et al. 2013).

XX a. pradžioje LA protegavimo politika lèmė ekonomikos augimą ir su ja susijusius inovatyvius urbanistinius sprendimus. Pirmosios daugiaaukštès automobilių stovejjimo aikštelès (toliau - ASA) buvo pastatytos $1905 \mathrm{~m}$. Paryžiuje (Prancūzija), 1907 m. Čikagoje (JAV), 1908 m. Niujorke (JAV), 1920 m. Sinsinatyje (JAV) ir kt. (McDonald 2012). Kartu su didejjančia automobilizacija proporcingai buvo plètojama susisiekimo sistemos ( toliau SS) infrastruktūra (gatvių tinklas, pessčiujuc takai, tiltai, estakados ir pan.), inžinerinė infrastruktūra (elektros tiekimo sistema, ịvairi eismo ir reguliavimo ịranga, informacinè sistema ir kita), taršos slopinimo įranga (pylimai, specialios želdinių juostos, medžio ir garsą slopinančios užtvaros ir kita.).

Atrodè, kad LA protegavimo politika miestams duos apčiuopiamos ilgalaikès ekonominès ir socialinès naudos. Išaugo gyventojų susisiekimo galimybès, padidejo gyvenamosios erdvès gyvybingumas. Auganti automobilizacija paskatino sukurti papildomų darbo vietų, nes atsirado poreikis statyti naujus SS, inžinerinès ir kitus infrastruktūros objektus.

Augantis automobilizacijos lygis parode, kad LA protegavimo politika grịsta kiekybiniu miesto vystymu. Pasiekus 100 aut./1000 gyv. atsirado pirmosios AS problemos. Pirmiausia ASV trūkumas pasireiškẻ centrinèse miestų dalyse. Vèliau ASV trūkumas atsirado prie geležinkelių ir autobusų stočių, prie oro uostų, prie gydymo ịstaigų, prie gamybos įmonių, daugiabučių namų gyvenamuosiuose rajonuose ir prie kitų traukos objektų.

Pirmieji Europoje ASA talpos tyrimus skirtingose miesto teritorijose XX a. 7-ojo dešimtmečio pirmojoje pusèje pradèjo tyrinèti Jungtinès Karalystès transporto specialistai. Vadovaujami Buchanano, valdžios nurodymu jis sprendè transporto ribojimo klausimus miestuose. Tyrimų duomenys pristatyti istorinejje Buchanano mokslinejje ataskaitoje (1963), kurioje buvo nurodyta būtinybė riboti automobilizacijos lygio augimą miestuose. Pastaraji dešimtmeti publikacijų ir mokslinių darbų šia tema ypač pagausëjo. Tikètina, kad Europoje LA stovejjimo vietų tyrinejjamo populiarumui ženklią ịtaką padaré 7-ajame dešimtmetyje publikuota Buchanano mokslo ataskaita. Palaipsniui transporto eismo tyrimus ir grūstis, LA stovejjimo vietų tyrimus pradejjo vykdyti ir rezultatus publikuoti platesnis mokslininku ratas: Foster (1963), Smeed (1966, 1968), Godfrey (1970). Vèliau LA stovèjimo tyrimus ir planavimo procesus Austrijos miestuose eilę metų vykdė Pech, Warmth, Jens, Zeininger (2009). Lenkijos didmiesčių AS 
problemas nagrinèja Pęski ir Czechowski (2001), Szarata, (2007), Czerwinski (2013) ir kiti mokslininkai.

Burinskienè (2011) teigia, kad ASV paieška tapo kasdienine problema mieste, neradę laisvos stovejjimo vietos, vairuotojai ieško kitos, kurie papildomai apkrauna gatvių tinklą ir ASA, sudarydami neigiamą poveiki aplinkai. Lim (2010) rašo, kad didžiausias taršos šaltinis mieste, kuris kelia didžiausią grèsmę žmonių sveikatai, yra LA. Psiloglou su bendraautoriais (Psiloglou et al. 2013), teigia, kad LA sudaro antropogeninius (kietosios dalelès, sieros ir ozono dioksidas, anglies monoksidas ir kita) ir yra natūralius taršos šaltinius mieste. Europos aplinkos agentūros (European Environment Agency - EEA) 2013 m. ataskaitoje teigiama, jog transporto sukeltas oro užterštumas Europos miestuose sudaro $70 \%$ viso oro užterštumo.

Miestų planavimo požiūriu pagrindinès problemos kyla dèl nepakankamo susisiekimo infrastruktūros išvystymo ir besiplečiančių miestų (Lazda and Smirnovs 2014). Nuo automobilizacijos lygio atsiliekantis susisiekimo infrastruktūros vystymas didina eismo grūstis, ilgina LA kelionès laiką, teršia gyvanamają aplinką (Podvezko and Sivilevicius 2013). Mokslų daktaro Grigonio disertacijoje (2005) teigiama, kad mažejjantis užstatymo tankis mieste lemia didesni privačių LA poreikị. Didesnis privačių LA skaičius sukelia gyvenamuosiuose rajonuose viešujų erdvių perpildymo LA problemą. Taip pat neįskaitinių ịvykių tikimybè mieste auga, kai didejja LA skaičius. Remiantis atliktais darbais ir statistiniais duomenimis, nustatyta, kad svarbiausią reikšmę eismo saugumui turi žmogiškasis veiksnys, tai yra visuma asmens fiziniu ir psichologinių savybių, lemiančių sèkmingą vairuotojo darbą ir daugiausia eismo ịvykių įvyksta dèl eismo dalyvio kaltès. Taip pat nustatyta, kad apie $65 \%$ eismo ivvykiu kaltininku yra LA vairuotojai (Lipnickas and Nagurnas 2012). Zaranka teigia (2012), kad eismo îvykiai daugeliu atvejų gali būti prognozuojami ir neutralizuojami, tačiau yra problema, susijusi su žmogiškuoju veiksniu. Siekiant sumažinti eismo ịvykių skaičių ir jų pasekmes, turi būti sutelktas dèmesys ị sistemini metodą, apimantị visapusiškų priemonių plètojimą. Taigi augantis automobilizacijos lygis mažina TP vidutini greitị mieste, tuo užtikrinant mažesnę ịskaitinių ịvykių tikimybę, bet didina bendrą neįskaitinių ịvykių statistiką.

Kaip rodo užsienio miestų su aukštu automobilizacijos lygiu patirtis, esant tradiciniam miesto išplanavimui ir netaikant jokių LA apribojimų, irengti reikiamą ASV kiekị neįmanoma. 


\subsection{Automobilių stovèjimo vietų išsidẻstymo sistema mieste}

Šiuolaikiniuose miestuose galima išskirti tris zonas, kurios sudaro miesto ASV sistemą (1.1 pav.). Pirmoji - centriné zona, ị kurią ịeina senamiestis ir miesto centras. Antroji - vidurinè zona (gyvenamieji rajonai, prekybos centrai (toliau PC), komercinès įmonès, gydymo ịstaigos, mokslo įstaigos ir kita), trečioji priemiestiné zona (oro uostas, gamybos ir pramonès įmonés, įvairūs verslo centrai ir kita).

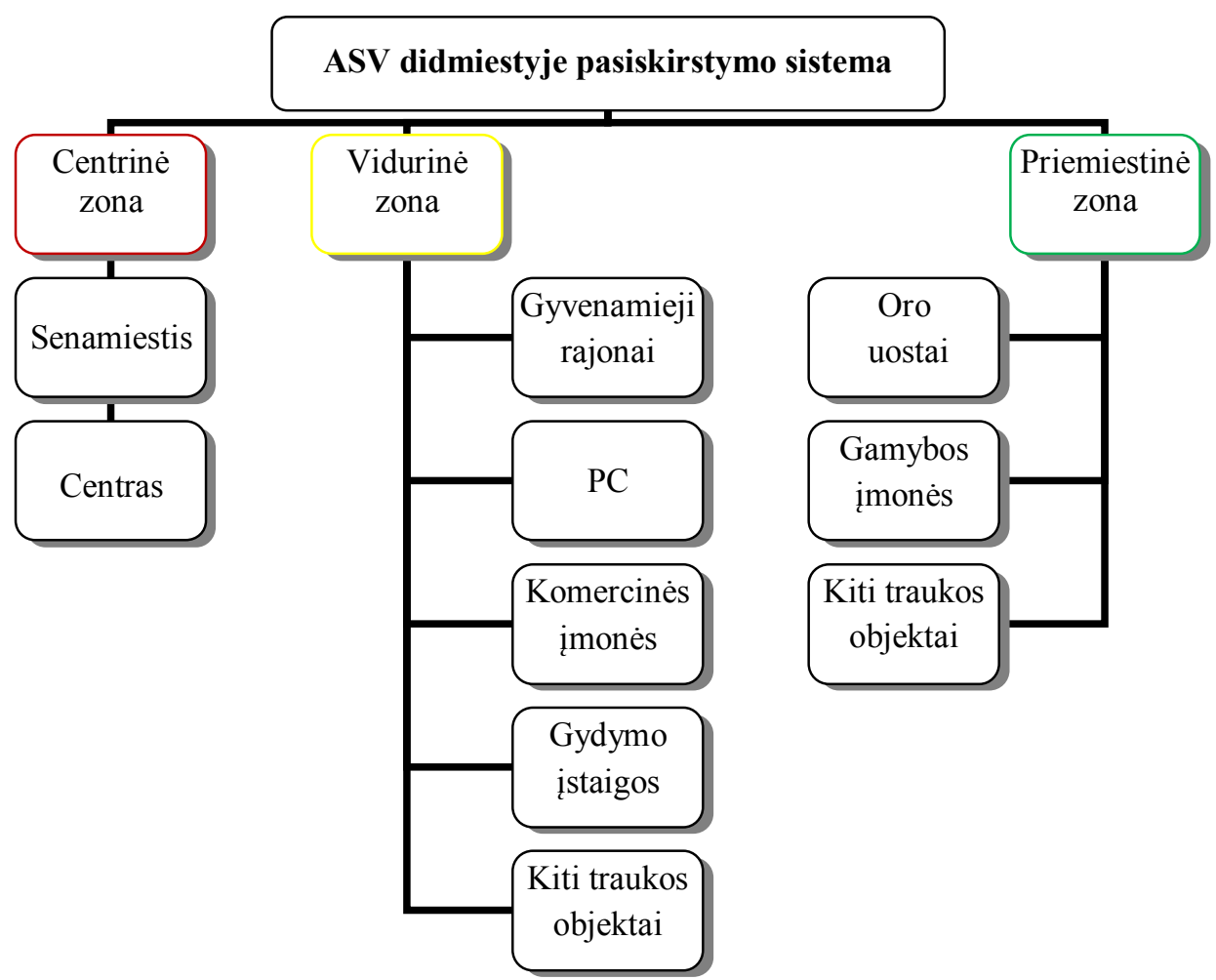

1.1 pav. Automobilių stovejjimo vietų didmiestyje pasiskirstymo sistema (sudaryta autoriaus)

Fig. 1.1. Car parking lots distribution system in a big city (author's)

Šios trys miesto zonos skiriasi viena nuo kitos, nes kiekviena zona išskirtinè savo fizionominiais bruožais ir infrastruktūra. Skirtingas užstatymo tipas, užstatymo tankis, pastatų aukštis, gatvių tinklas, VT išvystymo lygis, darbo vietų 
sklaida. Kiekvienoje zonoje dėl žemès kainos ar jos stygiaus ASA statybos mastas yra skirtingas.

\subsubsection{Automobilių stovèjimo vietų poreikis ir galimybės centrinèse miestų zonose: senamiestyje ir miesto centre}

Senamiestyje dẻl istoriškai susiklosčiusio ịvairios paskirties pastatų išdèstymo ASV ịrengimo galimybès yra ribotos. Užsienio praktikoje dažniausiai ASV irengiamos gatvėse, esant galimybei statomi antžeminiai ir požeminiai daugiaaukščiai garažai (Arnott and Inci 2010). Lietuvoje pagal statybos techninị reglamentą (toliau - STR) 2.06.01:1999 „Miestų, miestelių ir kaimų susisiekimo sistemos“ vienai ASV ịrengti reikalingas $20 \mathrm{~m}^{2}$ žemès plotas. Senamiestyje įrengiant ASA ir ASV svarbiausi kriterijai yra aikštelès dydis, ASV skaičius ir vienos LA stovejjimo vietos funkcionavimo pobūdis. Todèl ASV reguliavimas senamiesčiuose yra sudètingas procesas ir ASV paklausa viršijanti pasiūlą. $\mathrm{XX}$ a. viduryje daugelyje Europos miestų AS politika dažniausiai buvo paremta ASA ịrengimu senamiesčio gatvėse, antžeminių ir požeminių garažų statyba (Arnott 2006). Taip buvo tikimasi išspręsti ASV trūkumo problemas.

Per pastaruosius kelis dešimtmečius didieji Europos miestai senamiesčiuose rado efektyvius AS problemų sprendimo būdus. Pavyzdžiui, Londonas (Anglija) vienas pirmujų miestų, kuris $1972 \mathrm{~m}$. ịvedè maksimalią ASV skaičiaus normą. $2003 \mathrm{~m}$. vasario $17 \mathrm{~d}$. Londone pradejo veikti nauja gatvių kainodaros sistema. Pagrindinis projekto tikslas - skatinti keliones VT, dviračiais, motociklais ir pésčiomis. Šis mokestis yra pavadintas „grūsčiu mokesčiu“ ir didžioji dalis surinktų pinigu yra skiriam VT išlaikyti bei plètoti. Šiuo metu 10 svarų sterlingų paros mokesti turi mokèti registruoto LA savininkas, jei LA kerta ženklais pažymètą zoną tarp 7.00 val. ryto ir 18.00 val. vakaro. Zonos prieigose yra irengtos kameros, kurios nuskaito ir atpažissta ịvažiuojančių LA numerius ir sutikrina juos su LA registru. Vidinejje apmokestinamose teritorijos zonoje irengtos kameros, kurios kontroliuoja ar nèra tvarkos pažeidejų. Mokestis turi būti sumokètas iki 22 val. vakaro, kitaip jis išauga ir galų gale tampa didele bauda (Thompson and Berman 2012). Itvedus ši mokestị, įvažiuojančių TP skaičius sumažèjo apie $30 \%$. Apie 50-60\% šių TP vairuotojų ir keleivių persèdo ị VT, 20-30\% iš viso atsisakè kelionių, o likę atidèjo keliones, važiavo dviračiu ar motociklu. Kelionès trukmè sumažèjo vidutiniškai apie $15 \%$, o greitis padidejo 17 \% (Prud'homme and Bocarejo 2005).

Griežta ir labai įdomi ASV politika taikoma Olandijos miestuose, kuriuose ivvesta maksimalių ir minimalių normų sistema. Prie darboviečių naudojami trys rodikliai: 10, 20 ir 40 stovejjimo vietų 100 darbuotojų. Žemiausias iš šių rodiklių (10 stovejjimo vietų/100 darbuotojų) yra naudojamas tankiai užstatytose 
teritorijose, o rodiklis 40 stovejjimo vietų/100 darbuotojų yra skirtas ekstensyviai užstatytose teritorijose (Kodransky and Hermann 2011).

Viena pelningiausių už LA stovèjimą mokesčiu rinkliavos sistema ịdiegta Norvegijos miestuose (1.2 pav.). 1986 m. sausị Bergene, 1990 m. vasarị Osle ir $1990 \mathrm{~m}$. spali Trondheime senamiesčio gatvèse buvo įdiegta nauja rinkliavų žiedo kainodara. Jị sudaro nuo 7 iki 24 rinkliavų punktų, kurie išdèstyti $3-8 \mathrm{~km}$ atstumu nuo miesto centro. Važiuojanti TP yra apmokestinama kiekvieną dieną. Rinkliavos nèra diferencijuojamos pagal paros laiką ir todèl yra labai paplitę nuolatiniai leidimai: dienai, mėnesiui, metams (Ieromonachou et al. 2006).

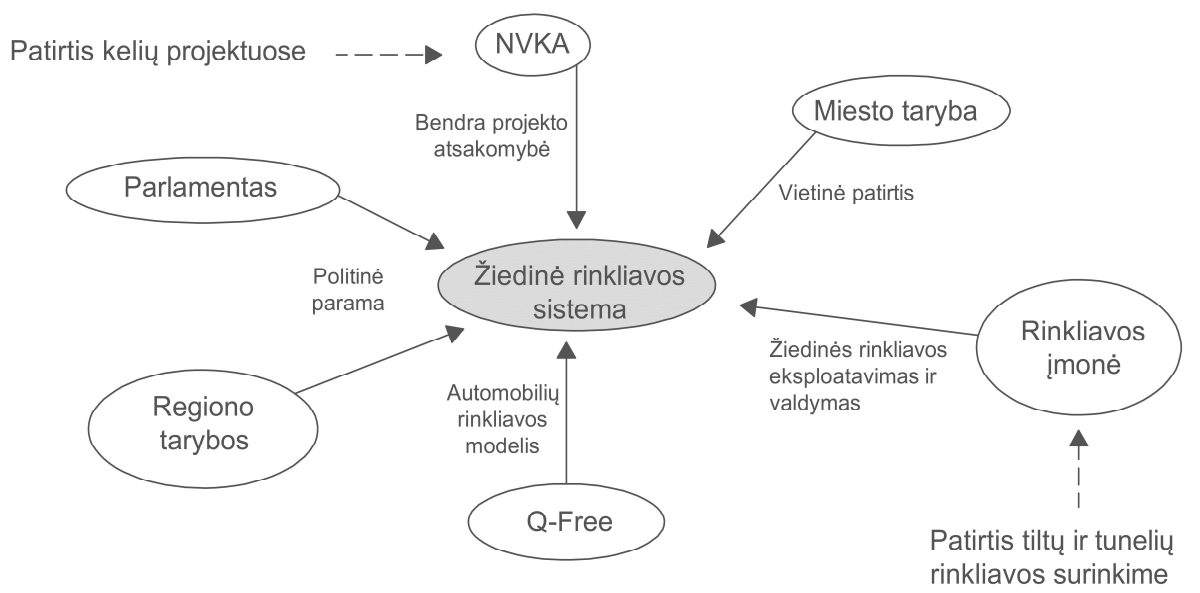

NVKA - Norvegijos viešujų kelių administracija

Q-Free - elektronikos ịmonè, atsakinga už automobilių mokesčių rinkliavos sistemą

1.2 pav. Pagrindiniai partneriai, igyvendinantys rinkliavų surinkimo strategijas Norvegijoje (Ieromonachou et al. 2006)

Fig. 1.2. Main partners in implementing tolling strategies in Norway (Ieromonachou et al. 2006)

Žiedų atsiradimas beveik nesumažino ASV poreikio. Pirmaisiais metais rinkliavų žieduose ASV sumažejjimas siekè tik $5 \%$ (Waerstad 1992), bet surenkamos už AS pajamos $2006 \mathrm{~m}$. sudarè nuo $220 \mathrm{mln}$. iki $1192 \mathrm{mln}$. Norvegijos kronų. Detalesnè informacija pateikta 1.1 lentelèje.

Kitas sprendimo būdas mažinti LA skaičių senamiesčiuose yra ASV progresinių mokesčių rinkliava. Ciurichas (Šveicarija), Antverpenas (Belgija), Viena (Austrija), Madridas (Ispaniją) ir kiti miestai, ribinių kaštų padidèjimą už AS sieja su jo stovèjimo trukme. Pavyzdžiui, Madride LA gatvèje galime laikyti neilgiau kaip dvi valandas, mokestis yra didinamas kas 20 min. (Kodransky and Hermann 2011). 
Belgrade (Serbija) yra ribojamas LA stovejimo trukmè. Senamiestis ir centrinė miesto dalis suskirstyta $\mathfrak{i}$ tris rinkliavų zonas: pirmoje zonoje galima stovèti ilgiausiai 1 val., antrojoje - 2 val. ir trečiojoje - 3 val. (Simićević et al. 2012). Nustačius, kad LA stovi ilgiau negu jam leidžiama, ị vietą iškviečiama speciali TP, kuri nugabena LA ị saugojamą ASA.

1.1 lentelè. Rinkliavos žiedų charakteristika Norvegijoje (Ieromonachou et al. 2006)

Table 1.1. Comparative characteristics of the current Norwegian toll rings (Ieromonachou et al. 2006)

\begin{tabular}{lccc}
\hline Charakteristikos & Bergenas & Oslas & Trondheimas \\
\hline $\begin{array}{l}\text { Gyventojų skaičius, tūkst. } \\
\text { Žiede gyvenančių žmonių procentas, } \\
\%\end{array}$ & 10 & 60 & 150,0 \\
\hline $\begin{array}{l}\text { Rinkliavos žiedo kainodaros pradžia, } \\
\text { metai }\end{array}$ & 1986 & 1990 & 1900 \\
\hline Rinkliavos plotas, km ${ }^{2}$ & 18 & 64 & 50 \\
\hline Rinkliavos punktų skaičius & 7 & 19 & 24 \\
\hline $\begin{array}{l}\text { Lengvujų automobilių mokestis } \\
\text { Norvegijos kronomis (NOK) }\end{array}$ & 15 & 20 & 15 \\
\hline $\begin{array}{l}\text { Rinkliavos trukme } \\
\text { Eksploatacijos išlaidos per dieną, }\end{array}$ & 73,0 & 248,9 & 74,9 \\
\hline $\begin{array}{l}\text { tūkst. (NOK) } \\
\text { Metinés pajamos, mln. (NOK) }\end{array}$ & 220,0 & 1192,0 & 210,0 \\
\hline
\end{tabular}

Europos miestuose, ypač senamiesčiuose, labiausiai paplitusi TP reguliavimo zonų rinkliavos sistema, kuri suskirstyta ì skirtingas mokejjimo zonas. TP rinkliavos zonų skaičius svyruoja nuo 2 iki 4. Šių zonų suskirstymas ir jose kainų diferenciacija leidžia optimizuoti ASV panaudojimą senamiesčio gatvèse (Pierce and Shoup 2013).

$1995 \mathrm{~m}$. Vilniuje ASA apyvartos padidinimui senamiestyje pirmą kartą ịdiegta rinkliavos sistema. Mokamų ASV skaičius kasmet buvo didinamas (1.2 lentelè), tačiau iki šių dienų ASV problema išliko aktuali.

Vilniaus miesto SS strateginè kryptis pagal Vilniaus miesto BP sprendinius - miesto centre prioritetą skirti VT, pėsčiujų ir dviratininkų eismui. Siekiama riboti ASV skaičių ir naujų daugiaaukščiu požeminių LA saugyklų plètrą, ją siejant su LA skaičiaus mažinimu urbanizuotose miesto dalyse. Tam tikslui buvo pastatytos LA saugyklos Gedimino prospekte ir Tilto gatveje, taip pat numatyta 
LA saugyklos statyba Lelevelio gatvèje. Jų tikslas nèra ASV skaičiaus didinimas, o antžeminès erdvès atlaisvinimas nuo stovinčių LA.

1.2 lentelè. Savivaldybės mokamų automobilių stovejimo vietų skaičius $1995-2011 \mathrm{~m}$.

Table 1.2. Paid car parking lots in the municipality in 1995-2011

\begin{tabular}{|c|c|c|c|c|c|c|c|c|c|}
\hline ASV skaičius & 1995 & 1996 & 1997 & 1998 & 1999 & 2000 & 2001 & 2002 & 2011 \\
\hline $\begin{array}{l}\text { Mokamų vietų } \\
\text { sk. }\end{array}$ & 991 & 1332 & 2394 & 2578 & 2578 & 3066 & 3522 & 3420 & 5113 \\
\hline $\begin{array}{l}\text { Rezervuotos } \\
\text { vietos }\end{array}$ & 46 & 84 & 120 & 150 & 150 & 308 & 335 & 315 & 305 \\
\hline Garažų sk. & - & - & - & - & 1 & 1 & 1 & 1 & 3 \\
\hline $\begin{array}{l}\text { Vietos } \\
\text { garažuose }\end{array}$ & - & - & - & - & 248 & 248 & 248 & 368 & 368 \\
\hline
\end{tabular}

Daugelyje pasaulio miestuose veikianti rinkliavų už LA stovèjimą strategija yra orientuota i vieninteli tikslą - surinkti kuo daugiau pinigu i i miesto biudžetą. Apmokestinti LA stovejimą ar apriboti ASV skaičių senamiesčiuose - būtina. Tačiau apmokèjimo sistema turi būti lanksti ir patogi ne tik miesto gyventojui ir svečiui, bet ir apmokestinimo zonose dirbantiesiems žmonėms. Apmokestinus ASV senamiestyje dideliu tarifu, dirbantiems žmonèms turi būti užtikrintas patogus atvykimas iki darbovietės. Kaip pavyzdi galima pateikti $2008 \mathrm{~m}$. gegužès $28 \mathrm{~d}$. Bolonijos senamiestyje (Italija) atidarytą 7 aukštų ir $84 \mathrm{LA}$ talpinanti automatizuota požeminè ASA (1.3 pav.). Ją suprojektavo ir pastatè italų įmone „Trevipark“. Ši ASA yra cilindro formos ir ịkasta į žemę. Cilindro skersmuo - 19,0 metrų, gylis - 23,5 metrai, vienos ASV plotas $-13,5 \mathrm{~m}^{2}$. Ši inovatyvi ASA leidžia sutaupyti $32,5 \%$ žemès ploto nuo kiekvienos ASV, nes jai nereikalingas įvažiavimas. ASA įdiegta moderni automotizuota valdymo sistema, kuri dirba 24 valandas per parą. LA pastatymo procesas prasideda atvažiavus iki LA paèmimo punkto, kur vairuotojui neišlipant iš LA ir naudojant kortelę arba automatinio numerių nuskaitymo sistemą atidaromi pakèlimo vartai ir LA užvažiuoja ant platformos. Išlipdamas iš LA vairuotojas naudodamas elektroninę kortelę uždaro pakèlimo vartus ir LA nugabenamas i jam skirtą ASV. LA susigrąžinimo būdas panašus kaip ir ịvažiavimo. Pasinaudojus elektronine kortele, LA gražinamas savininkui (Geol et al. 2012).

ASV trūkumo problemos kyla miestų centrinèse dalyse. Šioje vietoje koncentruojasi daugybe visuomeninès paskirties pastatų: gamybos ir pramonès imonių, parduotuvių, gydymo ịstaigų ir taip toliau. Šių objektų lankytojams reikia sudaryti sąlygas lengvai ir patogiai rasti laisvą vietą viešoje ASA. ASV trūkumo problemos mastas priklauso ne tik nuo LA skaičiaus, bet ir nuo lankytojų aktyvumo. Mokslų daktarès Ušpalytės-Vitkūnienès disertacijoje rašoma (2006), kad vakarų Europos miestų gyventojai vidutiniškai per dieną LA 
atlieka 4-5 keliones, o Vilniaus miesto gyventojas vidutiniškai per dieną atlieka 2,6 keliones. $2012 \mathrm{~m}$. parengtame „Naujų transporto rūšių diegimo Vilniaus mieste" specialiajame plane (toliau - SP) Vilniaus Gedimino technikos universiteto (toliau - VGTU) tyrejai atliko gyventojų apklausą ir nustatè, kad šiuo metu atliekamų kelionių skaičius yra sumažèęs iki 2,3 kelionių, tokị mažèjimą lèmé per pastaruosius metus populiarèjanti internetinè prekyba.
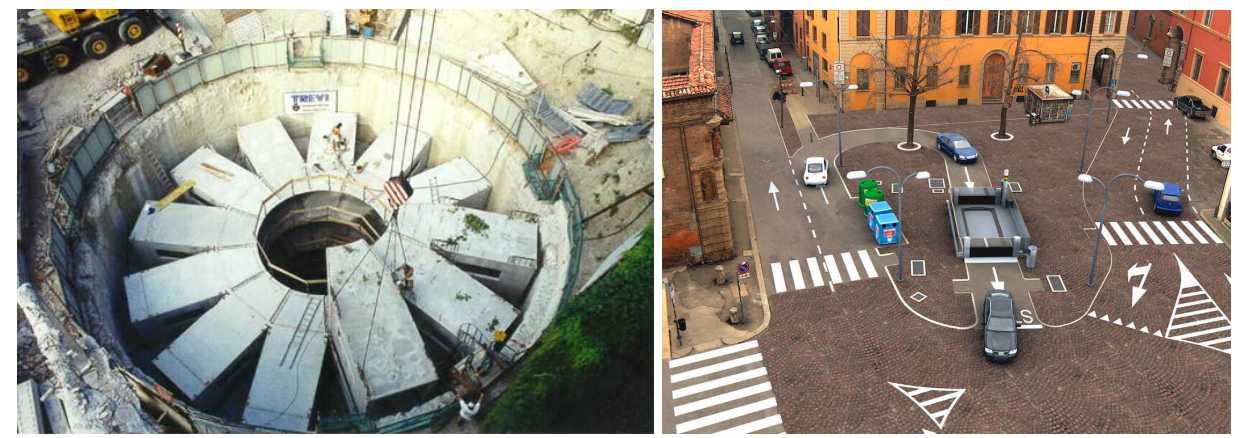

1.3 pav. Automatizuota požeminè automobilių stovejjimo aikštelè Bolonijos senamiestyje (Italija), kairëje - aikštelès statyba, dešinèje - veikianti požeminè aikštelè (nuotrauka: „Trevipark“)

Fig. 1.3. Automated underground car parking in the old town of Bologna (Italy), on the left - construction of car parking, on the right - functioning car parking (photo: Trevipark)

Europos didmiesčių gyventojai pavargo miestų centruose matyti ASA, kurios okupuoja teritorijas, skirtas viešosioms erdvèms, pėsčiųų ir dviračių takams. Vienai ASV reikia nuo $20 \mathrm{~m}^{2}$ iki $44,5 \mathrm{~m}^{2}$ ploto, vidutiniškai vienas vairuotojas kiekvieną dieną TP palieka mažiausiai du kartus skirtingose miesto ASA. ASV trūkumo poreikị miestų centruose bandyta spręsti statant daugiaaukštes, antžemines ir požemines ASA. Didejjančiam TP srautui buvo platinamos gatvès, kuriamas didelio eismo pralaidumo miestų gatvių tinklas, rekonstruojamos sankryžos ir kita. Nesvarbu, kiek naujų statinių LA stovejjimui ar greitkelių buvo pastatyta, transporto grūstys tik didejjo. Vadovèlinis pavyzdys - Los Andželas. Kartu su didejjančia automobilizacija miestų centre proporcingai buvo plètojamas jo gatvių tinklas ir aikštelès, kurių plotai dabar užima daugiau kaip $60 \%$ miesto teritorijos (Juškevičius et al. 2013). Galime teigti, kad kiekybiniai sprendimai neleido sumažinti LA skaičiaus miestų centruose, jie tik privede prie didesnių eismo grūsčių. Pasaulyje yra ir gerų pavyzdžių statant daugiaaukštes, antžemines ir požemines ASA, kurie miestui davė teigiamų rezultatų. Pavyzdžiui, Olandijoje, Breda miesto centre buvo nusausintas kanalas. Toje vietoje buvo pastatyta požeminè 200 vietų ASA. Vèliau miesto planuotojai ir gyventojai ėmè abejoti, ar viešųų erdvių atidavimas ASA yra išmintingas 
socialinès politikos sprendinys, ar skatinti naujų pastatų su ASV statybą buvo gera idejja. Ateitis parodè, kad vis dèlto toks drastiškas sprendinys pasiteisino, virš požeminès ASA buvo nutiesti nauji pėsčiujų takai. Vèliau Bredos miesto krantinèse buvo vykdomi ịvairūs projektai, kurie sulaukè pripažinimo iš gyventojų (Kodransky and Hermann 2011).

Visuotinai žinoma, kad kiekvieno LA kelionė prasideda ir baigiasi ASV, todèl ASV reglamentavimas yra vienas iš efektyviausių būdų reguliuoti LA naudojimą. Laisvos ASV paieškos dažnai sudaro didelę dalį visos kelionės laiko. Kita ASV politikos kryptis skatina atgaivinti miestų centruose biotransportą ir panaudoti ribotus SS infrastruktūros plotus dviračių takams ir ASV.

Zonose, kuriose prioritetas suteikiamas pėstiesiems, TP eismas gali būti ribojamas arba uždraustas, išskyrus specialiajam transportui (gaisrinėms, greitosios pagalbos ir policijos automobiliams) ir aptarnaujančiam (pavyzdžiui, prekių pristatymo) transportui tam tikru paros metu. LA judejimas yra ribojamas arba uždraustas istoriniuose miestų centruose ar populiariuosiuose prekybinėse gatvèse. Barselonos miesto Gracijos rajone igyvendintas vadinamas „Supermanzana“" projektas (Tello et al. 1997), kuris priverte eismą judèti išilgai zonos, kurioje prioritetas buvo suteiktas pestiesiems ir dviratininkams. LA stovėjimas zonoje yra griežtai draudžiamas ir tik su specialiais leidimais galima trumpam pastatyti LA. Šs draudimas taikomas siekiant mažinti išmetamujju teršalų kiekius centrinejje miesto dalyje. Tokio tipo strategija yra pritaikyta Miunchene (Fensterer et al. 2014), Londone (Atkinson et al. 2009), Milane (Invernizzi et al. 2011) ir dešimtyse kitų miestų. Tai tapo pagrindine LA stovejjimo politikos strategija, kuri pagrịsta teršiančių TP judejjimo miesto centre apribojimu.

Miestuose dominuojančios originalios VT keleivių SS palaipsniui prarado prioritetą. Pasikeitę žmonių gyvenimo būdo ịpročiai atlikti kelionę „,nuo durų iki durų“, mažejantis VT greitis, pasiekiamumas, komfortas ir kitos aplinkybès parodè, kad šiendiena miestų centruose 50 \% eismo grūsčių sukèlèjai yra patys vairuotojai (Kodransky and Hermann 2011), kurie važinejja ir ieško laisvos ar pigesnès ASV. Todèl didžiuosiuose Europos miestuose LA stovèjimo politika buvo perorientuota $\mathfrak{i}$ alternatyvius socialinius tikslus. Priimta LA stovejjimo reforma, nulemusi ES aplinkos oro kokybės gerinimo ar nacionalinị šiltnamio efektą sukeliančių dujų mažinimo politikos tikslų vykdymo kontrolę miestuose. Naujas LA stovejjimo politikos tikslas - sumažinti LA naudojimo poreikị. Londonui (Thompson and Berman 2012), Stokholmui (Börjesson et al. 2012; Schuitema et al. 2010), kai kuriems kitiems Europos miestams pavyko sumažinti transporto grūstis centre. Tai lèmé igyvendinta rinkliavų už LA stovèjimą strategija, kuri sumažino naudojimąsi LA. Tačiau daugelyje kitų pasaulio miestų dèmesys yra skiriamas įvairių ASV statinių ir ASA plètrai. 
XX a. 9-ojo dešimtmečio pradžioje buvo sukurtos liftinès ASA sistemos, valdomos automatizuotu ir mechaniniu būdu. Europoje viena garsiausių įmonè „Stolzer“, gaminanti liftines sistemas, ịsikūrusi Vokietijoje netoli Karlsrūjè miesto, Europoje ir JAV jau igyvendino 11 liftinès ASA sistemos projektus. Šios sistemos labiausiai paplitusios JAV, bet greitai populiareja ir Europoje. Šios ASA svarbiausias elementas - lifto konstrukcija, kuri gali būti valdoma rankiniu ir/arba automatizuotu būdu (1.4 pav.). ASA sistemos gali būti ịrengiamos šalia jau esamų statinių (PC, viešbučių, administracinių ir komercinių pastatų) arba atskirai (Chrest et al. 2001).

a)

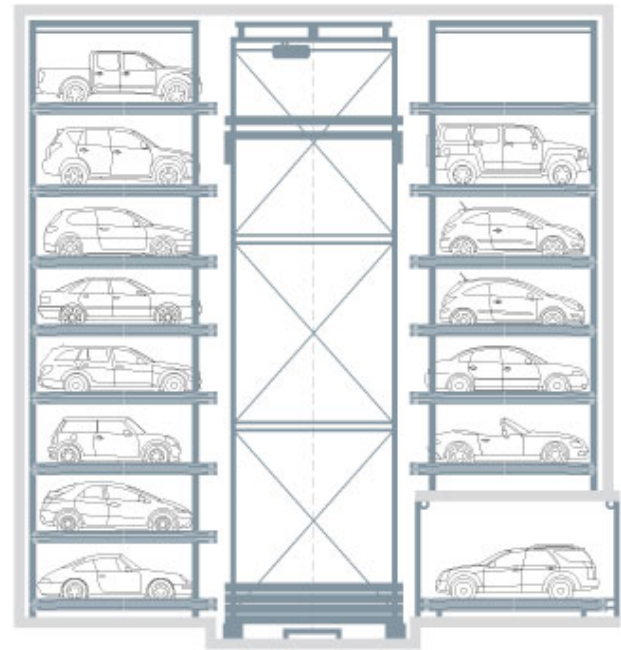

b)

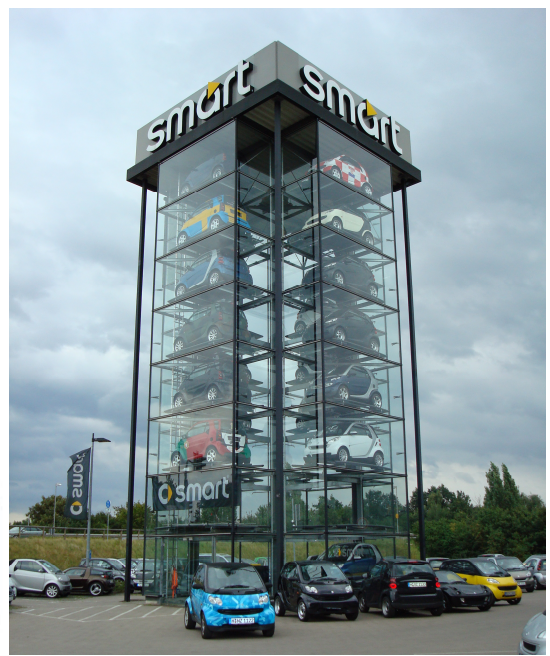

1.4 pav. Liftų konstrukcijos automobilių stovejjimo aikštelè:

$\mathrm{a}$ - liftinès sistemos schema (,Stolzer“), b - Hanoveryje (Vokietija) įrengtos liftų konstrukcijos ASA nuotrauka (autoriaus nuotrauka)

Fig. 1.4. Lifts construction's car parking: a - diagram of lift system (,Stolzer“), $\mathrm{b}$ - photo of equipped lifts construction's car parking (author's)

Aukščiausias leidžiamas liftinès ASA konstrukcijos aukštis gali siekti iki 20 metrų. Didžiausia ASA talpa iki 100 LA. Šios ASA statyba nėra brangi, bet reikalinga nuolatinė techninė priežiūra.

\subsubsection{Automobilių stovèjimo vietos vidurinèse miestų zonose}

Gyvenamųjų daugiabučių namų ASV normos Europos miestuose. Pasaulio miestuose unifikuotos ASV normos, jų skaičiavimo principai pamažu netenka vertès dèl objektyvių priežasčių: statinių ir urbanistinių kompleksų bei miesto struktūros funkcinių ir fizinių mutacijų, fizinio ir virtualaus mobilumo proporcijos raidos, gyventojų vidinès ir išorinès migracijos. Labai svarbūs 
veiksniai - finansinès miesto galimybès, kuro kainos, gyventojų mokumas (Juškevičius et al. 2013).

Daugumoje Europos miestų ASV normatyvų rengèjai nustatydavo minimalius ASV skaičiaus parametrus. Daugiabučiams namams buvo privaloma suprojektuoti bent po vieną ASV kiekvienam butui. Šiandien kai kurie pasaulio ir Europos miestai naikina minimalaus ASV skaičiaus reglamentų normatyvus ir pereina prie maksimalaus ASV skaičiaus politikos (Guo and Ren 2013; McDonnell et al. 2011; Rye and Ison 2007). Strategijos idejja grindžiama minimalaus ASV skaičiaus politikos trūkumais - kelionių LA skatinimas ir ASV paklausos didinimas (Shoup 1999). Minimalaus ASV skaičiaus politika yra perkeliama ant privataus sektoriaus pečių, tai yra investuotojams neapsimoka prie daugiabučiu namų ịrenginèti ASV pagal minimalius reikalavimus, nes iki 20 \% išauga statybos kaštai (Millard-Ball 2002).

Kai kurie Europos miestai pripažino, kad ASV maksimalios ribos nustatymas gali atnešti teigiamus pokyčius miestui. Ciurichas, Amsterdamas ir Strasbūras pirmauja igyvendinant šią iniciatyvą, bet daugelyje kitų miestų ši politika nèra igyvendinama ir vis dar yra naudojami senieji statybos reglamentai, pagrịsti minimalia ASV skaičiaus politika. Šveicarija, Jungtinė Karalystè ir Italija šią maksimalaus ASV skaičiaus politiką pritaike šalies mastu. Jungtinès Karalystės vietos jurisdikcijos privalo nustatyti maksimalius ASV parametrus, skatinant tvaraus transporto naudojimą, mažinant žemės ploto naudojimo plètrą, siekiant, kad sistemos tilptų ị centrinę miesto dalị, propaguojant kelionių tradicijas be LA bei kovojant su transporto grūstimis.

Ciuricho miestas igyvendino projektą „Sihlcity“ ir ịrodè, kad galima reguliuoti ASV paklausos pokyčius: skatinti gyventojus atlikti keliones VT, dviračiu ir pėsčiomis, o ASV buvo paliktos tik rajoną aptarnaujančioms TP ir neigaliesiems privažiuoti (Theurillat and Crevoisier 2013).

Paryžius atsisakè minimalaus ASV skaičiaus reglamentavimo ir kartu su keliais kitais miestai nustate pagrindinès zonos maksimumus. Papildomai jie ịvedė griežtą reglamentą, kuris neleidžia projektuoti ASA nutolusių toliau nei 500 metrų nuo VT sustojimo stotelių. Pavyzdžiui, Olandijos miestuose ASA reglamentavimas, kuris vadinamas „A, B, C“, buvo ịvestas $1989 \mathrm{~m}$. Miestai buvo suskirstyti $\mathfrak{i}$ trijų tipų zonas: A zona pasižymi puikia prieiga prie VT maršrutu ir prastu pasiekiamumu LA, B zonoje yra gerai išvystytas VT ir neblogos galimybès ją pasiekti LA, C zonoje geras pasiekiamumas LA, bet prastai išvystytas VT infrastruktūra. Kiekviena zona turi savo ASV skaičiaus maksimumus ir minimumus. Savivalda A zonoje siūlo sukurti naujas ASV, zonoje B taip pat galimas naujų vietų kūrimas, tačiau vietų skaičius turètų atitikti nurodytus intervalus, o zonoje $\mathrm{C}$ galimas ir tolimesnis ASV didinimas. Antverpenas ir Ciurichas taip pat sumažino ASV skaičiaus maksimalias ir minimalias reikšmes, kai jos įrengtos šalia pagrindinių VT maršrutų. 
Skirtingose Europos valstybėse, nustatant ASV normas, priimami skirtingi matavimo vienetai. Pavyzdžiui, Estijoje ir Danijoje ASV skaičius pateikiamas kvadratiniais metrais $\left(\mathrm{m}^{2}\right)$, Austrijoje ir Belgijoje ASV normatyvas skaičiuojamas pagal butų skaičių, Švedijoje ASV skaičius priklauso nuo kambarių skaičiaus (1.3 lentelè).

1.3 lentelè. Europos miestų automobilių stovejjimo vietų normos prie daugiabučių namų (Kodransky and Hermann 2011)

Table 1.3. Rates of car parking lots near apartment houses in European cities (Kodransky and Hermann 2011)

\begin{tabular}{|c|c|c|c|}
\hline Šalis & Miestas & ASV reglamentavimas & Papildomi reikalavimai \\
\hline Austrija & Viena & 1 ASV 1 butui & - \\
\hline Belgija & Antverpenas & 1,1 ASV 1 butui & $\begin{array}{l}2 \text { dviračių stovejjimo vietos } \\
1 \text { butui }\end{array}$ \\
\hline Danija & Kopenhaga & $1 \mathrm{ASV} 100 \mathrm{~m}^{2}$ & - \\
\hline Ispanija & Barselona & 1 ASV 2-6 butams & $\begin{array}{l}\text { ASV skaičius priklauso } \\
\text { nuo butų ploto }\end{array}$ \\
\hline Ispanija & Madridas & 1 ASV 1 butui & - \\
\hline Lietuva & Vilnius & $\begin{array}{l}\text { Pagal zonas, nuo } 0,5 \text { iki } 1 \\
\text { ASV } 1 \text { butui. }\end{array}$ & $\begin{array}{l}\text { II-oje ir III-ojoje zonose } \\
\text { leidžiama papildomai } 0,25 \\
\text { reikšme sumažinti ši } \\
\text { koeficientą. }\end{array}$ \\
\hline Olandija & Amsterdamas & 1 ASV 1 butui & $\begin{array}{l}\text { svečiams }+0,2 \text { ASV } 1 \\
\text { butui }\end{array}$ \\
\hline
\end{tabular}

0,5 ASV 1 butui, jeigu

butas arčiau negu 500

Prancūzija Strasbūras metrų iki VT stotelès, 1

ASV 1 butui, jeigu butas nutolęs daugiau kaip 500

metru

\begin{tabular}{llll}
\hline Švedija & Stokholmas & 0,14 ASV 1 kambariui & - \\
\hline \multirow{2}{*}{ Vokietija } & Hamburgas & $\begin{array}{l}0,2 \text { ASV, jeigu gyvena } \\
\text { centrineje miesto zonoje, } \\
0,8 \text { ASV ne centrineje } \\
\text { miesto zonoje. }\end{array}$ \\
\hline Vokietija & Miunchenas & 1 ASV 1 butui & - \\
\hline
\end{tabular}

Lietuvos miestuose statant daugiabutị namą vienam butui yra ịrengiama 1 ASV. Tačiau didieji Lietuvos miestai turi išskirtinę teisę mažinti ASV. 
Pavyzdžiui, Vilniaus miesto savivaldybės taryba $2012 \mathrm{~m}$. lapkričio 7 d. prièmé sprendimą Nr. 1-861 „Dèl Vilniaus miesto savivaldybės teritorijos suskirstymo ị zonas pagal nustatytus ASV skaičiaus koeficientus schemos, kompensavimo už neịrengtas ASV tvarkos aprašo ir pavyzdinès sutarties tvirtinimo“ ir Vilniaus miesto savivaldybès taryba patvirtino Vilniaus miesto savivaldybès teritorijos suskirstymo ì zonas pagal nustatytus ASV skaičiaus koeficientus schemą (1.5 pav.). Taip pat, buvo patvirtintas kompensavimo už neįrengtas ASV tvarkos aprašas ir kompensavimo už neįrengtas ASV pavyzdiné sutartis.

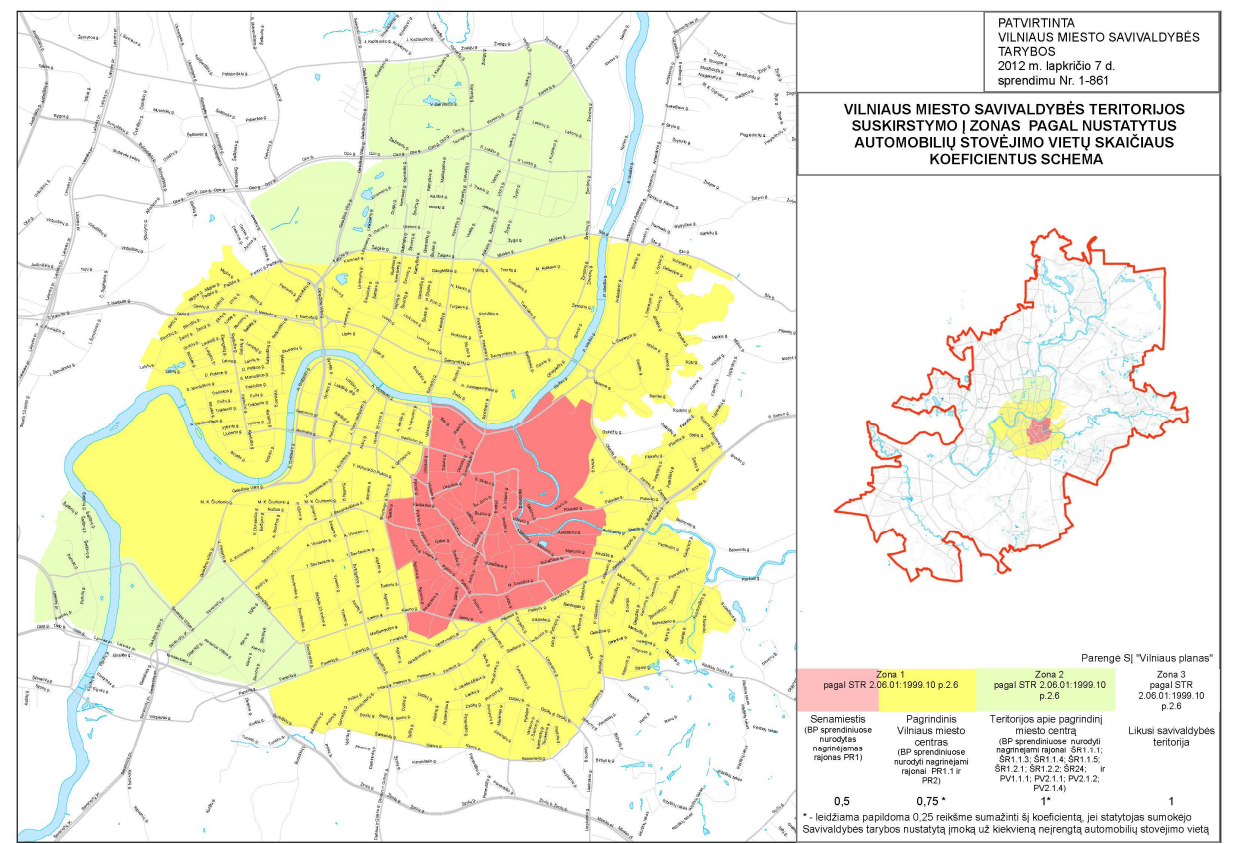

1.5 pav. Vilniaus miesto savivaldybès teritorijos suskirstymo ị zonas pagal nustatytus automobilių stovejjimo vietų skaičiaus koeficientus schema

Fig. 1.5. Scheme of zoning of Vilnius city municipality area according to the set rates of number of car parking spaces

Vadovaujantis Lietuvos Respublikos aplinkos ministro $1999 \mathrm{~m}$. kovo $2 \mathrm{~d}$. isakymu Nr. 61 patvirtinto Statybos techninio reglamento STR 2.06.01:1999 „Miestų, miestelių ir kaimų susisiekimo sistemos“ VI skyriaus „Automobilių aptarnavimo infrastruktūra“ 2.6 punktu, nustatyta, kad Savivaldybių tarybos savo sprendimais gali suskirstyti miestu ar miestelių teritorijas i zonas, nustatydamos jose ASV skaičiaus koeficientus ne mažesnius kaip: I-ojoje zonoje $-0,5$, II-ojoje zonoje $-0,75$ ir III-ojoje zonoje - 1 . Papildomai taryba prièmé 
sprendimą, kad II-ojoje ir III-ojoje zonose galima papildoma 0,25 reikšme sumažinti ASV, jei statytojas sumokès Savivaldybės tarybos nustatytą ịmoką už kiekvieną neįrengtą ASV, tai yra už 1 ASV 15000 Lt.

PC ASV reguliavimas. Europoje ir pasaulyje, PC ASA užima labai didelę miesto teritoriją. PC dažniausiai yra išdèstomi šalia pagrindinių miesto magistralinių gatvių, todèl yra labai patogūs atvykstantiems nuosavais LA. Dažniausiai PC ASA yra nemokamos, todèl natūraliai susidaro didelis ASA poreikis (Chu and Tsai 2011). Priešingai nei Europos šalyse, PC Lietuvos miestuose dažnai yra statomi gyvenamuosiuose rajonuose. Miegamuosiuose rajonuose esančios PC ASA moksliniu požiūriu yra mažai tyrinètos. PC ASA paskirti sunku tiksliai nusakyti, nes jos apibrěžtumas priklauso nuo ASV funkcionavimo kokybès, kuri nusako vienos ASV maksimalų LA skaičiaus panaudojimą per tam tikrą laiko vienetą. Šis rodiklis tiesiogiai proporcingas LA kiekio ir stovejjimo trukmès santykiui. Ilgiausiai miesto bendrojo naudojimo ASA stovi atvykusiujų i darbą LA. Esant ribotoms ASV, darbo dienos ryte atvažiavę aplinkinių objektų darbuotojai, gali užimti visas laisvas ASV ir visai darbo dienai sutrikdyti ASA funkcionalumą (Burinskiene and Paliulis 2003). Ypač daug klausimų iškyla, kaip kalbama apie PC ASA, kurios vertinamos kaip didelių traukos objektų aikštelès. Šių aikštelių problemos yra būdingos mišraus užstatymo teritorijose. PC, be maisto ir buitinių prekių parduotuvių, stengiamasi sutelkti kuo daugiau ịvairių prekių, paslaugų, pramogų įstaigų, bankų, draudimo, telekomunikacijų bendrovių parduotuves, vaistines, pašto skyrius ir kita. Šalia esančių daugiabučiu namų gyventojai bei atvykstantys svečiai PC ASA naudoja trumpalaikiam ir ilgalaikiam LA laikymui. Канаян (2005) nustate, kad pagrindiniai ASA naudotojai: darbuotojai, lankytojai ir gyventojai. Gali būti, kad tai neįvertinta priemonè AS procesui valdyti, todèl urbanistiniu požiūriu PC ASA privalumai leidžia ekonomiškiau naudoti miesto teritoriją bei sėkmingiau reguliuoti žmonių bei TP srautus (Mingardo and Van Meerkerk 2012).

Užsienio šalyse PC ASA reguliavimas buvo ilgą laiką grindžiamas ASV skaičiaus didinimo būdu: plečiant antžemines ASV ir statant daugiaaukštes bei požemines ASA. Kaip pavyzdi galime pateikti nuo 1985 m. Lenkijos miestuose prasidejusią PC statybą su daugiaaukštemis ir požeminèmis ASA. Varšuvoje (Pęski and Czechowski 2001), Krokuvoje (Kęsek 2007) ir kituose Lenkijos miestuose buvo pastatyti PC talpinantys ASA nuo 2000 iki 5000 LA, tačiau ilgainiui tokia ASA plètra sukèlè oro taršos ir padidinto transporto triukšmo lygio problemas. Šios problemos visuomenei buvo svarbesnès už ASV trūkumo problemas ir daugelyje Europos valstybių jos tapo prioritetinèmis. Vakarų Europos valstybès èmè spręsti oro taršos ir triukšmo problemas dviem pagrindiniais būdais: ribojant ASA dydị prie traukos centrų (ypač miestuose esančių PC) bei ịvedant mokestị už LA stovèjimą tokiose ASA. Pavyzdžiui, Helsinkyje (Suomija) yra ịvestas ASA dydžio apribojimas, kuris priklauso nuo 
objekto paskirties ir ploto. Skirtingoms miesto zonoms yra taikoma PC ASA dydžio priklausomybè nuo objekto ploto $\left(1\right.$ vieta $\left.\mathrm{LA} / \mathrm{m}^{2}\right)$ : centrinejje zonoje $1 / 200$, vidurineje zonoje $-1 / 150$ ir priemiestinejje miesto zonoje $-1 / 90-110$ (Klementschitz and Stark 2008).

Europos valstybėms - Suomijai, Danijai, Šveicarijai - yra ịprasta riboti PC ASA dydị. Pavyzdžiui, Kopenhagoje (Danija) naujai planuojamo PC investuotojai prašè valstybès institucijų leidimo statyti 12000 vietų ASA, bet leidimas buvo išduotas tik 3000 vietoms. Tokiu būdu yra sprendžiamos ne tik oro taršos ir triukšmo lygio problemos, bet ir skatinama naudotis VT paslaugomis. Taip pat, kai kurios Europos valstybès taiko mokestị už LA stovėjimo laiką prie PC. İdomus faktas, kad kai kuriuose Vokietijos miestuose valstybinès institucijos nustato mokesčio už LA stovèjimą dydi ir jo taikymo sąlygas. Pavyzdžiui, PC grąžina visą arba dalị už LA stovèjimą sumokètą mokestị, jeigu PC nupirkta prekių ar paslaugų bent už 1 euro centą arba PC nustatytą sumą. Šveicarija taip pat ịvedè tokị mokestį, bet sukèlè nepasitenkinimo bangą. Š Ł mokestị bandyta naikinti teismine tvarka, tačiau vèliau buvo pripažinta, kad toks mokestis atitinka teisès aktų reikalavimus. Nuspręsta, kad oro taršą reglamentuojantys teisès aktai turi būti laikomi aukštesniais už laisvosios rinkos principus, jeigu nustatytas mokestis už LA stovėjimą yra protingo dydžio (Klementschitz and Stark 2008).

PC ASA transportiniu požiūriu nèra plačiai nagrinèjama. Austrijos tyrinètojai natūriniais tyrimais nustate, kad prie PC vairuotojai nemažai laiko sugaišta ieškodami laisvos ASV. Todèl $2005 \mathrm{~m}$. Vienoje (Austrijoje) jie inicijavo PC lankytojų elgsenos tyrimus. Jame dalyvavo 700 respondentų, kurie buvo klausinejami $30 \mathrm{~min}$. Apklausos metu buvo pateikta daugybę klausimų apie PC vairuotojų reakciją ieškant ASA laisvos vietos, vairuotojų reakcija $\mathfrak{i}$ mokesčio už stovèjimą ịvedimas ir taip toliau. Atlikus apklausos analizę, buvo nustatyta, kad ịvedus 0,8 eurų mokestị už LA stovèjimą prie PC, $70 \%$ vairuotojų atsisakytų kelionès LA arba pasirinktų kitą PC, kuriame LA stovejjimo mokestis būtų mažesnis arba nemokamas. İvedus 1,3 euro mokestị PC lankytųsi $40 \%$ vairuotojų, o ịvedus 1,8 euro mokestị - $25 \%$ vairuotojų (Klementschitz and Stark 2008). Tačiau ne visi PC ryžtasi apmokestinti ASV, jie ieško pigių technologinių sprendimų padidinti esamą ASA talpą. Europos miestuose prie PC yra statomos modulinių konstrukcijų ASA, kurios leidžia greitai spręsti ASV trūkumą. Šios modulinès konstrukcijos ASA montuojamos prie oro uostų, komercinių objektų, gydymo ịstaigų ir kitur.

2010 m. Bristolio (Anglija) mieste prie PC „Asda“ pastatyta ASA talpinanti 297 LA (1.6 pav.). Šis projektas buvo naudingas PC, nes ASA yra $40 \%$ pigesnè už ịprastą daugiaaukštę aikštelę ir žymiai greičiau įrengiama. Pavyzdžiui, vieną aukštą galima sumontuoti per 50-60 dienų, o du aukštus per 90-120 dienų. Naudojama konstrukcija yra iš nerūdijančio plieno, ilgaamžè bei patvari, todèl 
tinka tiek trumpalaikiams, tiek ilgalaikiams sprendimams. Pagrindinis modulinès konstrukcijos privalumas: lengvai montuojami moduliniai konstrukcijos elementai, ilgaamžiškumas, minimalūs betonavimo darbai, ASA galima perkelti i kitą vietą ir net pakeisti jos išplanavimą. Esant poreikiui, visą konstrukciją galima išardyti i sudètinius modulius ir kitoje vietoje sumontuoti net ir kitos konfigūracijos aikštelę. Konstrukcijos lankstumas leidžia sukonstruoti ASA pačiose sudètingiausiose vietose. LA ịvažiavimo ir išvažiavimo rampas galima ịrengti ịvairiausiais būdais, apsaugant pėsčiuosius nuo intensyvaus eismo srautų.

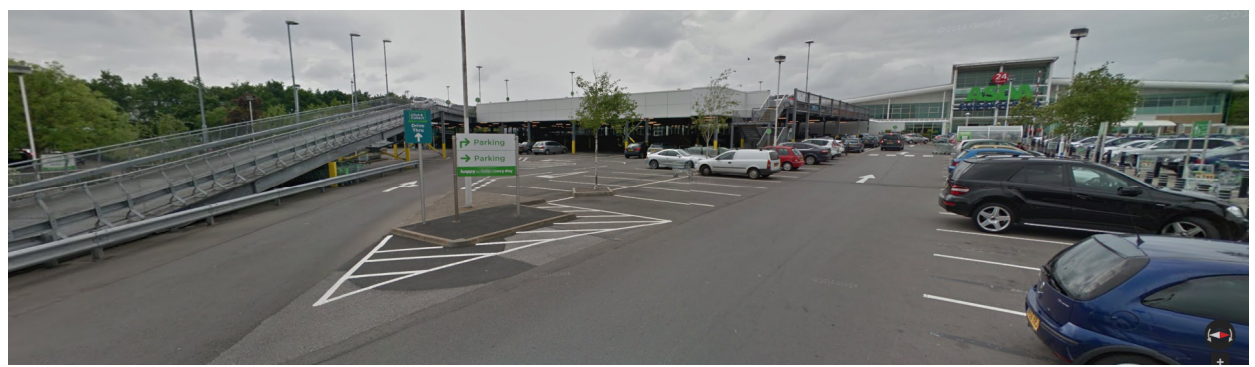

1.6 pav. Modulinė automobilių stovèjimo aikštelè (nuotrauka: https://www.google.lt/maps)

Fig. 1.6. Modular car parking (photo: https://www.google.lt/maps)

Modulinėse ASA galima ịrengti pakilimo ir nusileidimo pėstiesiems laiptus, apšvietimą, papildomas saugumo ir lietaus nuleidimo sistemas. Konstrukcijų moduliai yra tvirtinami specialiais vyriais, kiekvieną moduli tvirtinant prie kito. Moduliai jau būna paruošti ir sukonstruoti su iš anksto įdiegtais perimetro saugumo barjerais. Visos konstrukcijos standumo pagrindas yra teleskopinès kojos, kurios sureguliuojamos taip, kad būtų atsižvelgta ị skirtingus paviršius. Kadangi barjerai yra su turèklais, tai sudaro saugias darbo sąlygas vykdant statybos darbus. Teleskopines kojas ir rampas galima reguliuoti, atsižvelgiant $\mathfrak{i}$ vietovès reljefą.

\subsubsection{Automobilių stovèjimo vietos priemiestinèse miestų zonose}

Subalansuoto LA ir VT panaudojimas statyk ir važiuok (toliau - SV) principu. Pirmosios subalansuoto LA ir VT panaudojimo idejos iškeltos XX a. pirmoje pusèje. Jos kilo dèl privataus LA protegavimo politikos, kurios pasekmé - prisotinta miestų SS infrastruktūra, kuri sutrikdè VT veikimo efektyvumą, sumažino žmonių komunikacines galimybes ir kita.

1930 m. Detroito mieste (JAV), aštuoniose degalinèse atidarytos aštuonios mažos SV aikštelès, kurios išdėstytos šalia pagrindinių VT maršrutų. Tai buvo 
pirmasis bandymas mieste pritaikyti naują SV sistemą, bet nè viena aikštelè neturejo pasisekimo ir jas teko likviduoti. $1953 \mathrm{~m}$. Sent Luise (JAV), priemiestineje miesto zonoje, $8 \mathrm{~km}$ nuo verslo centro atidaryta nauja SV aikštelè, kuri galëjo sutalpinti iki 1000 LA. Nuo šios ASA iki verslo centro žmonès kelionę tęsdavo VT - autobusu (Christiansen et al. 1975). Sėkmingai igyvendinus SV sistemą, ji pradèta taikyti ir kituose JAV miestuose: $1955 \mathrm{~m}$. ši sistema įdiegta Manchetene (Frost 1974), 1963 m. Teksase, vėliau Čikagoje, Floridoje ir kitur. (Christiansen et al. 1975).

JAV pavyzdžiu, Europoje pirmieji miestai, kurie pradejjo taikyti SV sistemą buvo Oksfordas ir Lesteris (Anglija). Pasak SV sistemos tyrinètojo Cairns (1998), pirmasis eksperimentas nepavyko, nes ši sistema nebuvo patraukli potencialiems vartotojams. Pirmasis sèkmingas šios sistemos pritaikymas pripažintas $1970 \mathrm{~m}$. Notingeme, antrasis $1973 \mathrm{~m}$. Oksforde ir vèliau kituose miestuose. Anglijoje SV sistema tapo populiari, nes šią idèją ir sistemos plètrą palaikė ir skatino Vyriausybè, kuri siekè mieste sumažinti oro taršą ir automobilių srautus (Parkhurst and Richardson 2002; Khakbaz et al. 2013).

Užsienio šalių miestų patirtis rodo, jog LA gali būti ne pagrindinè miestuose naudojama susisiekimo TP ir sèkmingai gali būti kombinuojama su VT. Užsienio praktikoje SV sistemos veikimo principas - palikti LA priemiestinėje ar kitoje miesto zonoje ir toliau kelionę tęsti VT: metropolitenu, tramvajumi, troleibusu, autobusu, specialiu SV autobusu ir kitomis VT priemonemis (Clayton et al. 2013). Toks kelionès atlikimas leidžia dali gyventojų, važiuojančių LA, persodinti ì VT vykstant i miesto centrą. Pavyzdžiui, Roterdamo mieste (Olandija) buvo atliekamas SV aikštelèse tyrimas, kurio metu nustatyta, kad $90 \%$ vairuotojų i šias aikšteles atvažiuoja vieni. Taip pat nustatyta, kad 76,2 \% vairuotojų naudojasi šia aikštele darbo tikslais, 15,4 \% laisvalaikio ir $8,2 \%$ kitais tikslais. Roterdame SV aikštelių užimtumas darbo dienomis siekia 98,3 \%, o savaitgaliais 60,4 \% (Mingardo 2013).

SV sistemos ASA išsiskiria tuo, kad jos ịrengiamos greta išplètotų ir patogių keleiviams VT galinių stotelių arba prie specialiai nutiestos VT linijos. Informacija apie VT maršrutus pateikiama sistemos SV interneto svetainèse ir informaciniuose stenduose, kur yra nurodoma VT važiavimo kryptis, stotelès pavadinimas, kelionès trukmè, atvykimo ir išvykimo laikas, autobuso tipas ir kita.

SV aikštelès ịrengiamos prie pagrindinių gyventojų traukos objektų. Jeigu SV aikštelę aptarnauja specialus SV sistemos autobusas, tai jo maršruto dažnis yra nepriklausomas nuo esamo VT. Pavyzdžiui, Anglijos miestuose SV aikštelių aptarnaujančiu autobusų dažnis rytinio piko metu yra kas 10 min., nuo 10 val. ryto iki 16 val. vakaro, dažnis svyruoja nuo 10 iki 20 min., nuo 16 val. iki 18 val. - 10 min., o nuo 18 val. autobusų dažnis - 20 min. (Meek et al. 2011). Paprastai šios sistemos aikštelių paslaugomis galima naudotis tik darbo 
dienomis. Nakties metu ASA yra nenaudojamos. Kai kurios aikštelès naudojamos ir savaitgaliais arba didelių švenčių metu, pritaikant autobusų maršrutus link didžiujų miesto PC, stadionų, bažnyčių ir kitų traukos objektų, išvengiant ASV trūkumo ir grūsčių (Meek et al. 2010).

1.4 lentelè. Statyk ir važiuok sistema Europos miestuose

Table 1.4. Park and ride system in European cities

\begin{tabular}{|c|c|c|c|c|c|}
\hline $\mathrm{Nr}$. & $\begin{array}{c}\text { Miestas } \\
\text { (gyv. sk. mln. ) }\end{array}$ & $\begin{array}{c}\text { ASV } \\
\text { sk./talpa }\end{array}$ & $\begin{array}{l}\text { Darbo } \\
\text { laikas, } \\
\text { val. }\end{array}$ & $\begin{array}{c}\text { ASA } \\
\text { mokestis, } \\
\text { lt/diena }\end{array}$ & $\begin{array}{c}\mathrm{VT} \\
\text { mokestis, } \\
\text { lt/diena }\end{array}$ \\
\hline 1. & Liuksemburgas $(0,09)$ & $5 / 4166$ & n.d. & 0 & 10 \\
\hline 2. & Liubliana $(0,3)$ & $1 / 217$ & $6-20$ & 3,5 & 0 \\
\hline 3. & Sheffeld $(0,5)$ & $8 / 1754$ & n.d. & 16 & 0 \\
\hline 4. & Helsinkis $(0,6)$ & $27 / 3163$ & $\mathrm{~S}^{* *}$ & 7 & 15 \\
\hline 5 & Oslas $(0,6)$ & $5 / 3000$ & n.d. & 48 & 36 \\
\hline 6. & Amsterdamas $(0,7)$ & $5 / 1278$ & $7-22$ & 21 & $0^{*}$ \\
\hline 7. & Stokholmas $(0,8)$ & $22 / 3000$ & n.d. & 10 & 10 \\
\hline 8. & Kelnas $(1,0)$ & $28 / 5570$ & n.d. & 0 & 22 \\
\hline 9. & Praha $(1,2)$ & $17 / 3196$ & $4-1$ & 3,5 & 5 \\
\hline 10. & Miunchenas $(1,3)$ & $24 / 7128$ & 24 & 5 & 16 \\
\hline 11. & Ženeva $(1,3)$ & $19 / 4854$ & 24 & 126 & 26 \\
\hline 12. & Viena $(1,7)$ & $6 / 6226$ & 24 & 10 & 12 \\
\hline 13. & Budapeštas $(1,7)$ & $25 / 3384$ & n.d. & 3,5 & 7 \\
\hline 14. & Hamburgas $(1,8)$ & 49/9409 & n.d. & 0 & 18 \\
\hline 15. & Paryžius $(2,2)$ & $28 / 5849$ & $\mathrm{~S}^{*}$ & 43 & 11 \\
\hline 16. & Roma $(2,7)$ & $31 / 12880$ & n.d. & 10 & 7 \\
\hline 17. & Berlynas $(3,7)$ & $44 / 4947$ & n.d. & 0 & 19 \\
\hline
\end{tabular}

Pastabos: * - iki 5 asmenų, už aikštelès mokestị, S** - visų aikštelių darbo laikas skirtingas, n.d. nèra duomenų. 
Analizuojant Europos miestuose veikiančias SV sistemas, galima daryti išvadą, kad šios sistemos atsiradimo pagrindinès priežastys yra šios: transporto grūstys (Noel 1988; Karamychev and Van Reeven 2011), oro tarša (Dijk and Montalvo 2011) ir triukšmo lygis (Holguín-Veras et al. 2012).

Atlikus 17 miestų SV sistemos analizę, matyti, kad skirtingų Europos miestų SV sistemos planavimo strategija yra panaši, bet skirtingi jos veikimo ir taikymo principai. Pavyzdžiui, SV aikštelès yra ịrengiamos skirtingu tipų: ịprastos antžeminès, daugiaaukštès rampinès, modulinių konstrukcijų. Tai pat skirtinga ASA projektinė talpa, mokestis už ASV, ASA darbo laikas ir taip toliau (1.4 lentelè).

2012 m. VGTU tyrëjų parengtoje galimybių studijoje „Kombinuotų keleivių kelionių skatinimo, diegiant Park\&Ride, Bike\&Ride ir kitas koncepcijas, tyrimas" rašoma, kad Europoje pagal SV aikštelių skaičių tenkantị 1000 gyventojų pirmauja Liuksemburgas - 47,7/1000 gyv., o antroje vietoje Ženeva (Śveicarija) - 26,1/1000 gyv. Brangiausiai už sistemos panaudojimą moka šveicarai - 152 lt/diena, mažiausiai slovènai - 3,5 lt/diena. Sąlyginai nebrangi sistema Amsterdame (Olandija) - 21 lt/diena naudojantis iki 5 asmenų. Atvykus ị SV aikštelę 5 asmenims su vienu LA, visi gali VT keliauti nemokamai, t. y. už vieno LA mokestị SV aikštelèje.

Mokslinejje literatūroje rašoma, kad ne visur įdiegtos SV sistemos veikia efektyviai, todèl šios sistemos tyrinètojai siekia surasti optimaliausią variantą, kuris maksimizuotų potencialių SV aikštelių paklausą. Dauguma mokslininkų teigia, kad siekiant, kad kuo daugiau vairuotojų naudotųsi šios sistemos paslaugomis, kelionès VT santykis su LA turi skirtis kelis kartus. Taip pat SV sistemos paslaugos turi būti greitos, kokybiškos, autobusų maršrutai dažnis piko valandą iki 10 min. (Yushimito et al. 2012).

Olandijos SV sistemos tyrinètojas teigia, kad, planuojant įdiegti šią sistemą mieste, pirmiausia reikia atlikti išsamią SV sistemos ASA poreikio analizę. Todèl Mingardo (2013) siūlo mieste išskirti tris SV sistemos ASA kategorijas, kurios turi būti planuojamos atsižvelgus ị atstumą nuo miesto centro. Pirmajai kategorijai priskiriamos daugiausiai nutolusios nuo miesto centro SV sistemos aikštelès. Jos skirtos priemiestinèse teritorijose gyvenantiems žmonėms, kurie skatinami palikti LA aikštelèje ir toliau kelionę tęsti specialiu SV autobusu (Meek 2010). Antrajai kategorijai priskiriamos vidurineje miesto zonoje esančios SV aikštelès. Šių aikštelių sistemos modelis būdingas Anglijos ir JAV miestams ir jos tikslas yra nukreipti keleivių srautus iš galinių SV aikšteliu i miesto centrą (Chen et al. 2005). Trečiajai kategorijai priskiriamos vietinès SV sistemos ASA, kurios ịrengiamos šalia pagrindinių VT maršrutų. Šios aikštelès yra arčiausiai miesto centro, todèl jos dažniausiai ịrengiamos panaudojant esamų ASA infrastruktūrą, pavyzdžiui, PC, sporto ir pramogų kompleksų ASA arba irengiant naujas nedideles SV aikšteles. Ši sistema artima ryšio ir važiavimo 
(angl. Link and Ride) koncepcijai (Parkhurst 2000). Šios sistemos schema pateikta 1.7 paveiksle.

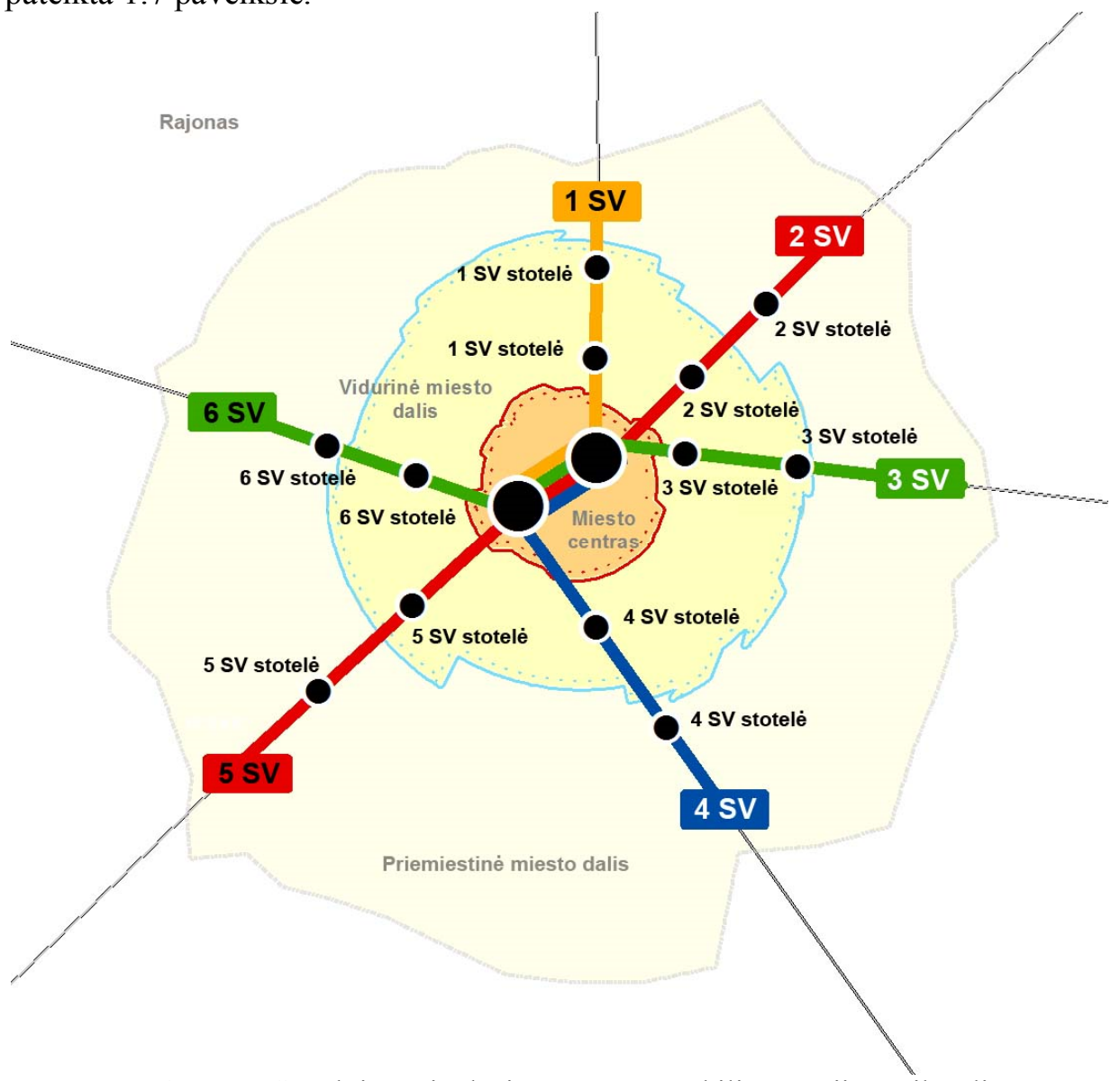

1.7 pav. Statyk ir važiuok sistemos automobilių stovejjimo aikštelių įrengimo rekomendacinè schema (sudaryta autoriaus)

Fig. 1.7. Guidance scheme of instaliation of park and ride system's car parking's (author's)

Užsienio praktika rodo, kad LA ir VT kombinuotos kelionès yra konkurencingos ir atitinka darnios transporto sistemos mieste reikalavimus. Ši sistema tenkina gyventojų, miestų savivaldybių ir VT paslaugos tiekejjų interesus. Dẻl šios sistemos mažeja LA eismas miestų centruose, didejja keleivių skaičius VT, auga bendras transporto srautu greitis, dideja eismo saugumas, gerinama miesto oro kokybė, mažinamas triukšmas ir taip toliau. 


\subsection{Kiti automobilių panaudojimo ir stovèjimo vietų mažinimo būdai}

Automobilizuotuose užsienio miestuose naudojamos ịvairios VT rūšys, taikant ịvairius eismo valdymo, eismo organizavimo ir kitus LA panaudojimo kelionèms ị miesto centrą mažinimo būdus. Tai originalios VT SS, veikiančios kaip tradicinio VT papildiniai, kurie leidžia sumažinti LA srautus centrinèje miesto dalyje, kartu sprendžiant oro kokybės ir transporto keliamo triukšmo lygio problemas. Neseniai VGTU mokslininkai atrado kitą būdą sumažinti TP keliamą triukšmo lygị. Jie Lietuvos klimato sąlygomis sumodeliavo tyliają asfalto dangą, kuri sumažina 2-4 decibelais triukšmo lygị (Vaitkus et al. 2014).

1.5 lentelè. Kiti automobilių panaudojimo ir stovèjimo vietų mažinimo būdai

Table 1.5. Other ways of reduction of car use and car parking lots

\begin{tabular}{|c|c|c|c|}
\hline Valstybė & $\begin{array}{l}\text { Kiti ASV mažinimo } \\
\text { būdas }\end{array}$ & Sistemos trūkumas & Sistemos privalumas \\
\hline JAV & $\begin{array}{l}\text { Bendro naudojimo LA } \\
\text { sistema }\end{array}$ & $\begin{array}{l}\text { Apribota } \\
\text { susisiekimo būdo } \\
\text { (pasirinkimo) laisvė }\end{array}$ & $\begin{array}{l}\text { Pigesnè kelionè i } \\
\text { darbą }\end{array}$ \\
\hline Vokietija & $\begin{array}{l}\text { Patobulinta bendro } \\
\text { naudojimo TP sistema } \\
\text { (iki } 15 \text { sédimų vietų) }\end{array}$ & $\begin{array}{l}\text { TP nepajëgi pervežti } \\
\text { didelị kiekị keleivių }\end{array}$ & $\begin{array}{l}\text { Nereikia stovèti } \\
\text { grūstyse, nes TP } \\
\text { važiuoja specialia } \\
\text { eismo juosta }\end{array}$ \\
\hline JAV & $\begin{array}{l}\text { VT iškvietimas } \\
\text { telefonu }\end{array}$ & $\begin{array}{l}\text { Gali naudotis tik } \\
\text { registruoti vartotojai } \\
\text { ir brangi kelione }\end{array}$ & $\begin{array}{l}\text { Didele VT } \\
\text { aptarnavimo teritorija }\end{array}$ \\
\hline Anglija & $\begin{array}{l}\text { Autobuso iškvietimas } \\
\text { telefonu }\end{array}$ & $\begin{array}{l}\text { Gali naudotis tik } \\
\text { senjorai ir neigalieji }\end{array}$ & $\begin{array}{l}\text { Autobusai yra } \\
\text { aprūpinti specialia } \\
\text { neịgaliesiems skirta } \\
\text { ịranga }\end{array}$ \\
\hline n.d. & $\begin{array}{l}\text { Autobusas dirbantis } \\
\text { nustatytu maršrutu }\end{array}$ & $\begin{array}{l}\text { Nežinoma maršruto } \\
\text { trukmé }\end{array}$ & $\begin{array}{l}\text { Pagal keleivių } \\
\text { pageidavimą gali } \\
\text { nukrypti nuo maršruto }\end{array}$ \\
\hline Iranas & $\begin{array}{l}\text { Maršrutinių taksi } \\
\text { sistema }\end{array}$ & $\begin{array}{l}\text { Nežinomas } \\
\text { maršruto laikas ir } \\
\text { dažnis }\end{array}$ & $\begin{array}{l}\text { Dirba nustatytu } \\
\text { maršrutu ir atsitiktiniu } \\
\text { dažniu bei sustojantys } \\
\text { pagal pageidavimą }\end{array}$ \\
\hline $\begin{array}{l}\text { Švedija, } \\
\text { Graikija }\end{array}$ & $\begin{array}{l}\text { LA lyginių ir } \\
\text { nelyginių numerių } \\
\text { ribojimas }\end{array}$ & $\begin{array}{l}\text { Nèra apribojamų } \\
\text { turintiems LA } \\
\text { vardinius } \\
\text { registravimo Nr. }\end{array}$ & $\begin{array}{l}2 \text { kartus sumažèja TP } \\
\text { srautas i miesto centrą }\end{array}$ \\
\hline
\end{tabular}


1.5 lentelès pabaiga

\begin{tabular}{llll}
\hline \multirow{5}{*}{ Vokietija } & Kiekvienam šeimos & Nemokamos miesto \\
& Parodyk techn. pasą ir & nariui reikia su & VT paslaugos visiems \\
& savimi turéti & šeimos nariams \\
& VT & $\begin{array}{l}\text { tapatybès liudijanti } \\
\text { dok., o vairuotojui } \\
\text { tech. pasą }\end{array}$ & \\
\hline
\end{tabular}

Gerai žinoma bendro LA naudojimo (angl. carpooling) sistema, kuri pradèta naudoti 1942 m. JAV. Vyriausybès priimtame teisès akte buvo nurodyta, kad privačių LA savininkai kelionèms ị darbą ir atgal turi naudoti bendrą LA. Ši sistema visuotinai neišpopuliarèjo, nes buvo apribota susisiekimo būdo (pasirinkimo) laisvè.

$1960 \mathrm{~m}$. pabaigoje bendro LA naudojimo sistema vèl atgimè. $1970 \mathrm{~m}$. igyvendinama nauja sistemos plètros strategija - bendros, iki 15 sẻdimų vietų, TP naudojimo (angl. vanpooling) programa. Jos atsiradimo priežastis buvo pagerinti susisiekimo kokybę nuo namų iki darbo, šią programą inicijavo JAV darbdaviai. Ji tapo populiari, nes šios TP talpino iki 15 žmonių (Chan and Shaheen 2012), miestuose buvo ịrengtos specialios eismo juostos (angl. HOV lanes), kuriomis buvo užtikrintas greitas važiavimas ir TP laidumas (Chu et al. 2012). Ši sistema išliko populiari iki šių dienų. Vokietijoje šios sistemos registruotų narių skaičius sudaro daugiau kaip 4 mln., o atliekamų kelioniu skaičius siekia 14 tūkst. per dieną (Arning et al. 2013). Lietuvoje bendro LA naudojimo sistema asocijuojasi su keliautoju, kuris laiko pakèlęs nykštị ị viršų ir stabdo TP, bet šiomis dienomis ši sistema technologiniu požiūriu stipriai pažengusi i priekị. Šiuolaikinè bendro LA naudojimo sistema veikia interaktyvios technologijos pagalba, kuri veikia išmaniuosiuose telefonuose GIS pagrindu (Dimitrijevic et al. 2013). Sistemos dalyvis turi turèti išmanujj telefoną, interneto ryši ir įdiegtą bendro LA naudojimo kelionès programą. Sistema veikia realiu laiku. Vairuotojai paskelbia savo kelionès maršrutą, keliautojai paskelbia apie pageidaujamą kelionę, nurodydami norimą išvykimo laiką. Programa automatiškai suporuoja sistemos dalyvius, kiekvienai pusei, kuri keliauja tuo pačiu maršrutu, persiunčia informaciją (Jiau et al. 2013).

Kita originali VT papildinio sistema - VT iškvietimas telefonu (angl. Dial a ride), kuris yra gana populiarus JAV. Vieša TP (taksi, mikroautobusas, autobusas) surenka ir išvežioja keleivius pagal jų užsakymus telefonu sudarytais maršrutais. Šis būdas buvo įteisintas 1968 m. JAV. Europoje ši SS praktiškai buvo patikrinta $1982 \mathrm{~m}$. Londone (Anglija). Londone nuo $1982 \mathrm{~m}$. iki šių dienų VT iškvietimo telefonu TP parkas išaugo iki 315 vienetų. Per $2013 \mathrm{~m}$. atliekamų kelionių skaičius siekė 1,3 mln., o registruotų vartotojų skaičius daugiau kaip 58000 (Weiner and Weiner 2013). Taip pat buvo pasiūlyta sistema, papildanti minètą SS - autobuso iškvietimas telefonu (angl. Dial a bus). Tai analogiška 
sistema, pritaikyta senjorams ir neiggaliems žmonėms pervežti. Pavyzdžiui, Londono (Anglija) Getviko oro uoste maždaug $1 \%$ visų atvykstančių keleivių reikalinga speciali pagalba. $2009 \mathrm{~m}$. duomenimis kiekvieną dieną 900 keleivių prireikè specialios pagalbos (Reinhardt et al. 2013).

Kai kuriose pasaulio valstybėse yra labai populiari SS panaši i maršrutinius taksi (angl. Jitney), jų talpa siekia nuo 5 iki 15 sėdimų vietų. Šios TP važiuoja nustatytu maršrutu, atsitiktiniu dažniu ir sustoja pagal pageidavimą. Pavyzdžiui, Irane šia sistema atliekama daugiau kaip $25 \%$ kelionių mieste (Gholami et al. 2014). Kita susisiekimo sistema - autobusas (angl. Fleksibus), dirbantis nustatytu maršrutu, tačiau pagal keleivių pageidavimą nuo jo nukrypsta. Ši sistema skirta ekstensyviai užstatytose teritorijose arba kaimo vietovèse gyvenantiems žmonėms (Juškevičius et al. 2013).

Švedijoje, o vèliau Graikijoje buvo pritaikytas nestandartinis ASV mažinimo būdas. Šio būdo esmè ta, kad darbo dienomis ịvažiuoti ị centrą gali LA su tam tikrais numeriais, pvz., LA, kurių numeriai baigiasi lyginiais skaičiais, gali ịvažiuoti lyginèmis dienomis, o nelyginiais - nelyginèmis dienomis.

2012 m. Leipcigo (Vokietija) miesto valdžia sẻkmingai įgyvendino projektą persodinti gyventojus iš LA ị tramvajus ir elektrinius traukinius. Jie prièmé sprendimą, jog visi LA vairuotojai, parodę LA technini pasą, gali VT važinèti nemokamai, ši lengvata galioja ir LA vairuotojo šeimos nariams.

\subsection{Inovatyvūs ir modernūs technologiniai automobilių stovèjimo statiniai}

Pirmoji pasaulyje daugiaaukštė (trijų aukštų) ASA buvo pastatyta 1902 m. JAV. Ši projektą organizavo ir finansavo Masačusetso automobilistų klubas (Steadman 2011). Apie 1920 m. JAV didieji miestai pirmą kartą susidūrè su TP grūsčiu problema. Reaguojant ị susidarusią situaciją, Los Andželo miesto centre, daugiausiai šalia PC, nuo $1923 \mathrm{~m}$. iki $1928 \mathrm{~m}$. buvo pastatytos 7 didelès ASA (Longstreth 1998). Auganti automobilizacija, mažejantis ASV skaičius miestuose paskatino kurti ir plètoti daugiaaukštes ASA, kurios buvo skirstomos pagal konstrukciją (vienaukščiai, daugiaaukščiai, antžeminiai, požeminiai), tipą (uždari, atviri, rampiniai, mechanizuoti), architektūrą ir pagal kitas statinio charakteristikas.

1956 m. architektas Goldberg sukūrè Marina miesto komplekso koncepciją. 1964 m. šis kompleksas buvo pastatytas Čikagoje (JAV) (1.8 pav. a). Tai buvo aukščiausias pasaulyje gelžbetoninis 65 aukštų gyvenamasis pastatas su daugiaaukšte ASA. Pastatas buvo pastatytas 179 metrų aukščio, jame iki 20 
aukšto įrengtos 896 ASV. Šio projekto igyvendinimas kainavo $36 \mathrm{mln}$. JAV doleriu (Rice 2011).
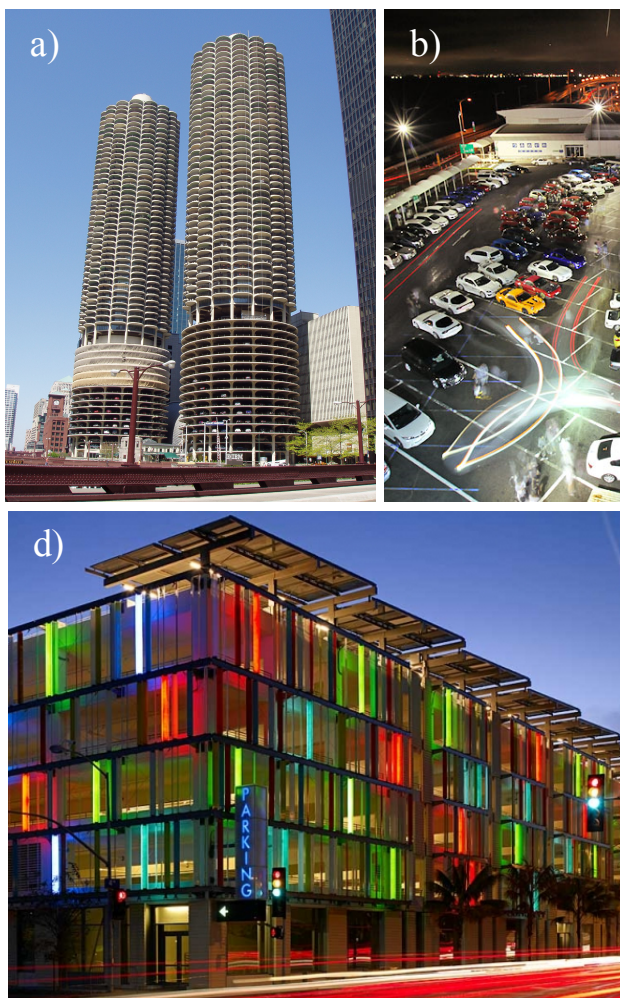
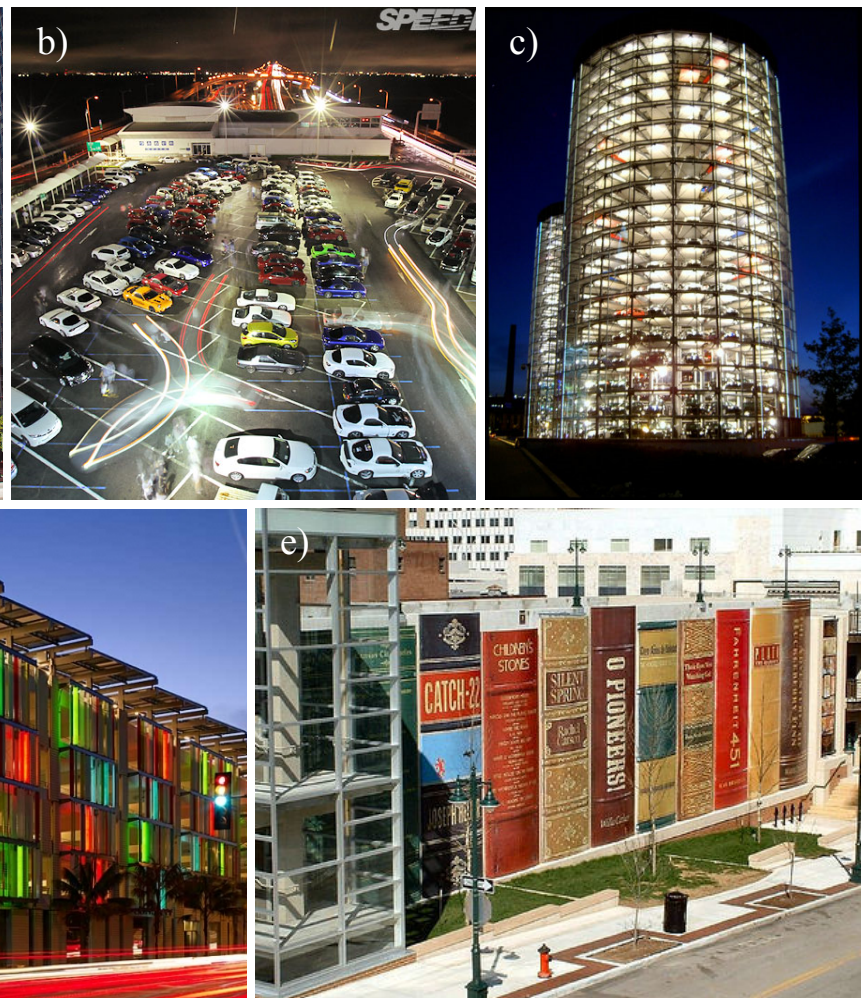

1.8 pav. Inovatyvios ir modernios automobilių stovèjimo aikštelès:

a) - Marina miesto kompleksas, b) - jūros jonvabalis, c) - bokštiniai garažai Volsburge, d) - šviesos diodo garažas Los Andžele, e) - garažas Kansase (Nuotr.: www.wikipedia.org)

Fig. 1.8. Inovative and modern technology structures:

a) - Marina city complex, b) - sea firefly, c) - rig garages in Volsburg,

d) - LED garage in Los Angeles, e) - garage in Kansas (Photo: www.wikipedia.org)

1968 m. Johnson užpatentavo mechanini bokštinį LA stovèjimui skirtą garažą. Nuo XX a. 7-ojo dešimtmečio prasidèjo bokštinių garažų statyba. Bokštinių garažų pasaulyje nèra daug, nes dèl sudètingos konstrukcijos ir architektūros jie yra labai brangūs. Labiausiai jie paplitę tarp LA gamintojų. 1994 m. Vokietijos LA bendrovė „Volkswagen“ pasamdè 400 architektų, kurie sukūrẻ 20 aukštų bokštinio garažo koncepciją. 2000 m. „Volkswagen“ du bokštinius garažus pastate Volsburgo mieste (Vokietija), šalia LA gamyklos. Šių 
garažų paskirtis - sandèliuoti ir reprezentuoti naujus LA, kuriuose ịdiegta inovatyvi ir moderni bei visiškai robotizuota LA sandèliavimo technologija (1.8 pav. c). Šio projekto verte $-435 \mathrm{mln}$. JAV eurų. Taip pat kvadrato formos bokštinis garažas pastatytas Hanoverio mieste (Vokietija), jis yra skirtas reprezentuoti ir sandèliuoti LA (1.4 pav.).

$2004 \mathrm{~m}$. Kansaso mieste (JAV) pastatyta ịspūdingos architektūros ASA. ASA primena knygomis apstatytą lentyną, kurioje demonstruojami 22 knygu pavadinimai (1.8 pav. e).

Brangiausias pasaulyje statinys, skirtas AS, pastatytas $2007 \mathrm{~m}$. Tokijuje (Japonija). Tai supilta dirbtinè sala, kurioje irengta plaukiojanti ASA (1.8 pav. b), vadinama jūros jonvabaliu (jap. Umihotaru). Sioje saloje ịrengti panoraminiai restoranai ir apžvalgos aikštelès. Šio projekto investicijos siekia 11,2 mlrd. dolerių, igyvendino trukmè daugiau kaip 30 metų.

2008 m. Los Andžele (JAV) Santa Monikos rajone pastatytas 900 vietų daugiaaukštė ASA, kurioje papildomai įdiegta 14 elektromobilių pakrovimo stotelių. Tai aplinkai draugiškas ir save išlaikanti ASA. Jame naudojama šviesos diodo (angl. LED) apšvietimas. Elektra yra generuojama saulès kolektoriais (1.8 pav. d).

\subsection{Automobilizacijos lygio raida Lietuvos miestuose}

Prieškariniais metais Lietuvoje TP skaičius siekẻ apie 3000, daugiausia motociklai, traktoriai, sunkvežimiai ir labai maža dalis - individualūs LA. Pokario metais èmé sparčiai didèti motociklų skaičius. 1970 m. Lietuvoje jų užregistruota daugiau kaip 230000 vienetų, o LA parkas ilgą laiką savo skaičiumi nusileisdavo motociklų skaičiui. $1950 \mathrm{~m}$. Lietuvoje buvo priregistruota 460 individualių LA. $1955 \mathrm{~m}$. LA skaičius išaugo 5 kartus ir jau siekè 2 400, 1965 m. - 18 100, 1970 m. - 32 700. XX a. 8-ojo dešimtmečio pradžioje automobilizacijos lygis Lietuvoje siekè 10 aut./1000 gyv., o motociklų - 50 moto./1000 gyv. (Adomavičius et al. 1984).

Nuo XX a. 8-ojo dešimtmečio Lietuvos miestuose pradejjo sparčiai augti automobilizacijos lygis. Palaipsniui miestuose atsirado TP perteklius, nes miestų susisiekimo infrastruktūra nespejo vystytis kartu su automobilizacija. Techniškai nepritaikytas gatvių tinklas, ASV trūkumas ir kitos aplinkybès paskatino atkreipti Lietuvos mokslininkų dėmesị ị šias problemas.

Pirmasis LA stovejjimo tyrimus vykdè bei problemas nagrinèjo VISI (dabar VGTU) Šeštokas (1973). Profesoriaus iniciatyva pirmieji individualių LA vairuotojų anketiniai tyrimai buvo atliekami $1979 \mathrm{~m}$. Kapsuke (dabar Marijampolè), Kalvarijoje ir Kazlų Rūdoje. Anketoje buvo pateikta 16 klausimų, liečiančių vairuotojų amžių ir socialinę būklę, metinę ridą, LA saugojimo 
sąlygas, keliones i darbą ir savaitgalio poilsio metu. $1984 \mathrm{~m}$. buvo atlikti pakartotiniai anketiniai tyrimai, kurie Lietuvos mokslininkams leido analizuoti individualaus LA panaudojimo charakteristikos pakitimus. İdomus faktas, kad tame dešimtmetyje mokslininkai nagrinejjo automobilizacijos lygio priklausomybę nuo miesto dydžio, nes pagal automobilizacijos lygị, tenkantị tūkstančiui gyventojų, Lietuvos mažieji miestai (Alytus, Marijampolè, Druskininkai, Utena, Palanga) lenkdavo didžiuosius miestus (Vilnius, Kaunas, Klaipėda, Šiauliai ir Panevėžys). Jeigu $1985 \mathrm{~m}$. didžiųjų miestų automobilizacijos lygis vidutiniškai sudarė 92 aut./1000 gyv., tai mažujų miestų - 102 aut./1000 gyv. Tai lemė skirtingas atstumas miestuose nuo namų iki darbo vietų. Mažuosiuose miesteliuose buvo mažai darbo vietų, todèl miesto gyventojai įsidarbindavo gretimuose miesteliuose ir apylinkèse. Pavyzdžiui, Kalvarijoje, kur vienam gyventojui vidutinis atstumas iki darbo siekdavo 5 kilometrus, ị darbą nuosavu LA važiuodavo 29,8 \% miestelio gyventojų.

Kitokia situacija buvo didžiuosiuose miestuose, kuriuose gerai išvystyta VT sistema buvo praktiškai vienintelis susisiekimo būdas. Apie $95 \%$ kelionių gyventojai ị darbą važiuodavo VT (Juškevičius et al. 2013). Maždaug po dešimties metų, kai Lietuva tapo nepriklausoma, masiškai i Lietuvą iš vakarų Europos pradèta importuoti naudotus LA.

$1993 \mathrm{~m}$. automobilizacijos lygis pasieké beveik 200 aut./1000 gyv., bet lyginant su vakaru Vokietija, automobilizacijos lygis Lietuvoje buvo 3 kartus mažesnis (Burinskienė and Munch 2003). Jau $2003 \mathrm{~m}$. VGTU mokslininkų publikuotame straipsnyje teigiama (Burinskienè and Paliulis 2003), kad Lietuvos automobilizacijos lygis viršijo 400 aut./1000 gyv. ribą ir 1999 m. parengtas statybinis techninis reglamentas STR 2.06.01:1999 „Miestų miestelių ir kaimų susisiekimo sistemos“ jau nepajègus reguliuoti AS procesų prie visuomeninių, komercinių ir pramoniniai kompleksų objektų, prie gyvenamųjų rajonų ir prie kitų ịvairių traukos objektų.

2006 m. Juškevičius su bendraautoriais, siekdami Klaipèdos mieste pagerinti ASV sistemą šiame mieste pasiekus 439 aut./1000 gyv. automobilizacijos lygi, pirmieji Lietuvoje patikslino LA stovejjimo vietų normas (Juškevičius et al. 2006). Šios normos skirtos ne tik Klaipeddos miestui, bet ir kitiems Lietuvos miestams, esant daugiau kaip 500 aut./1000 gyv. automobilizacijos lygiui.

$2012 \mathrm{~m}$. duomenimis, Lietuvoje buvo registruota daugiau kaip 1,6 mln. LA, o tai rodo, kad automobilizacijos lygis Lietuvoje yra 541 aut./1000 gyv. Tiketina, kad ateityje automobilizacijos lygis augs mažesniais tempais negu iki šiol, nes artejama prie santykinio prisotinimo ribos. Ivertinant Lietuvos socialinès ekonominès plètros tempus, automobilizacijos lygis neturètų išaugti daugiau kaip 600 aut./ 1000 gyv. (Juškevičius et al. 2006). 


\subsection{Norminių aktų, reglamentuojančių automobilių statymą, apžvalga}

Pirmuoju reglamentuojančiu LA stovejjimo vietų skaičių norminio akto pirmtaku Lietuvoje galime laikyti 1909 m. Paryžiuje (Prancūzija) pasirašytą „Tarptautine konvencija", kurioje buvo nustatyti pagrindiniai LA eismo organizavimo ir reguliavimo principai. Lietuvos miestuose augančiam LA parkui šios labai mažos apimties taisyklès (12 paragrafų) negalëjo užtikrinti kokybiškų LA reguliavimo principų, todèl jos buvo nuolatos tobulinamos ir keičiamos. $1926 \mathrm{~m}$. Lietuva pasirašė antrają „Tarptautinę keliu transporto konvencija“, kurioje LA reguliavimo principų reikalavimai aprašyti plačiau. $1931 \mathrm{~m}$. konvencija vėl buvo papildyta ir galiojo iki 1949 m., kai Ženevoje buvo pasirašytas Jungtinių Tautų Europos Ekonominès Komisijos vidaus transporto komiteto paruošta nauja jos redakcija, papildyta protokolu apie kelio ženklus ir signalus. Šis dokumentas tapo tipinėmis daugelio pasaulio šalių kelių eismo taisyklėmis, kurios suvienodino TP eismo tvarką pasaulyje.

Valstybinè teritorijų planavimo ir statybos inspekcijos prie Aplinkos ministerijos $2009 \mathrm{~m}$. sudarytame teisès aktų, reglamentavusių teritorijų planavimo, statybos ir valstybinès statybos kontrolès tvarką Lietuvoje 19471992 m., sąraše rašoma, kad po II-ojo pasaulinio karo, Sovietų sajungos okupacijos metais, pirmasis norminis aktas, reglamentuojantis AS, pasirode $1958 \mathrm{~m}$. gruodžio $1 \mathrm{~d}$. Ministru Tarybos nutarime $N r .570$ „Dél statybos vykdymo tvarkos ir dèl valstybinès statybos kontrolès ìvedimo kaimo vietovejje" (Žin., 1958, Nr. 23-114) rašoma, kad LA savininkai, norintys statyti LA laikyti skirtą garažą, gali tai atlikti tik gavę iš statybos valstybinès priežiūros tarnybos leidimą.

Sovietmečiu LA buvo nedaug, ji galèjo nusipirkti nusipelnęs ar ilgą eilę išlaukęs asmuo, gavęs profsajungos komiteto paskyrą. LA buvo labai brangus ir labai saugotinas prabangos daiktas, todèl ji ịsigijęs asmuo stengèsi pasistatyti garažą. Po šešerių metų $1964 \mathrm{~m}$. birželio 9 d. išéjo Ministrų Tarybos nutarimas Nr. 265 „Dèl garažu ir stovẻjimo aikšteliu individualiems automobiliams (motociklams) kooperatinés statybos plètimo " (Žin., 1964, Nr. 18-134), kuriame rašoma, kad tikslinga pradèti garažų ir ASA statybą, bet daugiausia kooperatiniais pagrindais. Statyboms paspartinti papildomai buvo patvirtinti garažų ir ASA statybos bei eksploatavimo kooperatyvo ịstatai, kuriuose rašoma, kad kooperatyvo nariai iki statybos pradžios turi įmokèti visą garažo kainą ir LA savininkui leidžiama statyti tik vieną garažą arba vieną ASV. Pirmą kartą sovietmečiu Lietuvos miestuose leista vykdomiesiems komitetams ir statybos organizacijoms ịtraukti ị kapitalinès statybos rangos planus kooperatinių garažų ir ASA statybą. Tais pačiais metais rugpjūčio $17 \mathrm{~d}$. išleistas ịsakymas $N r .95$ „Dèl garažu ir stovejimo aikšteliu individualiems automobiliams bei 
motociklams laikyti statybos bei eksploatavimo kooperatyvu“, kuriame rašoma, kad miestų ir rajonų vykdomųų komitetų kapitalinės statybos skyriai turi supažindinti visuomenę su pavyzdiniais garažų ir ASA statybų bei eksploatavimo kooperatyvo įstatais. Miestų ir rajonų vyriausiems architektams pavesta nugriauti nelegaliai pastatytus garažus ir pasiūlyti jų statytojams statyti garažus kooperatiniu būdu. Taip pat, architektai turi parinkti vietas kooperatinių garažų ir ASA statybai. Papildomai kapitalinès statybos skyriams pavesta užtikrinti kompleksišką atskirų kooperatinių garažų grupių statybą, o komunalinio ūkio statybos projektavimo institutui pavesta parengti kooperatinių garažų projektus, numatant galimybę juos blokuoti stambiais kompleksais.

Po aštuonerių metų patvirtinti nauji kooperatyvo pavyzdiniai ịstatai. 1972 m. birželio 27 d. Ministrų Taryba išleido naują nutarimą Nr. 195 „Dèl individualiu automobiliu garažu statybos ir mokamu stovejjimo aikšteliu irrengimo sutvarkymo" (Žin., 1972, Nr. 17-134), kuriame pavesta miestų ir rajonų vykdomiesiems komitetams parengti garažų ir mokamų ASA išdèstymo schemas. Taip pat šiame nutarime numatyta, kad turi būti atlikta visų garažų ir ASA inventorizacija. Visi objektai turi būti suregistruoti ir jų eksploataciją galima pradèti tik tada, kai leidimą eksploatacijai patvirtins valstybinè komisija. Didžiuosiuose Lietuvos miestuose (Vilniuje, Kaune, Klaipėdoje, Šiauliuose ir Panevėžyje) Buitinio gyventojų aptarnavimo ministerija kartu su miestų vykdomaisiais komitetais įsipareigojo ịrengti mokamas automobilių (motociklų) stovejjimo aikšteles miestų centruose ir masinio gyventojų susitelkimo vietose bei patvirtinti šių mokamų stovèjimo aikštelių naudojimo taisykles. Papildomai Ministrų taryba pavede Buitinio gyventojų aptarnavimo ministerijos statybos organizacijoms atlikti požeminių garažų statybos rangos darbus.

$1974 \mathrm{~m}$. oficialiais duomenimis Lietuvos miestų gatvėmis jau važinèjo daugiau kaip 56000 LA (Burinskienè and Munch 2003). Toks visuotinis individualaus LA paplitimas tarp ịtakingų ir turtingu gyventojų sudare galimybę savarankiškai (neteisètais būdais) kurti savo AS politiką daugiabučių namų gyvenamojoje aplinkoje. Nepaisant tuometinių ịstatymų ir draudimų, nemažai garažų savavališkai arba komunalinio ūkio tarnyboms neoficialiai leidus buvo pastatyta daugiabučių namų kiemuose ir kitose valstybinès žemès vietose, nesuteikiant statytojams žemès sklypų. Matydama, kad šiuose sklypuose pastatytų garažų ir ịrengtų ASA neįmanoma teisiškai ịregistruoti, Ministrų taryba 1974 m. rugpjūčio 13 d. patvirtino nutarimą $N r .292$ „,Dèl individualiu lengvuju automobiliu garažu naudojimo sutvarkymo "(Žin., 1974, Nr. 23-237), kuriame Taryba pavedè vykdomiesiems komitetams suteikti neịteisintų garažų ir ASA statytojams žemès sklypus. Statytojai užtikrino jų teisini įregistravimą, ịsteigdami garažų statybos kooperatyvus ir, vietoj neteisètai pastatytų garažų, irengè kooperatyvinius garažus. 
Valstybinis statybos reikalų komitetas (VSRK) $1975 \mathrm{~m}$. gegužès $26 \mathrm{~d}$. išleido įsakymą Nr. 129 „Dèl individualiu lengvuju automobiliu garažu ir automobiliu parkavimo aikšteliu statybos tvarkos pažeidimu“", kuriame nurodè miestų vyriausiems architektams ir rajonų architektams parengti individualių automobilių garažų ir ASA išdèstymo schemas. Leidimus galima buvo išduoti statyboms tik visiškai sutvarkius statybos dokumentaciją, priimti juos naudoti tik kruopščiai patikrinus statybos baigtumą ir kokybę. Papildomai architektams pavesta numatyti metalinių garažų statybos vietas. Vykdomiesiems komitetams nurodyta organizuoti tinkamą garažų ịrengimą ir atlikti jų inventorizaciją, bei teisiškai juos įregistruoti.

$1975 \mathrm{~m}$. birželio $25 \mathrm{~d}$. Ministrų tarybą išleido nutarimą $N r .228$ „Dèl priemonių individualinès statybos trūkumams pašalinti “ (Žin., 1975, Nr. 20-177) skirtą namų valdų savininkams. Asmenys, turintys savo vardu ịregistruotą nuosavą LA arba motociklą (arba jei jị turi jų šeimos narys), gali individualioje namų valdoje pasistatyti garažą iki $25 \mathrm{~m}^{2}$ ploto. Po aštuonerių metų, $1983 \mathrm{~m}$. rugpjūčio $5 \mathrm{~d}$. ta pati Taryba išleido naują nutarimą $N r .213$ „Dél individualinès statybos " (Žin., 1983, Nr. 24-251), leidžiantị visiems individualių namų valdų savininkams savo namų valdoje pasistatyti garažą iki $25 \mathrm{~m}^{2}$ ploto asmeniniam naudojimui.

1981 m. birželio 12 d. Ministru taryba nutarime Nr. 213 „Dèl Ministru Tarybos 1972 m. birželio 27 d. nutarimo Nr. 195 ,Dèl individualiu automobiliu garažu statybos ir mokamu stovejjimo aikšteliu ịrengimo sutvarkymo" papildymo " (Žin., 1981, Nr. 17-230) nurodè, kad metalinius garažus gaminančios įmonès ir organizacijos, kurios parduoda šiuos garažus, užsakovas ar pirkèjas turi pateikti vykdomojo komiteto leidimą garažo statybai. Kitą dieną Ministrų taryba nurodė, kad už mokamų LA ASA įrengimą yra atsakingi miestų ir rajonų vykdomieji komitetai, už jų eksploataciją atsakingos Buitinio gyventojų aptarnavimo ministerijos igaliotos organizacijos. Aikštelių tvarkymui finansavimas skiriamas iš miestų biudžeto lèšų. Ministrų taryba taip pat nurodé, kad, jeigu aikšteles eksploatuos Lietuvos automėgèjų draugija, finansavimas turi būti užtikrintas iš nuosavų lèšų, nutarimas Nr. 212 „Dèl Ministru Tarybos 1972 m. birželio 27 d. nutarimo Nr. 195 „Dèl individualiu automobiliu garažu statybos ir mokamu stovejjimo aikšteliu įrengimo sutvarkymo" 10 punkto pakeitimo" (Žin., 1977, Nr. 17-228).

1986 m. liepos 15 d. Ministrų taryba nutarime Nr. 249 „Dèl garažu statybos kooperatyvu“" (Žin., 1986, Nr. 21-228) nurodè, kad leidžiama asmeninių LA laikymui statyti sublokuotus, vieno ar daugiau aukštu antžeminius ir požeminius kooperatinius garažus, kurie turi būti statomi pagal projektavimo organizacijų parengtus projektus. Nepriklausomybès metais Lietuvos Vyriausybė $1991 \mathrm{~m}$. kovo 1 d. papildè sovietmečiu išleistą nutarimą $N r$. 83 „Dèl garažu statybos ir eksploatavimo kooperatyvu pavyzdiniu istatu“" (Žin., 1991, Nr. 10-273). Jame 
nurodyta, kad kooperatyvai steigiami vieno ar daugiau aukštų antžeminių, požeminių arba sublokuotų garažų statybai individualiems LA laikyti miestuose, miesto tipo ir kaimo gyvenvietėse.

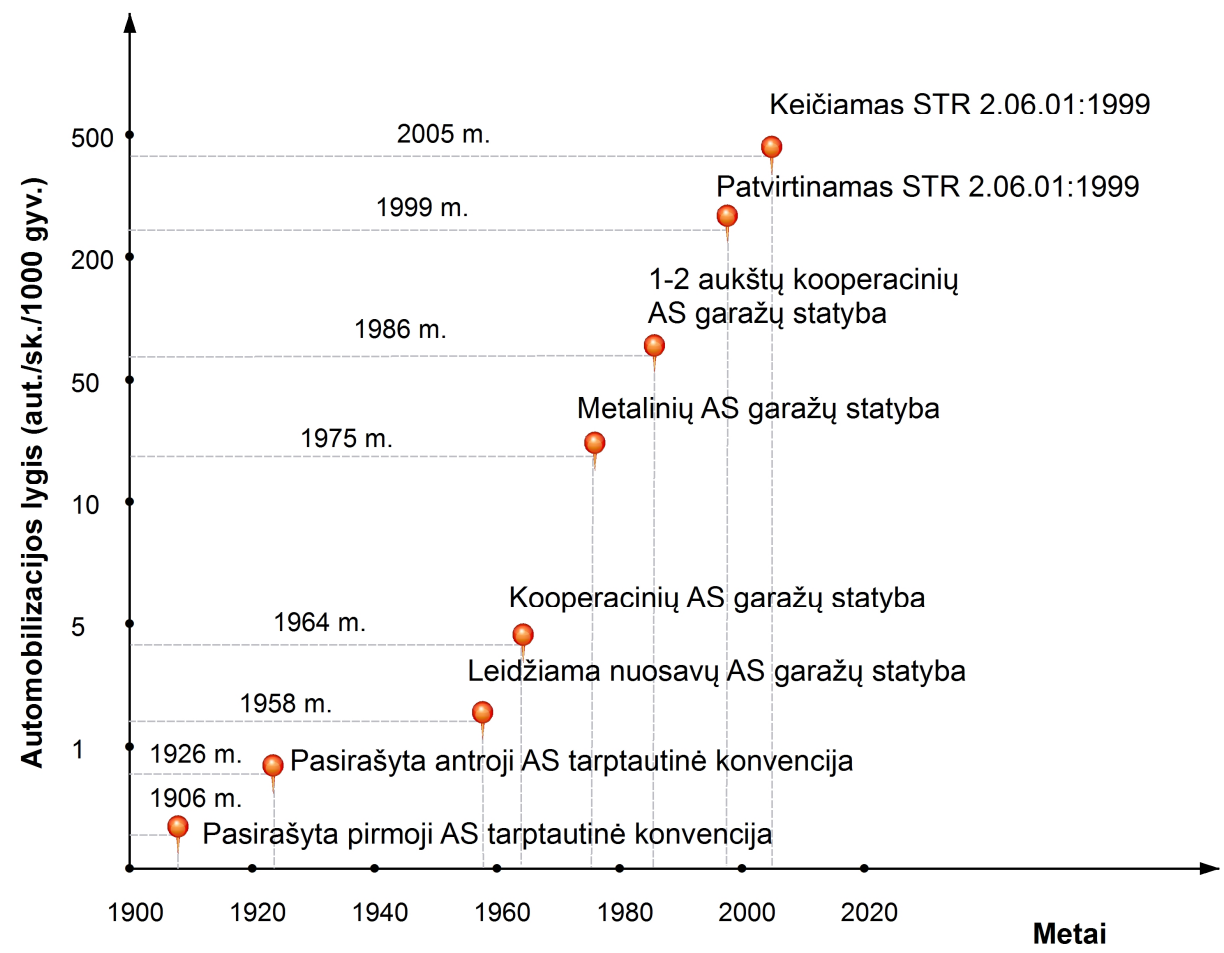

1.9 pav. Norminių teisès aktų, reglamentuojančių automobilių statymą, apžvalgos apibendrinta schema 1906-2005 m. (sudaryta autoriaus)

Fig. 1.9 Summary scheme of review of normative legal acts regulating car parking issues in 1906-2005 (author's)

Lietuvos Respublikos aplinkos ministro $1999 \mathrm{~m}$. kovo 2 d. isakymu $N r .61$ (Žin., 1999, Nr. 27-773) patvirtinamas Statybos techninis reglamentas STR 2.06.01:1999 „Miestų, miestelių ir kaimų susisiekimo sistemos“. Šis reglamentas parengtas remiantis geraja užsienio šalių praktika. Jame pateikiamas orientacinis ASA dydis, kai 1000 gyventojų tenka 400 LA. Reglamente nurodyta, kad naujai statomiems daugiabučiams namams turi būti įrengiama 0,8 automobilio vietos kiekvienam butui, iš jų $10 \%$ lankytojams. Prie PC turi būti ịrengiamos po vieną LA skirtą vietą nuo $20 \mathrm{~m}^{2}$ prekybos ploto, iš kurių $90 \%$ lankytojams ir taip toliau. 2005 m. kovo 21 d. ịsakymu Nr. D1-163 (Žin., 2005, Nr. 39-1285) buvo 
patikslinti ASV prie naujai statomų daugiabučių namų normatyvai. Nurodyta, kad prie jų kiekvienam $35-45 \mathrm{~m}^{2}$ butų naudingo ploto turi būti įrengiama 1 vieta LA. $2007 \mathrm{~m}$. sausio $31 \mathrm{~d}$. ịsakymu Nr. D1-73 (Žin., 2007, Nr. 16-596) vèl tikslinami ASV normatyvai prie naujai statomų daugiabučių namų. Reglamente nurodoma, kad turi būti ịrengiama 1 plius 0,2 ASV kiekvienam butui. Taip pat pabrèžiama, kad iki 0,2 ASV vienam butui gali būti ịrengiamos už statinio ar statinių grupès žemès sklypo ribų, bet ne toliau kaip $200 \mathrm{~m}$ nuo ịejjimų i šiuos namus. Śio normatyvo igyvendinimo ypatumus nustato savivaldybių tarybos savo sprendimais, planuojant teritorijas numatant atskirus sklypus automobilių saugykloms, galimybes ASV įrengti gatvių raudonųjų linijų ribose ir kitais būdais. Patikslintas statybos techninis reglamentas papiktino daugiabučius namus statančiu įmonių atstovus. Statybų verslo atstovai teigia, kad rengti šalia naujai statomų daugiabučių ASA neapsimoka, nes jau ir taip statybų kaštai yra dideli. $2008 \mathrm{~m}$. sausio $10 \mathrm{~d}$. ịsakymu Nr. D1-21 (Žin., 2008, Nr. 7-253) patvirtinami nauji ASV normatyvai, kuriuose nurodyta, kad prie naujai statomų daugiabučių namų turi būti ịrengiama 1 vieta kiekvienam butui. $2014 \mathrm{~m}$. parengiamas naujas STR 2.06.04:2014 „Gatvès ir vietinès reikšmés keliai. Bendrieji reikalavimai" projektas.

1.9 paveiksle pateikiama norminių teisès aktų, reglamentuojančių LA stovejjimo vietų klausimus nuo 1906 m., apžvalgos apibendrinta schema.

\subsection{Pirmojo skyriaus išvados ir disertacijos uždavinių formulavimas}

1. Analizuojant užsienio šalių patirtị nustatyta, kad automobilių stovejjimo vietų trūkumo problema atsirado XX a. 3 dešimtmetyje. Šiuo laikotarpiu pirmą kartą pasaulio istorijoje pradètas taikyti draudimas transporto priemones statyti centrinése miestų dalyse.

2. Nustatyta, kad užsienio šalių miestuose didžiausias dẻmesys skiriamas automobilių stovejjimo vietų apmokestinimui ir transporto priemonių judejjimo ribojimui centrinejje miesto dalyje. Vidurinejje miesto zonoje siūloma keisti automobilių stovejjimo vietų normatyvus iš minimaliai reikalingų stovejjimo vietų skaičiaus prie traukos objektų i maksimaliai leistinas reikšmes prie analogiškų objektų. Priemiestinejje miesto dalyje, siūloma diegti kombinuotų kelionių sistemas tokias kaip statyk ir važiuok, palik dvirati ir važiuok viešuoju transportu ir kita.

3. Mokslo darbų, skirtu automobilių stovejjimo vietų miestuose problemoms tirti, analizè parodè, kad užsienio šalių mokslininkai 
daugiausiai dèmesio skiria ekologiškų ir darnių transporto priemonių naudojimui ir jų stovejjimo vietų organizavimui. Dauguma mokslininkų teigia, kad automobilių stovejjimo vietų sprendimo būdai priklauso nuo vietos politikų strateginio požiūrio, finansinių miesto galimybių ir gyventojų mokumo, bet to neįrodinejja matematiškai.

4. Atlikus užsienio prekybos centrų automobilių stovejjimo aikštelių analizę pastebėta, kad tai lig šiol nevertinta priemonè automobilių statymo procesui valdyti. Urbanistiniu požiūriu prekybos centrų automobilių stovejjimo aikštelių antrinis panaudojimas leidžia taupiai naudoti miesto teritoriją bei sẻkmingai reguliuoti žmonių bei transporto priemonių srautus.

5. Susipažinus su užsienio šalių ir Lietuvos moksline literatūra, galima daryti išvadą, kad norint pagerinti automobilių stovejjimo vietų mieste panaudojimo efektyvumą, būtina atlikti šiuos veiksmus:

a) atlikti automobilių stovejjimo vietų natūrinius tyrimus vidurineje miesto zonoje;

b) nustatyti ar prekybos centrų automobilių stovejjimo aikštelès gali būti naudojamos kaip rezervinès aikštelès daugiabučių namų gyventojų automobiliams laikyti;

c) racionaliau panaudoti automobilių stovèjimui skirtus žemès plotus, įdiegiant statyk ir važiuok sistemą. 



\section{Automobilių stovèjimo vietų teoriniai tyrimai ir analizè}

Skyriuje atlikti ASV tyrimai 8 daugiabučių namų gyvenamuosiuose rajonuose ir 49 PC ASA. Išnagrinètos Vilniaus miesto BP sprendiniuose nurodytos SV sistemos ASA potencialios įrengimo vietos. Atlikta ASV kriterijų apžvalga, nustatyti jų svoriai. SV sistemos ASA plètrai ịvertinti pasiūlytos $3 \mathrm{SV}$ sistemos koncepcijos ir SV sistemos ASA teorinis modelis, kuris gali būti taikomas planuojant ASA.

Šio skyriaus tema publikuotas straipsnis (Palevicius et al. 2013).

\subsection{Automobilių stovejjimo vietų tyrimo planas ir metodika}

\subsubsection{Tyrimo planas}

Lietuvoje didžiausios ASV trūkumo problemos kyla didžiuosiuose miestuose, todèl konkretus tyrimo objektas pasirinktas Vilniaus miestas.

ASV trūkumo problemoms spręsti yra viena iš sunkiausiai igyvendinamų statybos ir transporto uždavinių. Teoriškai, kiekvienam LA reikalingos dvi ASV: viena gyvenamajame rajone, kita mieste prie darbovietès. 


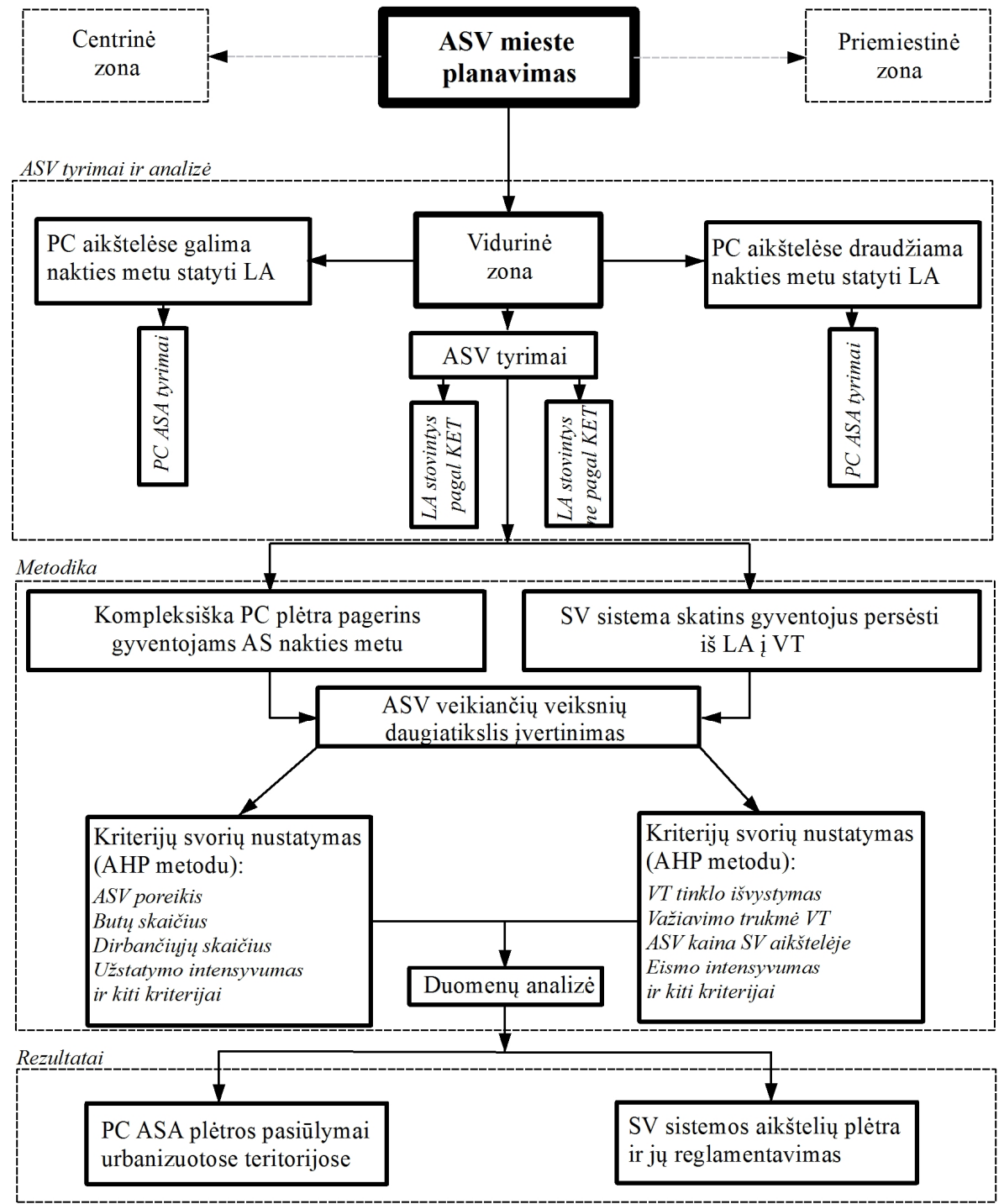

2.1 pav. Tyrimo vykdymo schema (sudaryta autoriaus)

Fig. 2.1. Scheme of assessment of the study (author's)

Vilniaus mieste LA vairuotojui 24 valandų laikotarpyje reikalingos 5-6 ASV (Adomavičius 1991). Todèl egzistuoja dvi LA laikymo problemos: ilgalaikis LA laikymas, kai LA stovi gyvenamajame rajone ir trumpalaikis, kai laikinai LA stovi mieste (prie darbovietės, PC, gydymo ịstaigos ir kitų traukos objektų). Kadangi šios dvi problemos viena su kita susijusios, tai jos turi būti 
sprendžiamos kartu. Šiam uždaviniui spręsti atliekami ASA tyrimai, kurių tikslas - nustatyti LA laikymo sąlygas daugiabučių namų ASV. Tyrimai vykdomi dviem etapais:

Pirmuoju etapu atliktas ASV tyrimas aštuoniuose gyvenamuosiuose rajonuose: Lazdynuose, Karoliniškèse, Viršuliškèse, Pilaitėje, Šeškinëje, Justiniškèse, Fabijoniškèse ir Pašilaičiuose. ASA esamai situacijai apibrěžti buvo atlikta momentinè stovinčių LA nuotrauka vakaro ir nakties metu (nuo 22 val. iki 6 val. ryto), esant maksimaliam ASV poreikiui.

Antruoju etapu atlikti 49 PC ASA tyrimai, kurie buvo įvykdyti tiriant ASA gyvenamuosiuose rajonuose. Tyrimo metu buvo pastebèta, kad daugiabučiu namų gyventojai grịžę iš darbų, LA palieka PC ASA. Atlikus šç tyrimą buvo nustatyta, kiek gyventojų naudojasi PC ASA ir nuo kokių veiksnių tai priklauso.

Papildomai buvo atlikta SV sistemos ASA ịrengimo galimybiu analizé Vilniaus mieste. Remiantis Vilniaus miesto BP sprendiniais, kuriuose pateiktos potencialios $33 \mathrm{SV}$ sistemos ASA įrengimo vietos, buvo įvertinta $3 \mathrm{SV}$ sistemos koncepcijos ir SV sistemos ASA teorinis modelis.

Tyrimų planas pateiktas 2.1 paveiksle.

\subsubsection{Stovinčių automobilių kiekio tyrimo metodai}

Sprendžiant ASV problemas miestuose, neišvengiama stovinčių LA kiekio tyrimų procedūra. Tyrimams atlikti taikomi ịvairūs būdai ir metodai. Juos lemia surinktos tyrimų medžiagos panaudojimo tikslai. Tyrimų rezultatai priklauso nuo surinktos informacijos patikimumo, tyrimų apimties, periodiškumo ir trukmès. Todèl tyrimams naudojami skirtingi metodai.

Paprasčiausias, bet daug laiko reikalaujantis, metodas - duomenų fiksavimas tyrimų registracijos lape. Tyrëjas gali naudoti dviejų tipų AS skirtus registracijos lapus: lentelès formos ir rastrinị pagrindą. Lentelès formos lape iš anksto laboratorijoje suklasifikuojama informacija stulpeliais, $\mathfrak{i}$ kuriuos tyrimo metu pildomi stebejjimo duomenys. Atlikus LA kiekio tyrimą, duomenys apdorojami laboratorijoje. Kitas būdas - tyrimų rezultatų žymëjimas rastriniame pagrinde (orto foto, topo ar kitame pagrinde). Šis būdas paprastesnis tyrimo pradžioje, nes tyrëjas gali lengvai orientuotis aplinkoje ir tyrimų metu išvengiama klaidų. Dažniausiai tyrimo objektas yra miestas, miesto seniūnijos arba kita didelè teritorija, todèl duomenų perkèlimas iš rastrinio pagrindo ị skaitmeninę aplinką pareikalauja labai daug laiko.

Siekiant nustatyti ASV funkcionavimo pobūdị, kurị nusako vienos TP stovèjimo vietos apyvarta (Burinskienè et al. 2011), naudojamas LA registravimo numerių metodas. Šio metodo tyrimo ribos dažniausiai yra PC ASA, senamiesčio ar kitų didžiųjų traukos objektų ASV. Natūrinis tyrimas vykdomas pagal laikrodžio rodyklę. Tyrejjas eina per visas ASV ir žymi 
stovinčių LA numerius registracijos lape, pabaigęs tyrimą, keliauja ị pradinị tyrimo tašką ir vẻl tokiu pačiu maršrutu sužymi LA numerius. Rekomenduojama prie PC ir centrinèse miesto dalyse tyrimus atlikinèti kas 15 minučių.

Vienas populiariausių metodų pasaulyje yra vairuotojų apklausos metodas, kurio atlikimas galimas žodžiu ir raštu. Naudojant ši metodą, teoriškai ir praktiškai galima gauti daugumą planuoti būtinos statistiškai patikimos ir reprezentatyvios informacijos. Svarbiausia, galima identifikuoti teritorinę problemų diferenciaciją. Ofiaciali statistika tokios galimybès neduoda, nes jos tiriamo objekto ribose nèra renkamas ir kaupiamas reikalingų duomenų sąrašas.

Pasitelkus aerofotografijos metodą galima vesti ASV apskaitą. Aerofotografija teikia galimybę ne tik užfiksuoti stovinčių LA skaičių, bet ir nustatyti vienos TP stovejjimo vietos apyvartą. Aeronuotrauka arba aerofotonuotrauka - tai žemès paviršiaus vaizdas, kuris nufotografuojamas iš skraidymo aparatų: palydovų, kosminių stočių, lèktuvų, oro balionų, dirižablių ir kita. Tačiau, šie fotografavimo būdai yra labai brangūs, todèl tyrejjai, ieškodami pigesnių būdų, sukūrè naują techniką, leidžiančią pigiau ir greičiau fotografuoti žemès paviršių. Pavyzdžiui, Lietuvoje naudojama šveicariška technologija „SenseFly eBee“. Tai profesionali aerofotogrametrinè sistema, skirta greitam ir tiksliam teritorijų kartografavimui. Lèktuvas pagamintas iš lankstaus putplasčio, kuris sveria tik 630 gramų. Tai pat, jame imontuota „eMotion 2“ programinė ịranga leidžianti planuoti, stebèti ir kontroliuoti lèktuvèlio skridimo trajektoriją skrydžio metu. Lèktuve įmontuota 16 megapikselių fotokamera, leidžianti skrendant daryti aukštos raiškos nuotraukas. Sugeneruotos ortofotografinès nuotraukos tikslumas gali siekti nuo 3 iki $30 \mathrm{~cm}$ viename pikselyje. Priklausomai nuo nuotraukų rezoliucijos ir pageidaujamo tikslumo, vieno skrydžio metu lëktuvas gali apskristi nuo $1,5 \mathrm{iki} 10 \mathrm{~km}^{2}$ teritorijos. Skraidymo laikas iki 45 minučių, skridimo greitis nuo 36 iki $57 \mathrm{~km} / \mathrm{h}$, atlaiko vejjo pasipriešinimą iki $12 \mathrm{~m} / \mathrm{s}$ (Metcalfe 2013). Šis metodas turi trūkumą - stovinčių LA kiekio tyrimus gali atlikti tik antžeminèse ASA (Huang and Wang 2010; Bhaskar et al. 2011; Wang et al. 2014).

Daugiaaukštėse ir požeminèse ASA naudojamos įvairios šiuolaikinès intelektualios automatinès AS registravimo sistemos. Jose gali būti ịdiegtos LA numerių atpažinimo sistemos, AS reguliavimo sistemos, sisteminès analizès ir apskaitos sistemos. Šiuo metu užsienio išradejjai kuria išmanias LA srautų valdymo sistemas, kurios padeda greičiau surasti automobiliui laisvą vietą (Shin and Jun 2014). Lietuvoje populiariausi LA numerių atpažinimo ir ASA apskaitos sistema - „eParkingas.1t“”.

Taip pat mokslinèje literatūroje galime rasti taikomą ekspertų metodą. Tai ekspertų apklausa, kurios svarbiausi požymiai yra susiję su reikalavimais ekspertų kvalifikacijos lygiui ịvertinti, būtinam jų skaičiui nustatyti, klausimyno 
turiniui, atsakymams ịvertinti ir analizei naudojant matematinę statistiką (Juškevičius et al. 2013).

\subsection{Automobilių stovèjimo vietų tyrimų seka ir rezultatai}

Prieš atliekant ASV tyrimus, buvo suformuluoti ir pagrịsti kriterijai, susieti su asmeninių kelionių ASV didmiestyje pasiskirstymo sistema (2.2 pav.). Atrinkti 26 kriterijai, iš kurių 8 kriterijai susieti su LA stovëjimo vietų poreikio nustatymu daugiabučių namų gyvenamajame rajone, 7 kriterijai susieti su PC ASA užpildymo rodiklių nustatymu ir 11 kriterijų susieti su SV sistemos ASA vietų parinkimu miesto teritorijose, kurių schema pateikta 2.2 paveiksle.

A. Gyvenamụjų rajonų automobiliụ stovèjimo aikštelių kriterijų svarbos tyrimas AHP metodu

A - Automobilizacijos lygis

$A_{2}^{1}-V T$ išvystymo lygis

$\mathrm{A}_{3}^{2}$ - Gyventojų tankis

$\mathrm{A}^{3}$ - Užstatytos teritorijos plotas

$A_{5}^{4}-$ Gyventojų skaičius

A - Gatvių tankis

$A_{7}^{6}-$ Darbo vietų skaičius

$\mathrm{A}_{8}^{7}$ - Dirbančiujų gyventojų skaičius

B. Prekybos centrų automobilių stovėjimo aikštelių kriterijų svarbos tyrimas AHP metodu

$\mathrm{B}_{1}$ - Užstatymo intensyvumas

$\mathrm{B}_{2}$ - Gatvių prie PC važiuojamosios juostos plotis

$B_{3}$ - Butų skaičius

$\mathrm{B}_{4}$ - Butų vertè

$\mathrm{B}_{5}$ - PC ASA tiesioginis matomumo atstumas iš aplinkinių butų

$B_{6}$ - Dirbantieji gyventojai

$\mathrm{B}_{7}^{6}$ - ASV poreikio koeficientas (reikiamu vietų skaičiaus santykis su turimų vietų skaičiumi)
AUTOMOBILIŲ STOVĖJIMO VIETŲ DIMIESTYJE KRITERIJUৃ SISTEMA

C. Statyk ir važiuok sistemos automobilių stovẻjimo aikštelių kriterijų svarbos tyrimas AHP metodu

$\mathrm{C}_{1}$ - SV sistemos ASA žemės kaina ir jos irengimo kaina

$\mathrm{C}_{2}$ - Eismo intensyvumas gatvèje šalia planuojamos SV sistemos ASA

$\mathrm{C}_{3}$ - VT maršrutų skaičius piko valandą $\mathrm{C}_{4}$ - Važiavimo trukmè VT

$\mathrm{C}_{5}$ - Vagysčių tikimybé ASA

$\mathrm{C}_{6}^{5}$ - Vairuotojų informavimo apie laisvas vietas informacine sistema

$\mathrm{C}_{7}$ - AS kaina SV sistemos ASA

$\mathrm{C}_{8}^{7}$ - LA ịvažiavimas ị SV aikštelę

$\mathrm{C}_{9}^{8}$ - Gatvių kategorija

C - Integruota LA ir važiavimo VT bilieto kaina $\mathrm{C}_{.11}^{10}-$ Vilniaus miesto BP numatytas užstatymo intensyvumas

2.2 pav. Automobilių stovèjimo vietų didmiestyje kriterijų grupių schema

Fig. 2.2. Scheme of groups of car parking lots criteria in metropolitan 
Kriterijai buvo suformuluoti ir padalinti ị tris grupes: 8 gyvenamujų rajonų (A grupè), 7 PC (B grupè) ir $11 \mathrm{SV}$ sistemos (C grupè) ASV kriterijai.

\subsubsection{Automobilių stovèjimo tyrimų rezultatai daugiabučių namų gyvenamuosiuose rajonuose}

Dabartinė Vilniaus miesto gyvenamųjų rajonų ASA infrastruktūra nepritaikyta esamam automobilizacijos lygiui, todèl vakarais, kai visi gyventojai grižta i namus, LA daugiabučių namų kiemuose labai dažnai paliekami neleistinose LA stovèti vietose. Daugiabučių namų gyvenamuosiuose rajonuose ASV natūrinis tyrimas buvo atliekamas nuo 20 val. vakaro iki 2 val. nakties. Stebejjimo metu buvo skaičiuojami visi LA, kurie buvo pastatyti vadovaujantis KET: ASA ir gatvėse bei nesivadovaujant KET: želdynuose, ant pėsčiųu ir dviračių takų, vaikų žaidimų aikštelèse ir kitose draudžiamose vietose. Tyrimo metu visos TP buvo žymimos iš anksto paruoštame topografiniame pagrinde.

Gauti stovinčių LA tyrimų rezultatai aštuoniose Vilniaus miesto daugiabučiu namų gyvenamųų rajonų teritorijose parodè, kad 10,2 \% LA stovi nesivadovaujant KET reikalavimais. Daugiausia neleistinose vietose stovinčių LA nustatyta Lazdynų rajone - 18,4 \%, identiška situacija Pilaitės, Šeškinès ir Justiniškių rajonuose - po $11,8 \%$, o mažiausiai neleistinoje vietoje stovinčių LA buvo Pašilaičių rajone $-4,6 \%$. Detalesni apibendrinti tyrimų rezultatai pateikti 2.1 lentelèje.

2.1 lentelė. Automobilių stovèjimo vietų tyrimų charakteristika Vilniaus miesto 8 gyvenamuosiuose rajonuose

Table 2.1. Characteristics of the study of car parking lots in 8 residental areas of Vilnius city

\begin{tabular}{|c|c|c|c|c|c|}
\hline \multirow[t]{2}{*}{$\begin{array}{l}\text { Eil. } \\
\text { Nr. }\end{array}$} & \multirow[t]{2}{*}{$\begin{array}{l}\text { Gyvenamas } \\
\text { rajonas }\end{array}$} & \multirow{2}{*}{$\begin{array}{l}\text { Stovinčiu } \\
\text { LA tankis, } \\
\text { aut/ha }\end{array}$} & \multirow{2}{*}{$\begin{array}{l}\text { Stovinčiu LA } \\
\text { tankis pagal } \\
\text { KET, aut/ha }\end{array}$} & \multicolumn{2}{|c|}{$\begin{array}{c}\text { Stovinčių LA tankis ir } \\
\text { procentinis pasiskirstymas } \\
\text { ne pagal KET }\end{array}$} \\
\hline & & & & aut./ha & $\%$ \\
\hline 1. & Lazdynai & 36,9 & 30,1 & 6,8 & 18,4 \\
\hline 2. & Karoliniškès & 35,2 & 32,9 & 2,3 & 6,5 \\
\hline 3. & Viršuliškès & 44,1 & 40,4 & 3,7 & 8,4 \\
\hline 4. & Pilaitė & 61,0 & 53,8 & 7,2 & 11,8 \\
\hline 5. & Šeškinė & 55,8 & 49,2 & 6,6 & 11,8 \\
\hline 6. & Justiniškès & 49,3 & 43,5 & 5,8 & 11,8 \\
\hline 7. & Fabijoniškès & 40,8 & 37,4 & 3,4 & 8,3 \\
\hline \multirow[t]{2}{*}{8.} & Pašilaičiai & 48,2 & 46,0 & 2,2 & 4,6 \\
\hline & Vidurkis: & 46,4 & 41,7 & 4,8 & 10,2 \\
\hline
\end{tabular}


Siekiant pagerinti ASV situaciją nagrinètuose aštuoniuose Vilniaus gyvenamuose rajonuose, esamą ASV skaičių reikia padidinti kelis kartus, tačiau tai padaryti sunkiai įmanoma. Tokiai ASV plètrai reikalingos didelès teritorijos ir finansinès lèšos.

\subsubsection{Gyvenamujjų rajonų automobilių stovėjimo aikštelių kiekybinių kriterijų svarbos tyrimas AHP metodu}

LA pastatymas ị jam skirtą vietą turi būti greitas ir patogus. Todèl svarbu pabrèžti, kad automobilių stovejjimo vietu tyrimų rezultatai neatspindi realios situacijos gyvenamųjų rajonų ASA. Atliekant tyrimą, iš pirmo žvilgsnio atrodo, kad dauguma LA stovi leistinu būdu. Tačiau daugiabučių namų kiemuose stovintis LA dažniausiai nesilaiko STR 2.06.01:1999 „Miestų, miestelių ir kaimų susisiekimo sistemos“ reikalavimų. Šiame statybos techniniame reglamente yra nurodyti LA stovejjimo būdai ASA: LA statomi lygiagrečiai su ịvažiavimu, statmenai įvažiavimui ir kita.

Pagal STR reikalavimus minimalus vienos ASV plotas aikštelèje turi būti $20 \mathrm{~m}^{2}$. Dažnas atvejis, kai vienoje ASV stovi du LA. Antrosios TP vairuotojas vèliau grịždamas ị namus nesivargindamas užstato pirmaji LA savininko TP. Taip pat aktuali problema egzistuoja Pašilaičių ir Fabijoniškių rajone, kai LA paliekami galinèse VT apsisukimo punktuose. Taip pat LA statomi įvažose skirtose specialiajam transportui, pavyzdžiui, šiukšlių surinkimo vietose, privažiavimų važiuojamojoje dalyje arčiau nei 10 metrų nuo gyvenamųjų namų ir panašiai.

Visą tai i̇vertintus, gyvenamuose rajonuose bendras neleistinose vietose stovinčių LA skaičius siekia iki $50 \%$, kas daro bendrą situaciją sudètinga ir sunkiai sprendžiama. Todèl galima daryti išvadą, kad LA stovejjimo tyrimuose, kaip ir daugelyje kitų pritaikomujų mokslo šakų, pagrindinis informacijos šaltinis yra natūrinis tyrimas. Tačiau šis tyrimas parodo ASV trūkumo mastą gyvenamajame rajone, todèl juo remiantis negalima toliau atlikti išsamios tyrimų analizès.

Atlikus natūrinius LA stovejimo tyrimus vietose, sudarytas LA stovejjimo vietų poreikị daugiabučių namų gyvenamuosiuose rajonuose lemiančių kriterijų sąrašas. Kriterijų sąrašas sudarytas ekspertizès būdu, tai yra mokslinio darbo vadovas ir disertantas kartu atrinko ir pateikè ekspertams kriterijus. Ekspertų grupę sudare teritorijų planavimo ir susisiekimo sistemu specialistai. Jie buvo parinkti atsižvelgiant i jų darbo stažą, tai yra darbo trukmè ne mažesnè nei 10 metų, ir patirti (Zavadskas et al. 2010a). Apklausti 9 ekspertai, kuriems pateikti 8 kriterijai (2.2 lentelè). 
2.2 lentelè. Atrinkti svarbiausi kriterijai, nuo kurių priklauso automobilių poreikis gyvenamuosiuose rajonuose

Table 2.2. Selected the most important criteria that affects the demand of cars in residental areas

\begin{tabular}{clc}
\hline $\begin{array}{c}\text { Kriterijaus } \\
\text { Nr. }\end{array}$ & \multicolumn{1}{c}{ Kriterijaus pavadinimas } & Matavimo vienetai \\
\hline $\mathrm{A}_{1}$ & Automobilizacijos lygis & LA sk./1000 gyv. \\
\hline $\mathrm{A}_{2}$ & VT išvystymo lygis & balai (nuo $1 \mathrm{iki}$ 9) \\
\hline $\mathrm{A}_{3}$ & Gyventojų tankis & tūkst. žm $/ \mathrm{ha}$ \\
\hline $\mathrm{A}_{4}$ & Užstatytos teritorijos plotas & ha \\
\hline $\mathrm{A}_{5}$ & Gyventojų skaičius & tūkst. vnt. \\
\hline $\mathrm{A}_{6}$ & Gatvių tankis & $\mathrm{km} / \mathrm{km}^{2}$ \\
\hline $\mathrm{A}_{7}$ & Darbo vietų skaičius & tūkst. vnt. \\
\hline $\mathrm{A}_{8}$ & Dirbančiụų gyventojų skaičius & tūkst. vnt. \\
\hline
\end{tabular}

Siekiant ịvertinti LA poreikị daugiabučių namų gyvenamuosiuose rajonuose, buvo nustatyti 8 kriterijai. Ekspertams buvo įteikta kriterijų porinio lyginimo anketa. Pirmojo eksperto užpildytas lyginimo matricos pavyzdys pateiktas 2.3 lentelèje.

2.3 lentelè. Pirmojo eksperto kriterijų porinio lyginimo pavyzdys

Table 2.3. Example of the first expert's pairwise comparison of indices

\begin{tabular}{ccccccccc}
\hline Kriterijų Nr. & $\mathrm{A}_{1}$ & $\mathrm{~A}_{2}$ & $\mathrm{~A}_{3}$ & $\mathrm{~A}_{4}$ & $\mathrm{~A}_{5}$ & $\mathrm{~A}_{6}$ & $\mathrm{~A}_{7}$ & $\mathrm{~A}_{8}$ \\
\hline $\mathrm{A}_{1}$ & 1 & 2 & 3 & 3 & 5 & 5 & 7 & 8 \\
\hline $\mathrm{A}_{2}$ & $1 / 2$ & 1 & 2 & 3 & 3 & 5 & 6 & 7 \\
\hline $\mathrm{A}_{3}$ & $1 / 3$ & $1 / 2$ & 1 & 2 & 3 & 3 & 5 & 6 \\
\hline $\mathrm{A}_{4}$ & $1 / 3$ & $1 / 3$ & $1 / 2$ & 1 & 1 & 3 & 3 & 5 \\
\hline $\mathrm{A}_{5}$ & $1 / 5$ & $1 / 3$ & $1 / 3$ & 1 & 1 & 1 & 3 & 3 \\
\hline $\mathrm{A}_{6}$ & $1 / 5$ & $1 / 5$ & $1 / 3$ & $1 / 3$ & 1 & 1 & 1 & 3 \\
\hline $\mathrm{A}_{7}$ & $1 / 7$ & $1 / 6$ & $1 / 5$ & $1 / 3$ & $1 / 3$ & 1 & 1 & 1 \\
\hline $\mathrm{A}_{8}$ & $1 / 8$ & $1 / 7$ & $1 / 6$ & $1 / 5$ & $1 / 3$ & $1 / 3$ & 1 & 1
\end{tabular}

Kriterijų svarbos nustatymui taikant sprendimų prièmimo sistemą svarbiausia yra nustatyti kriterijų reikšmingumą. Jam nustatyti taikomas T. Saaty sukurtas kriterijų porinio lyginimo metodas (Saaty 1980). Jis leidžia apskaičiuoti vieno lygio hierarchijos kriterijų svorius aukštesnio lygio atžvilgiu. Svorių nustatymui skaičiuojama pagal porinio lyginimo matricą:

$$
P=\left|p_{i j}\right|(i, j=1,2, \ldots, m) .
$$


Matricos $P$ elementai $p_{i j}$ - kriterijų nežinomųjų svorių santykiai. Ekspertai tarpusavyje lygina visus vertinamus kriterijus $R_{i}$ ir $R_{j}$, naudojant skalę 1-3-5-7$9, i, j=1,2, \ldots, m$, kur $m$ - lyginamų kriterijų skaičius. Matricos elementai kinta nuo 1, jei abu rodikliai yra vienodai svarbūs, iki 9, jei vienas rodiklis nepalyginamai svarbesnis už antrą. Matrica $P$ yra atvirkštinè simetrinè, tai yra $p_{i j}$ $=1 / p_{i j}$. Iš to išeina, kad galima pildyti matricos dalį, esančią virš pagrindinès įstrižainès arba po ja.

Saaty AHP metodo svoriai - vektorius $\omega$ yra tikrinio vektoriaus, atitinkančio didžiausiai matricos $P$ tikrinei reikšmei $\lambda_{\max }$ normalizuotos komponentès:

$$
P \omega=\lambda_{\text {max }} \omega .
$$

Kiekvieno eksperto atskiru vertinimų suderinamumo laipsni nustato suderinamumo indeksas (angl. the consistency index) C.I. ir suderinamumo santykis (angl. the consistency ratio) C.R.. Suderinamumo indeksas apibrèžtas (Saaty 1980) kaip santykis išreiškiamas formulę:

$$
\text { C.I. }=\frac{\lambda_{\max }-m}{m-1},
$$

čia $m$ - matricos eilè.

Matricos suderinamumas tuo geresnis, kuo mažesnè suderinamumo indekso reikšmè. Idealiu atveju C.I. $=0$.

Praktikoje matricos $P$ suderinamumo laipsni galima nustatyti, jei palyginti vertinimo matricos suskaičiuotą suderinamumo indeksą C.I. su tokios pat eilès atvirkštinès simetrinès matricos atsitiktinai sugeneruotos (pagal skalę 1-3-5-79) suderinamumo indeksu R.I. (Saaty 1980).

Konkrečios matricos suskaičiuoto suderinamumo indekso C.I. ir atsitiktinio indekso vidurkio R.I. santykis vadinasi suderinamumo santykiu ir vertina matricos suderinamumo laipsnị:

$$
\text { C.R. }=\frac{\text { C.I. }}{\text { R.I. }} .
$$

Matrica laikoma suderinta, kai suderinamumo santykis C.R. yra mažesnis už 0,1 (Saaty 1980):

$$
\text { C.R. } \leq 0,1 \text {. }
$$


Pirmojo eksperto AHP metodo suskaičiuoti kriterijų, nuo kurių priklauso LA poreikis gyvenamuosiuose rajonuose, svarbos rangavimo svoriai $\omega$ pateikti 2.4 lentelèje.

2.4 lentelè. Pirmojo eksperto analitinio hierarchinio proceso metodu suskaičiuoti kriterijų svoriai

Table 2.4. Weights calculated by the first expert using the analytic hierarchy process method

\begin{tabular}{lcccccccc}
\hline Kriterijų Nr. & $\mathrm{A}_{1}$ & $\mathrm{~A}_{2}$ & $\mathrm{~A}_{3}$ & $\mathrm{~A}_{4}$ & $\mathrm{~A}_{5}$ & $\mathrm{~A}_{6}$ & $\mathrm{~A}_{7}$ & $\mathrm{~A}_{8}$ \\
\hline Svoriai & 0,322 & 0,230 & 0,158 & 0,102 & 0,074 & 0,053 & 0,035 & 0,027 \\
\hline
\end{tabular}

Toliau pagal (2.1)-(2.5) formules apskaičiuojamas pirmojo eksperto lyginimo matricos tikrinè reikšmè $\lambda_{\max }=8,26$, suderinamumo indeksas C.I. $=0,037$, suderinamumo santykis $C . R .=0,026<0,1$. Gauti skaičiavimai rodo, kad eksperto vertinimai suderinti.

Ivertinus pirmojo eksperto vertinimų suderinamumą, toliau vertiname visos ekspertų grupès nuomonių suderinamumą. Ekspertų grupès nuomonių suderinamumo lygi nustato $W$ konkordancijos koeficientas (Kendall 1970) (1, $2, \ldots, r ; 1,2, \ldots, m)$, čia $r$ - ekspertų skaičius, $m$ - lyginamų kriterijų skaičius. Konkordancijos koeficientui skaičiuoti būtinas ekspertų kriterijų rangavimas. Vienodiems vertinimams priskiriamas tas pats rangas - eilinių rangu aritmetinis vidurkis.

AHP metodas, remdamasis kiekvieno eksperto palyginimo matrica, nustato kriterijų svorius $\omega_{i k}$, čia: $i=1,2, \ldots, m ; k=1,2, \ldots, r ; m$-lyginamų kriterijų skaičius; $r$ - ekspertų skaičius.

Pagal svorių mažejimą galima ranguoti kiekvieno eksperto vertinimus ir suskaičiuoti konkordancijos koeficientą. Kriterijų rangavimo rezultatai $e_{i k}$ pateikti 2.5 lentelèje.

Konkordancijos koeficiento $W$ skaičiavimui reikia žinoti: kiekvieno kriterijaus rangų sumą $e_{i}=\sum_{k=1}^{r} e_{i k}$; bendrą vidurkị $\bar{e}=\frac{\sum_{i=1}^{m} e_{i}}{m}$; dydžių $e_{i}$ nuokrypių nuo bendro vidurkio $\bar{e}$ kvadratų sumą $S=\sum_{i=1}^{m}\left(e_{i}-\bar{e}\right)^{2}$.

Radus visus reikiamus dydžius, toliau konkordancijos koeficientas $W$ skaičiuojamas pagal formulę (Kendall 1970; Евланов 1984):

$$
W=\frac{12 S}{r^{2} m\left(m^{2}-1\right)},
$$


čia $m$ - kriterijų skaičius; $r$-ekspertų skaičius.

2.5 lentelè. Kriterijų rangavimo matrica

Table 2.5. The matrix of the ranking of indices

\begin{tabular}{|c|c|c|c|c|c|c|c|c|c|c|c|c|}
\hline \multirow{2}{*}{$\begin{array}{l}\text { Kriterijaus } \\
\qquad \mathrm{Nr} .\end{array}$} & \multirow{2}{*}{ Kriterijai } & \multicolumn{9}{|c|}{ Ekspertai } & \multirow{2}{*}{$\begin{array}{l}\text { Rangų } \\
\text { sumos }\end{array}$} & \multirow[t]{2}{*}{ Vieta } \\
\hline & & 1 & 2 & 3 & 4 & 5 & 6 & 7 & 8 & 9 & & \\
\hline $\mathrm{A}_{1}$ & $\begin{array}{l}\text { Automobilizacijos } \\
\text { lygis }\end{array}$ & 1 & 1 & 2 & 1 & 1 & 3 & 1 & 1 & 1 & 12 & 1 \\
\hline $\mathrm{A}_{2}$ & $\begin{array}{l}\text { VT išvystymo } \\
\text { lygis }\end{array}$ & 2 & 3 & 3 & 2 & 2 & 1 & 2 & 3 & 2 & 20 & 2 \\
\hline $\mathrm{A}_{3}$ & Gyventojų tankis & 3 & 4 & 5 & 5 & 5 & 5 & 3 & 4 & 5 & 39 & 5 \\
\hline $\mathrm{A}_{4}$ & $\begin{array}{l}\text { Užstatytos } \\
\text { teritorijos plotas }\end{array}$ & 4 & 5 & 4 & 4 & 4 & 4 & 4 & 5 & 4 & 38 & 4 \\
\hline $\mathrm{A}_{5}$ & $\begin{array}{l}\text { Gyventojų } \\
\text { skaičius }\end{array}$ & 5 & 2 & 1 & 3 & 3 & 2 & 5 & 2 & 3 & 26 & 3 \\
\hline $\mathrm{A}_{6}$ & Gatvių tankis & 6 & 6 & 6 & 6 & 6 & 6 & 6 & 6 & 6 & 54 & 6 \\
\hline $\mathrm{A}_{7}$ & $\begin{array}{l}\text { Darbo vietų } \\
\text { skaičius }\end{array}$ & 7 & 7 & 7 & 7 & 7 & 7 & 7 & 7 & 7 & 63 & 7 \\
\hline $\mathrm{A}_{8}$ & $\begin{array}{l}\text { Dirbančiujų } \\
\text { gyventojų } \\
\text { skaičius }\end{array}$ & 8 & 8 & 8 & 8 & 8 & 8 & 8 & 8 & 8 & 72 & 8 \\
\hline
\end{tabular}

Konkordancijos koeficiento reikšmingumą ir grupès ekspertų vertinimų suderinamumą nustato kriterijus $\chi^{2}$ (Kendall 1970):

$$
\chi^{2}=W r(\mathrm{~m}-1)=\frac{12 \mathrm{~S}}{\mathrm{rm}(\mathrm{m}+1)} .
$$

Jeigu suskaičiuota pagal (2.7) formulę $\chi^{2}$ reikšmė didesnè už kritinę $\chi_{k r}{ }^{2}$ gaunamą iš $\chi^{2}$ skirstinio lentelès su $v=m-1$ laisvès laipsniu ir pasirinktu reikšmingumo lygmeniu $\alpha$ artimu nuliui, tai laikoma, kad ekspertų vertinimai suderinti.

Mano atveju esant bendram rangu vidurkiui $\bar{e}=40,5$, nuokrypių $\bar{e}_{i}$ kvadratu sumai $S=3132$, konkordancijos koeficientas $W=0,921$. Nors konkordancijos koeficientas palyginus nedidelis, suskaičiuota $\chi^{2}$ reikšmè $\chi^{2}=58$ didesnè už kritinę $\chi_{k r}^{2}=14,07$ su laisvès laipsniu $v=7$ ir reikšmingumo lygmeniu $\alpha=0,05$, todèl ekspertų nuomonès suderintos. 
Toliau kriterijų suskaičiuojami svoriai $\omega_{i}$ kaip visų ekspertų AHP svorių aritmetiniai vidurkiai:

$$
\omega_{i}=\frac{\sum_{k=1}^{r} \omega_{i k}}{r},
$$

čia $\omega_{i}-i$-jo kriterijaus $k$-jo eksperto suteikti normalizuoti svoriai, $r$ - ekspertu skaičius.

Remiantis (2.8) formule, suskaičiuoti visų 9 ekspertų suteiktiems aštuoniems kriterijams svorių reikšmès. Ekspertų kriterijų svorių reikšmių vidurkiai pateikti 2.6 lentelèje.

2.6 lentelė. Kriterijų svorių $\omega_{i}$ reikšmès nustatytos analitinio hierarchinio proceso metodu

Table 2.6. The values of weights $\omega_{i}$ of indices determined using analytic hierarchy process method

\begin{tabular}{ccccccccc}
\hline \multirow{2}{*}{ Ekspertai } & \multicolumn{7}{c}{ Kriterijai } \\
\cline { 2 - 9 } & $\mathrm{A}_{1}$ & $\mathrm{~A}_{2}$ & $\mathrm{~A}_{3}$ & $\mathrm{~A}_{4}$ & $\mathrm{~A}_{5}$ & $\mathrm{~A}_{6}$ & $\mathrm{~A}_{7}$ & $\mathrm{~A}_{8}$ \\
\hline 1 & 0,322 & 0,230 & 0,158 & 0,102 & 0,074 & 0,053 & 0,035 & 0,027 \\
\hline 2 & 0,275 & 0,179 & 0,122 & 0,074 & 0,230 & 0,048 & 0,039 & 0,034 \\
\hline 3 & 0,180 & 0,173 & 0,067 & 0,120 & 0,346 & 0,054 & 0,034 & 0,025 \\
\hline 4 & 0,307 & 0,169 & 0,144 & 0,123 & 0,108 & 0,065 & 0,058 & 0,025 \\
\hline 5 & 0,307 & 0,169 & 0,144 & 0,123 & 0,108 & 0,065 & 0,058 & 0,025 \\
\hline 6 & 0,177 & 0,349 & 0,070 & 0,093 & 0,192 & 0,062 & 0,036 & 0,021 \\
\hline 7 & 0,395 & 0,265 & 0,122 & 0,122 & 0,090 & 0,047 & 0,037 & 0,023 \\
\hline 8 & 0,270 & 0,190 & 0,116 & 0,068 & 0,219 & 0,065 & 0,042 & 0,030 \\
\hline 9 & 0,346 & 0,203 & 0,082 & 0,102 & 0,136 & 0,056 & 0,055 & 0,018 \\
\hline $\begin{array}{c}\text { Svoriu } \\
\text { vidurkiai } \\
\left(\omega_{i}\right)\end{array}$ & 0,287 & 0,214 & 0,114 & 0,103 & 0,167 & 0,057 & 0,044 & 0,025 \\
\hline \begin{tabular}{c} 
Vieta \\
\hline
\end{tabular} & 1 & 2 & 4 & 5 & 3 & 6 & 7 & 8 \\
\hline
\end{tabular}

Apskaičiuotos visų ekspertų kriterijų svorių reikšmės rodo (2.6 lentelè), kad LA poreikis gyvenamuosiuose rajonuose priklauso nuo automobilizacijos lygio $(0,287)$, VT išvystymo lygio gyvenamajame rajone $(0,214)$, gyventojų skaičiaus $(0,167)$ ir nuo kitų mažiau reikšmingų kriterijų. Apibendrintos kriterijų svorių reikšmès pavaizduotos 2.3 paveiksle. 


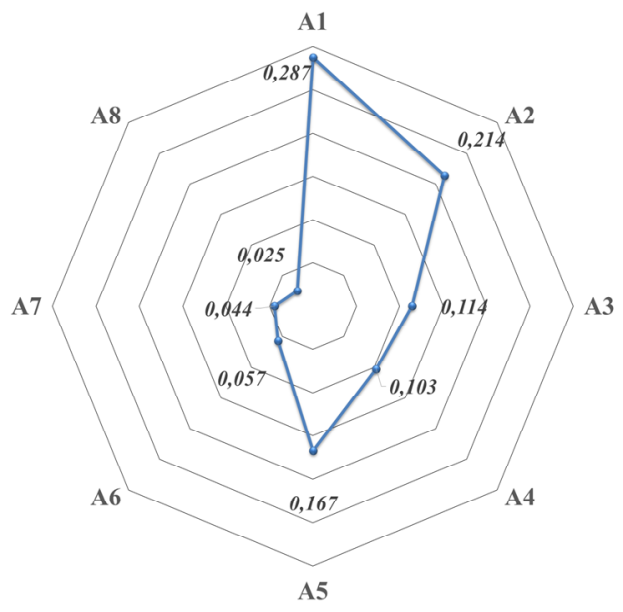

2.3 pav. Kriterijų svorių vidurkių $\omega_{i}$ reikšmės, nulemiančios kriterijų svarbą nustatant automobilių stovejjimo vietų poreiki gyvenamajame rajone (sudaryta autoriaus pagal 2.6 lentelę)

Fig. 2.3. Values of the criteria's weights averages $\omega_{i}$ determining importance of the criteria estimating the need for car parking lots in residential area (author's of table 2.6)

\subsubsection{Automobilių stovèjimo tyrimų rezultatai prekybos centrų automobilių stovèjimo aikštelèse}

Lietuvoje auganti ekonomika paskatino PC statybą. $1995 \mathrm{~m}$. Lietuvos stambiuosiuose miestuose atsidare pirmieji PC, kurie daugiausia buvo statomi vidurinèse miestų zonose. Intensyviausia PC statyba vyko 2000-2010 m., kai jų skaičius išaugo tris kartus. $2014 \mathrm{~m}$. duomenimis, Vilniuje bendras PC plotas sudarè daugiau kaip 400 tūkst. $\mathrm{m}^{2}$. Intensyvi plètra užtikrindavo gerą pasiekiamumą, prekių ir paslaugų įvairovę, nemokamas ASV. Dabartinis PC įvaizdis - didelès ASA, kurių centre yra vienaukštis centro pastatas. Tokia PC plètra pateisino investuotojų poreikius - pigiau ịsigyti žemę, nesudètingas projektavimas ir statyba, greitas investicijų atsipirkimas (Juškevičius et al. 2013). Jeigu PC leistų ASA funkcionuoti visą parą, iš dalies sumažintų draudžiamosiose vietose stovinčių LA disproporcijas daugiabučių namų kiemuose: sutrumpètų LA pastatymo i vietą paieška, pagertų oro tarša ir sumažètų triukšmo lygis. Todèl ASV tyrimams pasirinktos 49 PC ASA. 


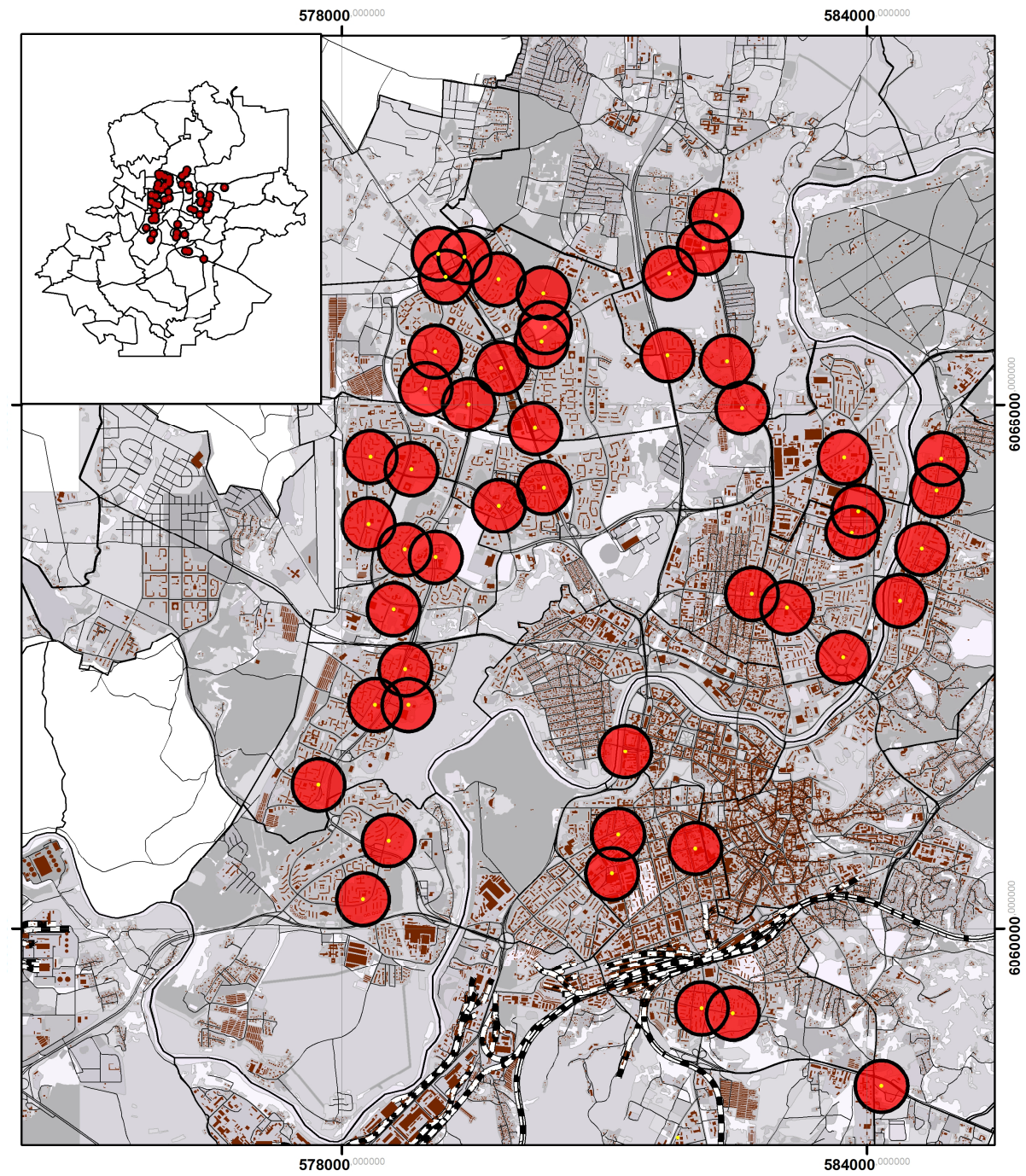

2.4 pav. 49 prekybos centrų automobilių stovejimo aikštelių tyrimų schema Vilniaus mieste $(\mathrm{R}=300 \mathrm{~m})$

Fig. 2.4. Research scheme of car parking's of 49 shopping centers in Vilnius city (radius $=300 \mathrm{~m}$ )

2013 m. rugsejjo ir spalio mėnesiais 49 PC ASA buvo atlikti stovinčiu LA natūriniai tyrimai (2.4 pav.). Stebejjimas buvo vykdomas nuo 22.00 val. vakaro iki 2.00 val. nakties. Šio tyrimo tikslas - nustatyti, ar PC ASA gali būti gyventojų naudojama kaip rezervuota ASA kai nedirba prekybos centrai ir kaip 
gauti tyrimų rezultatai gali būti panaudoti sprendžiant ASV trūkumą urbanizuotose teritorijose.

Svarbu paminèti, kad ASA gali efektyviai funkcionuoti, kai jos užimtumas neviršija $85 \%$. Esant didesniam užimtumui nei $85 \%$, aikštelès funkcionavimas yra apsunkintas, atsiranda eismo saugumo problemų, o kai viršija $100 \%$, stovejjimo procesas daugeliu atvejų tampa nevaldomas. Šị rodiklị galima reguliuoti, formuojant ir igyvendinant AS politiką, papildomai diegiant ASV reguliavimui informacines sistemas (Burinskiene et al. 2011).

Siekiant nustatyti PC ASA užpildymo reikšmę, tyrimų objektai (PC) buvo pasirinkti jau anksčiau tyrinètose teritorijose, tai yra aštuoniuose gyvenamuosiuose rajonuose: Lazdynuose, Karoliniškèse, Viršuliškejse, Pilaitėje, Šeškinèje, Justiniškèse, Fabijoniškèse ir Pašilaičiuose. Kadangi ASV trūkumas Vilniaus daugiaaukščių namų gyvenamuosiuose rajonuose gali būti išspręstas tik tuo atveju, jeigu rajonai bus perplanuoti ir pritaikyti prie esamos automobilizacijos, stebejjimo riba parinkta 300 metrų spinduliu $(\mathrm{R}=300)$ nuo PC ASA. Ši riba nustatyta remiantis STR 2.06.01:1999 „Miestų, miestelių ir kaimų susisiekimo sistemos", kuriame nurodyta, kad visos ASV prie tam tikro planuojamo statinio tam statiniui skirtame žemès sklype. Jei nėra techninių galimybių tai padaryti, ASV galima ịrengti ne toliau kaip 300 metrų atstumu nuo planuojamo statinio.

49 PC ASA užpildymo reikšmė buvo nustatoma pagal šią formulę:

$$
p_{s t .}=a-l+n .
$$

Čia $p_{s t .}$ - stovinčiu aikštelèje LA skaičius, $a$ - esamas ASV skaičius (ASA talpa), $l$ - laisvų ASV skaičius, $n$ - neleistinai stovinčių LA skaičius.

Atlikus skaičiavimus pagal (2.9) formulę nustatyta, kad bendra 49 PC ASA projektinè talpa yra 8776 ASV. Tačiau jose stovinčių LA skaičius nuo 22.00 val. vakaro iki 2.00 val. nakties buvo tik 2379 .

Toliau buvo skaičiuojamas ASA užpildymo rodiklis $(k)$, kuris reikalingas siekiant tam tikrais laiko intervalais nustatyti santyki tarp ASA stovinčių tam tikru laikotarpiu LA skaičiaus ir esamo ASV skaičiaus aikštelèje. Jis kiekvienai aikštelei buvo nustatomas pagal šią formulę:

$$
k=\frac{p_{s t .}}{a} \cdot 100 \% .
$$

Čia $k$ - ASA užpildymo (užimtumo) rodiklis, kintantis nuo 0 iki $100 \%$.

Apskaičiavus tyrimų duomenis pagal (2.10) formulę nustatyta, kad PC ASA nuo 22 val. vakaro iki 6 val. ryto LA užpildymas svyruoja nuo $1 \%$ iki $100 \%$. Tačiau buvo nustatytos ir dvi kuriozinès situacijos. Pirma, PC „Iki“ esančioje 
ASA (adresas: Laisvès pr. 31) stovejo 69 LA, bet ASA projektinè talpa tik 60 vietų. Šioje aikštelèje 9 LA stovèjo pažeisdami KET. Antra situacija nustatyta PC „Iki“ ASA (adresas: Didlaukio g. 80A), kai stovinčių LA skaičius 8 \% viršijo projektinę aikštelès talpą.

Buvo nustatyti PC, kurių ASA užpildymas LA siekė iki $5 \%$. Pavyzdžiui, Žirmūnų rajone esančiame PC „Maxima“ (adresas: Tuskulènų g. 66) ASA buvo nustatyti 6 stovintys LA. To priežastis ta, kad nuo 22 val. vakaro iki 8 val. ryto ịvestas 4 LT mokestis už 1 stovèjimo valandą. Kitas pavyzdys, Karoliniškių rajone esančiame PC „Maxima“ (adresas: Sausio 13-osios g. 2) 320 ASV talpinančioje aikštelèje suskaičiuoti 4 LA (užpildymas 1\%). Ši ASA yra nemokama, tačiau ji yra atskirta greito eismo gatve, jos beveik nesimato nuo gyvenamųjų daugiabučių namų ir tamsios paros metu ji nėra apšviesta.

Galima daryti išvadą, kad PC ASA, kurios dažniausiai vertinamos kaip didelių traukos objektų aikštelès, yra naudojamos daugiabučių namų gyventojų ilgalaikiam LA laikymui kai nedirba prekybos centrai. Šiuo metu Vilniaus mieste ASV skaičius prie esamu PC, įskaitant ir didžiausius prekybos ir pramogų centrus, siekia daugiau kaip 20000 vietų, iš kurių tik apie 5400 (27\%) yra užpildomos gyventojų LA nuo 22 val. vakaro iki 6 val. ryto (2.5 pav.).

a)

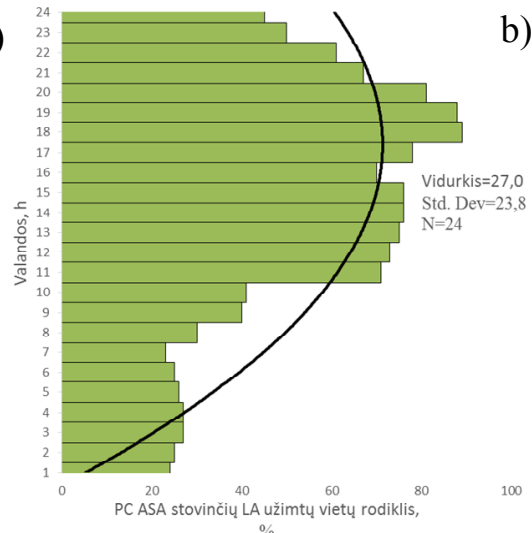

b)

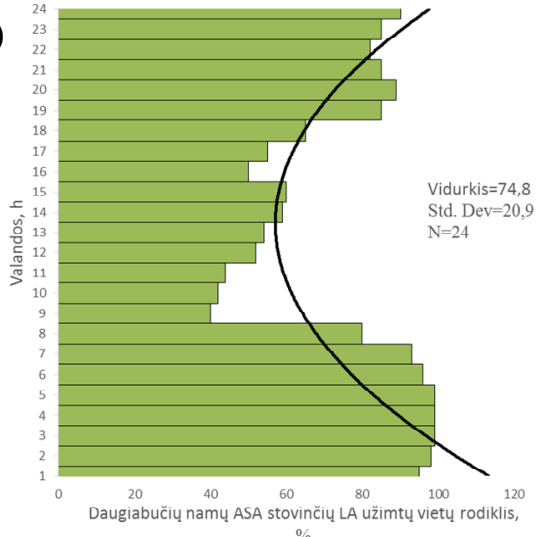

2.5 pav. Prekybos centrų (a) ir daugiabučių namų (b) automobilių stovejjimo aikštelių apkrovimo automobiliais pasiskirstymas paros metu (sudaryta autoriaus)

Fig. 2.5. Distribution of the loading of car parking's of shopping centres and multi-storey houses with cars during twenty four hours (author's)

Iš 2.5 paveikslo matyti, kad 24 valandų laikotarpyje PC ASA užpildymo rodiklis siekia nuo $23 \%$ iki $89 \%$. Didžiausias užpildymo rodiklis nustatytas 18 val. vakare, mažiausias -6 val. ryte. Apskaičiuotas standartinis nuokrypis (vidutinis kvadratinis nuokrypis) - 23,8. 
Daugiabučiu namų ASA užpildymo rodiklis siekia nuo $40 \%$ iki $100 \%$. Didžiausias užpildymo rodiklis nustatytas nuo 24 val. iki 6 val. ryto, mažiausias - 9 val. ryte. Apskaičiuotas standartinis nuokrypis - 20,9.

\subsubsection{Prekybos centrų automobilių stovèjimo aikštelių parametrų svarbos tyrimas AHP metodu}

Atlikus natūrinio tyrimo analizę nèra aišku, nuo kokių veiksnių priklauso PC ASA užpildymo rodiklis kai nedirba prekybos centrai. Todèl, siekiant išsiaiškinti, kokie veiksniai turi įtakos užpildymui, buvo sudarytas kriterijų sąrašas, kuris apibrežia PC ASA užpildymo rodiklio dydi Šis sąrašas skirtas teritorijai 300 metrų spinduliu nuo PC ASA (2.6 pav.).

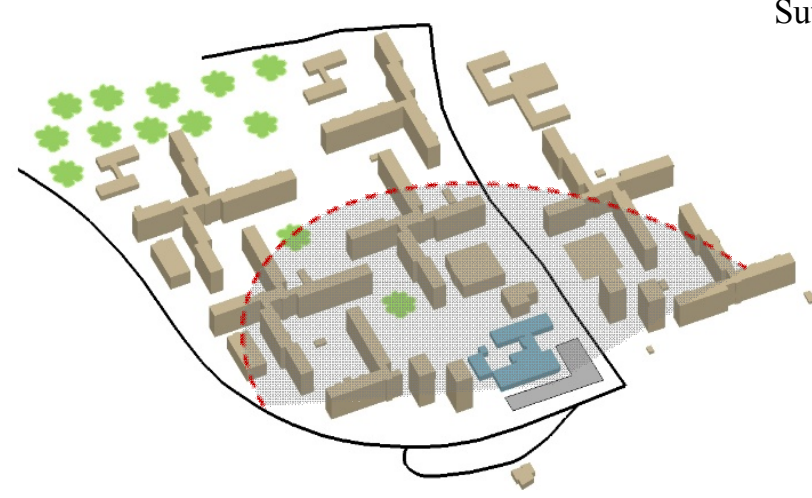

2.6 pav. Prekybos centro tyrimų schema (sudaryta autoriaus)

Fig. 2.6. Research scheme of shopping center (author's)

Ekspertizès būdu buvo nustatyti ir atrinkti 7 kriterijai (2.7 lentelè):

1. Užstatymo intensyvumas (toliau $-\mathrm{B}_{1}$ ) - visų pastatų antžeminès dalies patalpų bendrojo ploto sumos santykis su žemès sklypo plotu, išreikštas procento dalimi.

2. Gatvių prie PC važiuojamosios juostos plotis (toliau $-\mathrm{B}_{2}$ ). Prie PC ASA, kurias skyrė B, C, D ir mažesnès kategorijos gatvès, buvo išmatuotas važiuojamosios dalies plotis.

3. Butu skaičius (toliau - $\mathrm{B}_{3}$ ) ir dirbančiųju gyventojų skaičius (toliau $\mathrm{B}_{6}$ ) buvo nustatytas remiantis Lietuvos statistikos departamento pateikta informacija.

4. Butų vertė (toliau $-\mathrm{B}_{4}$ ) apskaičiuota pagal Uždarosios akcinès bendrovès (toliau - UAB) „CodeIn“ pateiktus duomenis. 
5. PC ASA tiesioginis matomumas iš aplinkinių butų (toliau - $\mathrm{B}_{5}$ ) apskaičiuotas GIS priemonėmis.

6. ASV poreikis (toliau $-\mathrm{B}_{7}$ ) apskaičiuotas pagal minimalius ASV ịrengimo reikalavimus prie daugiabučių namų; remtasi dokumentu STR 2.06.01:1999 „Miestų, miestelių ir kaimų susisiekimo sistemos“.

2.7 lentelè. Kriterijai, nuo kurių priklauso prekybos centrų automobilių stovėjimo aikštelių užpildymas

Table 2.7. Criteria conditioning filling of car parking's of shopping centers

\begin{tabular}{clc}
\hline $\begin{array}{c}\text { Kriterijaus } \\
\text { Nr. }\end{array}$ & \multicolumn{1}{c}{ Kriterijai } & $\begin{array}{c}\text { Matavimo } \\
\text { vienetai }\end{array}$ \\
\hline $\mathrm{B}_{1}$ & Užstatymo intensyvumas & $\%$ \\
\hline $\mathrm{B}_{2}$ & Gatvių prie PC važiuojamosios juostos plotis & metrai \\
\hline $\mathrm{B}_{3}$ & Butų skaičius & vnt. \\
\hline $\mathrm{B}_{4}$ & Butų vertė & $\mathrm{Lt} / \mathrm{m}^{2}$ \\
\hline $\mathrm{B}_{5}$ & $\begin{array}{l}\text { PC ASA tiesioginis matomumo atstumas iš aplinkinių } \\
\text { butų }\end{array}$ & $\%$ \\
\hline $\mathrm{B}_{6}$ & Dirbantieji gyventojai & $\mathrm{vnt}$. \\
\hline $\mathrm{B}_{7}$ & $\begin{array}{l}\text { ASV poreikio koeficientas (reikiamų vietų skaičiaus } \\
\text { santykis su turimų vietų skaičiumi) }\end{array}$ & $\%$ \\
\hline
\end{tabular}

Siekiant nustatyti pagrindinius kriterijus, nuo kuriu priklauso PC ASA užpildymo koeficientas, sudaryta ekspertinè apklausos anketa, kurią pildè 8 ekspertai.

2.8 lentelè. Kriterijų rangai

Table 2.8. Rates of criteria

\begin{tabular}{ccccccccccc}
\hline $\begin{array}{c}\text { Kriterijai } \\
(m)\end{array}$ & \multicolumn{1}{c}{ Ekspertai } & $\begin{array}{c}\text { Rangu } \\
\text { suma }\end{array}$ & Vieta \\
\cline { 2 - 10 } & $\mathrm{r}_{1}$ & $\mathrm{r}_{2}$ & $\mathrm{r}_{3}$ & $\mathrm{r}_{4}$ & $\mathrm{r}_{5}$ & $\mathrm{r}_{6}$ & $\mathrm{r}_{7}$ & $\mathrm{r}_{8}$ & \\
\hline $\mathrm{B}_{1}$ & 2 & 2 & 6 & 4 & 4 & 3 & 3 & 6 & 30 & $3-4$ \\
\hline $\mathrm{B}_{2}$ & 5 & 6 & 7 & 5 & 6 & 6 & 7 & 4 & 46 & 6 \\
\hline $\mathrm{B}_{3}$ & 3 & 4 & 3 & 7 & 2 & 4 & 2 & 5 & 30 & $3-4$ \\
\hline $\mathrm{B}_{4}$ & 7 & 7 & 5 & 6 & 7 & 7 & 6 & 3 & 48 & 7 \\
\hline $\mathrm{B}_{5}$ & 6 & 3 & 4 & 3 & 5 & 2 & 5 & 7 & 35 & 5 \\
\hline $\mathrm{B}_{6}$ & 4 & 5 & 2 & 2 & 3 & 5 & 4 & 2 & 27 & 2 \\
\hline $\mathrm{B}_{7}$ & 1 & 1 & 1 & 1 & 1 & 1 & 1 & 1 & 8 & 1 \\
\hline
\end{tabular}

Ekspertai rangavo kriterijus, išdèstydami juos eilès tvarka, vertinimo tikslo svarbumo atžvilgiu. Svarbiausiam kriterijui buvo priskirta aukščiausia reikšmè, 
lygi vienetui, kitam kriterijui (pagal ịtaką nagrinejjamam tikslui) - reikšmè 2 ir taip toliau, mažiausiai svarbiam kriterijui - reikšmė $m$, kur $m$ - vertinamų kriterijų skaičius. Rangavimas leidžia ekspertams išskirti svarbiausius ir nereikšmingus kriterijus, įvertina jų reikšmingumą. Matematinès statistikos metodais nustatomas ekspertų nuomonių suderinamumas. Anketos duomenų tvarkymo skaitinis pavyzdys pateiktas 2.8 lentelëje.

Remiantis 2.8 lenteleje pateiktais duomenimis, pagal (2.1)-(2.8) formules skaičiuojamas konkordancijos koeficientas $-W=0,597$. Toliau pagal (2.7) formulę skaičiuojamas $\chi^{2}=28,66$. Atlikus skaičiavimus nustatyta, kad $\chi^{2}$ kurios reikšmė viršija kritinę $\chi_{k r}^{2}=12,59$ su laisvès laipsniu $\alpha=0,05$ ir $v=7-1=6$ reikšmingumo lygmeniu, ekspertų nuomonès suderintos.

2.9 lentelè. Ekspertų tiesioginis kriterijų reikšmingumo vertinimas ir kriterijų svoriai Table 2.9. The direct estimates of criteria significance made by experts and criteria weights

\begin{tabular}{cccccccccccc}
\hline & \multicolumn{1}{c}{ Ekspertai } & \multicolumn{1}{c}{ Vertinimu } & Svoriai & Vieta \\
\cline { 2 - 11 } & $\mathrm{r}_{1}$ & $\mathrm{r}_{2}$ & $\mathrm{r}_{3}$ & $\mathrm{r}_{4}$ & $\mathrm{r}_{5}$ & $\mathrm{r}_{6}$ & $\mathrm{r}_{7}$ & $\mathrm{r}_{8}$ & & & \\
\hline $\mathrm{B}_{1}$ & 21 & 24 & 10 & 15 & 5 & 15 & 15 & 5 & 110 & 0,1375 & 4 \\
\hline $\mathrm{B}_{2}$ & 11 & 5 & 6 & 13 & 1 & 8 & 5 & 10 & 59 & 0,0738 & $6-7$ \\
\hline $\mathrm{B}_{3}$ & 18 & 15 & 20 & 10 & 20 & 12 & 20 & 10 & 125 & 0,1562 & 2 \\
\hline $\mathrm{B}_{4}$ & 4 & 4 & 12 & 12 & 2 & 5 & 5 & 15 & 59 & 0,0738 & $6-7$ \\
\hline $\mathrm{B}_{5}$ & 7 & 16 & 12 & 15 & 2 & 20 & 10 & 5 & 87 & 0,1088 & 5 \\
\hline $\mathrm{B}_{6}$ & 14 & 10 & 20 & 15 & 20 & 10 & 15 & 20 & 124 & 0,1550 & 3 \\
\hline $\mathrm{B}_{7}$ & 25 & 26 & 20 & 20 & 50 & 30 & 30 & 35 & 236 & 0,2950 & 1 \\
\hline
\end{tabular}

Papildomai visi aštuoni ekspertai tiesiogiai (\%) ịvertino kiekvieno kriterijaus reikšmingumą $c_{i k}\left(\sum_{i=1}^{m}=c_{i k}=100 ; k=1,2 \ldots, r\right)$. Vertinimai duoda galimybę suskaičiuoti jų svorius $\omega_{i}$ kaip visų vertinimų vidurkius pagal formulę:

$$
\omega_{i}=\sum_{k=1}^{r} c_{i k} /(100 r)(i=1,2, \ldots, m) .
$$

Ekspertų kriterijų reikšmingumo vertinimai ir jų svoriai pateikti 2.9 lentelëje.

Kadangi visi aštuoni ekspertai vieningai anketinèje apklausoje nurodè, kad didžiausias PC ASA užpildymo koeficientas priklauso nuo ASV poreikio, svorių sumažinimui buvo taikomi papildomi metodai: AHP (2) ir tiesioginis kriterijų 
reikšmingumo vertinimo metodas. Šiais metodais iš naujo atliktas reikšmingumo vertinimas ir apskaičiuoti kriterijų svoriai, kurie sumažino ASV poreikio svorị (2.7 pav.).

2.10 lentelè. Skirtingais metodais suskaičiuoti prekybos centrų automobilių stovejjimo aikštelių kriterijų svoriai

Table 2.10. Criteria weights calculated of car parking's of shopping centers using different methods

\begin{tabular}{cccccccc}
\hline \multirow{2}{*}{ Metodai } & \multicolumn{7}{c}{ Kriterijai } \\
\cline { 2 - 8 } & $\mathrm{B}_{1}$ & $\mathrm{~B}_{2}$ & $\mathrm{~B}_{3}$ & $\mathrm{~B}_{4}$ & $\mathrm{~B}_{5}$ & $\mathrm{~B}_{6}$ & $\mathrm{~B}_{7}$ \\
\hline AHP (1) & 0,1020 & 0,0402 & 0,2414 & 0,0395 & 0,0674 & 0,1543 & 0,3553 \\
\hline AHP (2) & 0,0944 & 0,0440 & 0,2200 & 0,0457 & 0,0512 & 0,1594 & 0,3853 \\
\hline Tiesioginis & 0,1375 & 0,0738 & 0,1563 & 0,0738 & 0,1088 & 0,1550 & 0,2950 \\
\hline Svorių vidurkiai & 0,1113 & 0,0527 & 0,2058 & 0,0531 & 0,0759 & 0,1562 & 0,3452 \\
\hline Vieta & 4 & 7 & 2 & 6 & 5 & 3 & 1 \\
\hline
\end{tabular}

Ekspertu porinio palyginimo suderinamumo indeksas C.I. $=0,036$, suderinamumo santykis C.R. $=0,027<0,1$, tai reiškia, kad vertinimai yra suderinti. Papildomai, atsitiktinumo poveikio svorių nustatymo sumažinimui, tie patys ekspertai dar karta užpildè AHP metodo kriterijų palyginimo matricą.

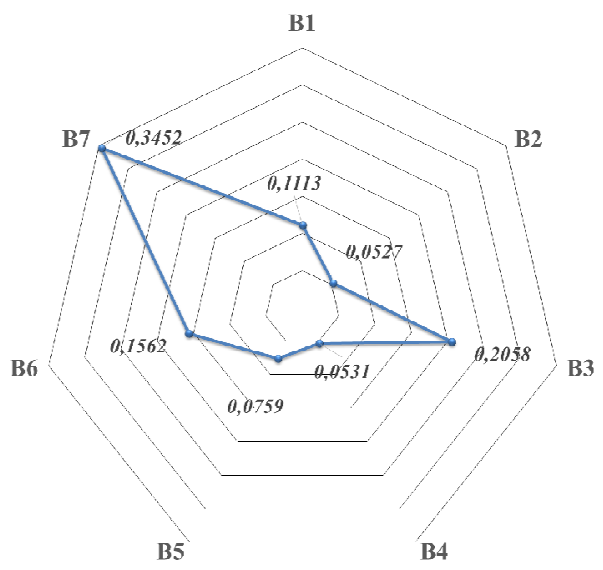

2.7 pav. Prekybos centrų automobilių stovèjimo aikštelių kriterijų reikšmingumo vidurkiai (sudaryta autoriaus)

Fig. 2.7. The averages of criteria significance of car parking's of shopping centres (author's) 
Dviejų AHP metodo vertinimo ir tiesioginio vertinimo svoriai ir jų vidurkiai pateikti 2.10 lentelèje.

Atlikus skaičiavimus, buvo pritaikytas vidurkio svorių metodas. PC ASA užpildymo koeficientui didžiausią reikšmę turi ASV poreikis $(0,3452)$, butų skaičius (0,2058), dirbančiujų gyventojų skaičius gyvenamajame rajone $(0,1562)$. Mažiausią reikšmę, ekspertų nuomone, aikštelès užpildymo koeficientui turi gatvių prie PC važiuojamosios juostos plotis $(0,0527)$ ir butų vertè $(0,0531)$.

\subsubsection{Statyk ir važiuok aikšteliụ plètros strategija Vilniaus mieste}

Intensyvejantis darbo ir gyvenimo ritmas didžiuosiuose miestuose sunkiai išsivaizduojamas be transporto. Viena iš aktualiausių problemų, su kuria susiduria didžiujų miestų gyventojai, yra susijusi su ASV trūkumu mieste (Grigonis and Paliulis 2009).

Per pastaruosius 50 metų Vilniaus miesto SS pasikeitè iš esmès. Apie $1960 \mathrm{~m}$. Vilniuje VT sistema buvo praktiškai vienintelis susisiekiamo būdas (>95\%), maždaug po 30 metų jau dominavo LA, dar po 10 metu VT reikšmè sumažèjo 20-30\%. Nuo $1981 \mathrm{~m}$. iki $2014 \mathrm{~m}$. LA skaičius Vilniuje išaugo daugiau kaip 5 kartus. Automobilizacijos lygio augimo priežastis - LA protegavimo politika. Tokios vystymo politikos pasekmès - gyvenimo būdo pokyčiai, nepasotinamas infrastruktūros poreikis, grūstys gatvėse, ASV trūkumas ir kita.

ASV trūkumo poreikị Vilniaus mieste bandyta išspręsti statant daugiaaukštes, antžemines ir požemines ASA. Didejjančiam LA srautui buvo platinamos gatvès, kuriamas didelio eismo pralaidumo miestų gatvių tinklas ir kita. Šie sprendimai neleido sumažinti LA skaičiaus mieste, jie tik privedè prie sunkesnių pasekmių. Vilniuje dominuojančios originalios viešojo keleivių SS (troleibusai ir autobusai) palaipsniui prarado prioritetą. Pasikeitę žmonių gyvenimo būdo pokyčiai, siekiant atlikti kelionę „,nuo durų iki durų“, mažèjantis VT greitis, pasiekiamumas, komfortas ir kiti požymiai paskatino integruoti SS i urbanistinès plètros planavimo procesus (Burinskienè et al. 2011; Hickman et al. 2013).

Vilniaus mieste planuojama diegti SV sistemą, kuri yra originali viešoji keleivių SS, veikianti kaip tradicinio VT papildinys. Ši sistema plačiai populiarèja Europos miestuose. Jos esmę sudaro tai, kad LA paliekamas specialioje ASA miesto prieigose ir tolesnè kelionè tęsiama VT arba specialiu SV sistemos autobusu. Ši sistema orientuota i miesto centro apkrovos LA mažinimą, ji padeda sumažinti TP keliamą triukšmą, oro ir vizualinę taršą mieste, taupo keleivių laiką ir pinigus. Atsižvelgiant ị ES struktūrinès paramos 
periodu numatytą finansavimą, skirtą SV sistemos plètrai penkiuose didžiausiuose Lietuvos miestuose (Vilniuje, Kaune, Klaipedoje, Šiauliuose ir Panevėžyje), Vilniaus mieste analizuojamos šios sistemos plètros galimybès.

Pagal Baltosios knygos rekomendacijas Vilniuje perspektyvoje prioritetas teikiamas VT, pèsčiųjų ir dviratininkų eismui miesto centrinejje dalyje ir gyvenamuosiuose rajonuose. Siekiama kelti VT prestižą, Vilniuje ịvesti naują SS - SV sistemą. Jos plètra ir kiti sisteminiai dalykai gali sumažinti bendrą miesto transporto keliamą taršą iki $60 \%$.

$2012 \mathrm{~m}$. Vilniaus miesto tarybos sprendimu buvo patvirtinti „Naujų transporto rūšių diegimo Vilniaus mieste“ SP sprendiniai. Šiame dokumente Vilniaus miesto SS plètrą numatoma igyvendinti kompleksiškai, apjungiant VT su SV sistema bei kitomis miesto SS rūšimis.

Vilniaus miesto BP sprendiniuose yra nurodytos 33 preliminarios SV sistemos ASA įrengimo vietos.

\subsubsection{Statyk ir važiuok sistemos automobiliụ stovèjimo aikštelių rodiklių svarbos tyrimas AHP metodu}

İdiegti SV sistemą ir teisingai parinkti ASA vietas Vilniaus miesto teritorijoje yra labai sudètinga, nes SV sistemos plètra reikalauja ịvertinti ekonominius, socialinius, urbanistinius ir kitus veiksnius. Todèl, siekiant nustatyti, kokie veiksniai turi įtakos SV sistemos ASA vietų parinkimui, buvo sudarytas 11 kriterijų sąrašas (2.11 lentelè):

1. SV sistemos ASA žemès kaina ir jos įrengimo kaina (toliau $-\mathrm{C}_{1}$ ). Šis kriterijus yra vienas svarbiausių parenkant aikštelès vietą. Jeigu žemès kaina bus prieinama savivaldybei ir investuotojams, tikètina, kad toje vietoje bus įrengta ASA. Žemès kaina buvo nustatyta pagal Valstybès įmonès „Registrų centras“" pateiktą žemès verčių žemėlapį. ASA ịrengimo kaina paskaičiuota pagal UAB „Sistela“ pateiktus statinių statybos skaičiuojamujų kainų palyginamuosius ekonominius rodiklius.

2. Eismo intensyvumas gatvejje šalia planuojamos SV sistemos ASA (toliau $-\mathrm{C}_{2}$ ). Atlikta užsienio šalių patirties analizė rodo, kad kuo didesnis eismo intensyvumas šalia aikštelès, tuo didesnè tikimybè, kad LA vairuotojas pasinaudos SV sistemos ASA. Šio kriterijaus skaitinè reikšmė nustatyta remiantis „Naujų transporto rūšių diegimo Vilniaus mieste“ SP esamoje būklèje atliktais tyrimais.

3. VT maršrutų skaičius piko valandą (toliau $-\mathrm{C}_{3}$ ). VT maršrutinis tankis parodo VT aptarnavimo lygi mieste, nes kuo didesnis maršrutų tankis, tuo daugiau galimybių keleiviui pasiekti kelionès tikslą greičiau (UšpalytėVitkūnienè et al. 2012). Šio kriterijaus skaitinè reikšmė nustatyta pagal VT 
maršruto tvarkaraščiuose pateiktus duomenis, kurie paskelbti SI „Susisiekimo paslaugos“ internetinèje svetainèje.

4. Važiavimo trukmé VT (toliau $-\mathrm{C}_{4}$ ). Mažas važiavimo greitis - tai pagrindinè priežastis, verčianti LA vairuotojus rinktis ne VT, o LA. Šis kriterijus nustatytas pagal VT maršrutų atvykimo laiką nuo planuojamos ASA iki miesto centro ribos. Atstumas išmatuotas GIS priemonėmis.

5. Iš LA vagysčių tikimybe SV sistemos ASA (toliau - $\mathrm{C}_{5}$ ). $2013 \mathrm{~m}$. duomenimis Lietuvoje KASKO draudimu buvo apdrausta 117,2 tūkst. TP, tai rodo, kad vairuotojams LA yra svarbus turtas, kuri reikia saugoti. Saugumo kriterijus buvo vertinamas trijų balų sistema: 3 balai - saugi ASA, 2 - vidutiniškai saugi, 1 - nesaugi.

6. Vairuotoju informavimo apie laisvas vietas informacinè sistema (toliau $-\mathrm{C}_{6}$ ). Informaciniu sistemu taikymas sudaro prielaidas optimizuoti LA laidumą ir sutrumpinti kelionès laiką ieškant laisvos ASV. Šio kriterijaus skaitinė reikšmė išreiškiama dviejų balų sistemoje: 2 - yra informacinè sistema ir 1 - jos nèra.

7. AS kaina SV sistemos ASA. (toliau $-\mathrm{C}_{7}$ ). Kaina yra labai dažnai aktuali LA vairuotojams. Jeigu yra galimybè pasistatyti LA nemokamai arba mokamai, tai vairuotojas dažniausiai renkasi nemokamą arba pigiausią stovejjimo vietą. AS kaina SV sistemos ASA skaičiuojama litais.

8. LA ịvažiavimas ị SV aikštelę (toliau $-\mathrm{C}_{8}$ ). LA vairuotojams turi būti užtikrintas greitas ir patogus ịvažiavimas į ASA, kai jis tvarko įvažiavimo ir išvažiavimo dokumentus kiek galima mažiau sugaištant laiko. Šio kriterijaus skaitinè reikšmė išreiškiama dviejų balų sistemoje: 2 - saugus ivvažiavimas ir 1 - nesaugus.

9. Gatvių kategorija (toliau $-\mathrm{C}_{9}$ ). Nuo pagrindinių techninių gatvès rodiklių (važiuojamosios juostos pločio, projektinio greičio, eismo juostų skaičiaus ir kitų rodiklių) priklauso SV sistemos ASA veikla. Gatvių kategorijos skaitinè reikšmė išreikšta važiuojamosios dalies pločiu.

10. Integruota LA stovejjimo ir važiavimo VT bilieto kaina (toliau $-\mathrm{C}_{10}$ ). LA vairuotojas su integruotu bilietu jo galiojimo metu gali persėsti iš vienos TP ì kitą neribotą skaičių kartų ir nemokamai. Todèl integruota LA ir važiavimo VT bilieto kaina taupys keleivių laiką ir pinigus. Bilieto kaina išreiškiama litais.

11. Vilniaus miesto BP numatytas užstatymo intensyvumas (toliau $-\mathrm{C}_{11}$ ). Užstatymo intensyvumas - tai teritorijos panaudojimo efektyvumą nusakantis užstatymo rodiklis, nuo kurio priklauso toje teritorijoje esamų ar prognozuojamų stovinčių LA skaičius. Ši kriterijais skaitinè reikšmé išreikšta procentais. 
2.11 lentelè. Kriterijai, nuo kurių priklauso statyk ir važiuok sistemos automobilių stovèjimo aikštelių parinkimo vieta

Table 2.11. Criteria conditioning selection of the area of park and ride system's car parking's

\begin{tabular}{|c|c|c|}
\hline $\begin{array}{l}\text { Kriterijaus } \\
\text { Nr. }\end{array}$ & Kriterijaus pavadinimas & $\begin{array}{l}\text { Matavimo } \\
\text { vienetai }\end{array}$ \\
\hline $\mathrm{C}_{1}$ & $\begin{array}{l}\text { SV sistemos ASA žemės kaina ir jos ịrengimo } \\
\text { kaina }\end{array}$ & tūkst. Lt \\
\hline $\mathrm{C}_{2}$ & $\begin{array}{l}\text { Eismo intensyvumas gatvèje šalia planuojamos } \\
\text { SV sistemos ASA }\end{array}$ & aut./parą \\
\hline $\mathrm{C}_{3}$ & VT maršrutų skaičius piko valandą & $\begin{array}{l}\text { maršrutų sk./piko } \\
\text { valandą }\end{array}$ \\
\hline $\mathrm{C}_{4}$ & Važiavimo trukmè VT & $\mathrm{km} / \mathrm{h}$ \\
\hline $\mathrm{C}_{5}$ & Vagysčių tikimybė ASA & balai \\
\hline $\mathrm{C}_{6}$ & $\begin{array}{l}\text { Vairuotojų informavimo apie laisvas vietas } \\
\text { informacinè sistema }\end{array}$ & balai \\
\hline $\mathrm{C}_{7}$ & AS kaina SV sistemos ASA & $\mathrm{Lt}$ \\
\hline $\mathrm{C}_{8}$ & LA ịvažiavimas ị SV aikštelę & balai \\
\hline $\mathrm{C}_{9}$ & Gatvių kategorija & metrai \\
\hline $\mathrm{C}_{10}$ & $\begin{array}{l}\text { Integruota LA stovejjimo ir važiavimo VT } \\
\text { bilieto kaina }\end{array}$ & $\mathrm{Lt}$ \\
\hline $\mathrm{C}_{11}$ & $\begin{array}{l}\text { Vilniaus miesto BP numatytas užstatymo } \\
\text { intensyvumas }\end{array}$ & $\%$ \\
\hline
\end{tabular}

SV sistemos ASA plètra išreiškiama kiekybinių ir kokybinių kriterijų sąrašu (2.11 lentelè). Suformulavus šiuos 11 kriterijų, buvo sudarytas SV sistemos ASA teorinis modelis (2.8 pav.).

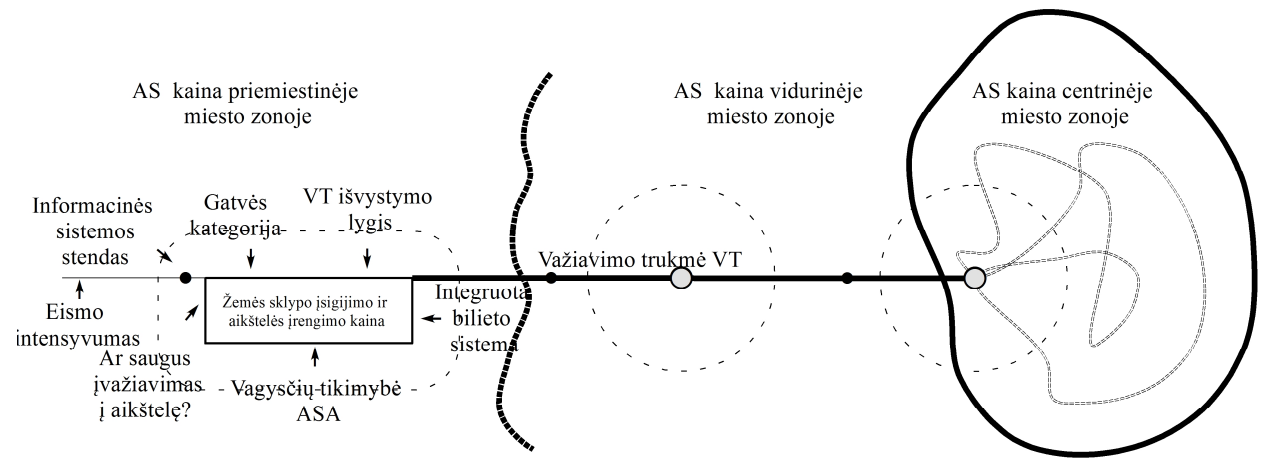

2.8 pav. Statyk ir važiuok sistemos teorinis modelis (sudaryta autoriaus)

Fig. 2.8. Theoretical model of the park and ride system (author's) 
Visiems kriterijams suteiktos skaitinès reikšmès ir toliau AHP ir rangu koreliacijos metodu nustatomi kriterijų svoriai.

2.12 lentelė. Kriterijų rangavimo rezultatai

Table 2.12 The results of criteria ranking

\begin{tabular}{|c|c|c|c|c|c|c|c|c|c|c|c|}
\hline \multirow{2}{*}{$\begin{array}{l}\text { Kriterijaus } \\
\text { Nr. }\end{array}$} & \multirow{2}{*}{$\begin{array}{l}\text { Kriterijaus } \\
\text { pav. }\end{array}$} & \multicolumn{8}{|c|}{ Ekspertų suteikti kriterijams rangai } & \multirow{2}{*}{ Svoriai } & \multirow{2}{*}{ Vieta } \\
\hline & & 1 & 2 & 3 & 4 & 5 & 6 & 7 & 8 & & \\
\hline $\mathrm{C}_{1}$ & $\begin{array}{l}\text { ASA } \\
\text { ịrengimo } \\
\text { kaina }\end{array}$ & 2 & 2 & 5 & 7 & 7 & 8 & 8 & 8 & 0,089 & 6 \\
\hline $\mathrm{C}_{2}$ & $\begin{array}{l}\text { Eismo } \\
\text { intensyvum } \\
\text { as }\end{array}$ & 5 & 3 & 3 & 5 & 8 & 9 & 9 & 10 & 0,098 & 4 \\
\hline $\mathrm{C}_{3}$ & $\begin{array}{l}\text { VT tinklo } \\
\text { išvystymas }\end{array}$ & 11 & 8 & 11 & 10 & 10 & 11 & 11 & 11 & 0,157 & 1 \\
\hline $\mathrm{C}_{4}$ & $\begin{array}{l}\text { Važiavimo } \\
\text { trukmé VT }\end{array}$ & 10 & 11 & 8 & 11 & 11 & 10 & 10 & 7 & 0.148 & 2 \\
\hline $\mathrm{C}_{5}$ & $\begin{array}{l}\text { Vagysčiu } \\
\text { tikimybė } \\
\text { ASA }\end{array}$ & 8 & 10 & 6 & 3 & 4 & 1 & 4 & 2 & 0,072 & 7 \\
\hline $\mathrm{C}_{6}$ & $\begin{array}{l}\text { Vairuotojų } \\
\text { informavim } \\
\text { o sistema }\end{array}$ & 6 & 5 & 7 & 2 & 6 & 2 & 3 & 5 & 0,068 & 8 \\
\hline $\mathrm{C}_{7}$ & $\begin{array}{l}\text { AS kaina } \\
\text { aikštelëje }\end{array}$ & 9 & 9 & 4 & 9 & 9 & 7 & 5 & 6 & 0,110 & 3 \\
\hline $\mathrm{C}_{8}$ & $\begin{array}{l}\text { Ar patogus } \\
\text { ịvažiavimas } \\
\text { i aikštelę? }\end{array}$ & 1 & 6 & 10 & 1 & 5 & 6 & 2 & 3 & 0,064 & 9 \\
\hline $\mathrm{C}_{9}$ & $\begin{array}{l}\text { Gatvès } \\
\text { kategorija }\end{array}$ & 3 & 4 & 1 & 6 & 3 & 5 & 1 & 1 & 0,045 & 11 \\
\hline $\mathrm{C}_{10}$ & $\begin{array}{l}\text { Integruota } \\
\text { LA ir } \\
\text { važiavimo } \\
\text { VT bilieto } \\
\text { kaina }\end{array}$ & 7 & 7 & 9 & 8 & 1 & 3 & 6 & 9 & 0,095 & 5 \\
\hline $\mathrm{C}_{11}$ & $\begin{array}{l}\text { Užstatymo } \\
\text { intensyvum } \\
\text { as }\end{array}$ & 4 & 1 & 2 & 4 & 2 & 4 & 7 & 4 & 0,053 & 10 \\
\hline
\end{tabular}

Kriterijų svoriai buvo nustatyti taikant jų rangavimą. Svoriai skaičiuojami pagal (2.1)-(2.8) formules. Pagal (2.6) formulę suskaičiuotas konkordancijos koeficientas $-W=0,520$, pagal (2.7) formulę reikšmè $-\chi^{2}=41,61$, kuri 
viršija kritinę $\chi_{k r}^{2}=18,31$ su reikšmingumo lygmeniu $\alpha=0,05$ ir $v=11-1=10$ laisvès laipsniu. Tai rodo, kad ekspertų nuomonès suderintos.

2.9 paveiksle pateikiami SV sistemos ASA vietos parinkimo kriteriju svoriai.

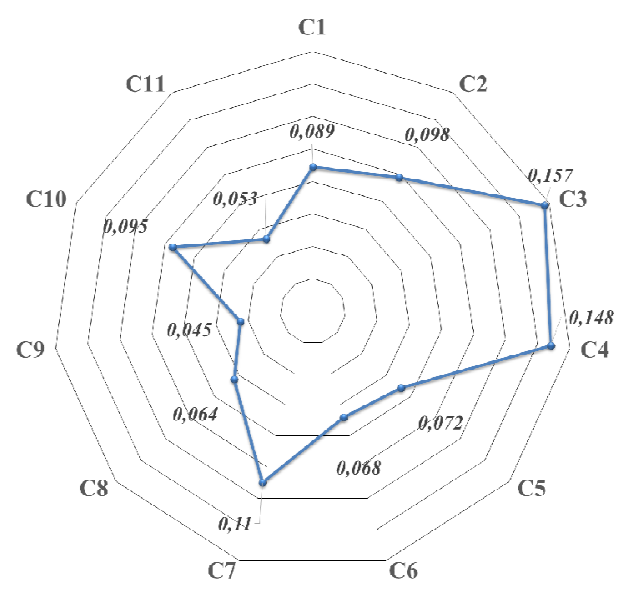

2.9 pav. Statyk ir važiuok sistemos automobilių stovèjimo aikštelių vietos parinkimo kriterijų svoriai (sudaryta autoriaus)

Fig. 2.9. Weights of the criteria of park and ride system's car parking's area selection (author's)

SV sistemos ASA vietos parinkimas labiausiai priklauso nuo VT tinklo išvystymo $(0,157)$, miesto centro pasiekiamumo VT $(0,148)$, AS kainos SV aikštelèje $(0,110)$. Mažiausią reikšmę, ekspertų nuomone, vietos parinkimui turi užstatymo intensyvumas $(0,053)$ ir gatvès kategorija $(0,045)$.

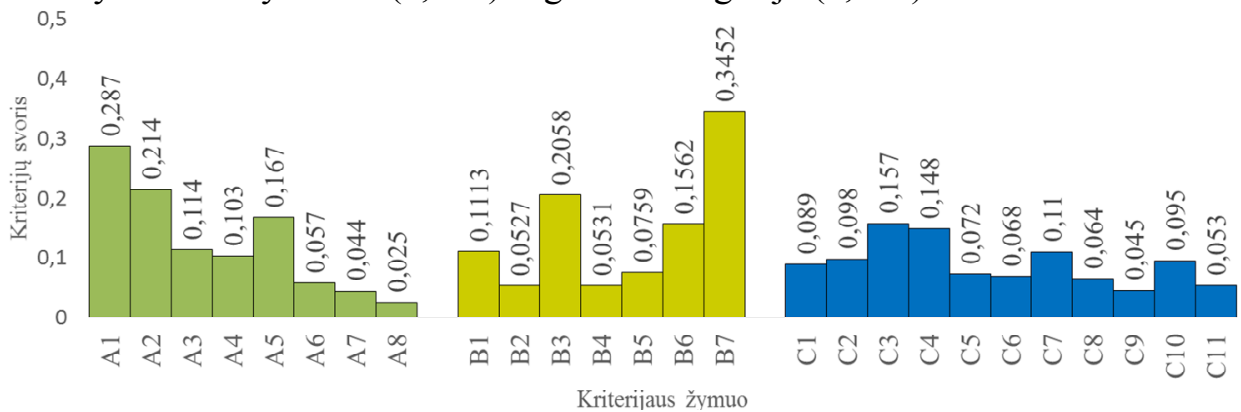

2.10 pav. Statyk ir važiuok sistemos automobilių stovèjimo aikštelių vietos parinkimo kriterijų svoriai (sudaryta autoriaus)

Fig. 2.10. Weights of the criteria of park and ride system's car parking's area selection (author's) 
2.10 paveiksle pateikti suskaičiuoti trijų grupių (A, B ir C) 26 kriterijų svoriai. Iš stulpelinès diagramos matyti, kad didžiausia svorio vertè yra $\mathrm{B}_{7}$ grupès kriterijaus (ASV poreikio koeficientas).

\subsubsection{Statyk ir važiuok sistemos plètros koncepcijos}

SV sistemos funkcionavimo sėkmé priklauso nuo SS integracijos ị miestų planavimo procesą, kurio metu yra išsprendžiami žemės nuosavybės klausimai, nustatomos finansinių išteklių ir susisiekimo poreikis.

Siekiant įvertinti SV sistemos įrengimo Vilniaus mieste galimybes, autorius parenge tris galimas SV sistemos koncepcijas (2.11 pav. a, b ir c).

a)

Rajonas + priemiestinè zona

Vidurinè miesto zona

Centrinè miesto zona

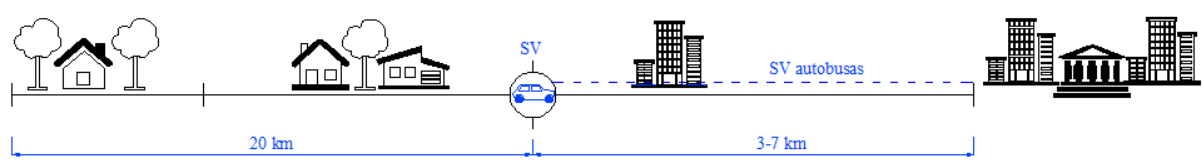

b)

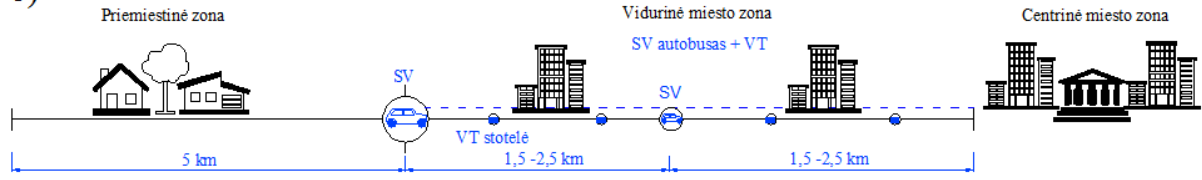

c)

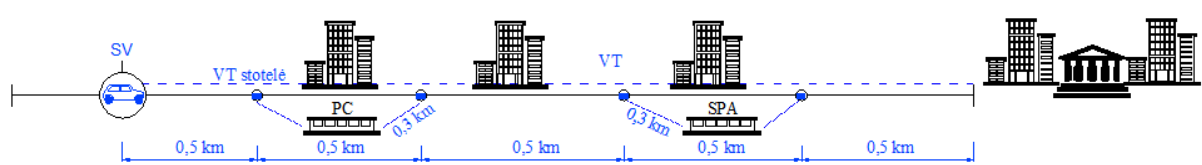

2.11 pav. Statyk ir važiuok sistemos koncepcijos modeliai:

a) pirmoji koncepcija; b) antroji koncepcija; c) trečioji koncepcija

(sudaryta autoriaus)

Fig. 2.11. Models of park and ride system's conception:

a) first conception; b) second conception; c) third conception (author's)

Pirmajai koncepcijai priskiriamos daugiausiai nutolusios nuo miesto centro SV sistemos ASA. Jos skirtos rajone ir priemiestinèse teritorijose gyvenantiems žmonėms, kurie skatinami palikti LA stovejjimo aikštelèje ir toliau kelionę tęsti specialiu SV sistemos autobusu ị miesto centrą (2.11 pav. a). İvertinus užsienio miestų patirtị, planuojant ASA vietų skaičius aikštelèje turètų būti nemažesnis kaip 200. Atstumas nuo SV sistemos ASA iki miesto centro turi būti 3-7 km. 
Pavyzdžiui, jeigu SV sistemos aikštelè būtų ịrengta Santariškèse, tai SV sistemos autobusas centrą pasiektų per 14 min.

Antrajai koncepcijai priskiriamos priemiestinejje ir vidurinejje miesto zonoje esančios ASA. Šios koncepcijos tikslas - nukreipti keleivių srautus iš priemiestinès ir vidurinès miesto zonų i miesto centrą (2.11 pav. b). Šioje koncepcijoje SV sistemos ASA gali aptarnauti VT ir specialus SV sistemos autobusas. Skirtumas tas, kad VT stoja visose VT stotelèse, o SV sistemos autobusas stoja tik SV sistemos aikštelèse. Šios koncepcijos privalumas keleivis turi galimybę pasirinkti keliauti ne tik ị centrą, bet ir ị kitas miesto teritorijas. Planuojant ASA SV sistemos autobuso maršrute, aikštelių vietų skaičius priklauso nuo ASV poreikio ir miesto zonos. Pavyzdžiui, pradinèje SV sistemos ASA vietų skaičius turi būti ne nemažesnis kaip 200, kitose miesto zonose ASA vietų skaičius turi būti nustatytas pagal ASV poreikị.

Trečiajai koncepcijai priskiriamos SV sistemos ASA, kurios ịrengiamos šalia pagrindinių VT koridorių. Šios aikštelès yra arčiausiai miesto centro, todėl jos dažniausiai įrengiamos panaudojant esamų ASA infrastruktūrą: PC, sporto ir pramogu kompleksų aikšteles (toliau - SPA) arba ịrengiant naujas nedideles ASA (2.11 pav. c). Planuojant PC įrengti SV sistemos ASA, nuo pastarosios iki VT stotelès turètų būti išlaikomas ne didesnis kaip 300 metrų atstumas. Tuo tarpu tarp VT stotelių turètų būti išlaikomas ne didesnis kaip 500 metrų atstumas. İrengiant SV sistemos ASV PC ar SPA, turi būti išspręsti teisiniai, organizaciniai ir ekonominiai klausimai. Gavus iš savininkų leidimą ịrengti SV sistemai skirtą ASV turi būti organizuojamas saugus patekimas iki VT stotelès.

\subsection{Antrojo skyriaus išvados}

1. Nustatyta, kad daugiabučių namų gyvenamuosiuose rajonuose nakties metu nuo $2,2 \%$ iki $18,4 \%$ automobilių stovi neleistinose vietose. Stovinčių automobilių tankis gyvenamosiose teritorijose siekia nuo 35,2 aut./ha iki 61,0 aut./ha. Pavyzdžiui, Lazdynų gyvenamajame rajone leistinose vietose galètų stovèti 30,0 aut./ha, o Pilaiteje $-54,0$ aut./ha.

2. Nustatyta, kad Vilniaus miesto prekybos centrų automobilių stovejjimo aikštelèse užpildymo rodiklis nuo 22.00 val. vakaro iki 2.00 val. nakties - $27 \%$. Tai reiškia, kad planuojant prekybos centrų automobilių stovèjimo aikšteles daugiabučių namų gyvenamuosiuose rajonuose nèra atsižvelgiama i esamą užstatymą ir nebandoma kompleksiškai racionaliai naudoti žemès plotus automobiliams statyti. Todėl buvo sudaryta prekybos centrų automobilių stovejjimo aikštelių kriterijų visuma, kurie leidžia nustatyti veiksnius ir padidinti juose užpildymo rodiklị. 
3. Lietuvos didmiesčiuose pastebèta, kad gyventojų lokalioji mobilumo erdvè didèja ir vis daugiau jų keliasi gyventi iš miesto ị priemiestį. Dèl šios priežasties išaugo važiuojančių iš priemiestinès zonos i miesto centrą automobilių srautai. Rasti racionalų būdą aptarnauti retai apgyvendintą teritoriją viešuoju transportu priemiestinèje teritorijoje pasiūlytos 3 statyk ir važiuok sistemos koncepcijos. Šių koncepcijų pagrindiniai skirtumai yra aikštelę aptarnaujančio viešojo transporto dažnis ir greitis. Taip pat sudarytas šio sistemos automobilių stovejjimo aikštelès teorinis modelis, leidžiantis parinkti statyk ir važiuok sistemos aikštelès išdèstymo vietą miesto teritorijoje.

4. Siekiant pagerinti automobilių statymą atskirose miesto teritorijose sudaryta automobilių stovejjimo vietų mieste kriterijų sistema. Taikant daugiatikslius vertinimo metodus buvo nustatyta, atskirų kriterijų svarba ir prioritetinè seka. Daugiausiai įtakos A (gyvenamieji rajonai) grupeje turi automobilizacijos lygis $(0,287)$ ir viešojo transporto išvystymo lygis $(0,214)$, B (prekybos centrai) grupejje - automobilių stovejjimo vietu poreikis $(0,3452)$ ir butų skaičius $(0,2058), \mathrm{C}$ (statyk ir važiuok sistema) grupejje - viešojo transporto tinklo išvystymas $(0,157)$ ir važiavimo trukmè viešuoju transportu $(0,148)$. 



\section{Miesto automobilių stovejjimo vietụ efektyvumo vertinimas}

Trečiajame skyriuje, remiantis atliktų tyrimų rezultatais ir apskaičiuotais ASV kriterijų svorių koeficientais, taikomi daugiatiksliai vertinimo metodai: COPRAS, SAW, TOPSIS ir PROMETHEE. Sukurta PC ASA vertinimo sistema, kuri leidžia sumažinti nelegaliai stovinčių automobilių skaičių daugiabučiu namų teritorijose. Pasiūlyta SV sistemos ASA mieste sisteminès atrankos strategija ir pateikti trys originalūs ASA koncepciniai modeliai, kurie pritaikyti realiai didmiesčio erdvei.

Šio skyriaus tema publikuoti du straipsniai (Burinskienè et al. 2014; Palevičius and Lazauskaitė 2014).

\subsection{Sprendimo prièmimo duomenys automobilių stovèjimo vietų gyvenamuosiuose rajonuose daugiatiksliam vertinimui}

ASA užima didžiules miesto teritorijas, tačiau jos būtinos TP stovèti. AS tvarka turi padèti pasiekti užsibrèžtą tikslą, susijusị su miesto teritorijos tvarkymu, transportu, finansiniais ištekliais ir aplinka. Priimti sprendimai turi būti 
suprantami visos miesto plètros, teritorinio bei eismo planavimo strategijos kontekste.

3.1 lentelè. Sprendimo prièmimo duomenys daugiatiksliam vertinimui

Table 3.1. Decision-making data for multipurpose evaluation

\begin{tabular}{|c|c|c|c|c|c|c|c|c|c|c|}
\hline \multirow[b]{2}{*}{ 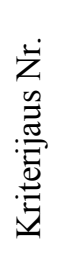 } & \multirow[b]{2}{*}{ 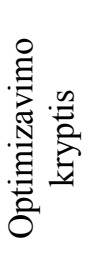 } & \multirow[b]{2}{*}{ 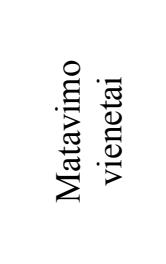 } & \multicolumn{8}{|c|}{ Gyvenamieji rajonai } \\
\hline & & & 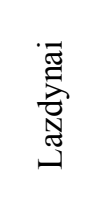 & 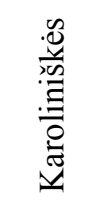 & 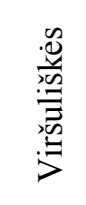 & 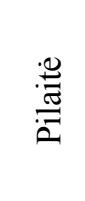 & 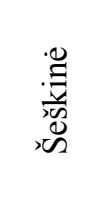 & 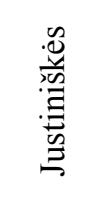 & 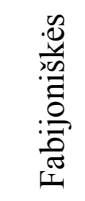 & 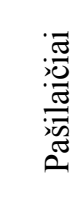 \\
\hline $\mathrm{A}_{1}$ & - & $\begin{array}{c}\text { aut./ } \\
1000 \text { gyv. }\end{array}$ & 434 & 395 & 375 & 358 & 429 & 380 & 443 & 470 \\
\hline $\mathrm{A}_{2}$ & + & balai & 7 & 8 & 9 & 6 & 8 & 8 & 7 & 7 \\
\hline $\mathrm{A}_{3}$ & + & $\begin{array}{l}\text { tūkst. gyv. } \\
\text { /ha }\end{array}$ & 30 & 72 & 57 & 24 & 79 & 163 & 95 & 83 \\
\hline $\mathrm{A}_{4}$ & - & ha & 133 & 173 & 81 & 203 & 143 & 138 & 212 & 144 \\
\hline $\mathrm{A}_{5}$ & + & tūkst. vnt. & 30,2 & 28,6 & 15,2 & 21,4 & 36,2 & 30,8 & 35,0 & 27,3 \\
\hline $\mathrm{A}_{6}$ & + & $\begin{array}{l}\mathrm{km} / \\
\mathrm{km}^{2}\end{array}$ & 3,09 & 3,26 & 3,45 & 2,42 & 3,58 & 3,85 & 4,40 & 3,64 \\
\hline $\mathrm{A}_{7}$ & + & tūkst. vnt. & 7,0 & 7,9 & 5,0 & 5,6 & 6,0 & 5,7 & 6,0 & 5,5 \\
\hline $\mathrm{A}_{8}$ & + & tūkst. vnt. & 7,2 & 7,2 & 7,3 & 6,0 & 9,2 & 4,6 & 9,3 & 9,0 \\
\hline
\end{tabular}

Daugiatikslio vertinimo metodai ASV miestuose planavimo srityje gali būti taikomi įvertinant ASV esamą padètį, jų skaičiaus plètrą ir jos pasekmes bendrai miesto susisiekimo sistemai. Remiantis nustatytais kriterijų svoriais (3.1 lentelè) ir juos toliau skaičiuojant daugiatiksliais vertinimo metodais, šiame darbe bus atlikta ASV gyvenamuosiuose rajonuose daugiatikslè analizé, kuri vèliau bus ivertinta ir taikoma galutiniams autoriaus darbo rezultatams pasiekti.

Siekiant užtikrinti pakankamą ASV skaičių centrinèje, vidurinëje ir priemiestinèje miesto zonose, skaičiavimams taikomos sprendimų paramos sistemos. Nustatytiems kriterijams priskiriamos optimizavimo kryptys 
(minimizavimas arba maksimizavimas), svoriai, nurodomi matavimo vienetai ir suvedamos skaitinès reikšmès (3.1 lentelè).

\subsection{Daugiatikslis vertinimas COPRAS, SAW, TOPSIS ir rezultatu apibendrinimas vidurkio metodais}

Toliau šiame darbe taikomi daugiatiksliai sprendimo priemimo metodai: COPRAS, SAW ir TOPSIS. Šie metodai plačiai taikomi vadybos, technologijos ir statybos srityse (Turskis and Zavadskas 2010).

COPRAS metodas. COPRAS sukurtas $1996 \mathrm{~m}$. Vilniaus Gedimino technikos universiteto mokslininkų Zavadsko ir Kaklausko (Zavadskas and Kaklauskas 1996).

Šis metodas iki šiol nebuvo taikytas ASA efektyvumui nustatyti, bet jis plačiai naudojamas moksliniuose straipsniuose. Pavyzdžiui, Europos šalių statybos sektoriaus prioritetiškumui nustatyti (Kildienè et al. 2011), statybos projektuose (Kanapeckienė et al. 2010), pažangioje urbanistinejje aplinkoje (Kaklauskas et al. 2010), apleistų pastatų rangavimui (Antuchevičienė et al. 2011, 2012) ir kitose pritaikomujų mokslo šakų straipsniuose.

Šio metodo esmé ta, kad visų rodiklių $R_{i}$ reikšmes $r_{i j}$ galima susieti ị vieną kiekybini vertinimą - metodo kriterijaus reikšmę, jei jie nepriklauso nuo matavimo vienetų, tai yra bedimensiniai. Dauguma metodų taikomi pradinių duomenų $r_{i j}$ skirtingam pertvarkymui, nors pertvarkytos reikšmės $r_{i j}$ kinta dažniausiai nuo 0 iki 1 . Skaičiuojant COPRAS metodu naudojamas klasikinis normalizavimas (Podvezko 2011):

$$
\widetilde{r}_{i j}=\frac{r_{i j}}{\sum_{j=1}^{n} r_{i j}}\left(i=1, \ldots, m ; j=1, \ldots, n ; \sum_{j=1}^{n} \widetilde{r}_{i j}=1\right) .
$$

Skaičiuojant šiuo metodu nagrinejjamų variantų prioritetiškumas ir jų naudingumo laipsnis tiesiogiai ir proporcingai priklauso nuo alternatyvas adekvačiai apibūdinančių kriterijų sistemos, kriterijų reikšmių ir reikšmingumo dydžių. Skaičiavimai atliekami penkiais žingsniais:

1-as žingsnis:

$$
d_{i j}=\frac{r_{i j} \cdot \omega_{i}}{\sum_{j=1}^{n} r_{i j}}, \quad i=\overline{1, m} ; \quad j=\overline{1, n},
$$


čia $r_{i j}-i$-jo kriterijaus reikšme $j$-jo sprendimo alternatyvos variantu, $m-$ kriterijų skaičius, $n$ - lyginamujų variantų skaičius, $\omega_{i}-i$-jo kriterijaus normalizuotas svoris.

2-as žingsnis. Apskaičiuojamos j variantą apibūdinančių minimizuojančių $S_{-j}$ ir maksimizuojančių $S_{+j}$ ịvertintų normalizuotų kriterijų sumos. Jos apskaičiuojamos pagal formulę:

$$
S_{+j}=\sum_{i=1}^{m} d_{+i j} ; \quad S_{-j}=\sum_{i=1}^{m} d_{-i j} ; \quad i=\overline{1, m} ; \quad j=\overline{1, n} .
$$

3-as žingsnis. Lyginamas variantų santykinis reikšmingumas (efektyvumas), nustatomas remiantis juos apibūdinančiomis teigiamomis $S_{+j}$ ir neigiamomis $S_{-j} \quad$ savybėmis. Kiekvieno varianto $a_{j}$ santykinis reikšmingumas $Q_{j}$ nustatomas pagal formulę:

$$
Q_{j}=S_{+j}+\frac{S_{-\min } \cdot \sum_{j=1}^{n} S_{-j}}{S_{-j} \sum_{j=1}^{n} \frac{S_{-\min }}{S_{-j}}} \quad j=\overline{1, n} .
$$

3.2 lentelè. COPRAS metodu gauta prioritetu eilè

Table 3.2. Priority order obtained by the COPRAS method

\begin{tabular}{lcc}
\hline \multicolumn{1}{c}{ Gyvenamojo rajono pavadinimas } & $Q_{j}$ & Gyvenamojo rajono rangas \\
\hline Justiniškès & 0,1501 & 1 \\
\hline Šeškinė & 0,1349 & 2 \\
\hline Fabijoniškès & 0,1290 & 3 \\
\hline Viršuliškès & 0,1286 & 4 \\
\hline Karoliniškès & 0,1285 & 5 \\
\hline Pašilaičiai & 0,1217 & 6 \\
\hline Lazdynai & 0,1170 & 7 \\
\hline Pilaitė & 0,1032 & 8 \\
\hline
\end{tabular}

4-as žingsnis. Nustatoma variantų prioritetų eilès tvarka. Kuo didesnis $Q_{j}$, tuo varianto efektyvumas yra didesnis.

5-as žingsnis. Apskaičiuojamas varianto naudingumo laipsnis: 


$$
N_{j}=\frac{Q_{j}}{Q_{\max }} \cdot 100 .
$$

Čia $N_{j}$ - naudingumo laipsnis, $\%$.

Atlikus skaičiavimus pagal COPRAS metodą nustatyta, kad nagrinėjamuose gyvenamuosiuose rajonuose geriausios LA laikymo sąlygos yra Justiniškių rajone (3.2 lentelè), blogiausia situacija - Pilaitès rajone.

SAW metodas. Daugiatikslių vertinimo metodų taikymo praktika rodo, kad objektų rangavimas, remiantis skirtingais metodais, dažnai sutampa arba mažai skiriasi. SAW metodas labai plačiai naudojamas moksliniuose straipsniuose. Šiuo metodu skaičiavimus atliko ir ASV trūkumo problemas sprende Bekker ir Viviers (Bekker and Viviers 2008).

Pradiniu vertinimo etapu galima rekomenduoti taikyti paprasčiausią metodą VS - vietų sumą: jo rezultatai (objektų rangavimas) dažnai mažai skiriasi nuo sudètingų matematinių metodų rezultatų, nors skaičiavimas paprastas ir nereikalauja kompiuterinių programų (Podvezko 2008).

VS metodo kriterijus $V_{j}$ skaičiuojamas pagal formulę:

$$
V_{j}=\sum_{i=1}^{m} m_{i j},
$$

čia $m_{i j}-i$-ojo kriterijaus vieta $j$-jam objektui. Geriausia kriterijaus $V_{j}$ reikšmè yra mažiausia.

Kiekybinių daugiatikslių metodų ideją gerai parodo SAW metodas (Hwang and Yoon 1981). Šio metodo kriterijus $S_{j}$ yra pasvertujų kriterijų reikšmių suma:

$$
S_{j}=\sum_{i=1}^{m} \omega_{i} \widetilde{r}_{i j}
$$

čia $\omega_{i}-i$-ojo kriterijaus svoris; $\widetilde{r}_{i j}-i$-ojo kriterijaus normalizuota reikšmé $j$ jam objektui. Geriausia kriterijaus $S_{j}$ reikšmė yra didžiausia.

Atlikus skaičiavimus pagal SAW metodą nustatyta, kad nagrinejjamuose gyvenamuosiuose rajonuose geriausios LA laikymo sąlygos yra Justiniškių rajone, blogiausia situacija - Pilaitès rajone (3.3 lentelè). 
3.3 lentelè. SAW metodu gauta prioritetų eilè

Table 3.3. Priority order obtained by the SAW method

\begin{tabular}{lcc}
\hline \multicolumn{1}{c}{ Gyvenamojo rajono pavadinimas } & $S_{j}$ & Gyvenamojo rajono rangas \\
\hline Justiniškès & 0,1493 & 1 \\
\hline Šeškinė & 0,1341 & 2 \\
\hline Viršuliškès & 0,1307 & 3 \\
\hline Fabijoniškès & 0,1290 & 4 \\
\hline Karoliniškès & 0,1280 & 5 \\
\hline Pašilaičiai & 0,1212 & 6 \\
\hline Lazdynai & 0,1164 & 7 \\
\hline Pilaitė & 0,1043 & 8 \\
\hline
\end{tabular}

TOPSIS metodas. Tai artumo idealiam taškui sprendimo prièmimo metodas, kuris sukurtas $1981 \mathrm{~m}$. Sprendžiant šiuo metodu pasirinkta geriausia alternatyva turi mažiausią atstumą iki geriausio sprendimo ir didžiausią atstumą iki blogiausio sprendimo (Hwang and Yoon 1981). Šis metodas yra pagristas stipriu matematiniu skaičiavimu, todèl labai plačiai naudojamas inžinerinių mokslų darbuose. TOPSIS metodas naujausioje mokslineje literatūroje taikomas žemès kasyboje (Fouladgar et al. 2011), renovacijoje (Fouladgar et al. 2012a,b, Lashgari et al. 2012, Kalibatas et al. 2011, Medineckiene and Bjork 2011) ir kitose inžinerinèse mokslo srityse.

Pirmojo etapo skaičiavimas atliekamas pagal formulę:

$$
\tilde{r}_{i j}=\frac{r_{i j}}{\sqrt{\sum_{j=1}^{n} r_{i j}^{2}}}(i=1, \ldots, m ; j=1, \ldots, n),
$$

čia $\widetilde{r}_{i j}-i$-ojo kriterijaus $j$-ojo objekto normalizuota reikšmè.

Geriausias sprendinys (variantas) $V^{*}$ ir blogiausias $-V^{-}$skaičiuojami pagal formules:

$$
\begin{gathered}
V^{*}=\left\{V_{1}^{*}, V_{2}^{*}, \ldots V_{m}^{*}\right\}=\left\{\left(\max \omega_{i} \widetilde{r}_{i_{j}} / i \in I_{1}\right),\left(\min \omega_{i} \widetilde{r}_{i_{j}} / i \in I_{2}\right)\right\}, \\
V^{-}=\left\{V_{1}^{-}, V_{2}^{-}, \ldots V_{m}^{-}\right\}=\left\{\left(\min \omega_{i} \widetilde{r}_{i_{j}} / i \in I_{1}\right),\left(\max \omega_{i} \widetilde{r}_{i_{j}} / i \in I_{2}\right)\right\} .
\end{gathered}
$$


čia $I_{1}$ - maksimizuojamųų rodiklių indeksų aibè, $I_{2}-$ minimizuojamujų rodiklių indeksų aibè.

3.4 lentelè. TOPSIS metodu gauta prioritetu eilè

Table 3.4. Priority order obtained by the TOPSIS method

\begin{tabular}{lcc}
\hline \multicolumn{1}{c}{ Gyvenamojo rajono pavadinimas } & $C_{j}^{*}$ & Gyvenamojo rajono rangas \\
\hline Justiniškès & 0,785 & 1 \\
\hline Šeškinè & 0,552 & 2 \\
\hline Fabijoniškès & 0,509 & 3 \\
\hline Karoliniškès & 0,469 & 4 \\
\hline Viršuliškės & 0,437 & 5 \\
\hline Pašilaičiai & 0,430 & 6 \\
\hline Lazdynai & 0,355 & 7 \\
\hline Pilaitė & 0,265 & 8 \\
\hline
\end{tabular}

Skaičiuojamas kiekvieno lyginamo varianto bendras atstumas $D_{j}^{*}$ iki geriausių sprendinių ir $D_{j}^{-}$iki blogiausių sprendinių pagal formules:

$$
\begin{aligned}
& D_{j}^{*}=\sqrt{\sum_{i=1}^{m}\left(\omega_{i} \widetilde{r}_{i j}-V_{i}^{*}\right)^{2}}, \\
& D_{j}^{-}=\sqrt{\sum_{i=1}^{m}\left(\omega_{i} \widetilde{r}_{i j}-V_{i}^{-}\right)^{2}} .
\end{aligned}
$$

Toliau TOPSIS metodu skaičiuojamas kriterijus $C_{j}^{*}$, kuris nustatomas pagal formulę:

$$
C_{j}^{*}=\frac{D^{-}}{D_{j}^{*}+D_{j}^{-}}(j=1, \ldots, n), \quad\left(0 \leq C_{j}^{*} \leq 1\right) .
$$

Atlikus skaičiavimus, geriausiam variantui atitinka didžiausia kriterijaus $C_{j}^{*}$ reikšmė Justiniškiu rajone $(0,785)$. Detalesni TOPSIS metodo skaičiavimo duomenys pateikti 3.4 lentelèje.

Vidurkio metodas. Trimis metodais (COPRAS, SAW ir TOPSIS) gauti skaičiavimų rezultatai yra labai panašūs, bet skirtingi (3.5 lentelè). Tokị 
rezultatų skirtumą gali lemti: fizinè kriterijų reikšmè, matematinès ir programinès įrangos lygis ir ịvairios subjektyvios aplinkybès.

3.5 lentelè. Vidurkio metodu gauta prioritetų eilè

Table 3.5. Priority order obtained by the average method

\begin{tabular}{lccccc}
\hline \multirow{2}{*}{$\begin{array}{c}\text { Gyvenamieji } \\
\text { rajonai }\end{array}$} & $\begin{array}{c}\text { Natūrinis } \\
\text { tyrimas }\end{array}$ & $\begin{array}{c}\text { COPRAS } \\
\text { metodas }\end{array}$ & $\begin{array}{c}\text { SAW } \\
\text { metodas }\end{array}$ & $\begin{array}{c}\text { TOPSIS } \\
\text { metodas }\end{array}$ & $\begin{array}{c}\text { Vidurkio } \\
\text { metodas }\end{array}$ \\
\hline Lazdynai & 8 & 7 & 7 & 7 & 7,25 \\
\hline Karoliniškès & 2 & 5 & 5 & 4 & 4 \\
\hline Viršuliškès & 4 & 4 & 3 & 5 & 4 \\
\hline Pilaite & 7 & 8 & 8 & 8 & 7,75 \\
\hline Šeškinè & 6 & 2 & 2 & 1 & 2,75 \\
\hline Justiniškès & 5 & 1 & 1 & 1 & 2 \\
\hline Fabijoniškès & 3 & 3 & 4 & 3 & 3,25 \\
\hline Pašilaičiai & 1 & 6 & 6 & 6 & 4,75 \\
\hline & & & & & \\
\hline
\end{tabular}

Siekiant išsiaiškinti, kuriuose rajonuose LA laikymo sąlygos yra geriausias, o kuriuose blogiausios, taikysime vidurkio metodą. I skaičiavimus, atliekamus pagal ši metodą, įtraukiami natūrinių tyrimų rezultatai. Priimta, kad didžiausias procentas stovinčiu neleistinose vietose LA yra mažiausias rangas (Pilaitès rajonas), o Pašilaičių rajone suteiktas didžiausias rangas, nes stovinčių LA skaičius neleistinose vietose mažiausias.

Daugiatikslio sprendimo prièmimo metodais gautus rezultatus ir natūrinių tyrimų rezultatus apskaičiavus vidurkio metodu nustatyta, kad geriausios LA stovėjimo sąlygos yra Justiniškių rajone, o blogiausios - Pilaitės rajone.

\subsection{Sprendimo prièmimo duomenys, automobilių stovèjimo vietų prekybos centruose, daugiatiksliam vertinimui}

Vilniuje per paskutinị dešimtmetị intensyviai augo tokių PC skaičius, prie kurių buvo ịrengiamos didelès ASA. PC plètra suformavo naują struktūrinį, labai koncentruotą miesto elementą, kurio veiklos pasekmė mažai nagrinèta transportiniu požiūriu. Remiantis darnios miestu plètros principais, autoriaus siekis yra suderinti PC ASA efektyvų panaudojimą visos paros metu. Dèl to atliktas tyrimas, kurio metu buvo visapusiškai išanalizuotos 49 Vilniaus miesto PC ASA. Ekspertų apklausos metu atrinkti 7 kriterijai (3.1 pav.), kurie charakterizuoja PC ASA sąsają su daugiaaukščio užstatymo teritorija. Nustatyta 
PC stovejjimo aikštelių projektinè talpa, jų užpildymas, papildomai nustatytas 300 metrų spindulių nuo PC ASA gyventojų skaičius, butų skaičius, butų vertė, dirbančiųjų skaičius, ASV poreikis, PC ASA užpildymo koeficientai.

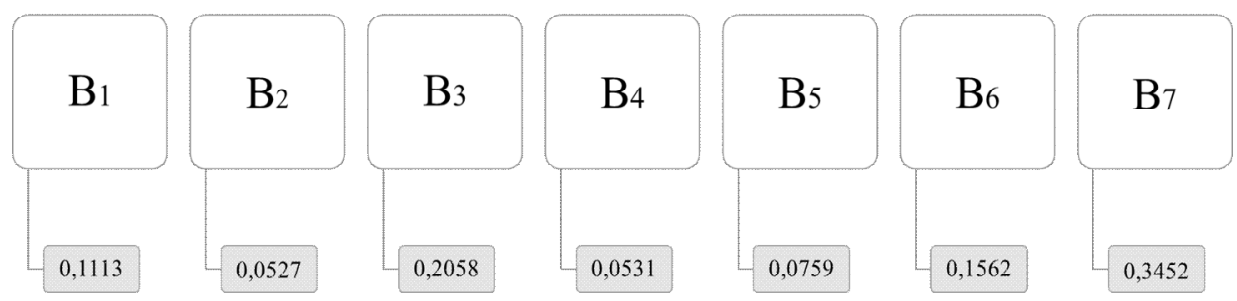

3.1 pav. Prekybos centrų automobilių stovèjimo aikštelių kriterijų svoriai

Fig. 3.1. Weights of criteria of car parking's of shopping centers

Planuojant gyvenamajame rajone statyti PC su ASA, turi būti įvertintas jos poveikis SS infrastruktūrai. Siekiant gauti vienareikšmišką atsakymą, kokio dydžio ASA galima statyti, o kokio - nepageidautina, reikia mokslinio pagrindimo. Tradicinès vertinimo sistemos neturi galimybių tiksliai įvertinti daugybès veiksnių, todèl vertinimas atliekamas taikant daugiatikslès vertinimo metodus.

Taikydami daugiatikslio vertinimo metodą, naudosime 2.2.4 skyriuje suskaičiuotus kriterijų svorius (3.1 pav.).

Natūriniams tyrimams buvo pasirinktos 49 PC ASA Vilniaus mieste. Atlikus natūrinius tyrimus nustatyta, kad PC aikštelèse užpildymo koeficientai svyruoja nuo $1 \%$ iki $100 \%$. Siekiant lengviau atlikti skaičiavimus, PC aikštelès buvo suskirstytos ị keturias grupes pagal ASA užpildymo koeficientus:

I-jai grupei priskiriamos 8 PC ASA, kurių užimtumas svyruoja nuo $76 \%$ iki $100 \%$. II-jai grupei - 8 ASA, užimtumas nuo $51 \%$ iki $75 \%$. III-jai - 13 aikštelių, užimtumas nuo $26 \%$ iki $50 \%$. IV-jai - 20 aikštelių, užimtumas nuo $0 \%$ iki $25 \%$.

Suskirsčius PC ASA ị keturias grupes, suvedamos skaitinès (normalizuotos) kriterijų reikšmès, kurios pateiktos A priedo A1-A4 lentelèse.

I-jai grupei priskirtos 8 PC ASA, kuriose nuo 22.00 val. vakaro iki 2.00 val. nakties užpildymas siekè nuo 83 iki $100 \%$ (A1 lentelè).

II-jai grupei priskirtos 8 PC aikštelès, kuriose užpildymas siekè nuo 54 iki $67 \%$ (A2 lentelè)

III-jai grupei priskirta 13 PC aikštelių, kuriose užpildymas siekė nuo 27 iki $48 \%$ (A3 lentelè).

IV-jai grupei priskirta 20 PC ASA, kuriose užpildymas siekè nuo 1 iki $23 \%$ (A4 lentelè). 
Remiantis A1-A4 lentelès duomenimis, toliau skaičiuojama daugiatiksliais vertinimo metodais: SAW, TOPSIS ir PROMETHEE.

\subsubsection{Daugiatikslis vertinimas, SAW, TOPSIS ir PROMETHEE metodais}

Siekiant kuo objektyviau įvertinti sistemingą PC ASA plètrą, kuri iš dalies padètų spręsti ASV trūkumo problemas daugiabučių namų gyvenamuosiuose rajonuose, taikomi daugiatiksliai vertinimo metodai: SAW, TOPSIS ir PROMETHEE. Skaičiavimai yra atliekami remiantis sudarytomis sprendimo prièmimo duomenų lentelėmis (A1-A4 lentelèmis) ir apskaičiuotais kriterijų svoriais.

Skaičiavimai SAW metodu atliekami remiantis 3.2 poskyryje pateiktomis (3.6)-(3.7) formulèmis. Taip pat, remiantis 3.2 poskyryje pateiktomis (3.9)(3.12) formulèmis skaičiuojama ir TOPSIS metodu.

PROMETHEE metodas. Kaip trečiajji metodą taikysime PROMETHEE (angl. Preference Ranking Organisation Method for Enrichment Evaluation), kurị 1982 m. pasiūlè belgų mokslininkas Brans, o vèliau prisijungè Mareschal (Brans and Mareschal 2005).

Lietuvoje šis metodas yra žinomas, jis yra paminètas $2004 \mathrm{~m}$. (Ustinovičius and Zavadskas 2004), vèliau ji plačiai išnagrinèjo ir aprašè mokslininkai Podvezko (Podvezko, Podviezko 2010a, b).

Šis metodas vietoj normalizuotų reikšmių taiko taip vadinamos prioritetų funkcijos reikšmes, kurios argumentas $d$ yra dviejų lyginamų alternatyvų rodiklio reikšmių skirtumas, tai yra atstumas tarp jų. Ši funkcija priklauso nuo dviejų parametrų - indiferentiškumo ribos $q$ ir prioritetiškumo ribos $s$ (3.2 pav.).

PROMETHEE metodai lygina visas $A_{j}$ ir $A_{k}$ alternatyvas, skaičiuojant rangavimo santykị $\pi\left(A_{j}, A_{k}\right)$, kuris skaičiuojamas pagal formulę:

$$
\pi\left(A_{j}, A_{k}\right) \sum_{i=1}^{m} \omega_{i} p_{t}\left(d_{i}\left(A_{j}, A_{k}\right)\right),
$$

čia $\omega_{i}-i$-jo kriterijaus $R_{i}$ svoris (reikšmingumas), $d_{i}\left(A_{j}, A_{k}\right)=r_{i j}-r_{i k}-$ alternatyvu $A_{j}$ ir $A_{k}$ i-jo kriterijaus $R_{i}$ reikšmiu $r_{i j}$ ir $r_{i k}$ skirtumas; $p_{t}(d)=p_{t}\left(d_{i}\left(A_{j}, A_{k}\right)\right)-t$-ja prioritetu funkcija, pasirinktoji $i$-jam kriterijui. PROMETHEE metodai vertina kiekvienos $j$-os alternatyvos visų ,išeinančių“ santykių sumas:

$$
F_{j}^{+}=\sum_{k=1}^{n} \pi\left(A_{j}, A_{k}\right),
$$


Vèliau ir visų ,ieinančių“ santykių sumas:

$$
F_{j}^{-}=\sum_{k=1}^{n} \pi\left(A_{j}, A_{k}\right)(j=1,2 \ldots, n) .
$$

$$
p(d)=\left\{\begin{array}{l}
0, \text { kai } d \leq q \\
\frac{d-q}{s-q}, \text { kai } q<d \leq s \\
1, \text { kai } d>s
\end{array}\right.
$$

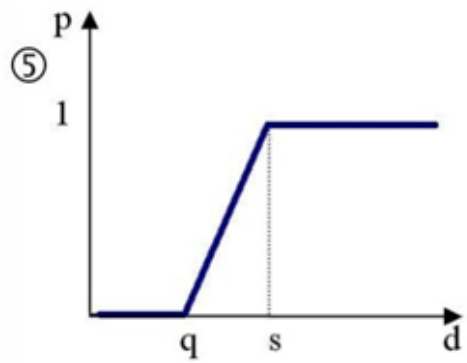

3.2 pav. V pavidalo funkcija su identiškumo sritimi

Fig. 3.2. V-shape function with indifference preference

PROMETHEE II metodas skaičiuoja $F_{j}^{+}$ir $F_{j}^{-}$santykių skirtumus $F_{j}=F_{j}^{+}-F_{j}^{-}$ir ranguoja alternatyvas mažèjančia dydžių skirtumų $F_{j}$ eilès tvarka. Iš dažniausiai praktikoje taikomų prioritetų funkcijų $p(d)$ šiame darbe mes pasirinkome visiems kriterijams geriausiai tinkama taip vadinama $\mathrm{V}$ pavidalo su identiškumo sritimi funkciją (3.2 pav.).

3.6 lentelè. I-osios grupès automobilių stovejimo aikštelių vertinimo rezultatai naudojant SAW, TOPSIS ir PROMETHEE metodus

Table 3.6. Results of the evaluation of car parking's of group I by SAW, TOPSIS and

\begin{tabular}{|c|c|c|c|c|c|c|c|c|c|c|}
\hline \multirow{3}{*}{$\begin{array}{l}\mathrm{PC} \\
\mathrm{Nr} .\end{array}$} & \multicolumn{8}{|c|}{ Metodai } & \multirow{3}{*}{$\begin{array}{l}\text { Vietų } \\
\text { suma }\end{array}$} & \multirow{3}{*}{$\stackrel{\frac{\pi}{2}}{\stackrel{2}{\circ}}$} \\
\hline & \multicolumn{2}{|c|}{ SAW } & \multicolumn{2}{|c|}{ TOPSIS } & \multicolumn{4}{|c|}{ PROMETHEE } & & \\
\hline & $S_{j}$ & V & $C_{j}^{*}$ & V & $F_{j}^{+}$ & $F_{j}^{-}$ & $F_{j}$ & $\mathrm{~V}$ & & \\
\hline 1. & 0,1270 & 4 & 0,4014 & 5 & 1,170 & 1,479 & $-0,309$ & 4 & 13 & 4 \\
\hline 2. & 0,1467 & 2 & 0,6356 & 2 & 2,346 & 0,875 & 1,471 & 2 & 6 & 2 \\
\hline 3. & 0,0983 & 8 & 0,2699 & 8 & 0,480 & 2,176 & $-1,696$ & 8 & 24 & 8 \\
\hline 4. & 0,1309 & 3 & 0,4398 & 4 & 1,362 & 1,541 & $-0,179$ & 3 & 10 & 3 \\
\hline 5. & 0,1540 & 1 & 0,7322 & 1 & 2,610 & 0,396 & 2,214 & 1 & 3 & 1 \\
\hline 6. & 0,1066 & 7 & 0,4608 & 3 & 1,748 & 2,266 & $-0,518$ & 6 & 16 & 5 \\
\hline 7. & 0,1166 & 6 & 0,3911 & $6-7$ & 1,198 & 1,548 & $-0,350$ & 5 & 17,5 & 6 \\
\hline 8. & 0,1202 & 5 & 0,3911 & $6-7$ & 0,951 & 1,583 & $-0,632$ & 7 & 18,5 & 7 \\
\hline
\end{tabular}
PROMETHEE methods 
SAW, TOPSIS ir PROMETHEE metodais gautos kiekvienos grupès visų ASA vertinimo kriterijų reikšmès, atitinkamos vietos, vietų sumos ir apibendrintas įvertinimas (rangavimas) pateikti 3.6-3.9 lentelèse.

3.7 lentelè. II-osios grupès automobilių stovèjimo aikštelių vertinimo rezultatai naudojant SAW, TOPSIS ir PROMETHEE metodus

Table 3.7. Results of the evaluation of car parking's of group II by SAW, TOPSIS and PROMETHEE methods

\begin{tabular}{|c|c|c|c|c|c|c|c|c|c|c|}
\hline \multirow{3}{*}{$\begin{array}{l}\mathrm{PC} \\
\mathrm{Nr} .\end{array}$} & \multicolumn{8}{|c|}{ Metodai } & \multirow{3}{*}{$\begin{array}{l}\text { Vietų } \\
\text { suma }\end{array}$} & \multirow{3}{*}{$\stackrel{\frac{\pi}{0}}{\stackrel{0}{>}}$} \\
\hline & \multicolumn{2}{|c|}{ SAW } & \multicolumn{2}{|c|}{ TOPSIS } & \multicolumn{4}{|c|}{ PROMETHEE } & & \\
\hline & $S_{j}$ & V & $C_{j}^{*}$ & $\mathrm{~V}$ & $F_{j}^{+}$ & $F_{j}^{-}$ & $F_{j}$ & $\mathrm{~V}$ & & \\
\hline 1. & 0,1493 & 3 & 0,5063 & 2 & 1,988 & 0,963 & 1,035 & 3 & 8 & 3 \\
\hline 2. & 0,1303 & 4 & 0,4065 & 4 & 1,508 & 1,911 & $-0,402$ & 6 & 14 & $4-5$ \\
\hline 3. & 0,1262 & 5 & 0,3886 & 5 & 1,848 & 1,118 & 0,730 & 4 & 14 & $4-5$ \\
\hline 4. & 0,1058 & 6 & 0,3003 & 6 & 1,256 & 1,376 & $-0,120$ & 5 & 17 & 6 \\
\hline 5. & 0,1560 & 2 & 0,4834 & 3 & 2,572 & 0,456 & 2,115 & 1 & 6 & 2 \\
\hline 6. & 0,0418 & 8 & 0 & 8 & 0 & 4,309 & $-4,309$ & 8 & 24 & 8 \\
\hline 7. & 0,1939 & 1 & 0,7262 & 1 & 3,316 & 1,271 & 2,045 & 2 & 4 & 1 \\
\hline 8. & 0,0963 & 7 & 0,2709 & 7 & 1,169 & 2,265 & $-1,094$ & 7 & 21 & 7 \\
\hline
\end{tabular}

Šiais metodais atliktų skaičiavimų rezultatai rodo, kad PC ASA I-osios grupès vertinimo rezultatai yra geriausi Žemynos gatvèje esančioje „Iki“ ASA. (3.6 lentelè). Tai sąlygoja 1,08 užstatymo intensyvumas, didelis - 1720 butų skaičius, 2470 dirbančiųjų gyventojų skaičius (300 metrų spinduliu nuo PC ASA). Aikštelè gerai matoma iš aplinkinių daugiabučiu namų butų, kas lemia, gyventojų požiūriu, saugesnị LA laikymą nakties metu. Nepalankiausia situacija šioje grupèje yra L. Asanavičiūtès gatvèje esančio PC ASA (3.6 lentelè). Tai paaiškinama mažesniu ASV poreikiu dèl mažesnio butų ir dirbančiųjų gyventojų skaičiaus.

Atlikus skaičiavimus nustatyta, kad tarp PC ASA, kuriose nustatytas užpildymas siekia nuo 51 iki $75 \%$ (II grupe), geriausi vertinimo rezultatai yra Savanoriu pr. PC „Norfa“ ASA (3.7 lentelè). Nors aikštelè šalia PC nuo 22.00 val. vakaro iki 8.00 val. ryto apmokestinta, bet šioje grupejje pirmają vietą nulëmé didelis ASV poreikis. Taip pat, ASA yra stebima vaizdo kameromis ir gerai matoma iš aplinkinių daugiabučių namų butų. 
3.8 lentelè. III-osios grupès automobilių stovèjimo aikštelių vertinimo rezultatai naudojant SAW, TOPSIS ir PROMETHEE metodus

Table 3.8. Results of the evaluation of car parking's of group III by SAW, TOPSIS and PROMETHEE methods

\begin{tabular}{|c|c|c|c|c|c|c|c|c|c|c|}
\hline \multirow{3}{*}{$\begin{array}{l}\mathrm{PC} \\
\mathrm{Nr} .\end{array}$} & \multicolumn{8}{|c|}{ Metodai } & \multirow{3}{*}{$\begin{array}{l}\text { Vietu } \\
\text { suma }\end{array}$} & \multirow{3}{*}{ Vieta } \\
\hline & \multicolumn{2}{|c|}{ SAW } & \multicolumn{2}{|c|}{ TOPSIS } & \multicolumn{4}{|c|}{ PROMETHEE } & & \\
\hline & $S_{j}$ & $\mathrm{~V}$ & $C_{j}^{*}$ & $\mathrm{~V}$ & $F_{j}^{+}$ & $F_{j}^{-}$ & $F_{j}$ & $\mathrm{~V}$ & & \\
\hline 1. & 0,0539 & 13 & 0,2198 & 13 & 0,252 & 3,455 & $-3,203$ & 13 & 39 & 13 \\
\hline 2. & 0,0841 & 4 & 0,5624 & 2 & 2,495 & 2,555 & $-0,060$ & 8 & 14 & $4-5$ \\
\hline 3. & 0,0614 & 11 & 0,2795 & 12 & 1,973 & 3,192 & $-1,219$ & 10 & 33 & 11 \\
\hline 4. & 0,0790 & 8 & 0,4632 & 7 & 2,893 & 1,440 & 1,453 & 4 & 19 & 7 \\
\hline 5. & 0,0761 & 9 & 0,3616 & 10 & 1,895 & 2,430 & $-0,534$ & 9 & 28 & 9 \\
\hline 6. & 0,0805 & 6 & 0,4172 & 8 & 3,211 & 3,164 & 0,047 & 7 & 21 & 8 \\
\hline 7. & 0,0872 & 2 & 0,5276 & 4 & 3,534 & 1,213 & 2,231 & 1 & 7 & 2 \\
\hline 8. & 0,0563 & 12 & 0,3306 & 11 & 1,657 & 3,375 & $-1,718$ & 11 & 34 & 12 \\
\hline 9. & 0,0853 & 3 & 0,5440 & 3 & 2,456 & 1,516 & 0,940 & 5 & 11 & 3 \\
\hline 10. & 0,0799 & 7 & 0,5258 & 5 & 3,036 & 2,154 & 0,882 & 6 & 18 & 6 \\
\hline 11. & 0,0652 & 10 & 0,4098 & 9 & 1,725 & 4,366 & $-2,641$ & 12 & 31 & 10 \\
\hline 12. & 0,0828 & 5 & 0,4719 & 6 & 2,884 & 1,233 & 1,651 & 3 & 14 & $4-5$ \\
\hline 13. & 0,1085 & 1 & 0,6165 & 1 & 3,941 & 1,859 & 2,082 & 2 & 4 & 1 \\
\hline
\end{tabular}

Sąlyginai nedidelis ASA užpildymas (nuo $26 \%$ iki $50 \%$ ) ir neefektyvus jų panaudojimas III grupès PC ASA. Mažą ASA užpildymo koeficientą sąlygoja šalia einančios intensyvaus eismo gatvès (A, B ir C kategorijos), nepatogus ASA pasiekiamumas, blogas aikštelès matomumas iš daugiabučių namų butų. Šioje grupeje geriausi vertinimo rezultatai gauti L. Asanavičiūtès gatvèje esančioje PC „Norfa“ ASA (3.8 lentelè).

Nuo 22.00 val. vakaro iki 2.00 val. nakties mažiausias užpildymo koeficientas (iki $25 \%$ ) yra IV-osios grupès PC ASA. Vertinimo rezultatai yra panašūs ị III grupès, tačiau šios PC ASA pasižymi labai dideliu ASV skaičiumi. Tai sąlygoja labai blogą pasiekiamumą pésčiomis iki daugiabučių namų. Taip pat dèl ASA dydžio, 300 metrų spinduliu vyrauja mažas užstatymo intensyvumas. Atlikus skaičiavimus daugiatikslio vertinimo metodu, nustatyta, kad šioje grupèje geriausią ịvertinimą gavo P. Lukšio gatveje esanti PC ASA (3.9 lentelè). 
3.9 lentelè. IV-osios grupès automobilių stovèjimo aikštelių vertinimo rezultatai naudojant SAW, TOPSIS ir PROMETHEE metodus

Table 3.9. Results of the evaluation of car parking's of group IV by SAW, TOPSIS and PROMETHEE methods

\section{Metodai}

\begin{tabular}{|c|c|c|c|c|c|c|c|c|c|c|}
\hline \multirow{2}{*}{$\begin{array}{l}\text { PC } \\
\text { Nr. }\end{array}$} & \multicolumn{2}{|c|}{ SAW } & \multicolumn{2}{|c|}{ TOPSIS } & \multicolumn{4}{|c|}{ PROMETHEE } & \multirow{2}{*}{$\begin{array}{l}\text { Vietu } \\
\text { suma }\end{array}$} & \multirow[t]{2}{*}{ Vieta } \\
\hline & $S_{j}$ & $\mathrm{~V}$ & $C_{j}^{*}$ & $\mathrm{~V}$ & $F_{j}^{+}$ & $F_{j}^{-}$ & $F_{j}$ & $\mathrm{~V}$ & & \\
\hline 1 & 0,0501 & 13 & 0,4336 & 7 & 2,381 & 2,942 & $-0,561$ & 13 & 33 & 12 \\
\hline 2 & 0,0532 & 10 & 0,3352 & 13 & 4,340 & 3,277 & 1,062 & 9 & 32 & 11 \\
\hline 3 & 0,0645 & 3 & 0,4674 & 3 & 4,046 & 1,018 & 3,029 & 4 & 10 & 3 \\
\hline 4 & 0,0539 & 9 & 0,3904 & 10 & 2,525 & 1,420 & 1,035 & 10 & 29 & $9-10$ \\
\hline 5 & 0,0548 & 8 & 0,4329 & 8 & 2,724 & 2,285 & 0,438 & 12 & 28 & 8 \\
\hline 6 & 0,0334 & 16 & 0,1849 & 19 & 0,934 & 4,821 & $-3,887$ & 18 & 53 & 18 \\
\hline 7 & 0,0624 & 4 & 0,4060 & 9 & 4,000 & 2,893 & 1,107 & 8 & 21 & 7 \\
\hline 8 & 0,0312 & 17 & 0,1908 & 18 & 0,370 & 4,554 & $-4,184$ & 19 & 54 & 19 \\
\hline 9 & 0,0456 & 14 & 0,2868 & 17 & 2,264 & 4,584 & $-2,320$ & 15 & 46 & $14-15$ \\
\hline 10 & 0,0587 & 6 & 0,4605 & 6 & 2,965 & 1,459 & 1,506 & 6 & 18 & $5-6$ \\
\hline 11 & 0,0770 & 1 & 0,6036 & 1 & 5,048 & 1,930 & 3,118 & 3 & 5 & 1 \\
\hline 12 & 0,0551 & 7 & 0,3865 & 17 & 3,845 & 1,451 & 2,394 & 5 & 29 & $9-10$ \\
\hline 13 & 0,0305 & 18 & 0,3189 & 14 & 2,122 & 4,840 & $-2,718$ & 16 & 48 & 16 \\
\hline 14 & 0,0502 & 12 & 0,3783 & 12 & 2,453 & 1,767 & 0,686 & 11 & 35 & 13 \\
\hline 15 & 0,0507 & 11 & 0,4625 & 5 & 6,431 & 3,113 & 3,318 & 2 & 18 & $5-6$ \\
\hline 16 & 0,0708 & 2 & 0,4637 & 4 & 5,214 & 1,067 & 4,147 & 1 & 7 & 2 \\
\hline 17 & 0,0290 & 20 & 0,2908 & 15 & 1,335 & 4,055 & $-2,719$ & 17 & 52 & 17 \\
\hline 18 & 0,0601 & 5 & 0,4894 & 2 & 3,146 & 1,644 & 1,502 & 7 & 14 & 4 \\
\hline 19 & 0,0424 & 15 & 0,2712 & 17 & 1,487 & 3,418 & $-1,930$ & 14 & 46 & $14-15$ \\
\hline 20 & 0,0236 & 19 & 0,1338 & 20 & 0,249 & 5,272 & $-5,023$ & 20 & 59 & 20 \\
\hline
\end{tabular}

Atlikus skaičiavimus daugiatikslio sprendimo prièmimo metodais, buvo apskaičiuota ir ịvertinta PC ASA prioritetinè tvarka. Toliau pateikiami PC ASA plètros pasiūlymai urbanizuotose (daugiabučių namų) teritorijose. 


\subsubsection{Prekybos centrų automobilių stovėjimo aikšteliụ plètros pasiūlymai urbanizuotose (daugiabučių namų) teritorijose}

Daugiatiksliu vertinimo metodu SAW, TOPSIS, PROMETHEE taikymas parode, kad daugiabučiu namų teritorijose esančių PC ASA skirtingam apkrovimui daugiausiai įtakos turi ASV poreikis, užstatymo intensyvumas, butų ir dirbančiujjų gyventojų skaičius, PC ASA pasiekiamumas ir tiesioginis aikštelès matomumas iš daugiabučių namų butų.

„Urban Land“" institutas (JAV) pagal tarptautinę klasifikaciją PC skirsto į penkis tipus: PC pirkejui patogioje vietoje (angl. convenience), rajoninis supermarketas (angl. neighbourhood), apylinkès supermarketas, hipermarketas arba daugiafunkcinis PC (angl. community) ir regioninis hipermarketas (angl. regional). Mokslų daktaras Zagorskas (2007) savo disertacijoje išskiria trijų tipų PC pasiekiamumo požiūriu. Pirmasis tipas skirtas aptarnauti aplinkinius gyventojus, vyrauja kelionės pėsčiomis. Antrasis skirtas aptarnauti klientus, atvykstančius su LA ir trečiasis - mišrus. Tokie centrai statomi gyventojų koncentracijos vietose arba prie didžiausių magistralių ir kitų keleivinio transporto mazgų. JAV PC, skirti aptarnauti LA srautą pastaruoju metu yra ypač kritikuojami - teigiama, jog jų atsiradimas sukelia pagrindines aplinkos darnumo ir susisiekimo problemas. Anglijoje PC leidžiama statyti tik jų dydį apskaičiavus pagal gyventojų skaičių tam tikru atstumu. PC dydis visada turètų būti parenkamas pagal potencialų aptarnaujamų klientų skaičių, kuris apskaičiuojamas atsižvelgiant ị esamą situaciją, kad nebūtų sukurti papildomi LA srautai. PC dydis priklauso ir nuo jo vaidmens miesto aptarnavimo objektų tinkle, tai yra nuo to, ar jis yra vietinès, rajoninès, bendra miestinès ar net regioninès reikšmès.

Remiantis užsienio patirtimi ir atlikus kompleksinę atliktų tyrimų rezultatų analizę, šiame darbe buvo išskirtos keturios PC grupès pagal ASA užpildymą. Taip pat buvo nustatyti pagrindiniai kriterijai, kuriais remiantis tikslinga planuoti PC plètrą urbanizuotose teritorijose.

I grupè - nedideli PC (3.3 pav.), turintys iki 100 ASV. Šie PC įrengti gyvenamuosiuose rajonuose, daugiabučių namų teritorijose, kuriose vyrauja didesnis nei 1,00 užstatymo intensyvumas. PC aplinkinèje teritorijoje, 300 metrų spinduliu nuo PC ASA, ASV poreikis vidutiniškai siekia $363 \%$, teritorijoje gyvenančių darbingo amžiaus žmonių vidurkis - 2022, vidutiniškas butų skaičius - 1795. Tyrimo metu nustatytas pasiekiamumas pėsčiomis nuo PC ASA iki gyvenamojo būsto siekia nuo 3 iki 5 minučių.

Siekiant sumažinti kelionės trukmę, pasiekti inžinerinės infrastruktūros ir teritorinès plètros optimizaciją, šiuos PC tikslinga ịrengti daugiabučiu namų teritorijose. Tačiau jie turi atitikti ekspertu nustatytas tris pagrindines kriterijų ribines vertes (3.10 lentelè): užstatymo intensyvumas turi būti didesnis už 1,00, dirbančiųjų gyventojų skaičius turi būti daugiau kaip 2000 ir butų skaičius - virš 
1800. Pasiekiamumas pėsčiomis nuo PC ASA iki daugiabučių namų turi siekti iki 5 minučių ir jų negali skirti nedidesnė kaip D kategorijos gatvė (3.3 pav.).
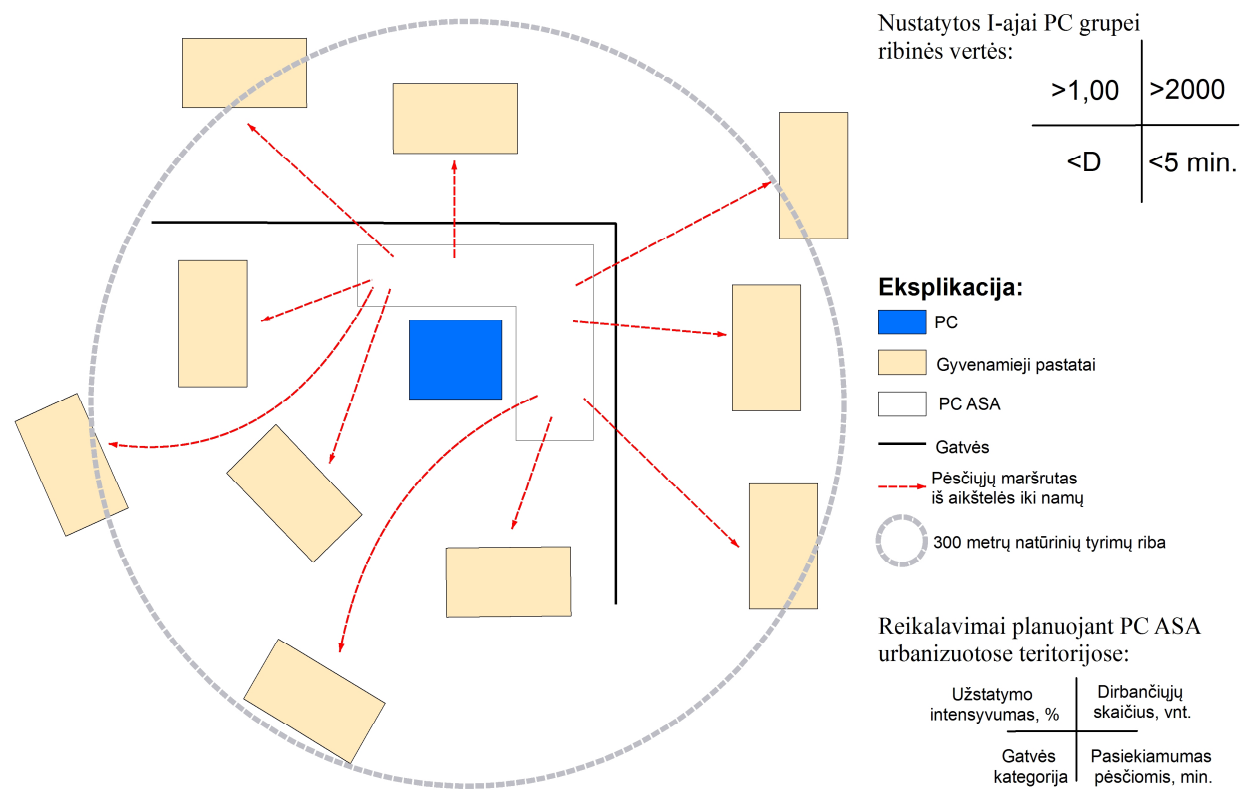

3.3 pav. I-osios grupés prekybos centrų automobilių stovejjimo aikštelių plètros schema (sudaryta autoriaus)

Fig. 3.3. The development scheme of car parking's of the shopping centres of group I (author's)

Tyrimais nustatyta ir praktiniais skaičiavimais pagrịsta, kad šie PC 5,6 \% leidžia sumažinti ASV skaičių nuo kiekvieno buto. Pavyzdžiui, įrengiant 100 ASA, bus sutaupoma 0,2 ha teritorijos ploto ir $1,5 \mathrm{mln}$. Lt.

II grupe - PC (3.4 pav.), turintys nuo 100 iki 150 LA stovejjimo vietų. PC aplinkinèje teritorijoje ASV poreikis vidutiniškai siekia $374 \%$, užstatymo intensyvumas - nuo 0,7 iki 1,00 , teritorijoje gyvenančių darbingo amžiaus žmonių vidurkis - 1610, butų skaičius - 1428. Tyrimo metu nustatytas pasiekiamumas pėsčiomis nuo PC ASA iki gyvenamojo būsto siekia nuo 5 iki 7 minučių (3.4 pav.).

Šios ASA užima $2000 \mathrm{~m}^{2}-3000 \mathrm{~m}^{2}$ ploto, todèl turi būti rastas santykis tarp kompaktiškos darniosios plètros, gyvenamojo rajono formos ir struktūros elementų išdėstymo teritorijoje. Skaičiavimais nustatyta, kad prie tokių ribinių verčių (3.10 lentelè), šių PC ASA leidžia sumažinti iki 5 \% ASV vienam butui.

III grupè - PC (3.5 pav.), turintys nuo 151 iki 200 LA stovejjimo vietų. PC aplinkinejje teritorijoje ASV poreikis vidutiniškai siekia $317 \%$, užstatymo 
intensyvumas - nuo 0,3 iki 0,7 , teritorijoje gyvenančių darbingo amžiaus žmonių vidurkis - 1160, vidutiniškai butų skaičius - 1090 .

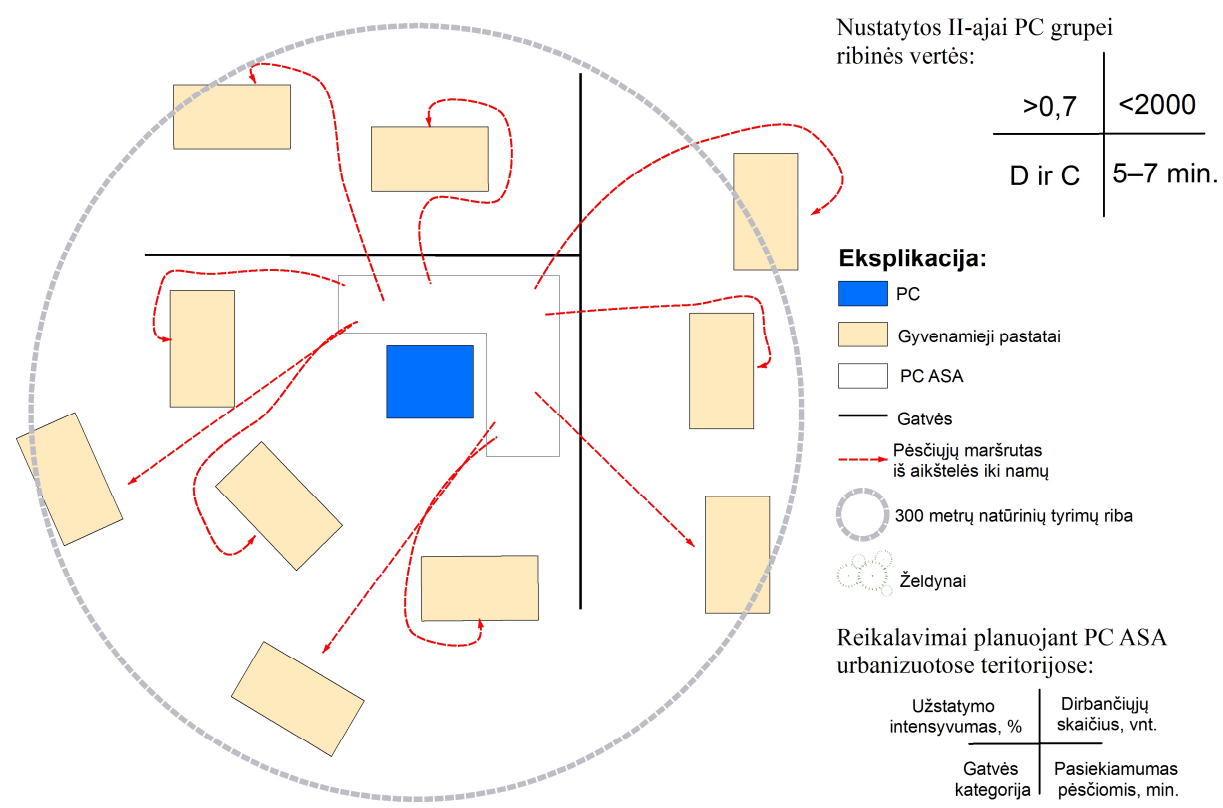

3.4 pav. II-osios grupès prekybos centrų automobilių stovèjimo aikštelių plètros schema (sudaryta autoriaus)

Fig. 3.4. The development scheme of car parking's of the shopping centres of group II (author's)

III-osios grupès PC yra išsidèstę prie pagrindinių miesto transporto koridorių (tai yra B ir C kategorijos gatvių), todèl, atliekant pasiekiamumo pėsčiomis tyrimą, nustatyta, kad gyventojas, palikęs LA stovèti PC ASA, grižti ị namus užtrunka nuo 7 iki 10 minučių. Šios ASA užima $3000 \mathrm{~m}^{2}-4000 \mathrm{~m}^{2}$ ploto, todèl dèl savo dydžio nerekomenduojama jų įrengti daugiabučių namų gyvenamuosiuose rajonuose. Blogas šių PC pasiekiamumas pėsčiomis, dažniausiai juos skiria greito eismo gatvès, todèl TP vairuotojas gaišta laiką kirsdamas gatvę. Dèl išvardintų aplinkybių tikslinga šios grupès PC ịrengti mišraus užstatymo teritorijoje, nes yra užtikrintas geras pasiekiamumas LA, didelè prekių ir paslaugu ịvairovè, nemokamas AS. Šias aikšteles tikslinga panaudoti SV sistemai. Dienos metu šiomis aikštelemis naudosis šioje teritorijoje dirbantys gyventojai ir ị miesto centrą vykstantys LA vairuotojai. 


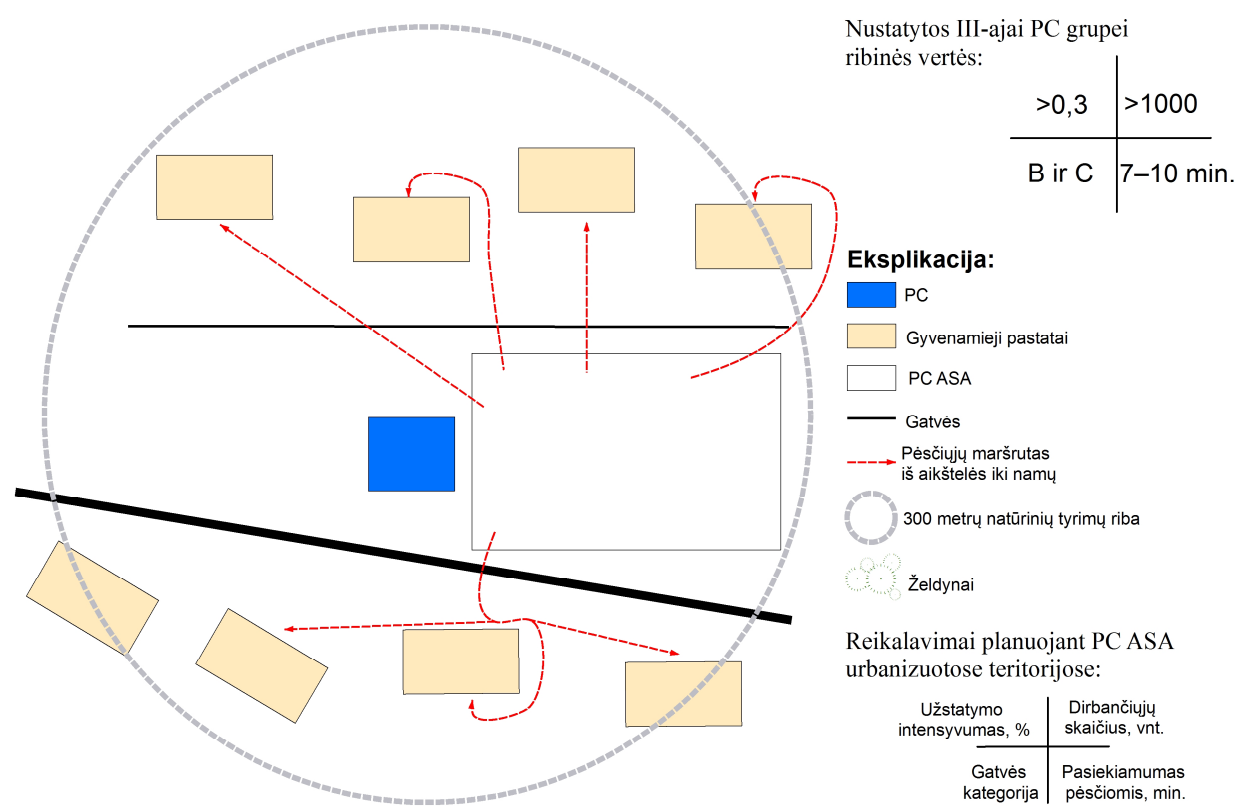

3.5 pav. III-osios grupès prekybos centrų automobilių stovèjimo aikštelių plètros schema (sudaryta autoriaus)

Fig. 3.5. The development scheme of car parking's of the shopping centres of group III (author's)

IV grupe - tai didžiausi PC, turintys virš 200 ASV, kurios užima daugiau kaip $4000 \mathrm{~m}^{2}$ plotą. PC aplinkinèje teritorijoje ASV poreikis vidutiniškai siekia $411 \%$, užstatymo intensyvumas iki 0,3 , teritorijoje gyvenančių darbingo amžiaus žmonių vidurkis - 950, vidutiniškas butų skaičius - 776 .

Šiems PC būdingos verslo, pramogų ir specifinių paslaugų funkcijos, orientuotos ị turtingus ir vidurinès klasès žmones. Jų lokalizacija demonstruoja savo išskirtinumą: didelès ASA (3.6 pav.), 2-4 eismo juostų ir generuotų srautų koncentracija, aukštas VT išvystymo lygis ir kita. Nors daugiabučiai namai ar jų grupès patenka ì 300 metrų analizuojamą spindulį, tačiau retas gyventojas naudojasi šia aikštele. Atliekant pasiekiamumo pésčiomis tyrimą nustatyta, kad gyventojas, palikęs LA ASA, grįžti užtruks mažiausiai 10 minučių. Rekomenduojama šiuos PC statyti priemiestinèse miesto teritorijose ir pritaikyti kombinuotų kelionių sistemoms diegti, pavyzdžiui, SV ar „Palik dvirati ir važiuok viešuoju transport" (angl. Bike and ride). 

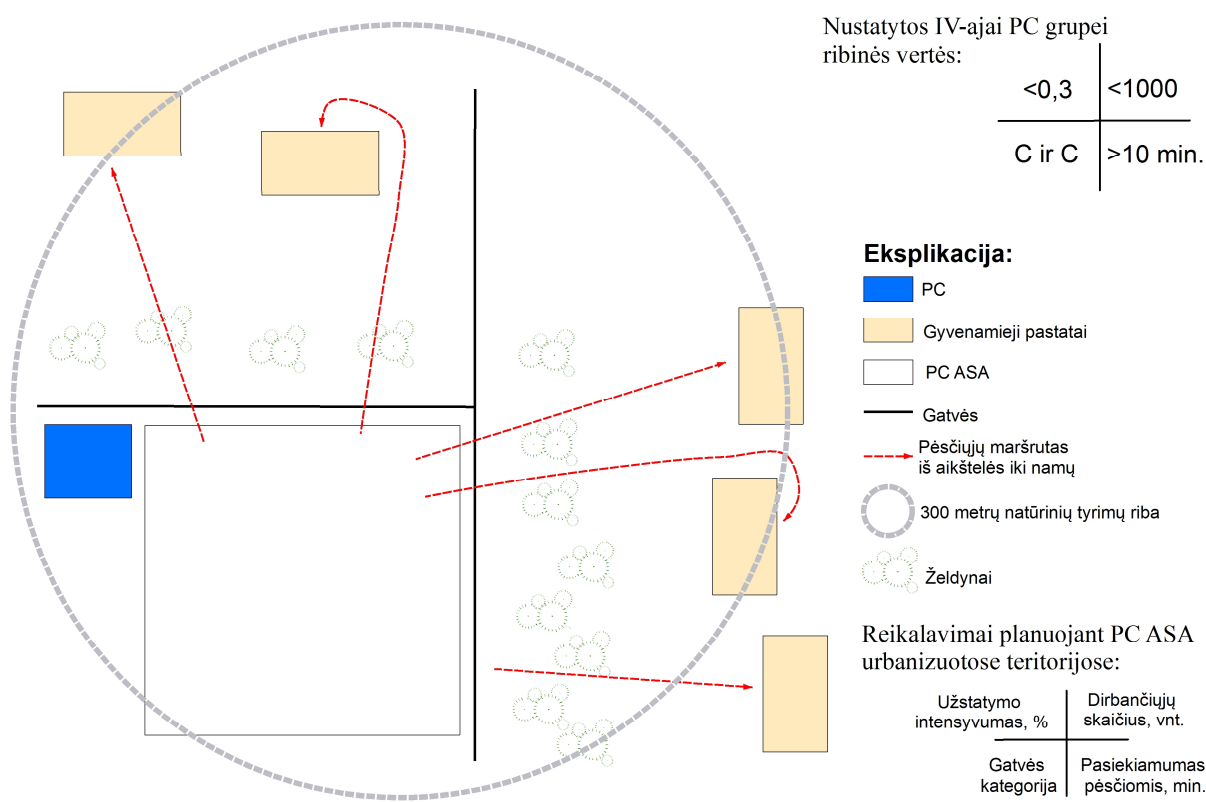

Reikalavimai planuojant PC ASA urbanizuotose teritorijose:

\begin{tabular}{r|l}
$\begin{array}{c}\text { Užstatymo } \\
\text { intensyvumas, \% }\end{array}$ & $\begin{array}{l}\text { Dirbančiuju } \\
\text { skaičius, vnt. }\end{array}$ \\
\hline $\begin{array}{c}\text { Gatvès } \\
\text { kategorija }\end{array}$ & $\begin{array}{l}\text { Pasiekiamumas } \\
\text { pesčiomis, min. }\end{array}$
\end{tabular}

3.6 pav. IV-osios grupės prekybos centrų automobilių stovèjimo aikštelių plètros schema (sudaryta autoriaus)

Fig. 3.6. The development scheme of car parking's of the shopping centres of group IV (author's)

Naujai planuojantiems PC ir jų ASA nustatytos ribinès vertės (3.10 lentelè). Jos nustatytos, remiantis analize, atlikta naudojant daugiatikslio vertinimo metodus. PC ASA plètra reglamentuota keturiais galimais ASV poreikio mažinimo būdais. $P C_{p}-\mathrm{PC}$ plotas $\left(\mathrm{m}^{2}\right), P C_{v}-\mathrm{PC}$ ASA vietų skaičius, $U I-$ užstatymo intensyvumas, $D G_{s}$ - dirbančiujų gyventojų skaičius, $B_{s}-$ butų skaičius, $P C_{k}-$ ASA užpildymo koeficientas pagal atliktus tyrimus, $P C_{r}-$ siūlomas ASV mažinimo procentas vienam butui.

3.10 lentelè. Siūlomos automobilių stovèjimo aikštelių mažinimo ribinès vertès Table 3.10. Suggested tresholds of car parking lots reduction

\begin{tabular}{ccccccc}
\hline$P_{p}$, & \multirow{2}{*}{$P C_{v}$} & \multicolumn{3}{c}{ Ribinès vertès } & \multirow{2}{*}{$P C_{k}$} & $P C_{r}$, \\
\cline { 3 - 6 } $\mathrm{m}^{2}$ & & $U I$ & $D G_{s}$ & $B_{s}$ & & $\%$ \\
\hline iki 2000 & iki 100 & $>1,00$ & $>2000$ & $>1800$ & 1,00 & 5,6 \\
\hline $2001-3000$ & $101-150$ & $0,7-1,00$ & $1500-1999$ & $1300-1799$ & 0,60 & 5,0 \\
\hline $3001-4000$ & $151-200$ & $0,3-0,7$ & $1200-1499$ & $1000-1299$ & 0,40 & - \\
\hline$>4001$ & $>201$ & $<0,3$ & $1000-1199$ & $800-999$ & 0,12 & - \\
\hline
\end{tabular}




\subsection{Statyk ir važiuok automobilių stovėjimo aikštelių vietos parinkimo atranka}

SV sistema yra originali viešoji keleivių susisiekimo sistema, veikianti kaip tradicinio VT papildinys. Ši sistema plačiai populiareja Europos miestuose. Jos esmę sudaro tai, kad LA paliekamas specialioje ASA miesto prieigose ir tolesnè kelionė tęsiama VT arba specialiu autobusu. SV sistema orientuota i miesto centro apkrovos LA mažinimą, ji padeda sumažinti TP keliamą triukšmą, oro ir vizualinę taršą mieste, taupo keleivių laiką ir pinigus.

2014-2020 m. ES struktūrinès paramos periodu numatytas finansavimas, skirtas SV sistemos ASA plètrai penkiuose didžiausiuose Lietuvos miestuose (Vilniuje, Kaune, Klaipėdoje, Šiauliuose ir Panevėžyje). Remiantis Vilniaus miesto BP sprendiniais, kuriuose nurodytos 33 SV sistemos aikštelių statybos vietos, planuojamos SV sistemos ASA suskirstomos į tris grupes, pagal miesto zonas (Burinskienè et al. 2014).

I-ają grupę sudaro $14 \mathrm{SV}$ sistemos ASA, kurias numatoma įrengti Vilniaus miesto priemiestinèje zonoje (3.11 lentelè).

3.11 lentelè. Statyk ir važiuok sistemos automobilių stovèjimo aikštelių Vilniaus miesto priemiestinejje zonoje

Table 3.11. Park and ride system's car parking's in suburban zone of Vilnius city

\begin{tabular}{|c|c|c|}
\hline $\begin{array}{c}\text { Aikštelès } \\
\text { Nr. }\end{array}$ & Aikštelès pavadinimas & Aikštelès adresas \\
\hline 1. & Oro uostas & A. Gustaičio g. 1 \\
\hline 2. & Senoji Plytinè & Saulètekio al. 32 \\
\hline 3. & Antakalnio VT žiedas & Antakalnio g. 130 \\
\hline 4. & Santariškès & Santariškių g. 1 \\
\hline 5. & Pilaitès pr. & Pilaitès pr. 31 \\
\hline 6. & Senasis Pilaitès kelias & Pilaitès pr. 13 \\
\hline 7. & Vaduvos VT žiedas & Vaduvos g. 3 \\
\hline 8. & PC Gariūnai & Gariūnų g. 70 \\
\hline 9. & Grigiškès & Kovo 11-osios 65, Grigiškès \\
\hline 10. & PC Maxima bazè & Savanorių pr. 247 \\
\hline 11. & PC Liepkalnio Maxima & Liepkalnio g. 112 \\
\hline 12. & St. Batoro g. sankryža & S. Batoro g. 92 \\
\hline 13. & Balsiai & Riešès g. 1 \\
\hline 14. & Riešès PC Iki & Molètų g. 13, Didžioji Riešè \\
\hline
\end{tabular}


II-ają grupę sudaro $13 \mathrm{SV}$ sistemos ASA, kurias numatoma irengti vidurineje miesto zonoje (3.12 lentelè).

3.12 lentelė. Statyk ir važiuok sistemos automobilių stovëjimo aikštelių Vilniaus miesto vidurinëje zonoje

Table 3.12. Park and ride system's car parking's in middle zone of Vilnius city

\begin{tabular}{cll}
\hline $\begin{array}{c}\text { Aikštelès } \\
\text { Nr. }\end{array}$ & \multicolumn{1}{c}{ Aikštelès pavadinimas } & \multicolumn{1}{c}{ Aikštelès adresas } \\
\hline 15. & Siemens arena & Ozo g. 14 \\
\hline 16. & Fabijoniškių VT žiedas & Ateities g. 91 \\
\hline 17. & Futbolo stadionas & Ozo g. 27 \\
\hline 18. & Spaudos rūmai & Laisvès pr. 60 \\
\hline 19. & Litexpo parodų rūmai & Parodų g.1 \\
\hline 20. & Naujasis Akropolis & Geležinio vilko g. 6 \\
\hline 21. & PC Mada & Viršuliškių g. 40 \\
\hline 22. & Šiaurès miestelio VT žiedas & Žirmūnų g. 137 \\
\hline 23. & Žirmūnų šilo tiltas & Žirmūnų g. 54D \\
\hline 24. & Jeruzalès PC Rimi & Jeruzalès g. 4 \\
\hline 25. & Justiniškių VT žiedas & Gabijos g. 30 \\
\hline 26. & PC BIG & Ukmergès g. 369 \\
\hline 27. & Ukmergès-Ozo g. sankryža & Ukmergès g. 198 A \\
\hline
\end{tabular}

III-ają grupę sudaro $6 \mathrm{SV}$ sistemos ASA, kurias numatoma ịrengti centrinëje miesto dalyje (3.13 lentelè).

3.13 lentelė. Statyk ir važiuok sistemos automobilių stovẻjimo aikštelių Vilniaus miesto centrinèje zonoje

Table 3.13. Park and ride system's car parking's in central zone of Vilnius city

\begin{tabular}{cll}
\hline $\begin{array}{c}\text { Aikštelès } \\
\text { Nr. }\end{array}$ & \multicolumn{1}{c}{ Aikštelès pavadinimas } & \multicolumn{1}{c}{ Aikštelès adresas } \\
\hline 28. & Stotis & Geležinkelio g. 16 \\
\hline 29. & Žvėryno VT žiedas & Sėlių g. 62 \\
\hline 30. & T. Kosciuškos g. ties Vilnele & T. Kosciuškos g. 1A \\
\hline 31. & PC Panorama & Saltoniškių g. 9 \\
\hline 32. & Kalvarijų turgavietė & Rinktinės g. 48B \\
\hline 33. & Kalvarijų ir Žalgirio g. sankryža & Kalvarijų g. 92 \\
\hline
\end{tabular}

Toliau taikomi daugiatikslio vertinimo metodai, kuriais nustatoma SV sistemos ASA parinkimo vietos. 


\subsubsection{Statyk ir važiuok sistemos daugiatikslis vertinimas, COPRAS, SAW ir TOPSIS metodais}

SV sistemos ASA daugiatiksliam vertinimui buvo atrinkti 11 kriterijų, kurių svoriai buvo nustatyti 2.2.6 skyriuje, 2.12 lenteleje. Nustatytiems kriterijams priskiriamos optimizavimo kryptys (minimizavimas arba maksimizavimas), svoriai, nurodomi matavimo vienetai ir suvedamos skaitinès reikšmès. Toliau taikomi daugiatiksliai sprendimo prièmimo metodai: COPRAS, SAW ir TOPSIS. Daugiatikslis vertinimas atliekamas naudojant 3.1.1 skyriuje pateiktas formules. COPRAS metodu skaičiavimai atliekami taikant (3.1)-(3.5) formules, skaičiavimai SAW metodu skaičiavimai atliekami taikant (3.6) ir (3.7) formules, o TOPSIS metodu (3.8)-(3.12) formules.

3.14 lentelè. Statyk ir važiuok sistemos automobilių stovèjimo aikštelių apskaičiuotos reikšmės daugiatikslio vertinimo metodais priemiestinëje miesto zonoje

Table 3.14 Park and ride system's car parking's calculated values by multipurpose assessment methods in peripheral zone of town

\begin{tabular}{|c|c|c|c|c|c|c|c|c|}
\hline \multirow{2}{*}{$\begin{array}{l}\text { Aikšt. } \\
\text { Nr. }\end{array}$} & \multicolumn{2}{|c|}{ SAW } & \multicolumn{2}{|c|}{ COPRAS } & \multicolumn{2}{|c|}{ TOPSIS } & \multirow{2}{*}{$\begin{array}{l}\text { Rangų } \\
\text { suma }\end{array}$} & \multirow{2}{*}{ Vieta } \\
\hline & $S_{j}$ & Vieta & $Z_{j}$ & Vieta & $C_{j}^{*}$ & Vieta & & \\
\hline 1. & 0,0822 & 3 & 0,0799 & 3 & 0,3992 & 6 & 12 & 3 \\
\hline 2. & 0,0714 & 9 & 0,0734 & 8 & 0,5838 & 2 & 19 & $6-9$ \\
\hline 3. & 0,0867 & 2 & 0,0887 & 1 & 0,6942 & 1 & 4 & 1 \\
\hline 4. & 0,0736 & 7 & 0,0755 & 7 & 0,5726 & 3 & 17 & 5 \\
\hline 5. & 0,0531 & 13 & 0,0550 & 13 & 0,1839 & 14 & 40 & $13-14$ \\
\hline 6. & 0,0573 & 12 & 0,0592 & 12 & 0,2147 & 13 & 37 & 12 \\
\hline 7. & 0,0756 & 6 & 0,0777 & 5 & 0,5230 & 4 & 15 & 4 \\
\hline 8. & 0,0809 & 4 & 0,0829 & 2 & 0,4042 & 5 & 11 & 2 \\
\hline 9. & 0,0640 & 10 & 0,0661 & 10 & 0,2986 & 10 & 30 & 10 \\
\hline 10. & 0,0725 & 8 & 0,0789 & 4 & 0,3784 & 7 & 19 & $6-9$ \\
\hline 11. & 0,0778 & 5 & 0,0756 & 6 & 0,3764 & 8 & 19 & $6-9$ \\
\hline 12. & 0,0595 & 11 & 0,0614 & 11 & 0,2581 & 11 & 33 & 11 \\
\hline 13. & 0,0520 & 14 & 0,0540 & 14 & 0,2377 & 12 & 40 & $13-14$ \\
\hline 14. & 0,0923 & 1 & 0,0709 & 9 & 0,3117 & 9 & 19 & $6-9$ \\
\hline
\end{tabular}

Atlikus SV sistemos ASA skaičiavimus priemiestinèje Vilniaus miesto zonoje (3.14 lentelè) nustatyta, kad iš 14 tiriamų ASA, potencialiausia vieta įrengti pirmają SV sistemos aikštelę - Antakalnio VT žiede (aikštelès Nr. 3). Pagrindinè priežastis, kuri nulèmé šios SV sistemos ASA aukščiausią vietą - 
gerai išvystytas VT, kurio dažnis siekia 64 maršrutus per valandą. Antroji pagal vietą - PC Gariūnai ASA (Nr. 8). Šios ASA aukštą vietą lèmė maža statybos kaina ir vidutinis VT greitis. Žemiausios vietos skirtos Pilaitės pr. (Nr. 5) ir Balsių mikrorajone (Nr. 13) esančioms PC ASA. Tai lèmė itin retas VT kursavimo dažnis ir didelè ASA įrengimo kaina.

3.15 lentelè. Statyk ir važiuok sistemos automobilių stovèjimo aikštelių apskaičiuotos reikšmės daugiatikslio vertinimo metodais vidurinejje miesto zonoje

Table 3.15 Park and ride system's car parking's calculated values by multipurpose assessment methods in middle zone of town

\begin{tabular}{|c|c|c|c|c|c|c|c|c|}
\hline \multirow{2}{*}{$\begin{array}{l}\text { Aikšt. } \\
\text { Nr. }\end{array}$} & \multicolumn{2}{|c|}{ SAW } & \multicolumn{2}{|c|}{ COPRAS } & \multicolumn{2}{|c|}{ TOPSIS } & \multirow{2}{*}{$\begin{array}{l}\text { Rangų } \\
\text { suma }\end{array}$} & \multirow[b]{2}{*}{ Vieta } \\
\hline & $S_{j}$ & Vieta & $Z_{j}$ & Vieta & $C_{j}^{*}$ & Vieta & & \\
\hline 15. & 0,0898 & 3 & 0,0855 & 3 & 0,4762 & 6 & 12 & $3-4$ \\
\hline 16. & 0,0688 & 10 & 0,0702 & 11 & 0,3333 & 12 & 33 & 11 \\
\hline 17. & 0,0824 & 5 & 0,0838 & 5 & 0,5429 & 3 & 13 & 5 \\
\hline 18. & 0,0812 & 6 & 0,0846 & 4 & 0,6218 & 1 & 11 & 2 \\
\hline 19. & 0,0752 & 7 & 0,0766 & 7 & 0,3906 & 9 & 23 & $8-9$ \\
\hline 20. & 0,0623 & 12 & 0,0635 & 12 & 0,2425 & 13 & 37 & $12-13$ \\
\hline 21. & 0,0923 & 1 & 0,0880 & 1 & 0,5448 & 2 & 4 & 1 \\
\hline 22. & 0,0609 & 13 & 0,0623 & 13 & 0,3381 & 11 & 37 & $12-13$ \\
\hline 23. & 0,0725 & 8 & 0,0738 & 8 & 0,5305 & 4 & 20 & 7 \\
\hline 24. & 0,0837 & 4 & 0,0794 & 6 & 0,4407 & 7 & 17 & 6 \\
\hline 25. & 0,0724 & 9 & 0,0732 & 9 & 0,4945 & 5 & 23 & $8-9$ \\
\hline 26. & 0,0672 & 11 & 0,0720 & 10 & 0,3413 & 10 & 3 & 10 \\
\hline 27. & 0,0904 & 2 & 0,0861 & 2 & 0,4121 & 8 & 12 & $3-4$ \\
\hline
\end{tabular}

Atlikus SV sistemos ASA skaičiavimus vidurineje miesto zonoje (3.15 lentelè), nustatyta, kad iš 13 tiriamų aikštelių, potencialiausia ịrengimui aikštelè yra prie PC „Mada“ (Nr. 21). Didžiausią įtaką skaičiavimo rezultatams turèjo VT kursavimo dažnis (39 maršrutai per valandą) ir SV sistemos ASA statybos kaina (16 tūkst. Lt). Antroji pagal užimtą vietą SV sistemos ASA vieta - prie Spaudos rūmų (Nr. 18). Jos aukštą vietą lėmè didelis maršrutų skaičius, kuris piko valandą siekia 63. Žemiausios vietos skirtos prie Naujojo Akropolio (Nr. 20) ir Šiaurès miestelio VT žiede (Nr. 22) esančioms aikštelëms. Pagrindinė priežastis - mažas VT greitis (atitinkamai $19,64 \mathrm{~km} / \mathrm{h}$ ir $16,04 \mathrm{~km} / \mathrm{h}$ ) ir didele statybų kaina (atitinkamai 261 tūkst. Lt ir 254 tūkst. Lt).

Atlikus III-osios grupès skaičiavimus, nustatyta, kad iš 6 aikštelių (3.16 lentelè) trys potencialiausios SV sistemos ASA ịrengimo vietos yra prie 
geležinkelio ir autobusų stoties (Nr. 28), prie PC „Panorama“ (Nr. 31) ir prie Kalvarijų turgavietès (Nr. 32). Žemiausios vietos skirtos T. Kosciuškos gatvèje ties Vilnele (Nr. 30) ir Žvèryno VT žiede (Nr. 29) esančioms aikštelëms. Tai lèmè mažiausias šioje zonoje VT kursavimo dažnis ir didelè SV sistemos ASA statybos kaina.

3.16 lentelè. Statyk ir važiuok sistemos automobilių stovèjimo aikštelių apskaičiuotos reikšmès daugiatikslio vertinimo metodais centrinëje miesto zonoje

Table 3.16 Park and ride system's car parking's calculated values by multipurpose assessment methods in central zone of town

\begin{tabular}{ccccccccc}
\hline $\begin{array}{c}\text { Aikšt. } \\
\text { Nr. }\end{array}$ & \multicolumn{2}{c}{ SAW } & \multicolumn{2}{c}{ COPRAS } & \multicolumn{2}{c}{ TOPSIS } & Rangu \\
& $S_{j}$ & Vieta & $Z_{j}$ & Vieta & $C_{j}^{*}$ & Vieta & Vieta \\
suma & \\
\hline 28. & 0,1831 & 3 & 0,1822 & 2 & 0,6231 & 1 & 6 & $1-3$ \\
\hline 29. & 0,1367 & 6 & 0,1372 & 6 & 0,3056 & 6 & 18 & 6 \\
\hline 30. & 0,1489 & 5 & 0,1562 & 4 & 0,3675 & 5 & 14 & 5 \\
\hline 31. & 0,1845 & 2 & 0,1918 & 1 & 0,4445 & 3 & 6 & $1-3$ \\
\hline 32. & 0,1943 & 1 & 0,1783 & 3 & 0,4719 & 2 & 6 & $1-3$ \\
\hline 33. & 0,1515 & 4 & 0,1533 & 5 & 0,4038 & 4 & 13 & 4 \\
\hline
\end{tabular}

Daugiatikslio vertinimo metodais gauti rezultatai perkelti ị GIS ir sukurta SV sistemos ASA planavimo bazè.

\subsubsection{Statyk ir važiuok automobilių stovèjimo aikšteliụ GIS planavimo bazè}

SV sistemos ASA planavimo bazè - tai GIS dalis, sudaryta iš grafinių ir tekstinių duomenų, reikalingų siekiant analizuoti ir vertinti planuojamą teritorijos vietą, prognozuoti jos raidą, pagrịsti priimtą sprendimą.

Norint sukurti SV sistemos ASA planavimo bazę, pirmiausia reikia sukurti informacinę bazę. Ji gali būti labai ịvairi: didelès, vidutinès ir mažos apimties. Informacinè bazè - tai kiekybinių ir kokybinių teritoriškai orientuotų duomenų visuma, kurios apimtis priklauso nuo pačio kūrèjo. Ji gali būti papildyta, tai yra sumažinta arba padidinta, atsižvelgiant i planuojamos teritorijos raidos procesus ar poreikius. Šiuo atveju, kiekybinių ir kokybinių duomenų visuma apskaičiuota naudojant daugiatikslius vertinimo metodus. Kiekvienam planavimo atvejui informacinè bazè turi būti tik tokia, kokia reikalinga. Todèl bazès duomenys turi atitikti tris savybes (Juškevičius 2003):

1. Tikslą, tai yra informacija renkama numatytam tikslui pasiekti. 
2. Vertę - tai socialinis, ekonominis, aplinkosauginis ar kitoks efektas, kurị galima gauti tinkamai panaudojus informaciją. Todèl ji turi būti patikima, reprezentatyvi, gaunama laiku, o informacijos vartotojas kompetentingas tinkamai ją naudoti.

3. Patikimumą ir reprezentatyvumą - surinkta informacija yra teisinga ir iš tiesų atspindi tikrają padètị (reiškinị, procesą).

\subsubsection{Statyk ir važiuok automobiliụ stovèjimo aikšteliụ sisteminè atranka}

SV sistemos ASA funkcionavimo sėkmè priklauso nuo SS integracijos į miestų planavimo procesą, kurio metu išsprendžiami žemès nuosavybės klausimai, nustatomas finansinių išteklių ir susisiekimo poreikis, ịvertinamos ASA įrengimo galimybès ir kita, buvo pasiūlyta SV sistemos ASA sisteminè atrankos strategija, kuriai igyvendinti sudarytas linijinio traukos centro (toliau - LTC) kokybès indekso $\left(K_{j}\right)$ skaičiavimo matematinis modelis (3.7 pav.).

3.17 lentelè. Linijiniam traukos centrui priskirtos statyk ir važiuok sistemos automobilių stovejjimo aikštelès

Table 3.17 Car parking's of park and ride system assigned to linear attraction center

\begin{tabular}{ccccc}
\hline $\begin{array}{c}\text { Eil. } \\
\text { Nr. }\end{array}$ & $\begin{array}{c}\text { LTC } \\
\text { pavadinimas }\end{array}$ & $\begin{array}{c}\text { ASA skaičius } \\
\text { priemiestineje } \\
\text { zonoje }\end{array}$ & $\begin{array}{c}\text { ASA skaičius } \\
\text { vidurineje zonoje }\end{array}$ & $\begin{array}{c}\text { ASA skaičius } \\
\text { centrinëje zonoje }\end{array}$ \\
\hline 1. & $\mathrm{~A} 1$ & 4 & 2 & 0 \\
\hline 2. & 5212 & 2 & 2 & 2 \\
\hline 3. & $\mathrm{~A} 2$ & 0 & 5 & 0 \\
\hline 4. & $\mathrm{~A} 14$ & 3 & 3 & 2 \\
\hline 5. & 102 & 2 & 1 & 0 \\
\hline 6. & 103 & 1 & 0 & 1 \\
\hline 7. & $\mathrm{~A} 3$ & 1 & 0 & 0 \\
\hline 8. & Oro uostas & 1 & 0 & 1 \\
\hline
\end{tabular}

SV sistemos modeliui sudaryti buvo analizuojamas atstumas nuo ASA iki miesto centro. Miesto centro atskaitos tašku pasirinktas „Žaliasis tiltas“. Visos nagrinèjamos $33 \mathrm{SV}$ sistemos ASA suskirstytos į $8 \mathrm{LTC}$ (3.17 lentelè), iš kurių 4 LTC priskirti magistraliniams keliams (A1, A2, A3, A14), 2 rajoniniams keliams $(102,103), 1$ vietiniam keliui Nr. 5212 ir oro uostui. Kiekviename LTC esančiu SV sistemos ASA skaičius svyruoja nuo 1 iki 8. Modelyje yra vertinami ASA rangai, plotai, atstumas iki miesto centro ir LTC sankirtos. 
Vilniaus mieste SV sistemos ASA plotai nustatyti remiantis Šiaurès Floridos (JAV) apygardos transporto agentūros atliktais tyrimais bei parengta galimybių studija (2010), kurioje siūloma priemiestinèse miesto zonose įrengti didžiausias SV sistemos ASA, kurių plotas siektų iki $25495 \mathrm{~m}^{2}$, vidurinèje zonoje rekomenduojama ịrengti mažesnes ASA iki $10926 \mathrm{~m}^{2}$ ir centrinejje dalyje iki $3237 \mathrm{~m}^{2}$ ploto ASA.

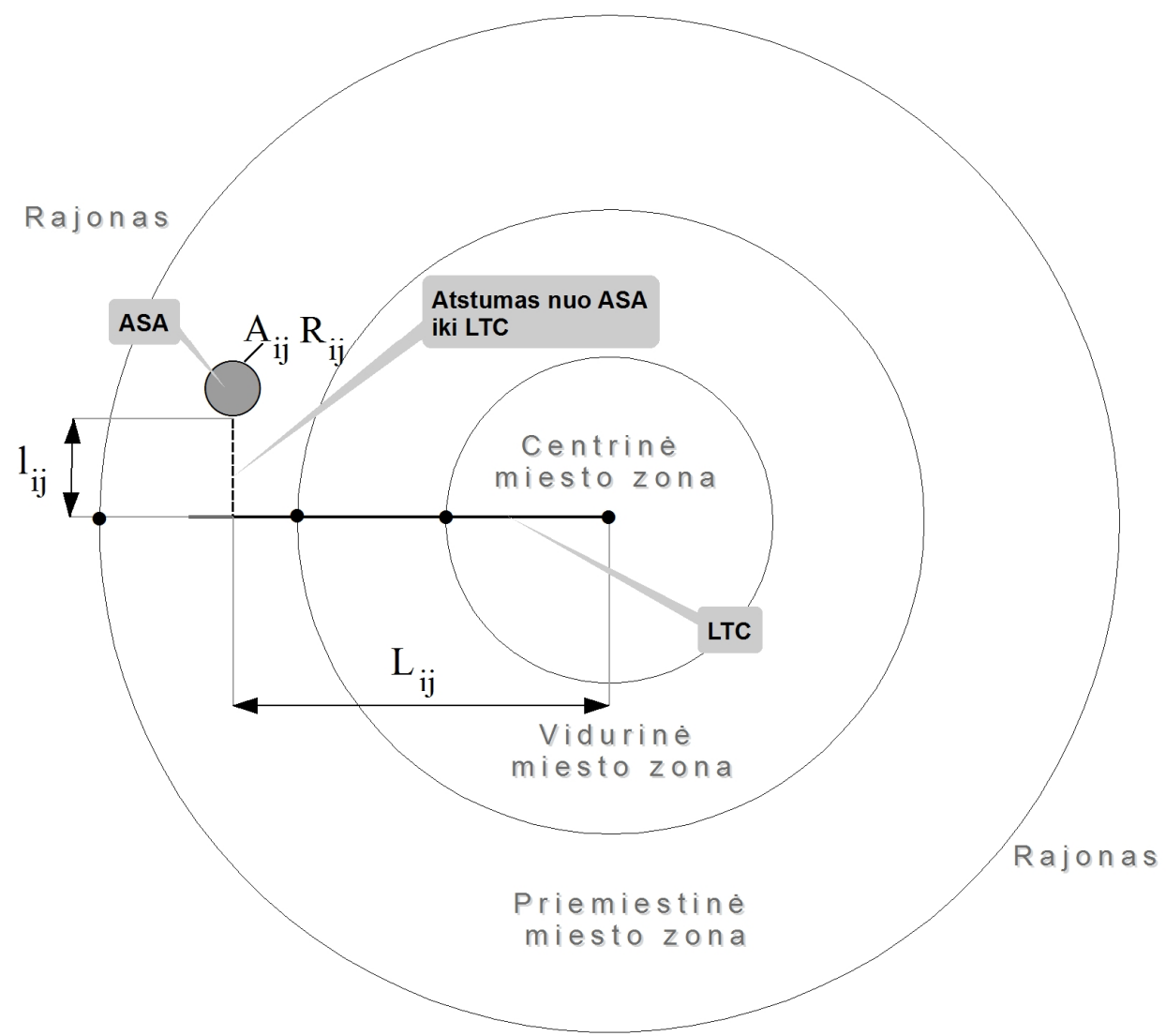

3.7 pav. Linijinio traukos centro kokybès indekso skaičiavimo matematinis modelis (sudaryta autoriaus)

Fig. 3.7. Mathematical model of quality index calculation of linear attraction center (author's)

SV sistemos ASA rangai nustatyti daugiatiksliais vertinimo metodais, kuriuos naudojant kiekvienai ASA (priemiestinejje, vidurinejje ir centrinejje) miesto zonoje buvo suteiktas rangas (3.8 pav.). 
Daugiausia SV sistemos ASA priskirta LTC (kelio Nr. A14), mažiausias skaičius (1 ASA) - oro uostui. Detalesnè informacija apie SV sistemos ASA, esančias LTC, pateikta 3.17 lentelëje ir 3.8 paveiksle.

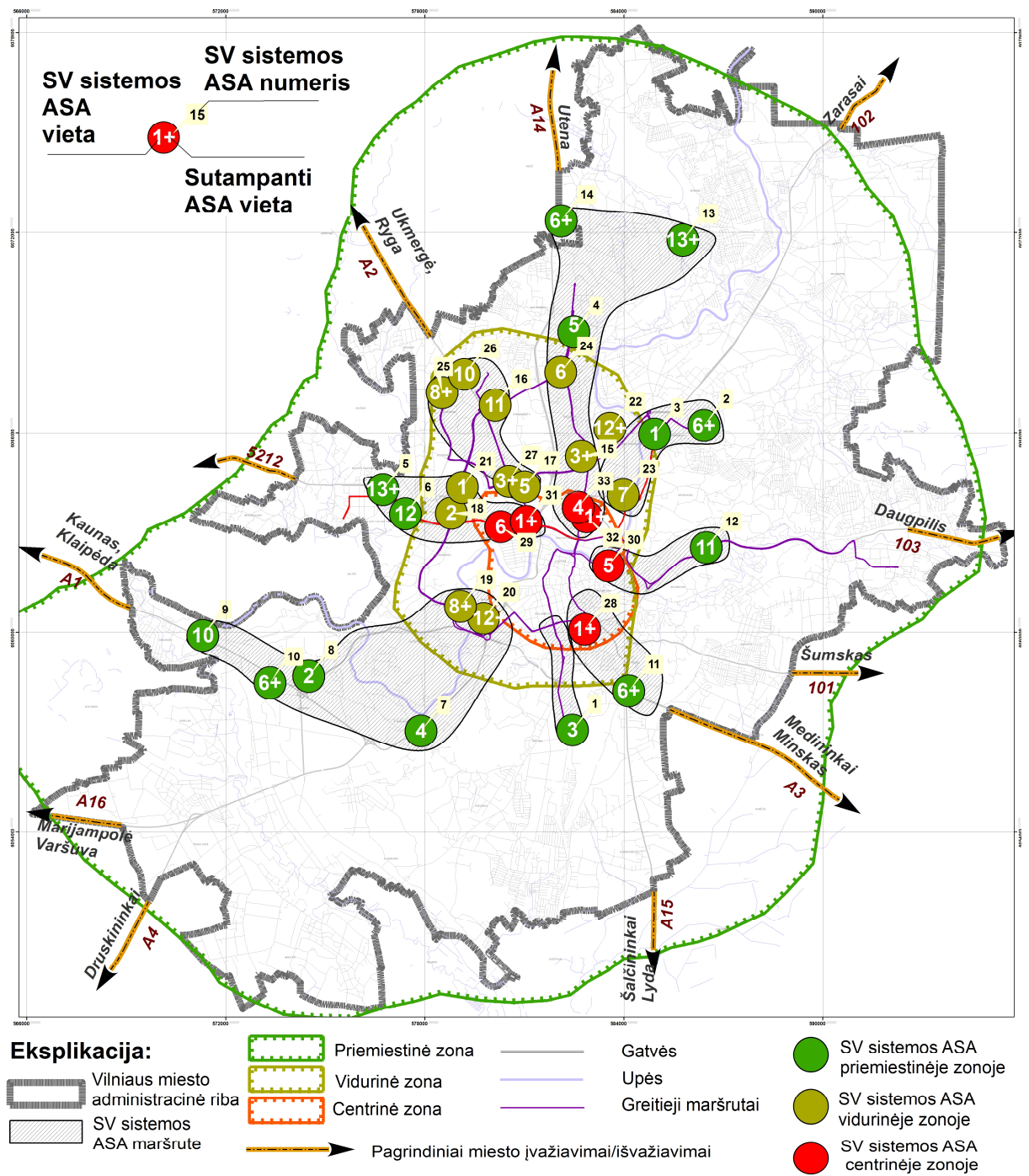

3.8 pav. Vilniaus mieste statyk ir važiuok sistemos automobilių stovejjimo aikštelių išdèstymo schema pagal prioritetų eilę

Fig. 3.8. System layout of park and ride system's car parking's in Vilnius city by priority queque 
Siekiant vienu skaičiumi ịvertinti LTC ir jo infrastruktūros kokybę ir tinkamumą SV sistemos ASA plètoti, kurie racionaliai tvarkyti ASA sistemą, cheminę aplinkos taršą, transporto priemonių grūstis, avarijų skaičių bei gerinti žmonių gyvenimo kokybę, pasiūlytas SV sistemos ASA kokybès indekso skaičiavimo matematinis modelis. Jis skaičiuojamas pagal autoriaus sudarytą formulę:

$$
K_{j}=\frac{\sum_{i=1}^{I} \frac{\left(L_{i j}-l_{i j}\right)^{2}}{A_{i j} \cdot R_{i j}}}{\frac{\sum_{j=1}^{J} I_{j}}{J} \cdot \sum_{j=1}^{J} \sum_{i=1}^{I} R_{i j}} .
$$

Čia $K_{j}$ - LTC kokybès indeksas, $J$ - LTC skaičius mieste $(j=1,2, \ldots, J) ; I$ ASA skaičius $j$-ame maršrute, tai yra LTC $(i=1,2, \ldots, I) ; K$ - ASA skaičius mieste, tai yra visuose LTC $(k=1,2, \ldots, K), K=\sum_{j=1}^{J} I_{j} ; R-$ ASA rangas, nustatytas ekspertų daugiatiksliais metodais (visų ASA rangų skaičius $K$, o visų ASA rangu suma $\left.R_{i j}=R_{1}+R_{2}+\ldots+R_{K}\right) ; R_{i j}-$ i-ojo LTC i-osios ASA rangas $(i=1,2 \ldots, I ; j=1,2, \ldots, J) ; A_{i j}$ - ASA plotas; $L_{i j}-$ j-ojo LTC i-ojo ruožo (magistralinès ịvažiavimo ị miestą gatvès) ilgis nuo ASA sankirtos su LTC iki miesto centro; $l_{i j}$-atstumas nuo ASA iki LTC.

Žemiau pateikiamas SV sistemos ASA kokybès indekso LTC skaičiavimo pavyzdys A3 maršrute, pagal (3.16) formulę:

$$
K_{j}=\frac{\frac{(4600-2000)^{2}}{25495 \cdot 6}}{\frac{33}{2} \cdot 561}+\frac{\frac{(2200-100)^{2}}{3237 \cdot 1}}{\frac{33}{2} \cdot 561}=0,15 .
$$

Atlikus visus skaičiavimus, pagal (3.16) formulę buvo suskaičiuoti ir praktiškai patikrinti racionaliausi SV sistemos ASA maršrutai Vilniaus mieste (3.18 lentelè).

Nustatyta, kad LTC kokybės indeksas svyruoja nuo 0 iki 1 . Kuo arčiau 1, tuo LTC maršrutas geresnis, kuo arčiau 0, tuo blogesnis. Nustatyta, kad A14 LTC maršrute kokybės rodiklis lygus 1,13 , tai reiškia, kad šiame maršrute yra 
per didelis kiekis SV sistemos ASA ir sistema yra persotinta. Tačiau, atmetus 2 ASA, kokybès indeksas - 0,94.

3.18 lentelè. Statyk ir važiuok sistemos automobilių stovėjimo aikštelių skaičiavimo rezultatai

Table 3.18 Results of calculation of park and ride system's car parking's data

\begin{tabular}{|c|c|c|c|c|c|c|c|}
\hline $\begin{array}{c}\text { LTC } \\
\text { pavadinimas }\end{array}$ & $\begin{array}{l}\text { ASA nr. } \\
\text { LTC }\end{array}$ & $\begin{array}{c}L_{i j}, \\
\mathrm{~m}\end{array}$ & $l_{i j}, \mathrm{~m}$ & $\begin{array}{c}\quad R_{i j}, \\
\text { rangas }\end{array}$ & $A_{i j}, \mathrm{~m}^{2}$ & $K_{j}$ & Vieta \\
\hline \multirow{6}{*}{ A1 } & 1 ASA & 13300 & 8300 & 10 & 25495 & \multirow{6}{*}{0,45} & \multirow{6}{*}{3} \\
\hline & 2 ASA & 11200 & 6200 & 6 & 25495 & & \\
\hline & 3 ASA & 9400 & 5000 & 2 & 25495 & & \\
\hline & 4 ASA & 7500 & 300 & 4 & 25495 & & \\
\hline & 5 ASA & 4100 & 300 & 8 & 10926 & & \\
\hline & 6 ASA & 3500 & 600 & 12 & 10926 & & \\
\hline \multirow{6}{*}{5212} & 1 ASA & 7100 & 300 & 13 & 25495 & \multirow{6}{*}{0,65} & \multirow{6}{*}{2} \\
\hline & 2 ASA & 6100 & 100 & 12 & 25495 & & \\
\hline & 3 ASA & 4800 & 500 & 2 & 25495 & & \\
\hline & 4 ASA & 6000 & 1200 & 1 & 25495 & & \\
\hline & 5 ASA & 3000 & 100 & 6 & 10926 & & \\
\hline & 6 ASA & 2100 & 100 & 1 & 10926 & & \\
\hline \multirow{5}{*}{ A2 } & $1 \mathrm{ASA}$ & 7300 & 700 & 10 & 10926 & \multirow{5}{*}{0,44} & \multirow{5}{*}{4} \\
\hline & 2 ASA & 7000 & 300 & 8 & 10926 & & \\
\hline & 3 ASA & 5700 & 500 & 11 & 10926 & & \\
\hline & 4 ASA & 3500 & 300 & 3 & 10926 & & \\
\hline & 5 ASA & 3400 & 300 & 5 & 10926 & & \\
\hline \multirow{8}{*}{ A14 } & $1 \mathrm{ASA}$ & $10 \quad 100$ & 2100 & 6 & 25495 & \multirow{8}{*}{$1,13^{*}$} & \multirow{8}{*}{1} \\
\hline & 2 ASA & 10500 & 4300 & 13 & 25495 & & \\
\hline & 3 ASA & 7000 & 100 & 5 & 25495 & & \\
\hline & 4 ASA & 6000 & 500 & 6 & 10926 & & \\
\hline & 5 ASA & 4700 & 500 & 3 & 10926 & & \\
\hline & 6 ASA & 4500 & 800 & 12 & 10926 & & \\
\hline & 7 ASA & 1400 & 100 & 4 & 3237 & & \\
\hline & 8 ASA & 1300 & 100 & 1 & 3237 & & \\
\hline \multirow{3}{*}{102} & 1 ASA & 6500 & 300 & 6 & 25495 & \multirow{3}{*}{0,28} & \multirow{3}{*}{5} \\
\hline & 2 ASA & 5900 & 100 & 1 & 25495 & & \\
\hline & 3 ASA & 3600 & 300 & 7 & 10926 & & \\
\hline \multirow{2}{*}{103} & $1 \mathrm{ASA}$ & 4600 & 100 & 11 & 25495 & \multirow{2}{*}{0,02} & \multirow{2}{*}{8} \\
\hline & 2 ASA & 1200 & 100 & 5 & 3237 & & \\
\hline \multirow{2}{*}{ A3 } & $1 \mathrm{ASA}$ & 4600 & 2000 & 6 & 25495 & \multirow{2}{*}{0,15} & \multirow{2}{*}{6} \\
\hline & 2 ASA & 2200 & 100 & 1 & 3237 & & \\
\hline Oro uostas & 1 ASA & 6500 & 100 & 3 & 25495 & 0,03 & 7 \\
\hline
\end{tabular}

*Pastaba. Jeigu kokybès indeksas yra virš 1, tai reiškia, kad SV sistema yra persotinta ASA, todèl galima atmesti iš LTC viena ASA. 
Gauti skaičiavimai rodo, kad I etapu SV sistemos ASA Vilniaus mieste turi būti diegiamos Kalvarijų gatvès LTC maršrute (3.20 lentelè). Ši maršrutą sudaro $8 \mathrm{SV}$ sistemos ASA. Kokybès indeksas, išeleminavus 2 ASA, yra 0,94.

II etapu SV sistemos ASA planuojamos kelio Nr. 5212 LTC maršrute, kuriame planuojamos $6 \mathrm{SV}$ sistemos ASA, $K_{j}=0,65$.

III etapu SV sistemos ASA planuojamos magistralinio kelio Nr. A1 LTC maršrute. Jame yra $6 \mathrm{SV}$ sistemos ASA. Svarbu paminèti, kad, įrengiant naują ASA, šalia Naujuoju Akropoliu, turi būti pertvarkyta VT stotelių sistema, $K_{j}=0,45$.

VI etapu SV sistemos ASA planuojamos magistralinio kelio Nr. A2 LTC maršrute. Jame yra $5 \mathrm{SV}$ sistemos ASA, $K_{j}=0,44$.

V etapu SV sistemos ASA planuojamos kelio Nr. 102 LTC maršrute. Maršrutą sudaro $3 \mathrm{SV}$ sistemos ASA, $K_{j}=0,28$.

VI etapu SV sistemos ASA planuojamos magistralinio kelio Nr. A3 LTC maršrute, kuriame yra 2 SV sistemos ASA. Pirmoji ASA aptarnaus priemiestinę miesto zoną ties PC „Maxima“ Liepkalnio gatvejje. Antroji aptarnaus centrinę miesto dali, ties geležinkelio ir autobusų stotimis, $K_{j}=0,15$.

VII etapu SV sistemos ASA planuojamos nuo Vilniaus miesto Oro uosto LTC maršrute. Jame veiks viena SV sistemos ASA, kuri įrengta šalia oro uosto, $K_{j}=0,03$.

VIII etapu SV sistemos ASA planuojamos kelio Nr. 103 LTC maršrute, kuriame numatomos $2 \mathrm{SV}$ sistemos ASA. Pirmoji planuojama priemiestinèje miesto zonoje ties St. Batoro g. sankryža, kita - centrinèje miesto zonoje - T. Kosciuškos gatvèje ties Vilnelès upeliu, $K_{j}=0,02$.

\subsubsection{Statyk ir važiuok automobilių stovèjimo aikštelių koncepciniai modeliai}

İrengiant SV sistemos ASA mieste, būtina atsižvelgti ị tai, kad jos gali būti naudojamos ne tik ilgam, bet ir laikinai atvykstantiems svečiams. Planuojant SV sistemos ASA vietų skaičių, labai svarbu iš anksto numatyti, kaip jos funkcionuos. SV sistemos ASA užpildymo koeficientas priklauso nuo atvykimo tikslo, paros laiko, sezono ir nuo vairuotojo finansinès padèties. Todèl projektuojant SV sistemos ASA reikia išanalizuoti apkrovos režimą laiko ir erdvès atžvilgiu. Kadangi tokios sistemos Lietuvos miestuose nèra, tai ASA turi būti projektuojamos remiantis užsienio miestų patirtimi. 
Viena didžiausių problemų, su kuria susiduriama prieš diegiant SV sistemą Vilniaus mieste, tai žemės paėmimas visuomenès poreikiams. Tokiu atveju yra nežinoma proceso trukmė ir ginčų, kurie iškyla tarp paimamos žemės savininkų ir žemès paėmimu suinteresuotos institucijos, nagrinëjimo galutinis rezultatas. Todèl, projektuojant Vilniaus mieste SV sistemos ASA, autorius sukūrẻ 3 ASA koncepcinius modelius, kurie pritaikyti realioje erdveje.

I koncepcinis modelis. Tai didžiausios SV sistemos ASA, kurias tikslinga irengti priemiestineje miesto zonoje. Šis koncepcinis modelis suprojektuotas šalia Antakalnio VT žiedo esančiame laisvame žemès sklype (3.9 pav.). ASA žemės plotas užima 13,0 ha, joje numatomas ASV skaičius yra 277, iš kurių 1 vieta skirta elektromobiliui su ikkrovimo stotele. Jeigu augantis elektromobilizacijos lygis pareikalaus daugiau stovejimo vietų, tai ESA numatyta iki 14 vietų plètrai, su ịkrovimo stotelemis. Papildomai SV sistemos ASA numatyta sustok ir išleisk ar paimk ir važiuok zona (angl. Kiss and ride), kur LA vairuotojas nuveža ar pasiima keleivị per trumpą laiką (pvz., iki 5 min.), tam skirtoje keleivio išlaipinimo ar ịlaipinimo zonoje.

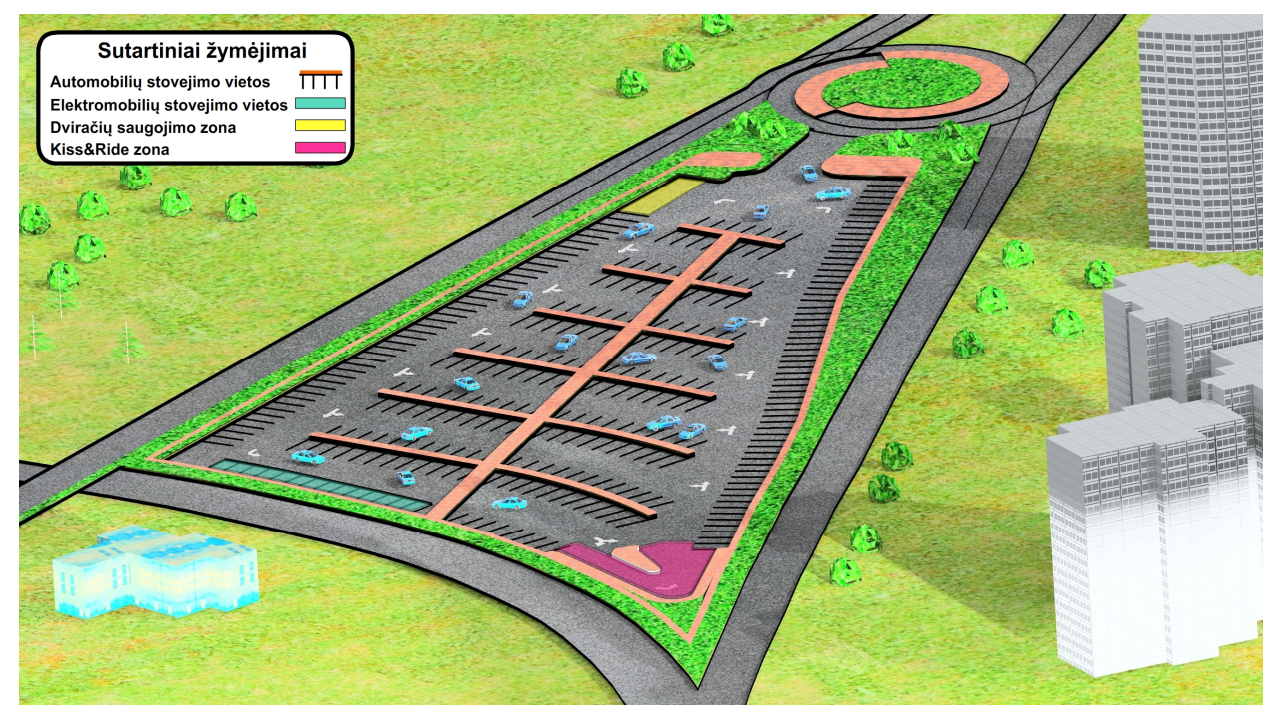

3.9 pav. Statyk ir važiuok sistemos automobilių stovejjimo aikštelių I koncepcinis modelis (sudaryta autoriaus)

Fig. 3.9. I conceptional model of park and ride system's car parking's (author's)

SV sistemos ASA numatyta nemotorizuoto TP stovejjimo zona, kurioje SV poreikis apskaičiuojamas pagal autoriaus sudaryta formulę:

$$
P_{1}=D_{e_{1}}+\left(D_{p}-D_{e}\right) \beta .
$$


Čia $P_{1}$ - vietų skaičius nemotorizuoto TP stovejjimo zonoje (vnt.), $D_{e}$ ir $D_{p}-$ esamas ir prognozuojamas dviračių skaičius piko valandą ties ASA (vnt.), $\beta$ skaičiuojamas dviračių skaičius pirmaisiais metais.

Ivažiavimas ị ASA numatytas šiaurinèje aikštelès dalyje, įrengiant „turbo“ žiedą. Iš ASV gyventojai saugiai pasieks VT stotelę.

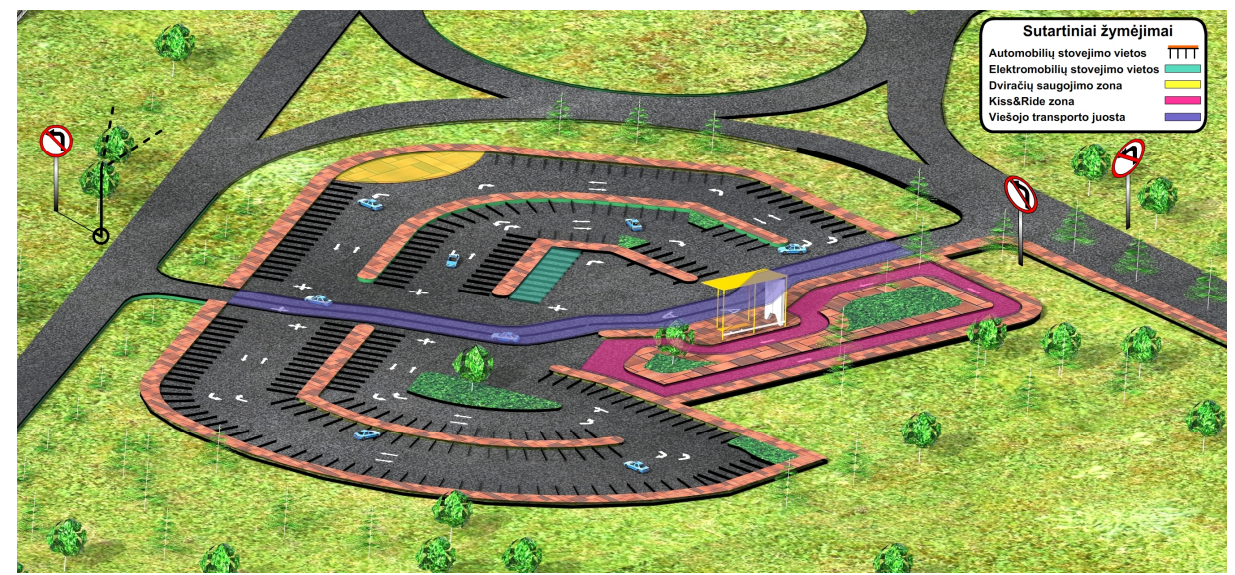

3.10 pav. Statyk ir važiuok sistemos automobilių stovējimo aikštelių II koncepcinis modelis (sudaryta autoriaus)

Fig. 3.10. II conceptional model of park and ride system's car parking's (author's)

II koncepcinis modelis. Tai mažesnès SV sistemos ASA, kurios galètų talpinti nuo 101 iki 250 ASV. Jas tikslinga ịrengti priemiestinëje ir vidurinejje miesto zonoje. Šis koncepcinis modelis suprojektuotas šalia Santariškių žiedinès sankryžos (3.10 pav.). ASA žemès plotas užima 12,5 ha, joje numatomas ASV skaičius yra 233, iš kurių 1 vieta skirta elektromobiliui su ịkrovimo stotele. Ši ASA ypatinga tuo, kad joje įrengta VT stotelè ir keleivių išlaipinimo zona, kurioje keleivis bus saugiai išlaipintas ir netrukdomai pasieks VT stotelę.

III koncepcinis modelis. Tai mažo dydžio SV sistemos ASA, kurias tikslinga ịrengti vidurinejje ar centrinejje miesto zonoje. Jeigu nèra galimybès priemiestinejje miesto zonoje paimti visuomenès poreikiams reikiamo dydžio žemès sklypo ASA irrengti, gali būti taikoma išimtis. Tačiau šioje zonoje projektuojant ASA turi būti užtikrintas ASV poreikis, kuri galima pasiekti statant požemines, daugiaaukštes ar montuojant laikinujų konstrukcijų ASA. 


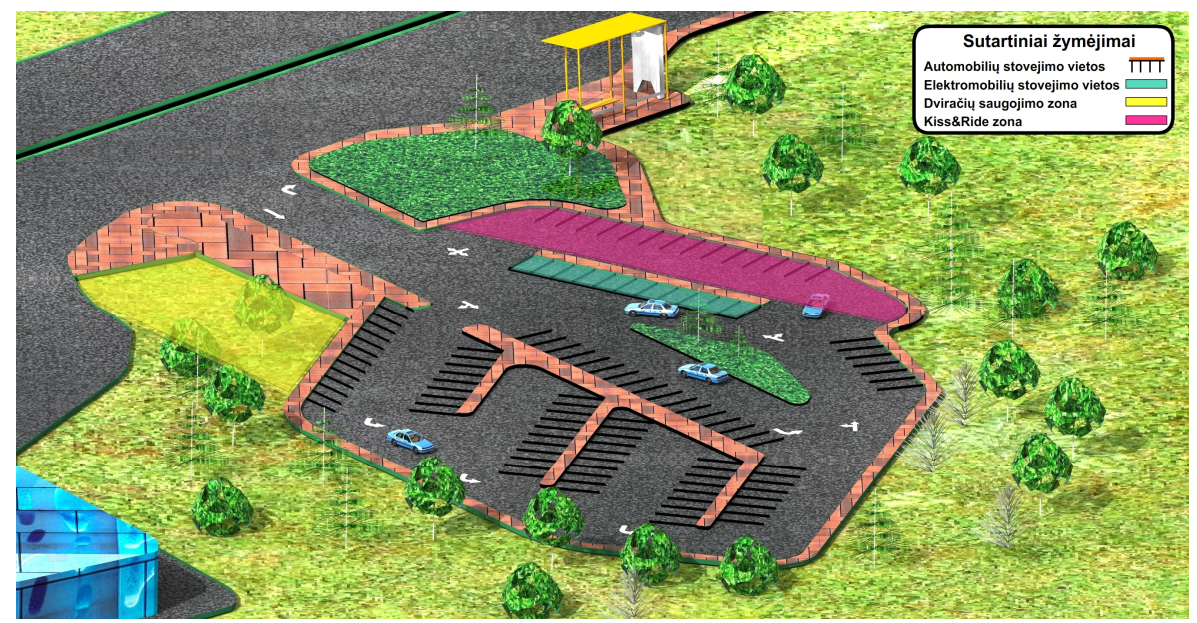

3.11 pav. Statyk ir važiuok sistemos automobilių stovèjimo aikštelių III koncepcinis modelis (sudaryta autoriaus)

Fig. 3.11. III conceptional model of park and ride system's car parking's (author's)

Šis koncepcinis modelis suprojektuotas Savanorių prospekte (3.11 pav.). ASA žemės plotas užima 4,9 ha. Joje numatomas ASV skaičius yra 101, iš kurių 1 vieta skirta elektromobiliui su įkrovimo stotele.

Apibendrinti SV sistemos ASA koncepcinių modelių rezultatai pateikti 3.19 lentelèje.

3.19 lentelè. Statyk ir važiuok sistemos automobilių stovèjimo aikštelių koncepcinių modelių rezultatai

Table 3.19 Results of conceptional models of park and ride system's car parking's

\begin{tabular}{lccc}
\hline \multicolumn{1}{c}{ Objektas } & I modelis & II modelis & III modelis \\
\hline Reikalingas žemės plotas, ha & 13,0 & 12,5 & 4,9 \\
\hline ASV skaičius, vnt. & 277 & 233 & 101 \\
\hline ESV skaičius, vnt. & $1+13$ & $1+9$ & $1+10$ \\
\hline $\begin{array}{l}\text { Neiggaliesiems stovèjimo vietur } \\
\text { skaičius, vnt. }\end{array}$ & 11 & 9 & 4 \\
\hline $\begin{array}{l}\text { Dviračių stovejjimo vietų (stovų) } \\
\text { skaičius pirmaisiais metais }\end{array}$ & 4 & 4 & 4 \\
\hline $\begin{array}{l}\text { Keleivių išlaipinimo ir įlaipinimo } \\
\text { zonos plotis, } \text { m }^{2}\end{array}$ & 350 & 1800 & 400 \\
\hline
\end{tabular}

Šių planuojamų SV sistemos ASA sèkmingai veiklai turi būti pasiektas tinkamas VT išvystymo lygis. Kiekvienam miestui, turinčiams SV sistemą, tai 
gyvybiškai svarbiausia SS infrastruktūros dalis. VT sistema užtikrina miesto gyventojų ar svečių keliavimo galimybes (Burinskienè et al. 2009). Greita ir kokybiška VT sistema užtikrins galimybę pasiekti kelionès tikslą visiems SV sistemos ASA vartotojams.

Vilniaus mieste jau yra ruošiama susisiekimo infrastruktūra naujai miesto transporto rūšiai: platinamos miesto gatvès, kuriamos greitojo VT maršrutai, ịrenginejjami kiti susisiekimo ir inžinerinès infrastruktūros objektai.

$2012 \mathrm{~m}$. Vilniaus miesto savivaldybès iniciatyva suburta VT specialistų grupé, kurie vertina naujos VT priemonès atsiradimo galimybes. Neoficialiais duomenimis, planuojamas greitasis bejinis autobusas - BRT (angl. Bus rapid transit). Tai hibridine VT rūšis, perimanti autobuso ir tramvajaus savybes. TP sukuriama atskira (nedidelèse atkarpose, kur atskirų juostų ịrengimas sudètingas ar netikslingas, gali būti ir bendra) transporto infrastruktūra, leidžianti padidinti TP dydị, laidumą ir pervežimą. Ši TP per valandą gali pervežti nuo 15000 iki 30000 keleivių (Cervero 2013).

\subsection{Trečiojo skyriaus išvados}

1. Naudojant daugiatikslius vertinimo metodus buvo atliekamas daugiabučių gyvenamųjų namų automobilių stovejjimo vietų efektyvumo vertinimas, kurio metu buvo lyginami 8 gyvenamieji rajonai. Nustatyta, kad geriausios automobilių stovèjimo sąlygos yra Justiniškių rajone, o blogiausios - Pilaiteje. Tai priklauso nuo skirtingu kriterijų, apibūdinančius atskirus gyvenamuosius rajonus: nuo automobilizacijos lygio, viešojo transporto išvystymo lygio ir gyventojų skaičiaus gyvenamajame rajone.

2. Prekybos centrų automobilių stovėjimo aikšteles suskirsčius ị keturias grupes pagal aikštelių užpildymo rodiklị ir atlikus daugiatikslę vertinimo analizę, gautos visų grupių ribinių verčių reikšmès. Geriausi rezultatai gauti vertinant I-osios grupès prekybos centrų automobilių stovèjimo aikšteles iki 100 vietų, kurie leidžia racionaliau panaudoti žemès plotus automobilių stovejjimui. Tačiau, norint tai pasiekti, turi būti išlaikytos gautos ribinių verčių reikšmès: užstatymo intensyvumas (UI ) nemažiau kaip 1,00, dirbančiųjų gyventojų skaičius ( $D G_{s}$ ) nemažiau kaip 2000, butų skaičius ( $B_{s}$ ) nemažiau kaip 1800. Atlikti skaičiavimai rodo, kad automobilių stovèjimo aikšteliu užpildymo koeficientą $\left(P C_{k}\right)$ galime padidinti iki 1,00 . 
3. Taikant analitinị hierarchijos proceso (AHP) metodą gauti kriterijų svoriu skaitiniai ịverčiai, kuriuos naudojant sudaryta statyk ir važiuok sistemos automobilių stovèjimo aikštelių ịdiegimo eilè ir pagal ją pasiūlyta inovatyvi aikštelių sistema Vilniaus mieste. Skaičiavimai rodo, kad pirmiausia šios sistemos automobilių stovèjimo aikštelès turi būti ịrengiamos Kalvarijų gatvę (kelio Nr. A14) aptarnaujančioje teritorijoje.

4. Atlikus visų linijinių traukos centrų esančių statyk ir važiuok sistemos automobilių stovejjimo aikštelių skaičiavimus nustatyta, kad linijinio traukos centro kokybès indeksas svyruoja nuo 0 iki 1 . Kuo arčiau 1 tuo statyk ir važiuok sistemos aptarnaujančioji teritorija tinkamesnè, arčiau 0 blogesnè. Gauta, kad kelio Nr. A14 linijinio traukos centro aptarnaujančioje teritorijoje kokybės rodiklis lygus 1,13 , tai reiškia, kad šiame maršrute yra per didelis kiekis statyk ir važiuok sistemos automobilių stovejjimo aikštelių ir ši sistema aptarnaujama teritorija yra persotinta aikštelių infrastruktūra. Tačiau atmetus bent vieną aikštelę, kokybès indeksas - 0,94.

5. Sudaryti trys originalūs statyk ir važiuok sistemos automobilių stovèjimo aikštelių koncepciniai modeliai, kurie pritaikyti realiai didmiesčio erdvei. Pirmasis, tai didžiausios statyk ir važiuok sistemos automobilių stovèjimo aikštelès nuo 250 vietų, kurias siūloma ịrengti priemiestinejje miesto zonoje. Antrasis, vidutinio dydžio aikštelès nuo 101 iki 250 vietų, rekomenduojama įrengti vidurinèje miesto zonoje. Trečiasis, mažos aikštelès iki 100 vietų, kurias siūloma ịrengti vidurinèje ar centrinëje miesto zonose. İdiegus pasiūlytas sistemos aikšteles, ịrengus transporto infrastruktūros objektus ir parengus norminius reikalavimus, sudaromos prielaidos sékmingam SV sistemos funkcionavimui.

6. Šio mokslinio tyrimo metu parengta statyk ir važiuok sistemos automobilių stovejjimo vietų parinkimo metodika, kuri gali būti taikoma ne tik Lietuvos miestuose, bet ir užsienio šalyse. Daugiatikslio vertinimo metodų naudojimas yra tinkamas būdas spręsti kompleksines miestų planavimo problemas, randant kompromisą tarp ekspertinių nuomonių. 



\section{Bendrosios išvados}

1. Atlikta mokslinès literatūros automobilių stovejjimo vietų tyrimų analizè parodè, kad sparčiai augantis automobilizacijos lygis perauga ị sisteminę miesto susisiekimo sistemos krizę: gatvèse susidaro nuolatinès transporto grūstys, ilgèja kasdieninių kelionių trukmè, sumažèja VT greitis, eismo kokybė ir kita. Remiantis užsienio šalies mokslininkų patirtimi, pasaulyje yra daug miestų, kuriems iš dalies pavyko išspręsti automobilių stovėjimo vietų problemas urbanizuotose teritorijose.

2. Ištyrus automobilių stovejjimo vietų išdèstymo dèsningumus buvo atlikta ekspertinè analizė daugiabučių namų gyvenamuosiuose rajonuose (A), prekybos centrų automobilių stovejjimo aikštelèse (B) ir pagal Vilniaus miesto bendrojo plano sprendinius planuojamose statyk ir važiuok sistemos automobilių stovejjimo aikštelèse. Nustatyta A, B ir C grupių kriterijų, kurie turi itakos automobilių stovejjimui ịvairiuose miesto vietose, svarba. Visais atvejais ekspertų nuomonès suderintos.

3. Automobilių stovẻjimo vietų tyrimai aštuoniuose Vilniaus miesto daugiabučių namų gyvenamuosiuose rajonuose rodo, kad automobilių stovejimo vietų problema atsirado ne tik sovietmečiu statytuose daugiabučių namų gyvenamuosiuose rajonuose, kai pagal tų laikų normatyvus 4-5 butams buvo skirta 1 automobiliui stovejjimo vieta, bet 
ir naujuose daugiabučių namų gyvenamuosiuose kvartaluose, kai projektuojama 1 automobiliui stovejimo vieta vienam butui. Nustatyta, kad daugiabučiu namų gyvenamuosiuose rajonuose nakties metu (nuo 22 val. vakaro iki 2 val. nakties) nuo 2,2 \% iki 18,4 \% automobilių stovi neleistinose vietose.

4. Nustatyta, kad prekybos centrų automobilių stovejjimo aikštelių užpildymo rodiklis nuo 22.00 val. vakaro iki 2.00 val. nakties svyruoja nuo $1 \%$ iki $100 \%$, o vidutinis užpildymo rodiklis $-27 \%$. Labiausiai prekybos centrų automobilių stovejjimo aikštelių užpildymo rodiklis priklauso nuo automobilių ir dirbančiųjų gyventojų skaičiaus tiriamojoje aplinkoje.

5. Suskirsčius prekybos centrų automobilių stovejjimo aikšteles ị keturias grupes, buvo nustatyta, kad geriausi rezultatai gauti vertinant I-osios grupès prekybos centrų automobilių stovèjimo aikšteles iki 100 vietų. Kompleksiškai planuojant prekybos centrų automobilių stovejjimo aikšteles kartu su daugiabučių namų gyvenamuoju kvartalu, gyventojų automobilius statyti galima nukreipti $\mathfrak{i}$ šios grupès prekybos centru automobilių stovejjimo aikšteles. Antrosios vietos rezultatai gauti vertinant II-osios grupès prekybos centrų automobilių stovejjimo aikšteles. Planuojant šios grupès prekybos centrus daugiabučių namų gyvenamajame rajone, turi būti rastas racionalus santykis tarp gyvenamojo rajono užstatymo formos ir prekybos centro automobilių stovejjimo aikštelès struktūros elementų išdèstymo teritorijoje.

6. Atlikus statyk ir važiuok sistemos automobilių stovèjimo aikštelių išdèstymo daugiatikslę vertinimo analizę priemiestinejje, vidurinėje ir centrinejje miesto zonose, nustatyta šios sistemos automobilių stovejjimo aikštelių ídiegimo eilè. Pagal rangavimo rezultatus pasiūlyta automobilių stovejjimo aikštelių atrankos būdas, kuris leidžia nustatyti statyk ir važiuok sistemos maršrutus ir jų įdiegimo eiliškumą.

7. Sudarytas miesto linijinio traukos centro (magistralinès įvažiavimo ị miestą gatvès) kokybės indekso inovatyvus skaičiavimo matematinis modelis. Jame viena skaitine reikšme išreiškiamas linijinio traukos centro infrastruktūros tinkamumas statyk ir važiuok sistemos automobilių stovèjimo aikštelių plètrai. Šị indeksą galima taikyti vertinant žmonių ir aplinkos gyvenimo kokybę mieste. 


\section{Literatūra ir šaltiniai}

Adomavičius, V. 1991. Automobilizacija ir jos problemos Lietuvoje. Vilnius: Technika. $90 \mathrm{p}$.

Adomavičius, V.; M.; Paliulis, G.; Tupinis, A. 1985. LTRS Mažų miestų transporto sistemų tobulinimas. Vilnius: LIMTI. $44 \mathrm{p}$.

Antucheviciene, J.; Zakarevicius, A.; Zavadskas, E. K. 2011. Measuring congruence of ranking results applying particular MCDM methods, Informatica 22(3): 319-338.

Antucheviciene, J.; Zavadskas, E. K.; Zakarevicius, A. 2012. Ranking redevelopment decisions of derelict buildings and analysis of ranking results, Journal of Economic computation and economic cybernetics studies and research 46(2): 37-62.

Arning, K.; Ziefle, M.; Muehlhans, H. 2013. Join the Ride! User Requirements and Interface Design Guidelines for a Commuter Carpooling Platform. In Design, User Experience, and Usability. User Experience in Novel Technological Environments (pp. 10-19). Springer Berlin Heidelberg.

Arnott, R. 2006. Spatial competition between parking garages and downtown parking policy, Transport Policy 13(6): 458-469.

http://dx.doi.org/10.1016/j.tranpol.2006.05.003 
Arnott, R.; Inci, E. 2010. The stability of downtown parking and traffic congestion, Journal of Urban Economics 68(3): 260-276. http://dx.doi.org/10.1016/j.jue. 2010.05.001

Atkinson, R. W.; Barratt, B.; Armstrong, B. H. R. A.; Anderson, H. R.; Beevers, S. D.; Mudway, I. S.; Kelly, F. J. 2009. The impact of the congestion charging scheme on ambient air pollution concentrations in London, Atmospheric Environment 43(34): 5493-5500. http://dx.doi.org/10.1016/j.atmosenv.2009.07.023

Authority, J. T. 2010. Northeast Florida Regional Transportation Agency Study. Jacksonville/Orlando, Florida.

Bekker, J.; Viviers L. 2008. Using computer simulation to deter-mine operations Policie for a mechanised car park, Simula-tion Modelling Practice and Theory 16(6): 613-625. http://dx.doi.org/10.1016/j.simpat.2008.03.002

Bhaskar, H.; Werghi, N.; Al-Mansoori, S. 2011. Rectangular Empty Parking Space Detection using SIFT based Classification. In VISAPP (pp. 214-220).

Börjesson, M.; Eliasson, J.; Hugosson, M. B.; Brundell-Freij, K. 2012. The Stockholm congestion charges -5 years on. Effects, acceptability and lessons learnt, Transport Policy 20: 1-12. http://dx.doi.org/10.1016/j.tranpol.2011.11.001

Brans, J.-P.; Mareschal, B. 2005. PROMETHEE methods. In'Multiple Criteria Decision Analysis: State of the Art Surveys' Edited by J. Figueira, S. Greco, M. Ehrgott. Springer, Chapter 5:163-195.

Buchanan, C. 1963. Traffic in towns. Penguin Books in association with H.M.S.O., p. 224.

Burinskienė, M.; Jakovlevas-Mateckis, K.; Paliulis, G. M. 2011. Miestotvarka. Vilnius: Technika. 384 p. ISBN 978-609-457-078-0. http://dx.doi.org/10.3846/ 1252-S

Burinskiene, M.; Munch, H. 2003. Traffic development in Lithuania and East Germany (the former GDR) in the past twenty years, Urbanistika ir Architektura 17: 3-10.

Burinskienè, M.; Paliulis, G. 2003. Consistents of car's parking in Lithuanian towns, Transport 18(4): 174-181.

Burinskienè, M.; Paliulis, G. M. 2003. Premises of creation of sustainable urban transport system. Transport Means - 2003: proceedings of the International Conference. Technologija, p. 30-32.

Burinskienè, M.; Ušpalytè-Vitkūnienè, R.; Tuminienė F. 2011. Public Transport Integration into Urban Planning, The Baltic Journal of Road and Bridge Engineering 6(2): 84-90. http://dx.doi.org/10.3846/bjrbe.2011.11

Burnskienè, M.; Paliulis, G.M.; Ušpalytè-Vitkūnienė R. 2009. Miestų viešasis transportas. Vilnius: Technika. 192 p. ISBN 978-9955-28-423-9.

http://dx.doi.org/10.3846/1057-S 
Cairns, M. R. 1998. The development of Park and Ride in Scotland, Journal of Transport Geography 6(4): 295-307.

http://dx.doi.org/10.1016/S0966-6923(98)00016-7

Cervero, R. 2013. Bus Rapid Transit (BRT): An Efficient and Competitive Mode of Public Transport. IURD Working Paper 2013-01.

Chan, N. D.; Shaheen, S. A. 2012. Ridesharing in north america: Past, present, and future, Transport Reviews 32(1): 93-112. http://dx.doi.org/10.1080/01441647. 2011.621557

Chen, G.; Zhou, Y. J.; Cheng, J. X. 2005. Evaluation on the relative transfer efficiency of urban peripheral park and ride facilities, Journal of Traffic and Transportation, 7: 10-13.

Chrest, A. P.; Smith, M.S.; Bhuyan, S.; Iqbal, M.; Monahan, D.R. 2001. Parking structures: planning, design, construction, maintenance, and repair. $3 r d E d$., Chapman \& Hall, New York. 422 p. ISBN 0-7823-7213-1. http://dx.doi.org/10.1007/978-1-4615-1577-7

Christiansen, D. L.; Grady, D. S.; Holder, R. W. 1975. Park-and-ride Facilities: Preliminary Planning Guidelines (No. TTI-2-10-74-205-2 Intrm Rpt.). Texas Transportation Institute, Texas A \& M University System.

Chu, C. P.; Tsai, J. F.; Hu, S. R. 2012. Optimal starting location of an HOV lane for a linear monocentric urban area, Transportation Research Part A: Policy and Practice 46(3): 457-466. http://dx.doi.org/10.1016/j.tra.2011.11.017

Chu, C. P.; Tsai, M. T. 2011. A study of an environmental-friendly parking policy. Transportation Research Part D: Transport and Environment 16(1): 87-91. http://dx.doi.org/10.1016/j.trd.2010.07.009

Clayton, W.; Ben-Elia, E.; Parkhurst, G.; Ricci, M. 2013. Where to park? A behavioural comparison of bus-based park and ride and city centre car park usage in Bath, UK, Journal of Transport Geography 36: 124-133. http://dx.doi.org/ 10.1016/j.jtrangeo.2014.03.011

Czerwinski, S. 2013. System park and ride we Wrocławiu - przykład parkingu przy stadionie miejskim, Transport Miejski i Regionalny 10-18.

Dijk, M.; Montalvo, C. 2011. Policy frames of Park-and-Ride in Europe, Journal of Transport Geography 19(6): 1106-1119.

http://dx.doi.org/10.1016/j.jtrangeo.2011.05.007

Dimitrijevic, D.; Nedic, N.; Dimitrieski, V. 2013. Real-time carpooling and ridesharing: Position paper on design concepts, distribution and cloud computing strategies, In Computer Science and Information Systems (FedCSIS) 2013 Federated Conference on (pp. 781-786). IEEE.

European Commission (EC) 2009. Žalioji knyga „TEN-T politikos peržiūra. Siekiant geriau integruoto transeuropinio transporto tinklo igyvendinant bendrają transporto politiką“ [žiūrèta 2014 m. gegužès 20 d.]. Prieiga per internetą: 
http://eurlex.europa.eu/LexUriServ/LexUriServ.do?uri=COM:2009:0044:FIN:LT:P DF

European Commission (EC) 2011. Baltoji knyga „Bendros Europos transporto erdvės kūrimo planas. Konkurencingos efektyviu ištekliųnaudojimu grindžiamos transporto sistemos kūrimas“ " [žiūrèta 2014 m. gegužès 20 d.]. Prieiga per internetą: http://eurlex.europa.eu/LexUriServ/LexUriServ.do?uri=COM:2011:0144:FIN:LT:P DF

Евланов, Л. Г. 1984. Теория и практика принятия решений [Evlanov, L. Sprendimų prièmimo teorija ir praktika]. Москва: Экономика. 176 с.

Fensterer, V.; Küchenhoff, H.; Maier, V.; Wichmann, H. E.; Breitner, S.; Peters, A.; Cyrys, J. 2014. Evaluation of the Impact of Low Emission Zone and Heavy Traffic Ban in Munich (Germany) on the Reduction of PM10 in Ambient Air, International Journal of Environmental Research and Public Health 11(5): 5094-5112. http://dx.doi.org/10.3390/ijerph110505094

Foster, C.D. 1963. The Transport Problem, Blackie, London.

Fouladgar, M. M.; Yazdani-Chamzini A.; Lashari, A.; Zavadskas, E. K.; Turskis, Z. 2012a. Maintenance strategy selection using AHP and COPRAS under fuzzy environment, International Journal of Strategic Property Management 16(1): 85104. http://dx.doi.org/10.3846/1648715X.2012.666657

Fouladgar, M. M.; Yazdani-Chamzini A.; Zavadskas, E. K.; 2012b. Risk evaluation of tunneling projects, Archives of Civil Mechanical Engineering Oxford 12(1): 112. http://dx.doi.org/10.1016/j.acme.2012.03.008

Fouladgar, M. M.; Yazdani-Chamzini, A.; Zavadskas, E. K. 2011. An integrated model for prioritizing strategies of the Iranian mining sector, Technological and Economic Development of Economy 17(3): 459-483.

http://dx.doi.org/10.3846/20294913.2011.603173

Frost, M. 1974. Park and ride: A rising tide. Public Works 105(9).

Galland, D. 2014. Integrated Territorial Management and Governance: Proceedings of the ESPON/ENECON III Postgraduate Workshop.

Gholami, A.; Taghizadeh, Y.; Tian, Z. 2014. Classification of taxi khattee (jitney) lines based on topography and line cost indices, Transportation Research Part A: Policy and Practice 59: 239-249. http://dx.doi.org/10.1016/j.tra.2013.12.004

Godfrey, J. W. 1970. The mechanism of A road network, Traffic Engineering and Control 11: 323-327.

Goel, R. K.; Singh, B.; Zhao, J. 2012. Underground infrastructures: planning, design, and construction. Butterworth-Heinemann. 266 p. ISBN 978-0-12-397168-5.

Grigonis, V. 2005. Miesto strukturos įtaka energetiniu resursų suvartojimui vežant keleivius: Daktaro disertacija. Vilniaus Gedimino technikos universitetas. Vilnius. $149 \mathrm{p}$. 
Grigonis, V., Paliulis, G.M. 2009. Traffic Restriction Policies in Lithuanian Cities Based onVilnius Case Study, The Baltic Journal of Road and Bridge Engineering 4(1): 36-44. http://dx.doi.org/10.3846/1822-427X.2009.4.36-44

Guo, Z.; Ren, S. 2013. From Minimum to Maximum: Impact of the London Parking Reform on Residential Parking Supply from 2004 to 2010?, Urban Studies 50(6): 118-1200. http://dx.doi.org/10.1177/0042098012460735

Hickman, R.; Hall, P.; Banister, D., 2013. Planning more for sustainable mobility, Journal of Transport Geography 33: 210-219.

http://dx.doi.org/10.1016/j.jtrangeo.2013.07.004

Holguín-Veras, J.; Reilly, J.; Aros-Vera, F.; Yushimito, W.; Isa, J. 2012. Park-andRide Facilities in New York City. Transportation Research Record, Journal of the Transportation Research Board 2276(1): 123-130.

http://dx.doi.org/10.1016/j.trb.2012.02.011

Huang, C. C.; Wang, S. J. 2010. A hierarchical bayesian generation framework for vacant parking space detection. Circuits and Systems for Video Technology, IEEE Transactions on 20(12): 1770-1785.

Hwang, C. L.; Yoon, K. 1981. Multiple attribute decision-making methods and applications. A state of the art survey. Lecture Notes in Economics and Mathematical Systems. Springer Verlag, Berlin, Heidelberg, New York. 259 p.

Ieromonachou, P.; Potter, S.; Warren, J. P. 2006. Norway's urban toll rings: Evolving towards congestion charging?, Transport Policy 13(5): 367-378. http://dx.doi.org/10.1016/j.tranpol.2006.01.003

Invernizzi, G.; Ruprecht, A.; Mazza, R.; De Marco, C.; Močnik, G.; Sioutas, C.; Westerdahl, D. 2011. Measurement of black carbon concentration as an indicator of air quality benefits of traffic restriction policies within the ecopass zone in Milan, Italy. Atmospheric Environment 45(21): 3522-3527.

http://dx.doi.org/10.1016/j.atmosenv.2011.04.008

Jakimavičius, M.; Burinskienè, M. 2010. Route planning methodology of an advanced traveller information system in Vilnius city, Transport 25(2): 171-177. http://dx.doi.org/10.3846/transport.2010.21

Jiau, M. K.; Huang, S. C.; Lin, C. H. 2013. Optimizing the Carpool Service Problem with Genetic Algorithm in Service-Based Computing. In Services Computing (SCC), 2013 IEEE International Conference on (pp. 478-485). IEEE.

Johnson, S. 1968. U.S. Patent No. 3,395,815. Washington, DC: U.S. Patent and Trademark Office.

Juškevičius, P. 2003. Miestų planavimas. Vilnius: Technika. 144 p. ISBN 9986-0505-508-3.

Juškevičius, P.; Burinskienè, M.; Paliulis, G. M.; Gaučè, K. 2013. Urbanistika: procesai, problemos, planavimas, plètra. Vilnius: Technika. 384 p. ISBN 978-609457-429-0. http://dx.doi.org/10.3846/1447-S 
Juškevičius, P.; Valeika, V.; Burinskienė, M.; Paliulis, G. M.. 2006. Lietuvos miestų susisiekimo sistemos. Klaipėda. Vilnius: Technika. 184 p. ISBN 9955-28-048-4.

Kaklauskas, A.; Zavadskas, E. K.; Naimaviciene, J.; Krutinis, M.; Plakys, V.; Venskus, D. 2010. Model for a complex analysis of intelligent built environment, Automation in Construction 19(3): 326-340.

http://dx.doi.org/10.1016/j.autcon.2009.12.006

Kalibatas, D.; Zavadskas, E. K.; Kalibatienè, D. 2011. The concept of the ideal indoor environment in multi-attribute assessment of dwelling-houses, Archives of Civil and Mechanical Engineering Wroclaw 11(1): 89-101.

http://dx.doi.org/10.1016/S1644-9665(12)60176-9

Kanapeckiene, L.; Kaklauskas, A.; Zavadskas, E. K.; Seniut, M. 2010. Integrated knowledge management model for construction projects, Engineering Applications of Artificial Intelligence 23(7): 1200-1215.

http://dx.doi.org/10.1016/j.engappai.2010.01.030

Karamychev, V.; Van Reeven, P. 2011. Park-and-ride: Good for the city, good for the region?, Regional Science and Urban Economics 41(5): 455-464. http://dx.doi.org/10.1016/j.regsciurbeco.2011.03.002

Kendall, M. 1970. Rank correlation methods. 4th Ed. London: Griffin. 272 p.

Kęsek, J. 2007. Parkingi podziemne w Krakowie. Zeszyty Naukowo-Techniczne Stowarzyszenia Inżynierów i Techników Komunikacji Rzeczpospolitej Polskiej Oddział w Krakowie, Materiaty konferencyjne 80(134): 75-94.

Khakbaz, A.; Nookabadi, A. S.; Shetab-bushehri, S. N. 2013. A Model for Locating Park-and-Ride Facilities on Urban Networks Based on Maximizing Flow Capture: A Case Study of Isfahan, Iran, Networks and Spatial Economics 13(1): 43-66. http://dx.doi.org/10.1007/s11067-012-9172-4

Kildiene, S.; Kaklauskas, A.; Zavadskas, E. K. 2011. COPRAS based comparative analysis of the European country management capabilities within the construction sector in the time of crisis, Journal of Business Economics and Management 12(2): 417-434. http://dx.doi.org/10.3846/16111699.2011.575190

Klementschitz, R.; Stark, J. 2008. Shoping centres and car use: Car park regimentations as a potential lever, in The 7th International Conference on Environmental engineering, Urban transport systems 3: 967-973, Vilnius.

Kodransky, M.; Hermann, G. 2011. Europe's parking U-Turn: from accommodation to regulation. Institute for Transportation \& Development Policy (ITDP), New York.

Kombinuotų keleivių kelionių skatinimo, diegiant Park\&Ride, Bike\&Ride ir kitas koncepcijas, tyrimas 2012. Galimybiu studija [interaktyvus]. [žiūrèta $2014 \mathrm{~m}$. gegužès 28 d.]. Prieiga per internetą: http://www.transp.lt/files/uploads//Parka-Rideataskaita_20121219_galutine.pdf 
Lashari, A.; Yazdani-Chamzini A.; Fouladgar, M. M.; Zavadskas, E. K.; Shafiee, S.; Abbate, N. 2012. Equipment selection using fuzzy multi criteria decision making model: key study of Gole Gohar iron mine, Inžinerine ekonomika [Egineering Economics] 23(2): 125-136.

Lazda, Z.; Smirnovs, J. 2014. Application of design speed for urban road and street network, Baltic Journal of Road and Bridge Engineering 9(1): 26-30. http://dx.doi.org/10.3846/bjrbe.2014.04

Lim, T. E. 2010 Influence of transport pollution on health of the person. Literature review. Yekologiya Cheloveka/Human Ecology, 1: 4-9.

Lipnickas, M.; Nagurnas, S. 2012. Vairuotojų psichofiziologinių savybių nustatymo ir vertinimo metodai. 15-osios Lietuvos jaunuju mokslininku konferencijos „Mokslas - Lietuvos ateitis“ teminès konferencijos „,Transporto inžinerija ir vadyba“ straipsniu rinkinys. Vilnius : Technika, ISBN 9786094571329. p. 405-409.

Longstreth, R. W. 1998. City center to regional mall: architecture, the automobile, and retailing in Los Angeles, 1920-1950. MIT Press.

McDonald, S. 2012. Cars, Parking, and Sustainability, in Transportation research forum (TRF). Conference proceedings [interaktyvus]. May 15-27, 2012, Tampa, Florida. [žiūrèta $2014 \mathrm{~m}$. gegužès $12 \mathrm{~d}$.]. Prieiga per internetą: http://www.trforum.org/forum/downloads/2012_112_Cars_Parking_Sustain.pdf.

McDonnell, S.; Madar, J.; Been, V. 2011. Minimum parking requirements and housing affordability in New York City, Housing Policy Debate 21(1): 45-68. http://dx.doi.org/10.1080/10511482.2011.534386

Medineckiene, M.; Bjork, F.; 2011. Owner preferences regarding renovation measures the demonstration of using multi-criteria decision making, Journal of Civil engineering and Management 17(2): 284-295.

Meek, S.; Ison, S.; Enoch, M. 2010. UK local authority attitudes to Park and Ride. Journal of Transport Geography, 18(3): 372-381.

http://dx.doi.org/10.1016/j.jtrangeo.2009.09.005

Meek, S.; Ison, S.; Enoch, M. 2011. Evaluating alternative concepts of bus-based park and ride, Transport Policy 18(2): 456-467.

http://dx.doi.org/10.1016/j.tranpol.2010.09.006

Metcalfe, P. J. 2013. Evaluation of remotely piloted aircraft in surveying applications.

Millard-Ball, A. 2002. Putting on their parking caps. Planning. April, 2002, 16-21.

Mingardo, G. 2013. Transport and environmental effects of rail-based Park and Ride: evidence from the Netherlands, Journal of Transport Geography 30: 7-16. http://dx.doi.org/10.1016/j.jtrangeo.2013.02.004

Mingardo, G.; Van Meerkerk, J. 2012. Is parking supply related to turnover of shopping areas? The case of the Netherlands, Journal of Retailing and Consumer Services 19(2): 195-201. http://dx.doi.org/10.1016/j.jretconser.2011.12.001 
Noel, E. C. 1988. Park-and-ride: alive, well, and expanding in the United States, Journal of Urban Planning and Development 114(1): 2-13.

http://dx.doi.org/10.1061/(ASCE)0733-9488(1988)114:1(2)

Parkhurst, G. 2000. Link-and-ride: a longer-range strategy for car-bus interchange: This month's contributors, Traffic engineering \& control 41(8): 319-324.

Parkhurst, G.; Richardson, J. 2002. Modal integration of bus and car in UK local transport policy: the case for strategic environmental assessment, Journal of Transport Geograph, 10(3): 195-206.

http://dx.doi.org/10.1016/S0966-6923(02)00011-X

Pech, A., Warmuth, G., Jens, K., \& Zeininger, J. 2006. Parkhäuser-Garagen. SpringerWienNewYork. 453 p. ISBN 978-3-211-89238-1.

Pęski, S., Czechowski, F. 2001. Miejskie parkingi podziemne w Warszawie, Inżynieria i Budownictwo 57: 203-206.

Pęski, S.; Czechowski, F. 2001. Miejskie parkingi podziemne w Warszawie, Inżynieria i Budownictwo 57: 203-206.

Pierce, G.; Shoup, D. 2013. Getting the prices right: an evaluation of pricing parking by demand in San Francisco, Journal of the American Planning Association 79(1): 67-81. http://dx.doi.org/10.1080/01944363.2013.787307

Podvezko, V. 2011. The Comparative Analysis of MCDA Methods SAW and COPRAS, Inzinerine Ekonomika - Engineering Economics 22(2): 134-146.

Podvezko, V.; Podviezko, A. 2010a. Dependence of multi-criteria evaluation result on choice of preference functions and their parameters, Technological and Economic Development of Economy 16(1): 143-158.

http://dx.doi.org/10.3846/tede.2010.09

Podvezko, V.; Podviezko, A. 2010b. Use and choice of preference functions for evaluation of characteristics of socio-economical processes, The 6th International Scientific Conference Business and management'2010: selected papers, Vol. 2, May 13-14, 2010 Vilnius, Lithuania Vilnius: Technika, 1066-1071.

Podvezko, V.; Sivilevičius, H. 2013. The use of AHP and rank correlation methods for determining the significance of the interaction between the elements of a transport system having a strong influence on traffic safety, Transport, 28(4): 389403. http://dx.doi.org/10.3846/16484142.2013.866980

Prud'homme, R.; Bocarejo, J. P. 2005. The London congestion charge: a tentative economic appraisal, Transport Policy 12(3): 279-287.

http://dx.doi.org/10.1016/j.tranpol.2005.03.001

Psiloglou, B. E.; Larissi, I. K.; Petrakis, M.; Paliatsos, A. G.; Antoniou, A.; Viras, L. G. 2013. Case studies on summertime measurements of O3, NO2, and SO2 with a DOAS system in an urban semi-industrial region in Athens, Greece, Environmental monitoring and assessment 185 (9): 7763-7774. 
Reinhardt, L. B.; Clausen, T.; Pisinger, D. 2013. Synchronized dial-a-ride transportation of disabled passengers at airports, European Journal of Operational Research 225(1): 106-117. http://dx.doi.org/10.1016/j.ejor.2012.09.008

Rice, C. 2011. Marina City: Bertrand Goldberg's Urban Vision, The Journal of Architecture 16(4): 575-579. http://dx.doi.org/10.1080/13602365.2011.599234

Rye, T.; Ison, S. 2007. Use and Impact of Maximum Parking Standards in Scotland. In Transportation Research Board 86th Annual Meeting (No. 07-2527).

Saaty, T. L. 1980. The Analytic Hierarchy Process: Planning, Priority Setting, Resource Allocation. New York: McGraw-Hill. 287 p.

Schuitema, G.; Steg, L.; Forward, S. 2010. Explaining differences in acceptability before and acceptance after the implementation of a congestion charge in Stockholm, Transportation Research Part A: Policy and Practice 44(2): 99-109. http://dx.doi.org/10.1016/j.tra.2009.11.005

Šeštokas, V.V. 1973. Miestų transportas (Городской транспорт). Vilnius, 276 p.

Shin, J. H.; Jun, H. B. 2014. A study on smart parking guidance algorithm, Transportation Research Part C: Emerging Technologies 44: 299-317. http://dx.doi.org/10.1016/j.trc.2014.04.010

Shoup, D. C. 1999. The trouble with minimum parking requirements, Transportation Research Part A: Policy and Practice 33(7): 549-574. http://dx.doi.org/10.1016/S0965-8564(99)00007-5

Simićević, J.; Milosavljević, N.; Maletić, G.; Kaplanović, S. 2012. Defining parking price based on users' attitudes, Transport Policy 23: 70-78. http://dx.doi.org/10.1016/j.tranpol.2012.06.009

Smeed, R.I. 1966. Road capacity of city centres, Traffic Engineering and Control 8: 455-458.

Smeed, R.I. 1968. Traffic studies and urban congestion, J. of Transport Economics and Policy 2: 33-70.

Statybos techninis reglamentas STR 2.06.01:1999 „Miestu miesteliu ir kaimu susisiekimo sistemos “, $2014 \mathrm{~m}$. aktuali redakcija.

Steadman, P. 2011. Evolution of a building type: the case of the multi-storey garage, The Journal of Space Syntax 2(1): 1-25.

Szarata, A. 2007. Ocena efektywności funkcjonalnej systemu parkingów przesiadkowych (Park and Ride), Transport Miejski i Regionalny, 29-35.

Tello, E.; Eritja I Mathieu, D.; Resinger, H. 1997. Supermanzanas: Una propuesta para abrir espacio a bicicletas y peatones en ciudades densas (el caso de Barcelona). In International bicycle planning conference 259-262.

Theurillat, T.; Crevoisier, O. 2013. The sustainability of a financialized urban megaproject: the case of Sihlcity in Zurich, International Journal of Urban and Regional Research 37(6): 2052-2073. 
http://dx.doi.org/10.1111/j.1468-2427.2012.01140.x

Thompson, J.; Berman, R. 2012. The Congestion Charge in London: A Strategy for Sustainable Transportation.

Turskis, Z.; Zavadskas, E. K. 2010. A novel method for multiple criteria analysis: Grey Additive Ratio Assessment (ARAS-G) method, Informatica 21(4): 597-610.

Ušpalytè-Vitkūnienè, J. 2006. Miestų viešojo transporto maršrutinio tinkle modeliavimas ir plètra (Vilniaus miesto pavyzdžiu) . Daktaro disertacija. Vilniaus Gedimino technikos universitetas. Vilnius. 131 p.

Ušpalytè-Vitkūnienè, R.; Grigonis, V.; Paliulis, G. M. 2012. The extent of influence of O-D matrix on the results of public transport modeling, Transport 27()2: 165171. http://dx.doi.org/10.3846/16484142.2012.693894

Ustinovičius, L.; Zavadskas, E. K. 2004. Statybos investicijų efektyvumo sistemotechninis įvertinimas. Vilnius: Technika. 220 p. ISBN 9986-05-806-6.

Vaitkus, A.; Vorobjovas, V.; Čygas, D.; Pakalnis, A. 2014 Soft asphalt pavement solution for low-volume roads in changing climate and economy, Advanced materials research: Biological systems and materials 934 (2014): 47-52. http://dx.doi.org/10.4028/www.scientific.net/AMR.934.47

Valstybine teritorijų planavimo ir statybos inspekcija prie Aplinkos Ministerijos (VTPSI). 2009. Teisès aktu, reglamentavusiu teritoriju planavimo, statybos ir valstybinès statybos kontrolès tvarka Lietuvoje 1947-1992 metais, sarašas [interaktyvus]. [žiūrèta $2014 \mathrm{~m}$. gegužès 15 d.]. Prieiga per internetą: http:// vtpsi.1t/vtpsi_dokum/istor.doc

Waersted, K. 1992. Automatic toll ring no stop electronic payment systems in Norway-systems layout and full scale experiences, In Road Traffic Monitoring, IEE Conf. Pub. 355: p. 16.

Wang, C.; Zhang, H.; Yang, M.; Wang, X.; Ye, L.; Guo, C. 2014. Automatic Parking Based on a Bird's Eye View Vision System. Advances in Mechanical Engineering, 2014.

Weiner, E.; Weiner, E. 2013. Improving Intergovernmental Coordination, Urban Transportation Planning in the United States: History, Policy, and Practice 53-68.

Yushimito, W. F.; Aros-Vera, F.; Reilly, J. J. 2012. User rationality and optimal park-and-ride location under potential demand maximization, Transportation Research Part B: Methodological 46(8): 949-970.

Zagorskas, J. 2007. Miestų kompaktiškumas ir darniosios plètros modeliavimas. Daktaro disertacija. Vilniaus Gedimino technikos universitetas. Vilnius. 123 p.

Zaranka, J. 2012. Kelių transporto priemonių vairuotojų elgsenos veiksnių įtakos eismo saugai tyrimas. Daktaro disertacija. Vilniaus Gedimino technikos universitetas. Vilnius. 116 p. 
Zavadskas, E. K.; Kaklauskas, A. 1996. Pastatu sistemotechninis ịvertinimas [Multiple Criteria Evaluation of Buildings]. Vilnius: Technika. 275 p. (in Lithuanian).

Zavadskas, E. K.; Turskis, Z.; Ustinovičius, L.; Sevcenko, G. 2010a. Attributes weights determining peculiarities in multiple attribute decision making methods, Inžinerine ekonomika - Engineering Economics 21(1): 32-43.

Канаян, К.; Канаян, Р.; Канаян, А. 2005. Проектирование магазинов и торговых центров. М.: Юнион-Стандарт Консалтинг. 



\section{Autoriaus mokslinių publikacijų disertacijos tema sąrašas}

\section{Straipsniai recenzuojamuose mokslo žurnaluose}

Maliene, V.; Grigonis, V.; Palevičius, V.; Griffiths, S. 2011. Geographic information system: Old principles with new capabilities. Urban Design International, 16(1), 1-6. ISSN: 1357-5317 (ISI Web of Science).

Palevičius, V.; Paliulis, G. M.; Venckauskaite, J.; Vengrys, B. 2013. Evaluation of the requirement for passenger car parking spaces using multi-criteria methods. Journal of Civil Engineering and Management, 19(1), 49-58. ISSN 1392-3730 print, ISSN 18223605 online (ISI Web of Science).

Palevičius, V., Lazauskaitė D. 2014. Sistemos „Statyk ir važiuok“ plètros didžiuosiuose Lietuvos miestuose modelis. Journal of Science - future of Lithuania, 6(4), 456-460. ISSN 2029-2341 print, ISSN 2029-2252 online.

\section{Straipsniai kituose leidiniuose}

Zagorskas, J.; Palevičius, V. 2011a. Estimation of efficiency of retail centres car parking-lots, in 8th International Conference "Environmental Engineering": selected papers, vol. 3. ed. by D. Čygas, K. D. Froehner. May 19-20, 2011, Vilnius, Lithuania. Vilnius: Technika, 1014-1017. ISBN 978-9955-28-826-8. (ISI Proceedings). 
Burinskienè, M.; Palevičius, V.; Paliulis, M. G.; Skrodenis, E. 2014. Possibilities for the Implementation of Park and ride Scheme in Vilnius City. 9th International Conference "Environmental Engineering", May 22-23, 2014, Vilnius, Lithuania CD. Vilnius: Technika, 2014. ISBN 978-609-457-690-04. 


\section{Summary in English}

\section{Introduction}

\section{Problem formulation}

One of the most relevant problems of the largest Lithuanian cities inhabitants is lack of parking's in territories of city. There are not enough parking's in the Old town, in the city centre, in the courts of block of flats, near medical institutions and other important objects. The lack of parking's in Lithuanian cities was determined by unpredictable development processes of communication system. It all began about two decades ago when Lithuania regained its independence. The transportation of old used cars from western European countries, rapidly rising level of motorization, growing economy of country, and increasing society's standard of living changed development of system infrastructure. As a result, inhabitants became dependent on car.

In Lithuanian residential areas of largest cities formed two types of parking problems. The first problem is in residential areas of block of flats equipped in the Soviet Union. The second problem in new residential areas of equipped block of flats. Parking's equipped in the Soviet Union fail to meet the existing minimal normative requirements. Due to lack of places people end up parking their car on streets, pedestrian and cycle paths, lawns, playgrounds and etc. Parking's of new block of flats designed by existing minimal normative requirements. Though, the growing mobility of inhabitants, 
the distance and the duration of work travelling's induce having more than one car in a family and the existing parking's are not enough for all cars.

In order to reduce the use of car in the city is necessary to develop competitive public transport and to improve quality of passengers transportation process. It is necessary to stimulate systems of composite transport travels so that public transport would compete successfully with car (Park and ride, Bike and Ride, Kiss and Ride et al.).

Available data suggested that use of Park and ride system is increasing in the world. In accordance with experience of foreign countries, successful activity of Park and ride system depends on many factors: physical structure of the city, opportunity of land clearing, stimulation of public transport, management policy etc. However, the main object of infrastructure is parking which is involved in the whole activity of Park and ride. There are no parking's in Lithuania that would be officially combined with traditional system of public transport. Therefore, it can be concluded that in Lithuanian cities this system is not properly investigated and there is no method how to equip parking lots. It is necessary to evaluate the development of parking's for system of Park and ride in the Lithuanian largest cities in order to compete successfully with other city systems of public transport.

\section{Relevance of the thesis}

The growing level of motorization is relevant to the need of parking in the city which influence on urbanization and worsen the people's quality of life (Hongbing and Zhaokang 2011). The need of parking's in the cities is different because under such historical circumstances of various purposes buildings arrangement. In this case the most important criteria while planning parking lot is working format of parking, not space of parking-lot (Burinskienè et al. 2011).

Scientists have established that for one car parking is necessary 5-6 places (homework-supermarket-home) i.e. for each car $100 \mathrm{~m}^{2}$ of territory is needed. Town planners suggest that in large cities with millions of inhabitants for needs of communication system is necessary about $40 \%$ (somewhere even more - $60 \%$, e.g. Los Angeles, JAV) of total area, in other large cities $20-25 \%$, while in smaller cities about $10 \%$ of area (Juškevičius et al. 2013).

The parking regulation process in Lithuania and in the world is negotiable and political question. For the regulation process of parking's, especially in city centres; legal, organizational and financial mechanisms are necessary (Juškevičius et al. 2006). Though, today Lithuanian and other countries cities regulation system of parking is standardized by traditional list of form (lt. STR, ru. CHиП, ge. DIN, ch. SN, ee. RTL etc.). The principles for the measurement of standards of parking's are outdated, not sufficient to meet existing need; therefore, we need to change them (Wilson 2013).

Thesis relevance can be confirmed with European Commission documents in which indicated to solve faster problems of mobilization level, jam and air pollution in European cities.

In confirmed and published Official Journal of European Commission ( February, 2009) in the Green Paper's Agenda for Action (EC 2007) and in the publication of White 
Paper (EC 2011) designated to install conceptions of combined journey systems. In this case, the purpose of European tranpsort space establishment will be realized. By 2030 in European countries the use of cars powered by traditional fuel in cities will be reduced twice and by 2050 will not be such cars in cities. The EU's Aid for Lithuanian largest cities designated (Vilnius, Kaunas, Klaipeda, Šiauliai and Panevėžys) for the period of 2014-2020 Park and ride development of parking's lots. This support is given according to the second priority of cities development - The development of walking and sustainable urban transport system according to objective 2.1 - Increase competetiveness of public transport. Instrument 2.2.1 - The development of interaction system of private and public transport distant from city centres and city access (development of Park and ride parking lots).

\section{Research object}

Thesis object - distribution system of personal travelling cars parking in large city.

\section{Aim of the thesis}

Suggest developmental model of parking in the city and to give original conceptual solutions of parking's development.

\section{Objectives of the thesis}

1. To analyse scientific literature related to the lack of parking's.

2. To investigate parking lots in residential areas of Vilnius City and parking lots of supermarkets.

3. To designate the inhabitants of the block of flat need to use the parking lots, during non shopping time.

4. Create supermarkets parking lots valuation system that would partially solve the lack of parking's in parking lots of block of flats.

5. Propose the systematic selection strategy of Park and ride for parking lots in the city and propose requirements for planning infrastructure of communication system.

\section{Research methodology}

In thesis these methods of analysis are used: scientific theoretical analysis, multiattribute and field experiments.

Following the method of scientific theoretical analysis of modern scientific literature, European Commission Publications and other legal documents is prepared. 
Following the field experiments the number of cars kept in territories of block of flats and in parking lots of supermarkets, the keeping conditions of cars, the filling coefficients of parking lots, the need of parking's and etc. were determined.

While using experimental methods criteria of parking's determined and their weights calculated. Later various multitask methods are applied: according to methods of TOPSIS, SAW, COPRAS, PROMETHEE, the priority row of parking lots and parking's is accessed. The filling coefficients of supermarkets parking lots are determined and the systematic selection strategy of Park and ride of parking lots in the city is suggested.

\section{Scientific novelty of the thesis}

These new results for the study of civil engineering are obtained while preparing the thesis:

1. The criteria system which can be used in a stage of complex city planning created for development of supermarkets parking lots.

2. By the method of the analytic hierarchy process (AHP) received numeric iterators of criteria weights, as a result, a priority row of Park and ride parking system was made, on this basis, an innovative system of parking lots in Vilnius City was suggested.

3. Three original Park and ride parking lots system conceptual models which are adapted to real space of large city are organized.

\section{Practical value of research findings}

In thesis criteria system, which can be practically applied in a stage of complex practical planning of supermarkets parking lots is determined. It is an instrument that makes it possible for territory planners to calculate mathematically the number of parking lots in residential areas while evaluating variants of parking lots to supermarkets. The created system of criteria is suitable for Lithuanian largest cities and other similar cities of foreign countries.

According to the support of European Union of 2014-2020 period a sponsorship for five Lithuanian cities for developement of park and ride system is planned. Also a method for the most rational places of dislocation of Park and ride system is suggested. Three conceptual models of park and ride system are additionally detailed, adapted and visualized in real space of city.

\section{Defended statements}

1. In urbanized territories of residential areas equipped parking lots of supermarket can be used more effectively for parking during the night. 
2. While planning residential area of block of flats in coordinated manner and parking lot in supermarkets in urban territories, a particular part of cars of inhabitants of block of flats can be shifted to parking lot of supermarket.

3. It is usually impossible to determine Park and ride system's importance and influence on its efficiency with planned laboratory and field's physical experiments for this purpose multi-criteria methods are the most suitable.

\section{Approval of research findings}

Relating to this thesis subject there are published five scientific publications: two in Scientific Journals that are listed in Thomson Reuters Web Knowledge (ISI Web of Science). The first scientific publication published in foreign magazine which does not have index of citation (Maliene et al. 2011), the second one has index of citation (Palevičius et al. 2013). One of them included in publications of international databases (Palevičius and Lazauskaitè 2014), one in material of ISI Proceedings conference (Zagorskas and Palevičius 2011), one in reviewed material international conferences (Burinskienè et al. 2014).

The results of thesis research announced in five scientific conferences in Lithuania and foreign countries:

- $14^{\text {th }}$ conference of young Lithuanian scientists - Civiline inžinerija ir geodezija; 2011, Vilnius;

- $8^{\text {th }}$ international conference - Environmental engineering; 2011, Vilnius (Zagorskas and Palevičius $2011 \mathrm{a}, \mathrm{b}$ );

- International conference of VISBY project - Capacity building in sustainable urban planning and development in Lithuania, Russia, Sweden and Ukraine; 2013, Nida;

- International conference - III Postgraduate workshop of the ESPON/ENECON project; Aalborg, Denmark (Galland 2014);

- $9^{\text {th }}$ international conference - Environmental engineering; 2014, Vilnius (Burinskiene et all. 2014).

\section{Structure of the thesis}

Thesis consists of introduction, 3 chapters, general conclusions, list of literature, list of publications.

Thesis composed of 140 pages, 36 tables and 31 pictures. Thesis is written using 135 scientific and other sources. 


\section{The analysis of the scientific works dedicated to the problems of car parking spaces in cities}

Since 1970s the level of motorization in Lithuanian cities began growing rapidly. Progressively appeared to many vehicles because the communication system of cities did not develop evenly with motorization. Streets network was technically undeveloped, the lack of parking's and other factors stimulated the greater need of personal cars in the city. Lithuanian and foreign scientists have established that in large cities for one car parking 5-6 places are necessary, i.e. for each car at least $100 \mathrm{~m}^{2}$ area is required. Scientists agreed on that the most important criterion in planning parking lot is working aspect of single parking instead of parking area.

Based on foreign literature search, there are various ways in foreign cities how to enlarge working aspect of single parking. Progressive taxes in cities centres for parking while changing standardized calculating principles of parking, creating innovative tax levies systems, installing multi-storey and underground garages.

Based on Lithuanian literature research (Šeštokas, Adomavičius, Juškevičius, Burinskiene etc.), the lack of parking's in large cities from scientific point of view, is a very little researched problem. It focuses, in particular, on the research and analysis of parking's and their changes for standards calculating principles.

In full knowledge of foreign and Lithuanian scientific literature parking aspects of research, it can be concluded that in order to improve working of parking's in the city is necessary to define analysed territory. In thesis the Vilnius City which is divided into three zones is chosen as concretized object of research. The first one is central zone (The Old town and the city centre), the second one is middle zone (residential areas, supermarkets, business enterprises, medical institutions, education institutions etc.) and suburban zone (airport, manufacturing and industries companies, various business centres etc.).

The overview of scientific literature in this chapter showed that more attention to effective use of territory for parking's, not for expansion of parking's in the city is needed.

\section{The theoretical investigation and analysis of the spaces for car parking}

Vilnius is a Lithuanian city with the largest population and the biggest number of cars; this creates major parking shortage problems. There are two parking issues: the first one is the long term parking problem when cars are parked in residential districts (most often in the night time); the second one is the temporary parking problem, when a car is parked for a limited period of time (near a workplace, a shopping mall, a hospital or other entertainment centres). Since these two problems correlate, they have to be solved 
together. Investigations are carried out in 8 residential areas and in 49 shopping mall parking lots in order to solve the long term parking problem. The main goal of these investigations is to determine the demand for shopping mall parking lot spaces not for shopping, but in the night time by inhabitants of residential areas.

The research shows that $2.2-18.4 \%$ of cars, parked in residential areas in the night time, are parked in violation of the road traffic regulations. The density of passenger cars parked in residential areas amounts to $35.2-61.0 \mathrm{veh} / \mathrm{ha}$. It was found that the level of occupied parking spaces in shopping mall parking lots reaches up to $27 \%$. Accordingly, when shopping mall car parking lots are planned in residential areas, the occupied spaces are not taken into account; therefore, there are no attempts to use the land for parking in a more complex way. As a result, a criteria system for parking in the city was compiled after the research. This system enables the increase of the occupancy of shopping mall parking lot coefficient in the night time. (Fig. S1).

A. Residential car parking areas of critical inquiry criteria AHP method.

A - Level of car ownerschip

A - Level of PT development

$\mathrm{A}^{2}$ - Density of populiation

$\mathrm{A}^{3}$ - Total area of the built-up territory

$A_{5}^{4}-$ Number of populiation

$A^{5}$ - Street density

$A_{7}^{6}-$ Number of workplaces

$\mathrm{A}_{8}^{7}$ - Number of employed people

B. The schopping centres car parking areas of critical inquiry AHP method.

$\mathrm{B}_{1}$ - Intensity of housing development

$\mathrm{B}_{2}$-Width of the carriageway of streets situated at the shopping centres

$\mathrm{B}_{3}$ - Number of flats

$\mathrm{B}_{4}-$ Value of flats

$\mathrm{B}_{5}$ - Direct visibility of the parking lot

from the surrounding flats

B - Working population

$\mathrm{B}_{7}^{6}$ - The demand for parking spaces

CRITERIAL SYSTEM OF CAR PARKING LOTS IN METROPOLITAN

C. System park and ride car parking areas of critical inquiry criteria AHP method

$\mathrm{C}_{1}$ - Construction cost of $\mathrm{P}+\mathrm{R}$ parking lot

$\mathrm{C}_{2}$ - Traffic volume

$\mathrm{C}_{3}$ - Public transport network development

$\mathrm{C}_{4}$ - Centre accessibility by public transport, speed

$\mathrm{C}_{5}$ - Safety of $\mathrm{P}+\mathrm{R}$ parking lot

$\mathrm{C}_{6}$ - Driver information system

$\mathrm{C}_{7}$ - Parking fee for a car in the parking lot

$\mathrm{C}_{8}$ - Is the entrance to the parking lot convenient?

$\mathrm{C}_{9}-$ Street category

$\mathrm{C}_{10}^{9}$ Integrated ticket fee for the parking and using PT

$\mathrm{C}_{11}$ - Housing intensity

Fig. S1. The scheme of the criteria system for car parking in cities 
In order to solve the temporary parking problem, an analysis of the park and ride parking lot development system possibilities is carried out. Based upon the decisions of the Vilnius city general plan, there are 33 preliminary park and ride system parking lot locations. Since the park and ride system does not exist in Lithuania, it is not possible to carry out constructive or developmental park and ride system parking lot analysis in the city based upon its criteria importance and its influence on efficiency by the means of strategic field and laboratory experiments. Therefore, multi-criteria methods are applied in order to achieve this goal.

Figure S2 presents a theoretical model of the park and ride parking lot system.

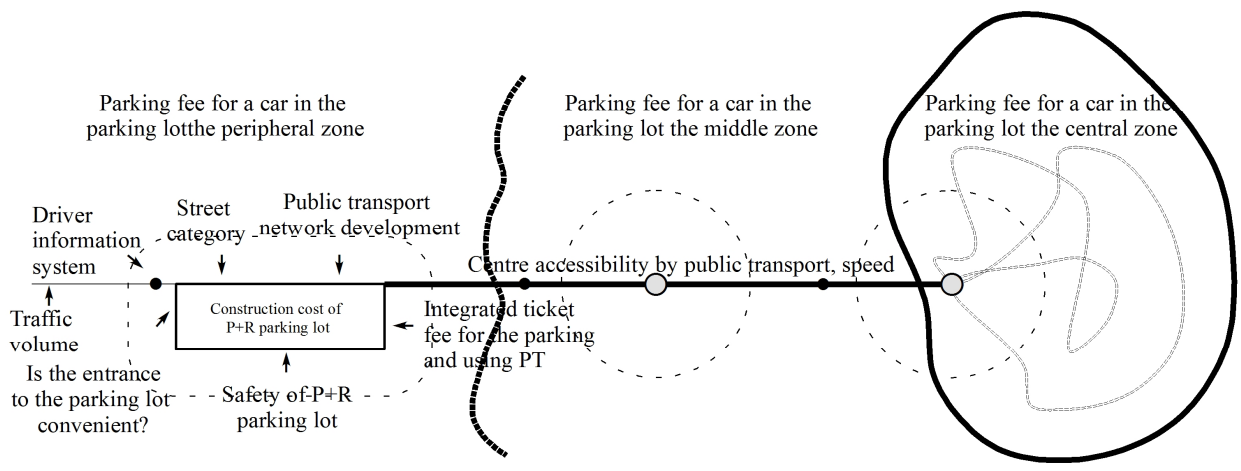

Fig. S2. Theoretical model of the park and ride system (made by the author)

The criteria for car parking in the city were determined by the examination method, i.e. the supervisor of the thesis together with the author of the thesis discerned and systematized the criteria. Appropriate survey questionnaires were given to specialists when applying the analytic hierarchy process (AHP) method. The survey was carried out in Vilnius City where transportation system and territory planning specialists were questioned.

The multi-criteria solutions for parking spaces in the city were applied to criteria groups (A, B and C) with the ranks and weight coefficients estimated by the experts; this allowed to establish the criteria priorities when choosing car parking spaces in city zones. It was found that the level of automobilization (0.287) and the level of public transport development $(0.214)$ has the biggest influence in group A; the demand for parking spaces $(0.3452)$ and the number of apartments $(0.2058)$ has the biggest influence in group B; the development level of the public transport system ( 0.157$)$ and the duration of a journey by public transport $(0.148)$ has the biggest influence in group $\mathrm{C}$. 


\section{The assessment of the effectiveness of the parking lots in city}

In the third section the 3 staged evaluation of the parking lots effectiveness in Vilnius is carried out. In the first stage priority queues are formed of residential areas of blocks of flats. The queue also denotes the best and the worst parking conditions. In the stage two, the evaluation of shopping center's parking lots effectiveness is carried out with the purpose to effectively use these lots for parking in the night time.

In the third stage, according to the decisions of the Vilnius city general plan, an analysis of the dislocation of 33 park and ride parking lots is carried out. According to the results of the research, and the weight rate of car parking lot criteria, the multifunctional methods such as COPRAS, SAW, TOPSIS and PROMETHEE are used to evaluate the car parking lots.

After the calculations of the first stage it is defined that the best conditions for car parks are in Justiniskes district and the worst - in Pilaites district. The reasons of such ranking are the following:

1. The level of motorisation in the residential area of blocks of flats. Statistically, we can state that the higher the motorisation level is the more intense need is for places in parking lots. In the process of research it is established that this index differed from 358.3 to 470.1 cars/1000 inh.

2. The level of the development of the public transport. The density of route, the frequency and speed of public transport shows the quality service in the city. There are more possibilities and a greater access to reach the destination in case of a higher index.

3. The number of inhabitant. It is a tendency for people to keep their cars as near to their home as possible, not further than $300 \mathrm{~m}$ from home. The need for places in parking lots in residential areas depends on people's age, social status, health, and the number of family members.

In the stage two, the complete diverse analysis of 49 parking lots in shopping centres was carried out. According to the density ratio in the night time, the lots were divided into 4 groups: The $1^{\text {st }}$ group lots were occupied from $76 \%$ to $100 \%$; the 2 nd $51 \%-75 \%$, the 3rd $-26 \%-50 \%$, and the 4 th $-0 \%-25 \%$. In order to gain unambiguous answer to what size parking lots in shopping centres are required to be established in residential areas and what are unwished, the following hypothesis was suggested and confirmed. In the urbanised territories, in the stage of planning residential areas and parking lots in shopping centres, a certain amount of inhabitants cars can be directed to the latter places.

The best results were achieved in evaluation of the shopping centres belong to the 1st group. These are not large shopping centres up to $2000 \mathrm{~m}^{2}$ which have approximately 100 car places (Table S1). It is advisory to build such shopping centres in the territories of blocks of flats which will allow to optimise the land for car parking in the night time. In order to achieve this, the limit values meanings have to be retained. These are the 
following: buildings intensity ( $U I$ ), not less than 1.00, the number of employees ( $D G_{s}$ ), not less than 2000 , the number of flats $\left(B_{s}\right)$, not less than 1000 . The calculations show that we can reach the density index of car parks $\left(P C_{k}\right)$ up to 1.00 and to safe $5.6 \%$ of land for car place $\left(P C_{r}\right)$ taken from each flat.

Table S1. The 4th shopping centres limit value

\begin{tabular}{ccccccc}
\hline \multirow{2}{*}{$\begin{array}{c}P C_{p}, \\
\mathrm{~m}^{2}\end{array}$} & $P C_{v}$ & $U I$ & $D G s$ & $P C_{k}$ & $P C_{r}$, \\
\cline { 3 - 6 } iki 2000 & iki 100 & $>1.00$ & $>2000$ & $>1800$ & 1.00 & 5.6 \\
\hline $2001-3000$ & $101-150$ & $0.7-1.00$ & $1500-1999$ & $1300-1799$ & 0.60 & 5.0 \\
\hline $3001-4000$ & $151-200$ & $0.3-0.7$ & $1200-1499$ & $1000-1299$ & 0.40 & - \\
\hline$>4001$ & $>201$ & $<0.3$ & $1000-1199$ & $800-999$ & 0.12 & - \\
\hline
\end{tabular}

The results of the 3rd place were gained in evaluating the 3rd group of shopping centres (3001-4000 $\mathrm{m}^{2}$ ) which have from 151 to 200 car places (Table S1). These parking lots are not effectively used by inhabitants in the night time. The density index $\left(P C_{k}\right)-0.4$. In the research of accessibility on foot, it was estimated that after people leave their cars in the shopping centres it takes up to 10 minutes to come home.

The results of the 4th place were obtained in evaluating the 4th group of the shopping centres (more than $4000 \mathrm{~m}^{2}$ which have more than 200 car places (Table S1). These shopping centres are typical for functions of businesses, entertainment, and special services, oriented to middle class and rich people. Their locations demonstrate the exceptionality: large parking lots, are often built intensely populated city districts, at the main transport hubs and important arterial roads. After the research it was stated that such parking lots are really used by inhabitants in the night time. For this reason, it is suggested to build such centres in the suburban areas of the city and accommodate them for park and ride system.

For all these groups mentioned, the meanings of limit values are founded. These meanings allow the evaluation of shopping centres parking lot development in the residential area of blocks of flats. They are established after the research of 49 parking lots in shopping centres with the applied multifunctional evaluation analysis.

In the stage 3, the evaluation of park and ride system is carried out according to the support of European Union of 2014-2020 period a sponsorship for five Lithuanian cities for development of park and ride system is planned. Vilnius city general plan informs that there are 33 preliminary park and ride system parking lot locations. These groups are divide into 3 groups according to the town zones. Lots in suburban areas of the city (he suburban, middle) and centre (Fig. S3).

Park and ride functions success depends on transport system integration to the city planning progress in which the questions of land property are solved, the financial sources and service needs are denoted; the possibilities to establish parking lots are restriced. 


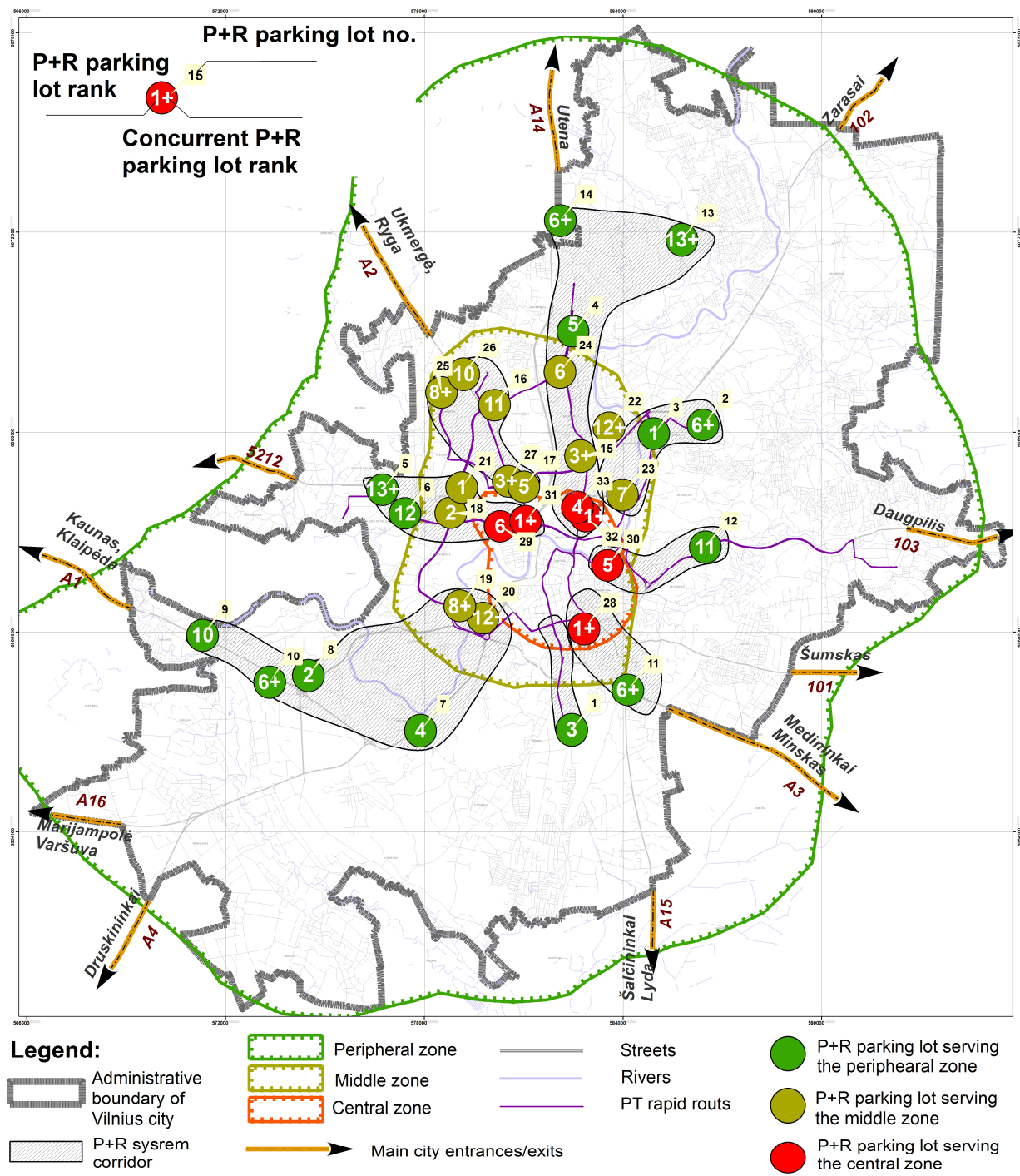

Fig. S3. The results of the systematic selection of Vilnius city park and ride parking lots calculated by multi-criteria methods

There were the reasons to propose the strategy of park and ride. Each park and ride lot is allotted to 8 main city entrances and exits (Fig. S3).

In order to evaluate with the same number linear center of attraction and it is infrastructure quality and adequacy for development of park and ride system's car parking's to help rationally manage car parking system, chemical pollution, traffic jams, accidents and improve quality of peoples lives mathematical model for calculating the index of park and ride system's car parking quality was proposed (Fig. S4). 


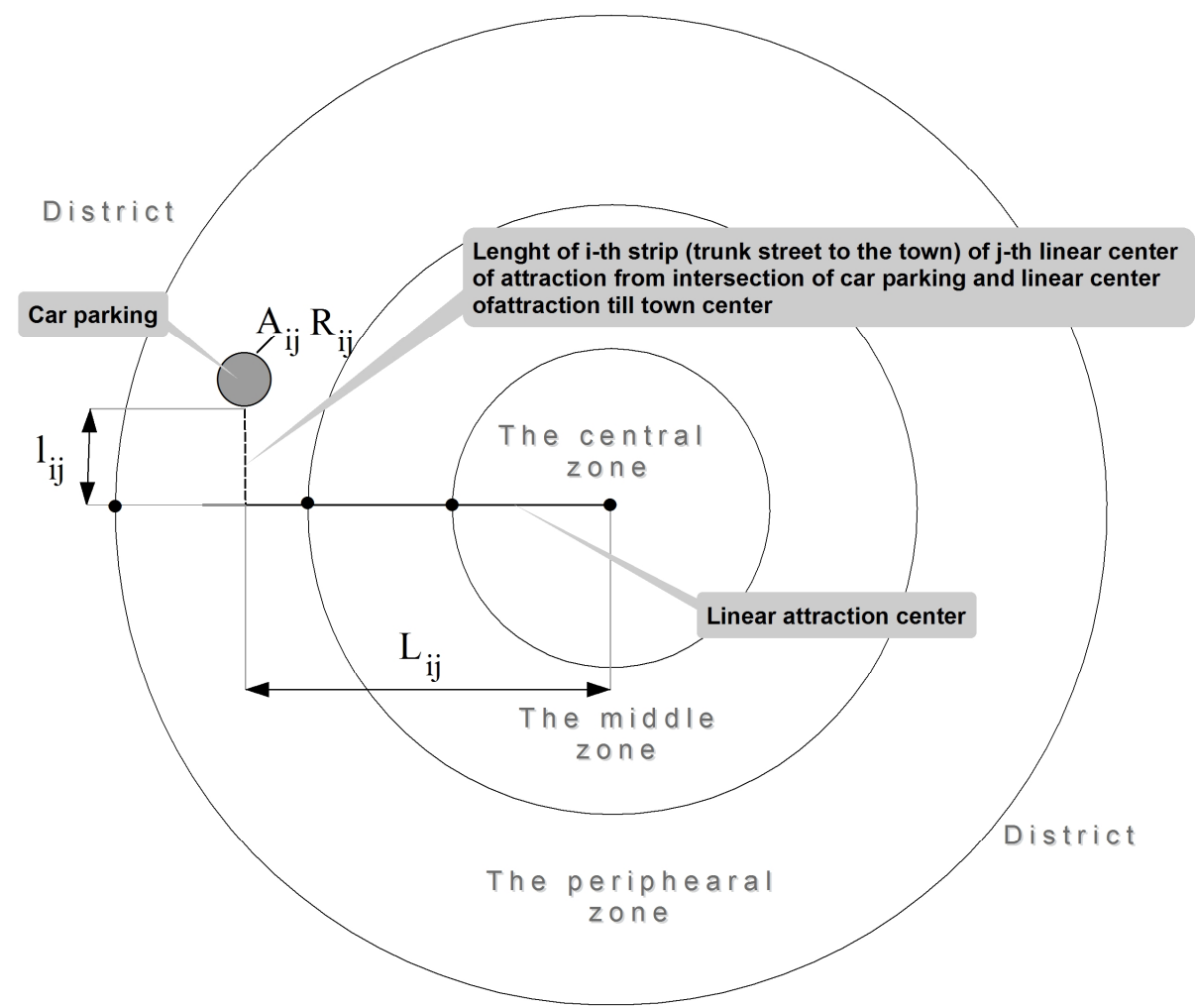

Fig. S4. Mathematical model of quality index calculation of Linear attraction center (author's)

After calculations, it is estimated that firstly, park and ride parking lots have to be established in service route in Kalvariju str. (Table S2). The route covers 3 park and ride parking lots.

Mathematical model being calculated according to the author's formula:

$$
K_{j}=\frac{\sum_{i=1}^{I} \frac{\left(L_{i j}-l_{i j}\right)^{2}}{A_{i j} \cdot R_{i j}}}{\frac{\sum_{j=1}^{J} I_{j}}{J} \cdot \sum_{j=1}^{J} \sum_{i=1}^{I} R_{i j}} .
$$

Here $K_{j}$ - quality index of linear center of attraction; $J$ - number of linear centers of attraction in town, $(j=1,2, \ldots, J) ; I$ - number of car parking's in $\mathrm{j}$-th route, in linear 
center of attraction, $(i=1,2, \ldots, I) ; K$ - number of car parking's in town, in all linear centers of attraction, $(k=1,2, \ldots, K), K=\sum_{j=1}^{J} I_{j} ; R$ - rank of car parking established by experts using multipurpose methods, $\left.R_{i j}=R_{1}+R_{2}+\ldots+R_{K}\right) ; R_{i j}$-rank of i-th car parking of i-th linear center of attraction, $(i=1,2, \ldots, I ; j=1,2, \ldots, J) ; A_{i j}$ - area of car parking; $L_{i j}$ - lenght of $\mathrm{i}$-th strip (trunk street to the town) of $\mathrm{j}$-th linear center of attraction from intersection of car parking and linear center of attraction till town center; $l_{i j}$ - distance from car parking till linear center of attraction.

Table S2. Park and ride system on parking lots calculated results

\begin{tabular}{|c|c|c|c|c|c|c|c|}
\hline $\begin{array}{c}\text { Linear center } \\
\text { of gravity }\end{array}$ & Parking no. & $L_{i j}, \mathrm{~m}$ & $l_{i j}, \mathrm{~m}$ & $\begin{array}{r}R_{i j}, \\
\text { rank }\end{array}$ & $A_{i j}, \mathrm{~m}^{2}$ & $K_{j}$ & Place \\
\hline \multirow{6}{*}{ A1 } & 1 parking & 13300 & 8300 & 10 & 25495 & \multirow{6}{*}{0.45} & \multirow{6}{*}{3} \\
\hline & 2 parking & 11200 & 6200 & 6 & 25495 & & \\
\hline & 3 parking & 9400 & 5000 & 2 & 25495 & & \\
\hline & 4 parking & 7500 & 300 & 4 & 25495 & & \\
\hline & 5 parking & 4100 & 300 & 8 & 10926 & & \\
\hline & 6 parking & 3500 & 600 & 12 & 10926 & & \\
\hline \multirow{6}{*}{5212} & 1 parking & 7100 & 300 & 13 & 25495 & \multirow{6}{*}{0.65} & \multirow{6}{*}{2} \\
\hline & 2 parking & 6100 & 100 & 12 & 25495 & & \\
\hline & 3 parking & 4800 & 500 & 2 & 25495 & & \\
\hline & 4 parking & 6000 & 1200 & 1 & 25495 & & \\
\hline & 5 parking & 3000 & 100 & 6 & 10926 & & \\
\hline & 6 parking & 2100 & 100 & 1 & 10926 & & \\
\hline \multirow{5}{*}{ A2 } & 1 parking & 7300 & 700 & 10 & 10926 & \multirow{5}{*}{0.44} & \multirow{5}{*}{4} \\
\hline & 2 parking & 7000 & 300 & 8 & 10926 & & \\
\hline & 3 parking & 5700 & 500 & 11 & 10926 & & \\
\hline & 4 parking & 3500 & 300 & 3 & 10926 & & \\
\hline & 5 parking & 3400 & 300 & 5 & 10926 & & \\
\hline \multirow{8}{*}{ A14 } & 1 parking & 10100 & 2100 & 6 & 25495 & \multirow{8}{*}{$1.13^{*}$} & \multirow{8}{*}{1} \\
\hline & 2 parking & 10500 & 4300 & 13 & 25495 & & \\
\hline & 3 parking & 7000 & 100 & 5 & 25495 & & \\
\hline & 4 parking & 6000 & 500 & 6 & 10926 & & \\
\hline & 5 parking & 4700 & 500 & 3 & 10926 & & \\
\hline & 6 parking & 4500 & 800 & 12 & 10926 & & \\
\hline & 7 parking & 1400 & 100 & 4 & 3237 & & \\
\hline & 8 parking & 1300 & 100 & 1 & 3237 & & \\
\hline
\end{tabular}


End of the Table $S 2$

\begin{tabular}{cccccccc}
\hline \multirow{2}{*}{102} & 1 parking & 6500 & 300 & 6 & 25495 & & \\
& 2 parking & 5900 & 100 & 1 & 25495 & 0.28 & 5 \\
& 3 parking & 3600 & 300 & 7 & 10926 & & \\
\hline \multirow{2}{*}{103} & 1 parking & 4600 & 100 & 11 & 25495 & 0.02 & 8 \\
& 2 parking & 1200 & 100 & 5 & 3237 & & \\
\hline \multirow{2}{*}{ A3 } & 1 parking & 4600 & 2000 & 6 & 25495 & \multirow{2}{*}{0.15} & 6 \\
\hline Airport & 2 parking & 2200 & 100 & 1 & 3237 & & \\
\hline
\end{tabular}

The last section of the dissertation provides three original conceptual models of park and ride parking lots which are accommodated to an actual city space.

\section{General conclusions}

1. The analysis of the research of scientific literature on parking lots showed that rapidly growing motorisation level is altering into systematic city crisis: constant traffic congestion, the time extension of daily trips, traffic quality, the increase of public transport speed, and etc. According to the experiences of foreign countries, there are a lot of cities which managed to partially solve some occurring problems ith car parking lots in urbanised territories.

2. AHP method was applied to denote the weight criteria of the answers to the questionnaire given to the experts of each group $\mathrm{A}, \mathrm{B}$, and $\mathrm{C}$. The importance of group criteria have been defined, and the opinions proportionated.

3. Car parking lots research in 8 Vilnius residential areas of blocks of flats show that the problem exists not only in the areas which were constructed in the times of the Soviet Union when according to the criteria one car space was allotted to 4-5 flats, but also it exists in recently built residential areas, where a parking space is allotted to each fact. The research shows that $2.2 \%-18.4 \%$ of cars, parked in residential areas in the night time, are parked in violation of the road traffic regulations.

4. It is estimated that the density of parking lots in the night time vary from the numbers of flats, employees, and etc.

5. The best results were in evaluating the 1st group of parking lots in those shopping centres which while planning the buildings allows the flow of car into their territory. The second place results are based on evaluation of the II group of parking lots in shopping centres and it the development of new blocks of flats, it is important to find the right positioning of the elements of between the two.

6. After carrying out the analysis of park and ride parking lots and multifunctional evaluation in the suburban the ratio, the priority queue must be established. According to the ranking results, the systematic strategy of selection allows certain calculations of the most rational routes. 
7. The conceptual methods of park and ride car lotuses are created and adjusted to the conditions of Vilnius. All is taken into consideration: free land, street facility, traffic safety and public transport routes. The models can be applied to other cities which will create possibilities for successful functioning of park and ride parking lots. 
A priedas. Sprendimo prièmimo duomenys, automobilių stovejjimo vietų prekybos centruose, daugiatiksliam vertinimui

B priedas. Bendraautorių sutikimai teikti publikacijoje skelbtą medžiagą mokslo daktaro disertacijoje

C priedas. Autoriaus mokslinių publikacijų disertacijos tema kopijos

*Priedai pateikiami pridètoje kompaktinèje plokštelèje 


\section{A priedas. Sprendimo prièmimo duomenys, automobilių stovejjimo vietų prekybos centruose, daugiatiksliam vertinimui}

A1 lentelè. I-osios grupès prekybos centrų automobilių stovejjimo aikštelių kriterijų reikšmès

Table A1. The values of the criteria of occupancy potential for car parking's of shopping centres in group I

\begin{tabular}{ccccccccc} 
Eil. & $\begin{array}{l}\text { PC pavadinimas } \\
\text { Nr. }\end{array}$ & $\begin{array}{c}\mathrm{B}_{1}, \\
\%\end{array}$ & $\begin{array}{c}\mathrm{B}_{2}, \\
\mathrm{~m}\end{array}$ & $\begin{array}{c}\mathrm{B}_{3}, \\
\text { vnt. }\end{array}$ & $\begin{array}{c}\mathrm{B}_{4}, \\
\text { Lt./m }\end{array}$ & $\begin{array}{c}\mathrm{B}_{5}, \\
\%\end{array}$ & $\begin{array}{c}\mathrm{B}_{6}, \\
\text { vnt. }\end{array}$ & $\begin{array}{c}\mathrm{B}_{7} \\
\%\end{array}$ \\
\hline 1. & PC „Iki“ (Laisvès pr. 31) & 1,36 & 34 & 2480 & 2670 & 17 & 2350 & 239 \\
\hline 2. & $\begin{array}{l}\text { PC „Iki“ } \\
\text { (Didlaukio g. 80A) }\end{array}$ & 0,95 & 70 & 1610 & 3448 & 11 & 1880 & 505 \\
\hline 3. & $\begin{array}{l}\text { PC „Rimi“ } \\
\text { (L. Asanavičiūtès g. 20) }\end{array}$ & 0,79 & 6 & 1430 & 2670 & 17 & 1350 & 241 \\
\hline 4. & PC „Iki“ (Rygos g. 41) & 1,48 & 24 & 2480 & 2734 & 14 & 3150 & 259 \\
\hline 5. & PC „Iki“(Žemynos g. 2) & 1,08 & 14 & 1720 & 2705 & 18 & 2470 & 542 \\
\hline 6. & $\begin{array}{l}\text { PC „Maxima“ } \\
\text { (Didlaukio g. 1) }\end{array}$ & 0,42 & 13 & 720 & 3402 & 9 & 960 & 492 \\
\hline 7. & $\begin{array}{l}\text { PC „Iki“ } \\
\text { (Antakalnio g. 73) }\end{array}$ & 1,03 & 14 & 2220 & 3489 & 10 & 1780 & 373 \\
\hline 8. & $\begin{array}{l}\text { PC „Maxima“ } \\
\text { (Taikos g. 162A) }\end{array}$ & 1,01 & 20 & 1700 & 2730 & 19 & 2240 & 256 \\
\hline
\end{tabular}

A2 lentelė. II-osios grupès prekybos centrų automobilių stovèjimo aikštelių kriterijų reikšmès

Table A2. The values of the criteria of occupancy potential for car parking's of shopping centres in group II

\begin{tabular}{clccccccc} 
Eil. & $\begin{array}{l}\text { PC pavadinimas } \\
\text { Nr. }\end{array}$ & $\begin{array}{c}\mathrm{B}_{1}, \\
\%\end{array}$ & $\begin{array}{c}\mathrm{B}_{2}, \\
\mathrm{~m}\end{array}$ & $\begin{array}{c}\mathrm{B}_{3}, \\
\text { vnt. }\end{array}$ & $\begin{array}{c}\mathrm{B}_{4}, \\
\text { Lt./m }\end{array}$ & $\begin{array}{c}\mathrm{B}_{5}, \\
\%\end{array}$ & $\begin{array}{c}\mathrm{B}_{6}, \\
\text { vnt. }\end{array}$ & $\begin{array}{c}\mathrm{B}_{7}, \\
\%\end{array}$ \\
\hline 1. & $\begin{array}{l}\text { PC „Rimi“ } \\
\text { (Architektų g. 19) }\end{array}$ & 0,92 & 14 & 1610 & 2635 & 17 & 1580 & 369 \\
\hline 2. & $\begin{array}{l}\text { PC „Maxima“ } \\
\text { (Gedvydžių g. 17) }\end{array}$ & 1,03 & 13 & 1640 & 2757 & 9 & 2310 & 255 \\
\hline 3. & $\begin{array}{l}\text { PC „Norfa“ } \\
\text { (Laisvès pr. 82) }\end{array}$ & 0,53 & 40 & 950 & 2738 & 6 & 1250 & 467 \\
\hline 4. & $\begin{array}{l}\text { PC „Rimi“ } \\
\text { (Antakalnio g. 85) }\end{array}$ & 0,63 & 14 & 1320 & 3448 & 3 & 1060 & 390 \\
\hline 5. & $\begin{array}{l}\text { PC „Maxima“ } \\
\text { (Šaltkalvių g. 2) }\end{array}$ & 0,96 & 34 & 1760 & 2659 & 11 & 1750 & 455 \\
\hline
\end{tabular}


A2 lentelès pabaiga

\begin{tabular}{clccccccc} 
6. & $\begin{array}{l}\text { PC „Iki““ } \\
\text { (Saulètekio al. 43) }\end{array}$ & 0,13 & 7 & 20 & 2635 & 0 & 140 & 221 \\
\hline 7. & $\begin{array}{l}\text { PC „Norfa“ } \\
\text { (Savanoriu pr. 1) }\end{array}$ & 0,33 & 30 & 590 & 4151 & 40 & 690 & 463 \\
\hline 8. & $\begin{array}{l}\text { PC „BIG“ } \\
\text { (Ukmergès g. 369) }\end{array}$ & 0,73 & 33 & 1290 & 3837 & 0 & 1710 & 221 \\
\hline
\end{tabular}

A3 lentelè. III-osios grupės prekybos centrų automobilių stovejimo aikštelių kriterijų reikšmès

Table A3. The values of the criteria of occupancy potential for car parking's of shopping centres in group III

\begin{tabular}{|c|c|c|c|c|c|c|c|c|}
\hline $\begin{array}{l}\text { Eil. } \\
\text { Nr. }\end{array}$ & $\begin{array}{l}\text { PC pavadinimas } \\
\text { (adresas) }\end{array}$ & $\begin{array}{c}\mathrm{B}_{1}, \\
\%\end{array}$ & $\begin{array}{c}\mathrm{B}_{2}, \\
\mathrm{~m}\end{array}$ & $\begin{array}{l}\mathrm{B}_{3}, \\
\text { vnt. }\end{array}$ & $\begin{array}{l}\mathrm{B}_{4} \\
\mathrm{Lt} . / \mathrm{m}^{2}\end{array}$ & $\begin{array}{c}\mathrm{B}_{5}, \\
\%\end{array}$ & $\begin{array}{l}\mathrm{B}_{6}, \\
\text { vnt. }\end{array}$ & $\begin{array}{c}\mathrm{B}_{7}, \\
\%\end{array}$ \\
\hline 1. & $\begin{array}{l}\text { PC „Norfa“ } \\
\text { (Ateities g. 48) }\end{array}$ & 0,43 & 8 & 680 & 2949 & 5 & 970 & 260 \\
\hline 2. & $\begin{array}{l}\text { PC „Mandarinas“ } \\
\text { (Ateities g. 91) }\end{array}$ & 0,35 & 10 & 520 & 3267 & 30 & 830 & 282 \\
\hline 3. & $\begin{array}{l}\text { PC „Norfa“ } \\
\text { (L. Zemanhofo g. 3) }\end{array}$ & 0,76 & 6 & 1290 & 3463 & 0 & 1770 & 234 \\
\hline 4. & PC „Iki“ (Žirmūnų g. 2) & 0,70 & 0 & 1390 & 3474 & 8 & 1220 & 417 \\
\hline 5. & $\begin{array}{l}\text { PC „Iki“ } \\
\text { (Buivydiškių g. 17) }\end{array}$ & 0,77 & 35 & 1330 & 2696 & 9 & 1510 & 249 \\
\hline 6. & $\begin{array}{l}\text { PC „Maxima““ } \\
\text { (Viršuliškių g. 30) }\end{array}$ & 1,04 & 7 & 1880 & 2710 & 15 & 1890 & 169 \\
\hline 7. & $\begin{array}{l}\text { PC „Maxima“ } \\
\text { (Mindaugo g. 11) }\end{array}$ & 0,55 & 27 & 1020 & 3779 & 11 & 1140 & 446 \\
\hline 8. & $\begin{array}{l}\text { PC „Iki“ } \\
\text { (Antakalnio g. 42) }\end{array}$ & 0,35 & 14 & 730 & 3345 & 0 & 630 & 390 \\
\hline 9. & $\begin{array}{l}\text { PC „Iki“ } \\
\text { (Architektų g. 214) }\end{array}$ & 0,64 & 15 & 1150 & 2614 & 19 & 1070 & 352 \\
\hline 10. & PC „Iki“ (Kapsų g. 22) & 0,45 & 7 & 770 & 2659 & 11 & 920 & 491 \\
\hline 11. & $\begin{array}{l}\text { PC „Norfa“ } \\
\text { (Justiniškių g. 12) }\end{array}$ & 0,28 & 27 & 480 & 2730 & 22 & 570 & 187 \\
\hline 12 & $\begin{array}{l}\text { PC „Rimi“ } \\
\text { (Antakalnio g. 55/1) }\end{array}$ & 0,71 & 21 & 1410 & 3345 & 8 & 1170 & 414 \\
\hline 13. & $\begin{array}{l}\text { PC „Norfa“" } \\
\text { (L. Asanavičiūtès g. 29) }\end{array}$ & 0,82 & 66 & 1530 & 2670 & 31 & 1400 & 233 \\
\hline
\end{tabular}


A4 lentelè. IV-osios grupès prekybos centrų automobilių stovėjimo aikštelių kriterijų reikšmès

Table A4. The values of the criteria of occupancy potential for car parking's of shopping centres in group IV

\begin{tabular}{|c|c|c|c|c|c|c|c|c|}
\hline $\begin{array}{l}\text { Eil. } \\
\text { Nr. }\end{array}$ & $\begin{array}{l}\text { PC pavadinimas } \\
\text { (adresas) }\end{array}$ & $\begin{array}{c}\mathrm{B}_{1}, \\
\%\end{array}$ & $\begin{array}{c}\mathrm{B}_{2}, \\
\mathrm{~m}\end{array}$ & $\begin{array}{l}\mathrm{B}_{3}, \\
\text { vnt. }\end{array}$ & $\begin{array}{l}\mathrm{B}_{4}, \\
\text { Lt. } / \mathrm{m}^{2}\end{array}$ & $\begin{array}{c}\mathrm{B}_{5}, \\
\%\end{array}$ & $\begin{array}{l}\mathrm{B}_{6}, \\
\text { vnt. }\end{array}$ & $\begin{array}{c}\mathrm{B}_{7}, \\
\%\end{array}$ \\
\hline 1. & $\begin{array}{l}\text { PC ,Rimi“ } \\
\text { (Kareivių g. 11A) }\end{array}$ & 0,17 & 0 & 310 & 3345 & 25 & 400 & 458 \\
\hline 2. & $\begin{array}{l}\text { PC ,Norfa“ } \\
\text { (Justiniškių g. 91) }\end{array}$ & 0,95 & 48 & 1590 & 2721 & 0 & 2050 & 258 \\
\hline 3. & $\begin{array}{l}\text { PC ,Maxima“" } \\
\text { (Gabijos g. 30) }\end{array}$ & 0,72 & 16 & 1170 & 3219 & 14 & 1530 & 526 \\
\hline 4. & $\begin{array}{l}\text { PC „Maxima“ } \\
\text { (Žalgirio g. 105) }\end{array}$ & 0,49 & 23 & 870 & 3631 & 12 & 1030 & 475 \\
\hline 5. & $\begin{array}{l}\text { PC „Rimi““ } \\
\text { (Savanoriu pr. 16) }\end{array}$ & 0,21 & 40 & 410 & 3527 & 25 & 470 & 432 \\
\hline 6. & PC „Iki“ (Š́eškinės g. 32) & 0,33 & 50 & 590 & 2735 & 8 & 630 & 170 \\
\hline 7. & $\begin{array}{l}\text { PC „Mada“ } \\
\text { (Viršuliškių g. 40) }\end{array}$ & 0,89 & 15 & 1580 & 2690 & 20 & 1800 & 238 \\
\hline 8. & $\begin{array}{l}\text { PC „Iki“، } \\
\text { (Fabijoniškių g. 2A) }\end{array}$ & 0,27 & 9 & 450 & 2782 & 8 & 650 & 243 \\
\hline 9. & $\begin{array}{l}\text { PC „Banginis“ } \\
\text { (P. Lukšio g. 34) }\end{array}$ & 0,61 & 21 & 1170 & 3345 & 14 & 1450 & 105 \\
\hline 10. & $\begin{array}{l}\text { PC ,Norfa“ (Ateities g. } \\
10)\end{array}$ & 0,44 & 22 & 700 & 3097 & 18 & 920 & 540 \\
\hline 11. & $\begin{array}{l}\text { PC „Rimi“ (P. Lukšio g. } \\
64)\end{array}$ & 0,29 & 39 & 580 & 3345 & 50 & 590 & 419 \\
\hline 12. & $\begin{array}{l}\text { PC „Rimi“ (Jeruzalès g. } \\
\text { 4) }\end{array}$ & 0,67 & 20 & 1140 & 4212 & 3 & 1530 & 496 \\
\hline 13. & $\begin{array}{l}\text { PC „Maxima“ } \\
\text { (Liepkalnio g. 122) }\end{array}$ & 0,04 & 42 & 70 & 1666 & 0 & 90 & 543 \\
\hline 14. & $\begin{array}{l}\text { PC „Maxima“ } \\
\text { (Ukmergès g. 282) }\end{array}$ & 0,34 & 42 & 570 & 3413 & 9 & 810 & 516 \\
\hline 15. & $\begin{array}{l}\text { PC „Iki““ } \\
\text { (J. Jasinskio g. 16) }\end{array}$ & 0,17 & 52 & 180 & 4190 & 0 & 280 & 847 \\
\hline 16. & $\begin{array}{l}\text { PC „Maxima“ } \\
\text { (Tuskulėnų g. 66) }\end{array}$ & 1,04 & 18 & 2000 & 3307 & 14 & 1900 & 433 \\
\hline 17. & $\begin{array}{l}\text { PC „Norfa“" } \\
\text { (Kalvarijų g. 206) }\end{array}$ & 0,13 & 0 & 220 & 3135 & 0 & 280 & 493 \\
\hline
\end{tabular}




\begin{tabular}{rlrrrrrrr} 
& & \multicolumn{5}{c}{ A4 lentelés pabaiga } \\
\hline 18. & PC „Iki“ (Jeruzalès g. 17) & 0,34 & 22 & 540 & 3283 & 23 & 780 & 541 \\
\hline 19. & $\begin{array}{l}\text { PC „Norfa“ } \\
\text { (L. Giros g. 15) }\end{array}$ & 0,53 & 11 & 840 & 2962 & 8 & 1320 & 260 \\
\hline 20. & $\begin{array}{l}\text { PC „Maxima“ } \\
\text { (Sausio 13-osios g. 2) }\end{array}$ & 0,28 & 18 & 540 & 2670 & 0 & 480 & 222 \\
\hline
\end{tabular}


Vytautas PALEVIČIUS

LENGVŲJŲ AUTOMOBILIŲ STOVĖJIMO AIKŠTELIŲ MIESTE VERTINIMAS DAUGIATIKSLIAIS METODAIS

\section{Daktaro disertacija}

Technologijos mokslai, statybos inžinerija (02T)

EVALUATION OF CAR PARKING LOTS IN CITIES BY MULTICRITERIA METHODS

Doctoral Dissertation

Technological Sciences,

Civil Engineering (02T) 